$$
\begin{aligned}
& \text { UNIVERSITY OF SÃO PAULO } \\
& \text { INSTITUTE OF GEOSCIENCES }
\end{aligned}
$$

\title{
NUMERICAL GROUNDWATER FLOW MODELING APPLIED TO DEWATERING PREDICTION OF CAUÊ AQUIFER IN ALEGRIA MINE, EAST OF QUADRILÁTERO FERRÍFERO, MINAS GERAIS
}

\author{
João Paulo Chiste Costa
}

Supervisor: DSc. Alexandra Vieira Suhogusoff

\author{
MASTER THESIS \\ Mineral Resources and Hydrogeology Graduate Program \\ Corrected Version
}




$$
\begin{aligned}
& \text { UNIVERSIDADE DE SÃO PAULO } \\
& \text { INSTITUTO DE GEOCIÊNCIAS }
\end{aligned}
$$

\section{NUMERICAL GROUNDWATER FLOW MODELING APPLIED TO DEWATERING PREDICTION OF CAUÊ AQUIFER IN ALEGRIA MINE, EAST OF QUADRILÁTERO FERRÍFERO, MINAS GERAIS}

\section{JOÃO PAULO CHISTE COSTA}

Orientadora: Profa. Dra. Alexandra Vieira Suhogusoff

Dissertação de Mestrado

№ 844

COMISSÃO JULGADORA

Dra. Alexandra Vieira Suhogusoff

Dr. Nilson Guiguer Junior

Dr. Edson Cezar Wendland

Dra. Claudia Luciana Varnier

SÃO PAULO

2017 
Autorizo a reprodução e divulgação total ou parcial deste trabalho, por qualquer meio convencional ou eletrônico, para fins de estudo e pesquisa, desde que citada a fonte.

Serviço de Biblioteca e Documentação do IGc/USP

Ficha catalográfica gerada automaticamente com dados fornecidos pelo(a) autor(a) via programa desenvolvido pela Seção Técnica de Informática do ICMC/USP

Bibliotecários responsáveis pela estrutura de catalogação da publicação: Sonia Regina Yole Guerra - CRB-8/4208 | Anderson de Santana - CRB-8/6658

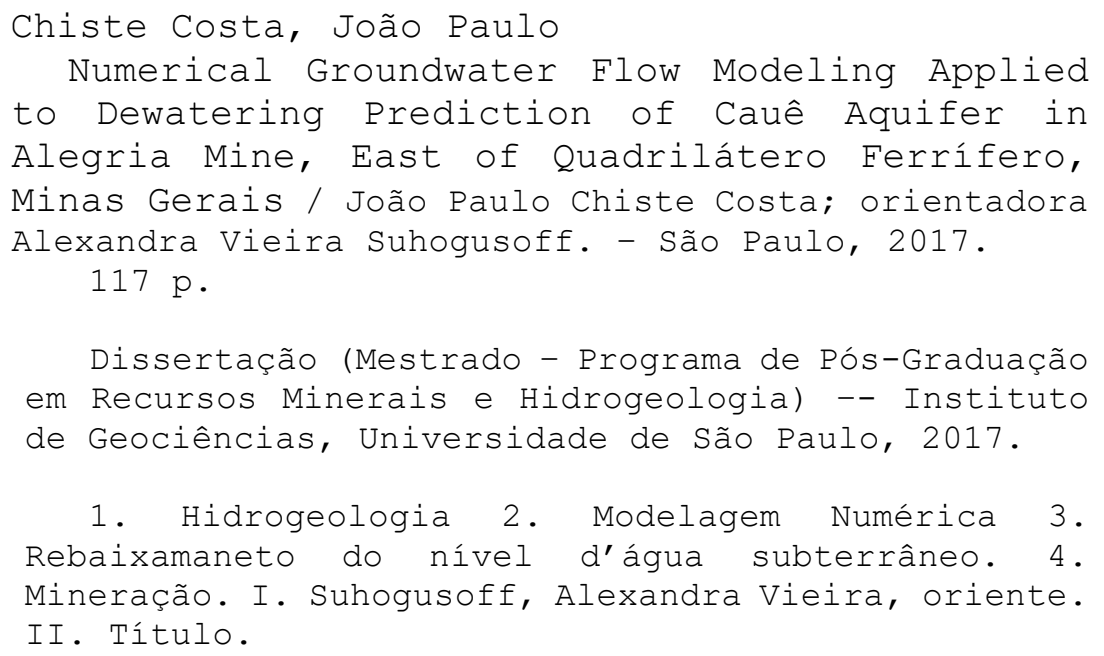


To my lovely wife Lucinéia 
"And let your rod be lifted up and your hand stretched out over the sea, and it will be parted in two; and the children of Israel will go through on dry land."

Exodus 14:16

"E tu, levanta o teu cajado, estende a mão sobre o mar e divide-o, para que os filhos de Israel atravessem o mar caminhando sobre o chão seco." Êxodo $14: 16$ 


\section{Acknowledgments / Agradecimentos}

A todos os meus familiares e amigos, especialmente aos meus pais, Paulo e Vânia, por me terem dado educação, amor e valores.

À minha esposa Lucinéia pelo apoio, carinho e pela compreensão nos momentos de ausência. Aos meus sogros, Sebastião e Lucia, e ao meu cunhado Lucas, pelo incentivo constante.

À Prof. ${ }^{a}$ Dr. ${ }^{\underline{a}}$ Alexandra (USP), minha orientadora, pelos ensinamentos e pela confiança. Ao consultor Prof. Dr. Luiz Ferrari, pela parceria e apoio dispensados em todos os momentos do mestrado. Vocês são meus exemplos de dedicação e amor à profissão acadêmica.

Aos professores, funcionários e colegas da USP, pelo aprendizado e por tornar essa jornada mais leve.

Aos amigos da Samarco Samuel, Leonardo, Rafael, Junia Rocha, Diego, Eduardo, Ronaldo, Enderson, Sandro e todos os que fazem ou fizeram parte da minha jornada.

Ao apoio incondicional da Samarco em acreditar na minha capacidade, em especial ao Wagner Milagres e Cesar Alves pela confiança e encorajamento na busca pelo sonho de me tornar mestre, nesta instituição.

Com vocês, divido a alegria desta experiência, ciente de que sozinho não seria possível à concretização desse sonho. 


\section{Abstract}

The feasibility to achieve a water table drawdown is one of realities of Quadrilátero Ferrífero District. In general, iron ore reserves are located in Cauê Formation, same geological unit of main aquifer of the region, that increasing complexity to acess ore reserve below piezometric level. Alegria Mine, located in east of Quadrilátero Ferrífero, is an example of a mining operation that, in order to be deepened, will need to be dewatering, which should occur gradually over the years. This study has the objective to perform conceptual and numerical groundwater flow models to simulate flow rate and number of pumping wells to achieve the drawdown necessary to acess the ore reserve, according an hyphotetical Samarco's mine planning schedule. Simulated model indicates that 98 pumping wells should be installed to access the ore reserve, which will be distributed in Alegria North, Alegria Center and Alegria South. The peak flow will be in order of $11,400 \mathrm{~m}^{3} / \mathrm{h}$. It was also simulated the efficiency of cut-off walls system in reducing leakage from Piracicaba River flow-rate to aquifer, under an extensive cone of depression. Eventual reduction of base-flow was calculated in the model that allowed planning the flow-rate to be returned to Piracicaba River and tributaries in order to preserve historical flows. The proposed structures for dewatering program will be jointly evaluated in the hydrogeological model in order to maintain sustainability of project with minimum environmental impact of the Piracicaba river.

Key-words: Dewatering, Quadrilátero Ferrífero, Cauê Aquifer, Mine, Groundwater Modeling, Pumping wells, Cut-off walls 
A viabilidade das estratégias para se alcançar o rebaixamento do nível d'água é uma das realidades das minas do Quadrilátero Ferrífero. Nesta região, em geral, as reservas de minério de ferro localizam-se na Formação Cauê, mesma unidade geológica do principal aquífero da região, aumentando a complexidade de viabilizar a operação da lavra abaixo do nível piezométrico. A Mina de Alegria, leste do Quadrilátero Ferrífero, é um exemplo de operação de lavra que para ser aprofundada necessitará do rebaixamento de nível d'água, o que deverá ocorrer gradativamente ao longo dos anos. Diante dessa realidade, este projeto tem por objetivo realizar os modelos hidrogeológicos conceitual e numérico de fluxo de águas subterrâneas, para testar de forma acurada a vazão requerida e o número de poços para se atingir o rebaixamento indicado pelos cenários hipotéticos de topografias sequenciadas das futuras cavas da Samarco Mineração. 0 modelo numérico indica que para acessar a reserva de minério deverão ser instalados 98 poços, os quais serão distribuídos nas minas de Alegria Norte, Alegria Centro e Alegria Sul. A vazão de pico será na ordem de 11,400 m³/h para viabilizar a reserva de minério neste cenário. Em conjunto com os poços, métodos de contenção do fluxo de água subterrânea (cut-off walls) foram testados nas simulações de rebaixamento, com vistas a reduzir os impactos na vazão do rio Piracicaba. Além de prever o comportamento hidráulico, sob as condições de um rebaixamento, por períodos prolongados, o modelo hidrogeológico pode simular os possíveis impactos hídricos e prever ações mitigadoras na sub-bacia do rio Piracicaba. A eventual redução do fluxo de base calculado no modelo possibilitou quantificar o volume de água que deverá ser restituído ao rio Piracicaba e afluentes de forma a preservar suas vazões históricas. As estruturas simuladas para o programa de rebaixamento do nível d'água foram avaliadas conjuntamente no modelo hidrogeológico, de forma a manter a sustentabilidade do empreendimento, com o mínimo impacto ambiental da sub-bacia do rio Piracicaba.

Palavras-chave: Rebaixamento de nível d'água, Mina, Quadrilátero Ferrífero, Aquífero Cauê, Modelagem Numérica de Fluxo Subterrâneo, Poços de Rebaixamento, Cut-off Walls 


\section{SUMMARY}

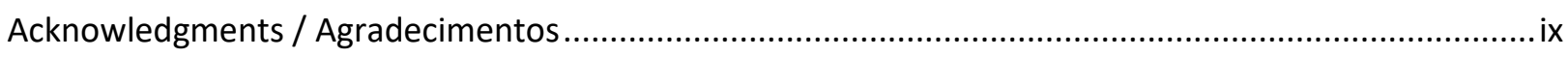

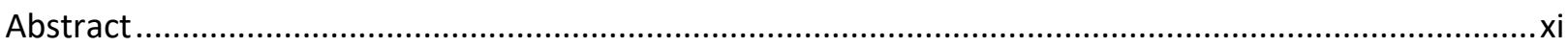

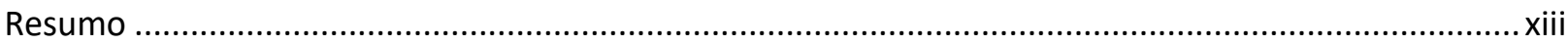

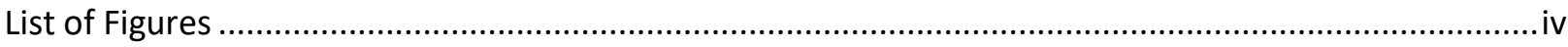

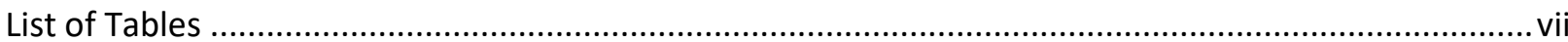

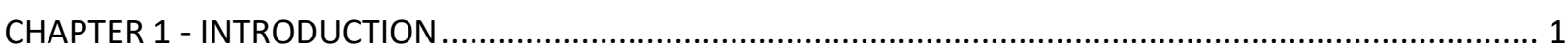

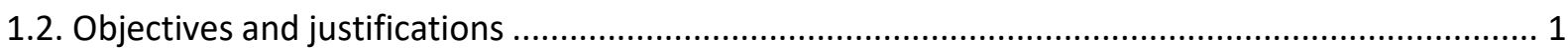

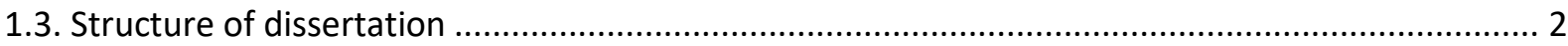

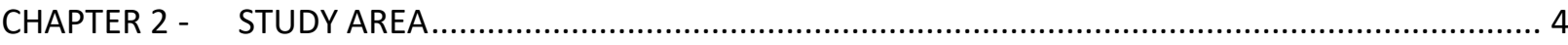

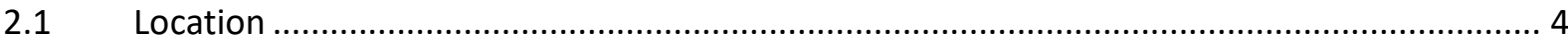

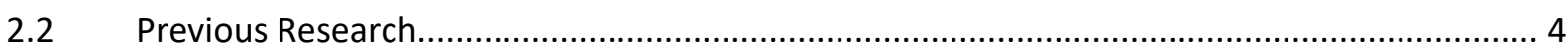

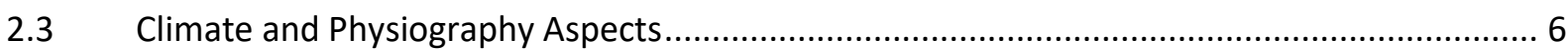

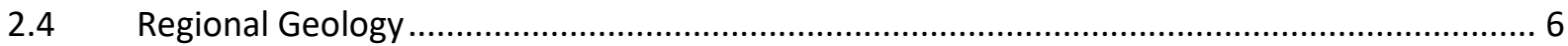

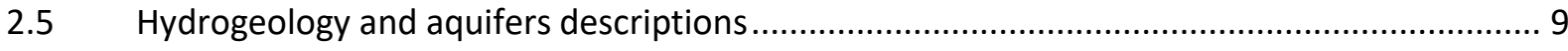

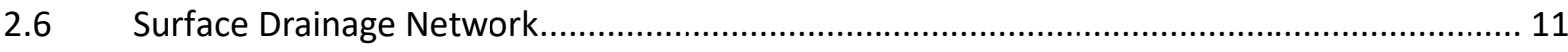

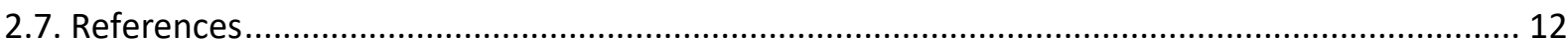

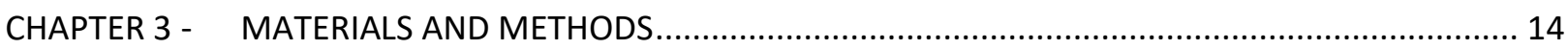

3.1. Conceptual Geological and Hydrogeological Model ................................................................. 14

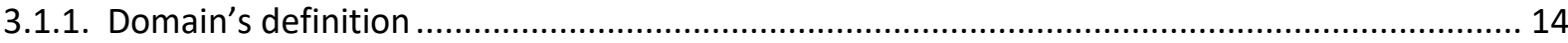

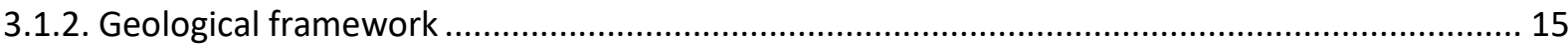

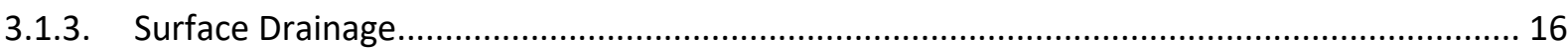

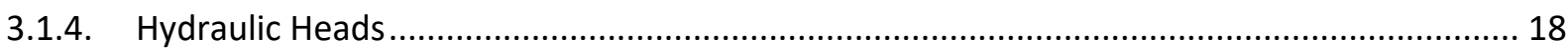

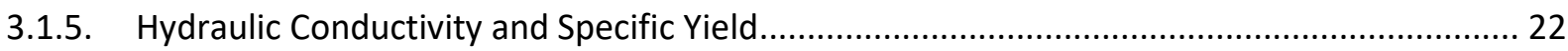

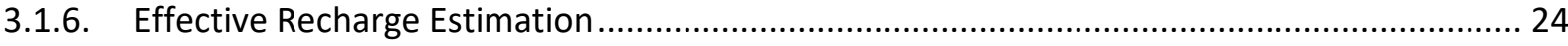

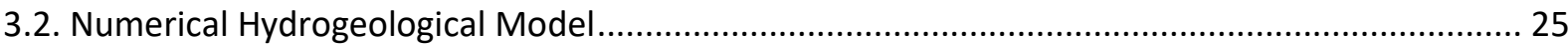

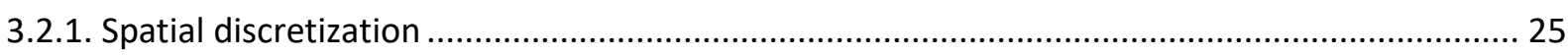

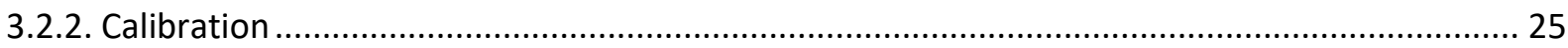

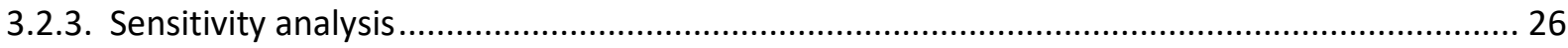

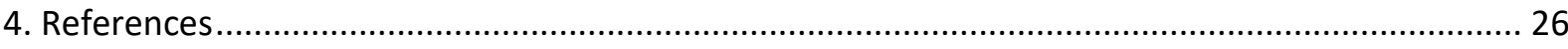

CHAPTER 4 - HYDROGEOLOGICAL MODELING APPLIED FOR MINE PLANNING - CUT-OFF WALLS

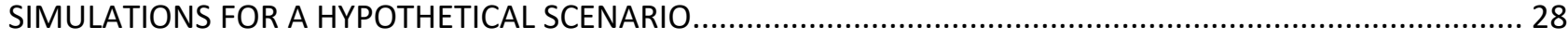

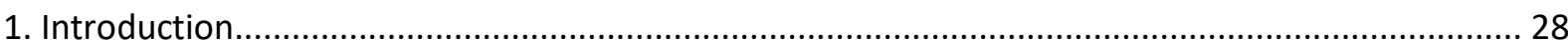

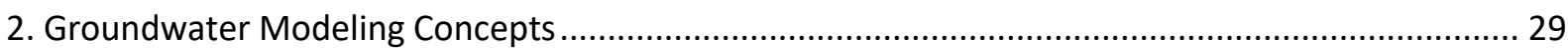

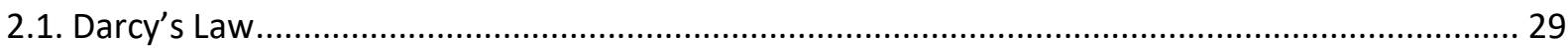

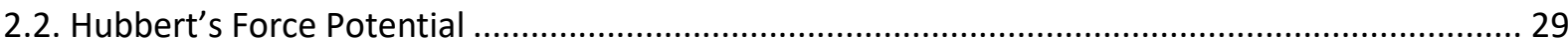

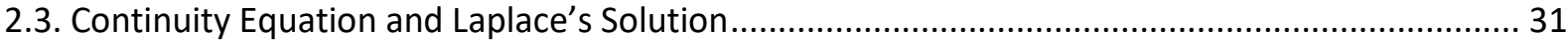

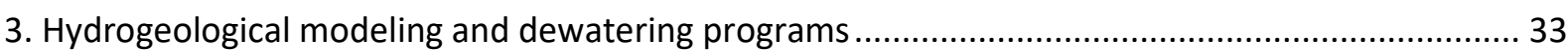

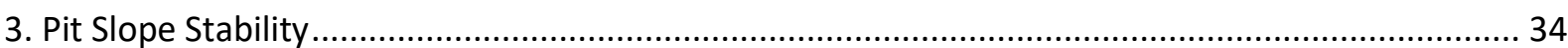




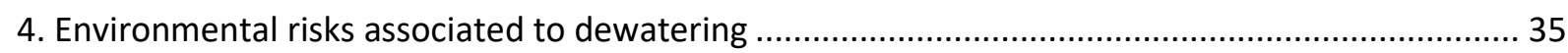

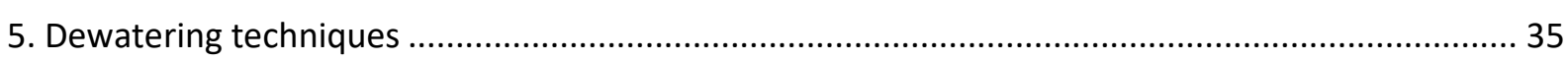

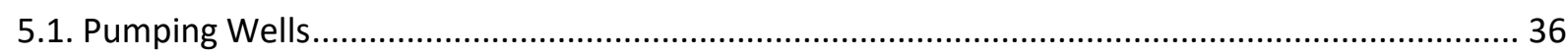

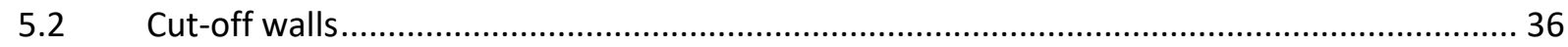

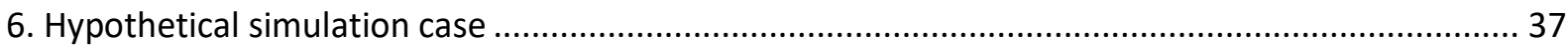

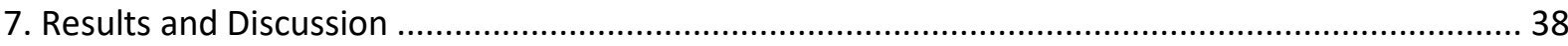

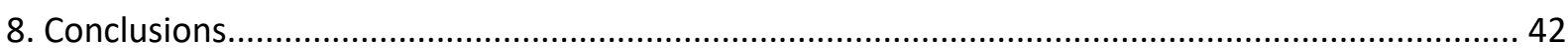

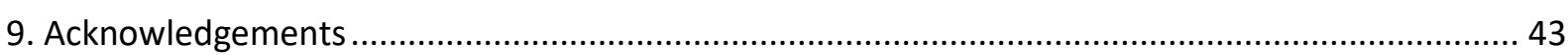

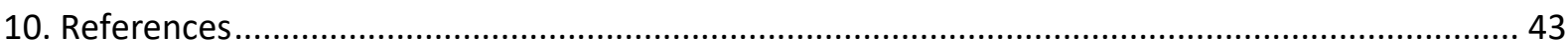

CHAPTER 5 - GEOLOGIC AND TYPOLOGICAL 3D MODEL FOR ALEGRIA MINE, EAST PART OF QUADRILÁTERO FERRÍFERO, MINAS GERAIS, BRAZIL............................................................. 45

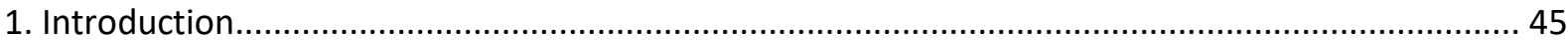

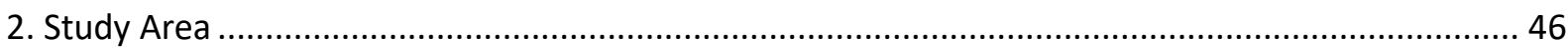

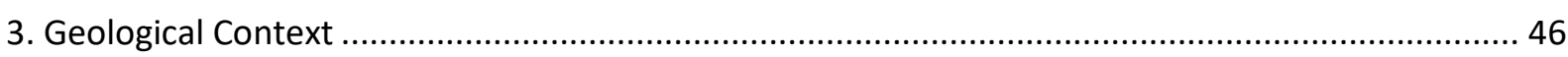

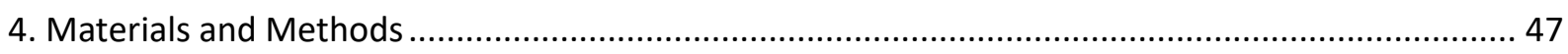

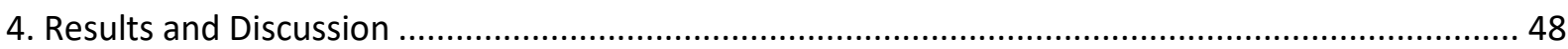

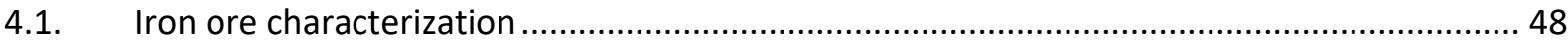

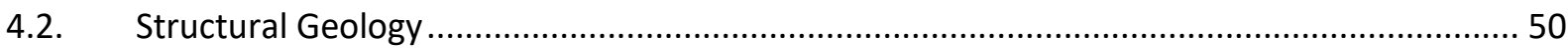

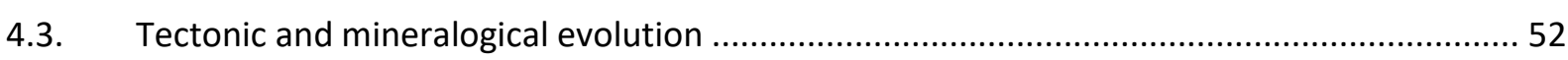

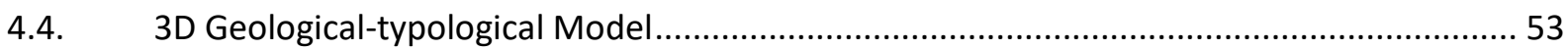

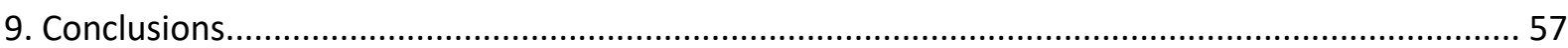

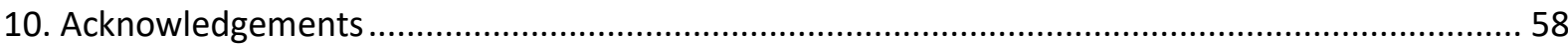

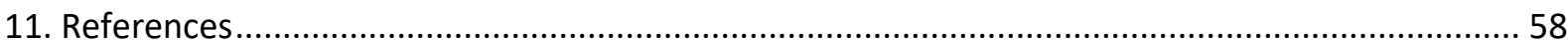

CHAPTER 6 - HYDROGEOLOGICAL CONCEPTUAL MODEL FOR ALEGRIA MINE, EAST PART OF

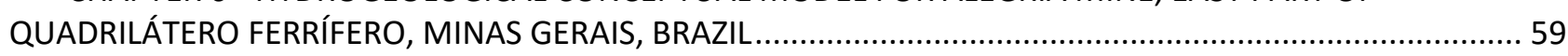

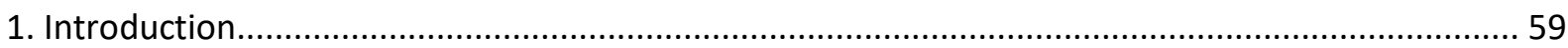

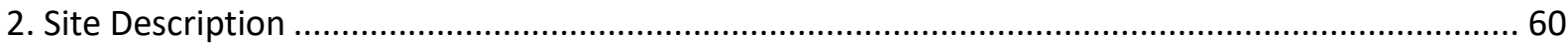

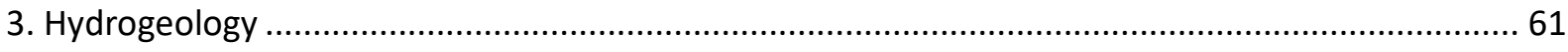

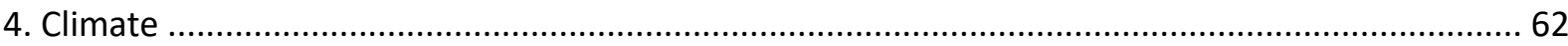

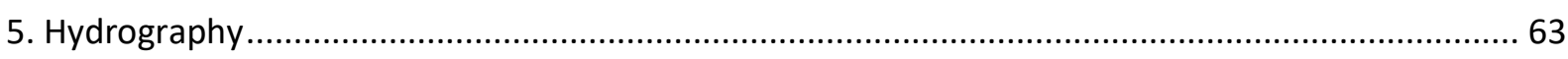

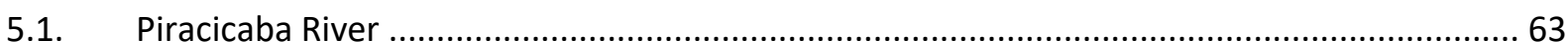

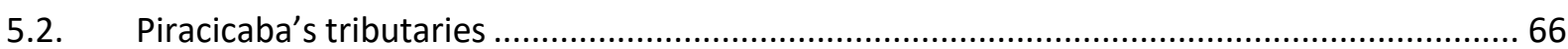

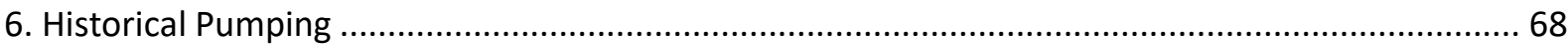

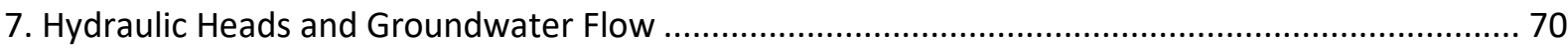

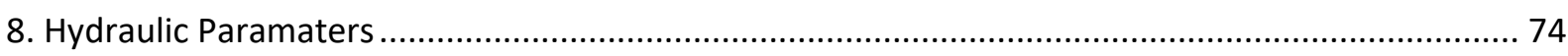

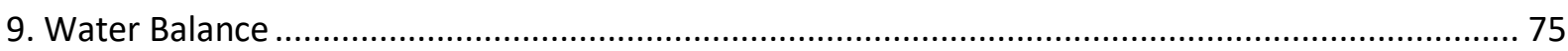

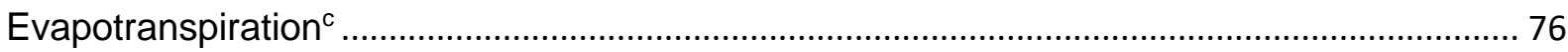

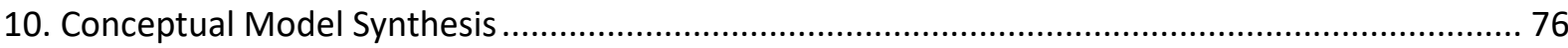

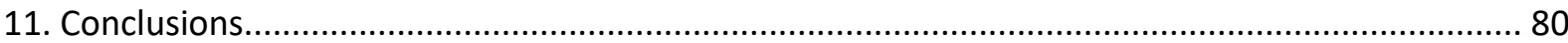

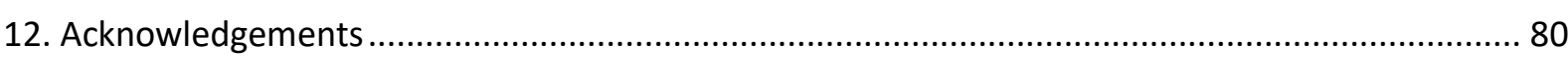


13. References

CHAPTER 7: GROUNDWATER NUMERIC MODEL APPLIED TO DEWATERING IN ALEGRIA MINE, EAST PART

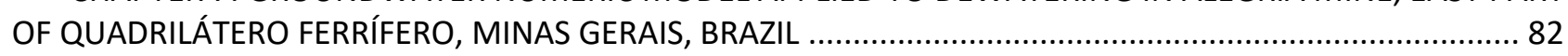

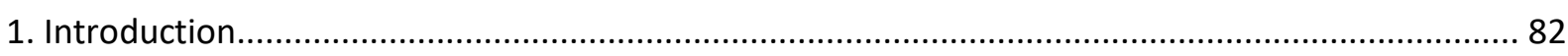

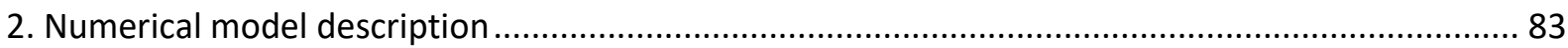

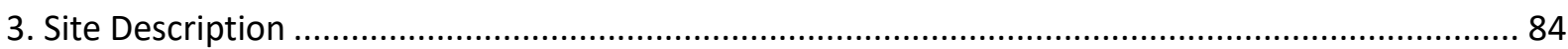

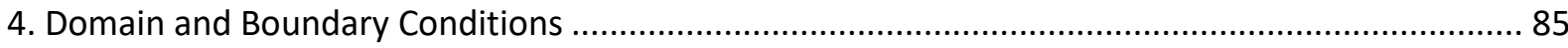

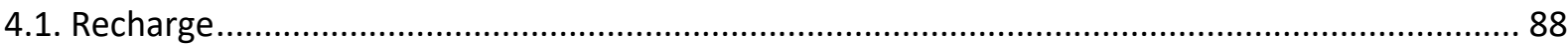

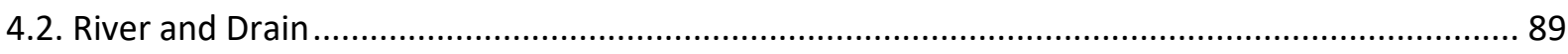

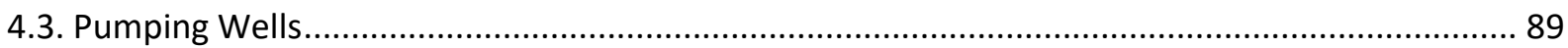

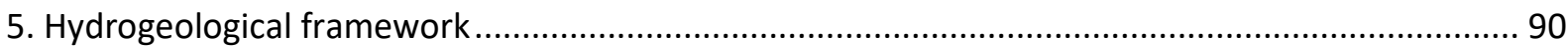

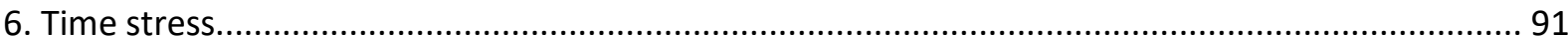

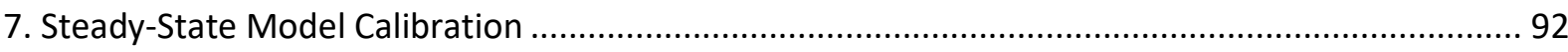

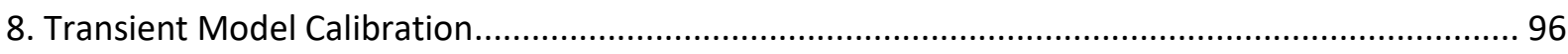

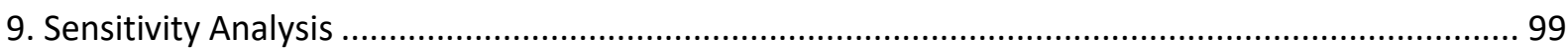

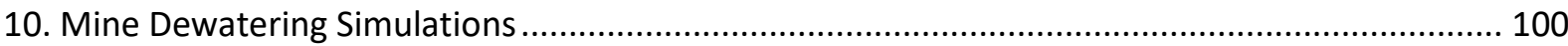

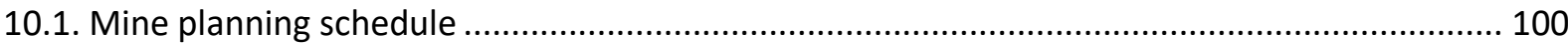

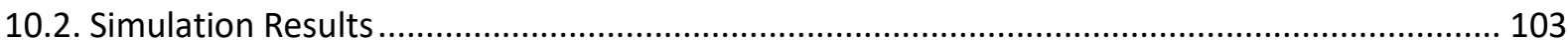

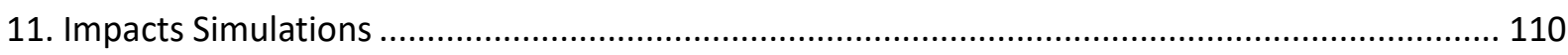

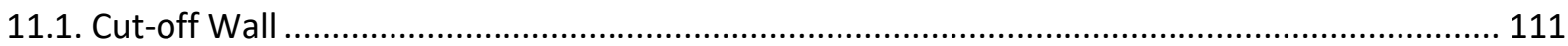

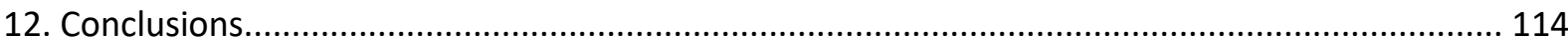

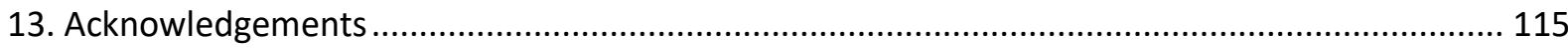

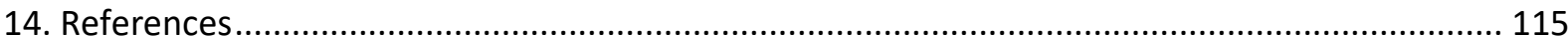

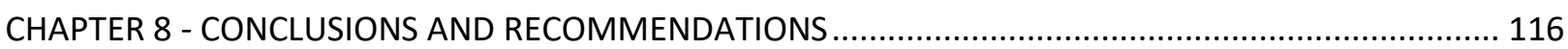

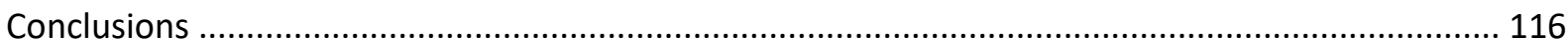

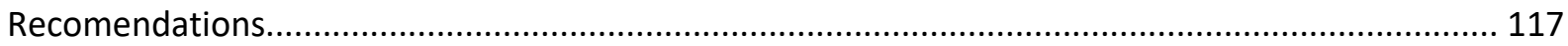




\section{List of Figures}

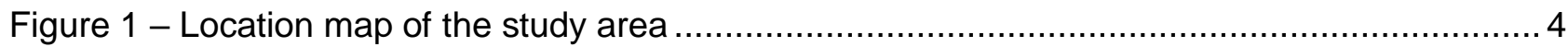

Figure 2 - Temporal distribution of average month rainfall weather stations (2006-2016).............. 6

Figure 3 - Geological sketch map of Quadrilátero Ferrífero (After ALKMIN \& MARSHAK, 1998).... 8

Figure 4 - Cross-sections: A-B from Synclinal Moeda to Synclinal Gandarela and C-D from Homoclinal Serra do Curral to Alegria Synclinal (After DORR, 1969)...................................... 8

Figure 5 - Stratigraphic column of Quadrilátero Ferrífero (after ALKMIN \& MARSHAK, 1998)........9

Figure 6 - Drainage network of Alegria Mina and Piracicaba sub-watershed............................... 12

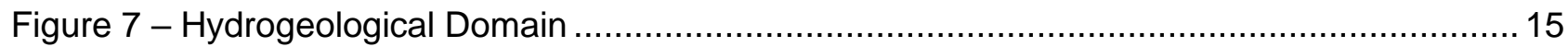

Figure 8 - Surface drainage monitoring map in the central area ............................................ 17

Figure 9 -Spillway in Alegria Mine with (A) Triangular shape; (B) Cipoletti shape; (C) Linnigraph

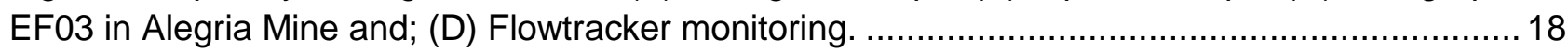

Figure 10 - Location Map of Monitoring Points in Alegria North ............................................ 19

Figure 11 - Location Map of Monitoring Points in (A) Alegria Center and (B) Alegria South.......... 19

Figure 12 - (A) Observation wells in pit, (B) observed well out of pit; Water level measurement

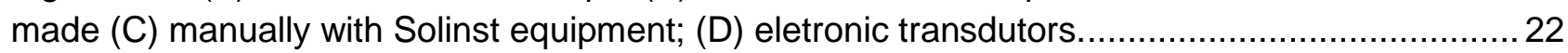

Figure 13 - Pumping wells located in Cauê Aquifer, east part of Quadrilátero Ferrífero.................22

Figure 14 - (A) Weatherhawk automatic station; (B) Ville de Paris pluviometer. ...........................2

Figure 15 - Darcy's experiment with hydraulic head references and pressure on point $P$................30

Figure 16 - Representative Elementar Volume (REV) used to derive the continuity equation.........31

Figure 17 - (A) Victor Mine area before open pit and Attawapiskat River; (B) Victor Mine deposit

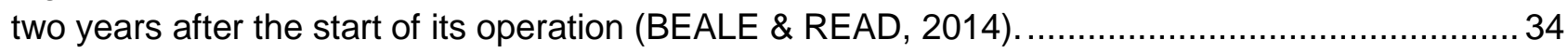

Figure 18- Diavik mine locate in Lac Grass region (DOMINATION DIAMOND, 2014). ...................... 34

Figure 19 - Pumping well profile with the all equipaments ............................................................... 36

Figure 20 - Red fog cut-off wall close to lake (GOLDER, 2016)..................................................... 37

Figure 21 - Horizontal and cross section (row 15) of numerical model with the domain, boundary conditionals, pumping wells and cut-off walls.

Figure 22- Cut-off wall water results simulation. Lower values indicate that cut-off wall prevented water outflow compared to a scenario without the barrier.

Figure 23 - Hypothetical numerical model without cut-off walls with a horizontal view (layer 1) and vertical section (row 15). Cone of depression intercepts the riverbed after 150 days.

Figure $24-$ Hyphotetical numerical model with cut-off walls. Extension reduction of the cone of

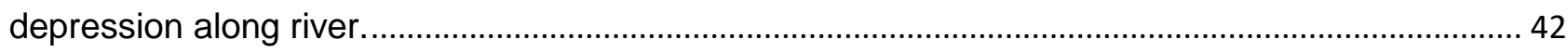

Figure 25 - Map location of study area .................................................................................. 46

Figure 26 - Magnetite (MA), Martite (HM) e Goethite (Gt) - under reflect microscope x300

(Samarco, 2012)

Figure 27-Specular Hematite with lepidoblast and milonitic foliation - under reflect microscope x300.

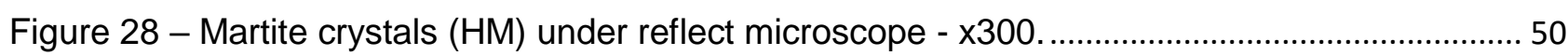

Figure 29 - Porous goethite - under reflect microscope x200 (Rocha, 2008) .............................50

Figure $30-$ A) Stereonet of Alegria North and Center itabirites schistosity; B) Alegria South

schistosity foliation with $\beta$ axis is on the order of 100/40; C) schistosity plane of the entire deposit

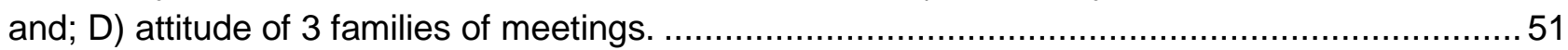

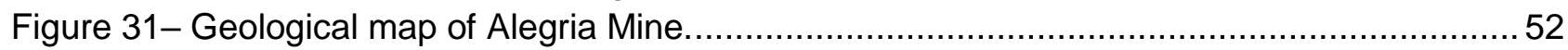

Figure 32- Mineralogical evolution in Alegria Mine ...................................................................... 53

Figure 33- Typical cross section in Alegria South........................................................................... 55

Figure 34- Typical cross section in Alegria Center............................................................................ 55 
Figure 35 - Typical cross section in Alegria North

Figure 36 - Complete geologic-typological modeling in Alegria Mine. .............................................. 57

Figure 37- Location Map of the Alegria Mine and Samarco's mineral tenures ................................6 61

Figure 38- Precipitation and potential evapotranspiration average from 2007 to 2016 .................. 63

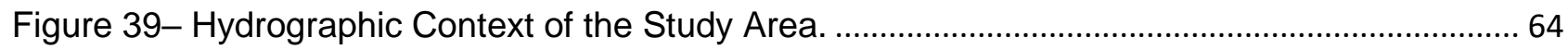

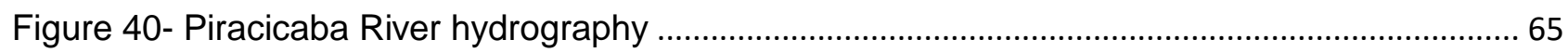

Figure 41- Hystorical average of Piracicaba River flow-rate im EF01, EF02 and EF03 (from 2006 to 2016).

Figure 42- Piracaciba mean flow rate calculated from measurements taken at Fazenda Alegria fluviometric station (from 1971 to 1977) ....................................................................................... 66

Figure 43- Piracicaba River tributaries map with points monitored by spillways and flowtracker ... 66

Figure 44- Macaco creek hydrogram based on data from spillways V2 and V3. ......................... 67

Figure 45- Palmital creek hydrogram based on data from spillways V4 and V5..........................67

Figure 46- Macaco Barbado creek hydrogram based on data from spillways V6 and V7.............. 68

Figure 47- Pumping wells installed in the study area in December 2016 ......................................... 69

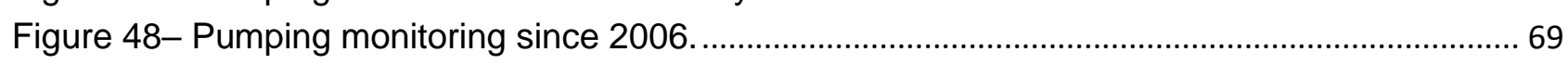

Figure 49 - Location Map of Monitoring Points in Alegria North ......................................................... 70

Figure 50 - Location Map of Monitoring Points in (A) Alegria Center and (B) Alegria South ........... 70

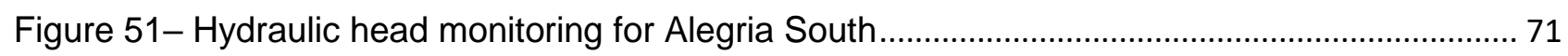

Figure 52 - Hydraulic head monitoring for Alegria Center ................................................................. 71

Figure 53 - Hydraulic head monitoring for Alegria North (E-SE portion)......................................... 72

Figure 54 - Hydraulic head monitoring for Alegria North (W-NW portion). ........................................ 72

Figure 55 - Equipotencial and flow map in May 2006.................................................................... 73

Figure 56 - Hydraulic Parameter: specularite itabirite IE), Martite itabirite (IM), Amphibolitic itabirite

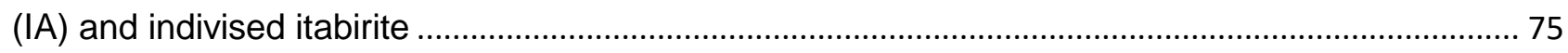

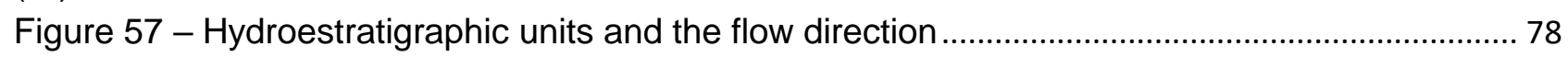

Figure 58 - Sections A-B and C-D showing groundwater flow towards discharge zone in Piracicaba

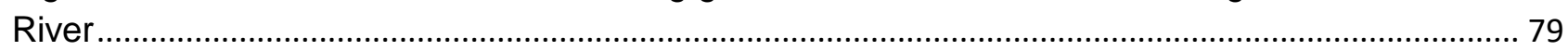

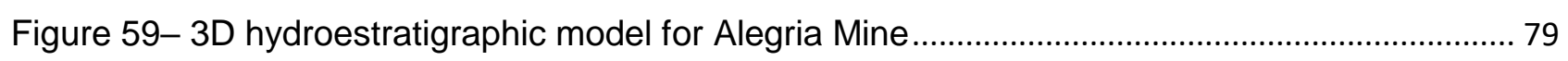

Figure 60 - Geological/hydrogeological units in the Alegria Mine, east part of Quadrilátero

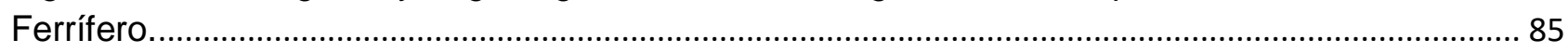

Figure 61 - Model domain and no-flow condition boundaries (inactive cell) in phyllites and

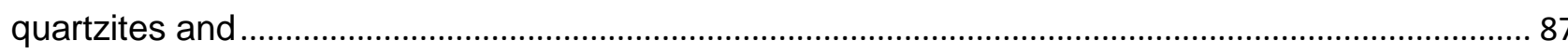

Figure 62- Representative vertical cross section from south to north showed the model domain

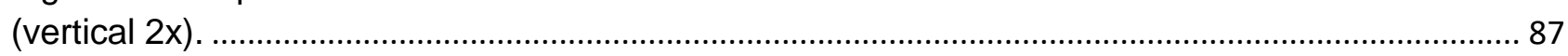

Figure 63 - Recharge zones for steady and transient stages ..................................................... 88

Figure 64 - Recharge values used in the transient model............................................................ 89

Figure 65 - Pumping rate in Alegria Mine over the years. ............................................................... 90

Figure 66 - Pumping well locations in the numeric model. ................................................................ 90

Figure 67 - Alegria Mine hydrogeological framework ..................................................................... 91

Figure 68 - Number of hydraulic heads observations from June 2006 to June 2016 used in

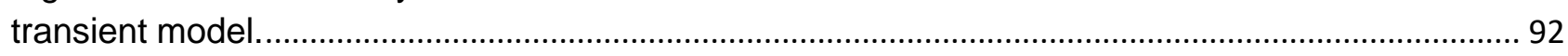

Figure 69 - Plot of hydraulic heads observed versus calculated for steady-state model. ................. 93

Figure 70 - Water mass balance discrepancy obtained for steady-state model. ............................. 94

Figure 71 - Potentiometric and groundwater map for steady-state model....................................... 94

Figure 72 - Vertical sections of potentiometric map for steady-state model.................................... 95 
Figure 73 - Calculated and observed flow rates comparison for Piracicaba River and creeks for steady-state model.

Figure 74 - Normalized RMS error versus time for transient model. ................................................. 98

Figure 75 - Residual Mean, Absolute Residual Mean, RMS Error and Standard Error. .................. 98

Figure 76- Water mass balance discrepancy (\%) for transient model............................................. 99

Figure 77- Sensitivity analysis of the calibrated model considering the recharge and hydraulic conductivity

Figure 78- Mine planning schedule for Alegria North an Alegria Center......................................... 101

Figure 79- Mine planning schedule for Alegria South ....................................................... 102

Figure 80 - Mine pit bottom elevation and drawdown level reached by pumping wells in Alegria

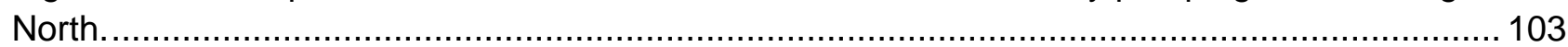

Figure 81 - Dewatering simulation for Alegria North. ........................................................ 104

Figure 82 - Mine pit bottom elevation and drawdown level reached by pumping wells in Alegria

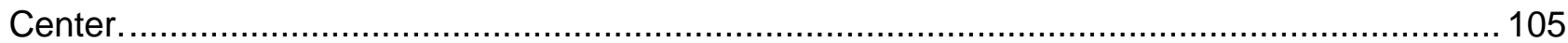

Figure 83 - Dewatering simulation for Alegria Center ...................................................................... 105

Figure 84 - Dewatering simulation for Alegria South.......................................................................... 106

Figure 85 - Mine pit bottom elevation and drawdown level reached by pumping wells in Alegria

South.

Figure 86 - Pumping rates over time in Alegria Mine......................................................................... 107

Figure 87 - Location map for pumping wells installed from 2017 to 2027 .................................... 108

Figure 88 - Location map for pumping wells installed from 2028 to 2042 ..................................... 109

Figure 89 - Sub-catchments considered for base-flow monitoring................................................... 110

Figure 90 - Rivers and creeks baseflow reduction over time due to mine dewatering. .................. 111

Figure 91 - Cut-off walls location along Piracicaba river (layer 20) . ................................................ 112

Figure 92- Drawdown simulation using cut-off walls on both sides of Piracicaba river (column 98)

Figure 93- Baseflow reduction (\%) between fluviometric stations............................................. 114 


\section{List of Tables}

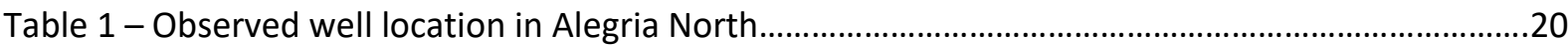

Table 2 - Observed well location in Alegria Center...................................................................................20

Table 3 - Observed well location in Alegria South......................................................................................21

Table 4 - Pumping well location in Alegria Mine.......................................................................................23

Table 5 - General simulation input data of cut-off walls models..............................................................38

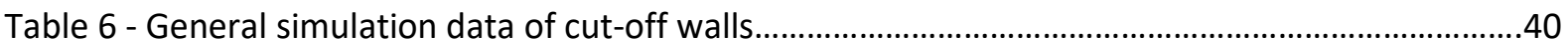

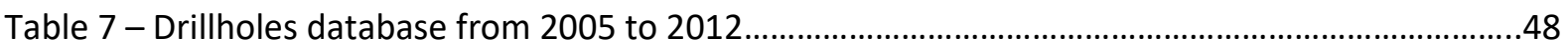

Table 8 - Hydraulic parameters obtained with pumpins tests..................................................................73

Table 9 - Hydraulic parameters obtained with slug and recovery tests.................................................74

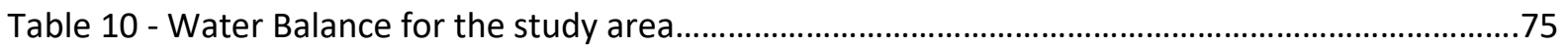

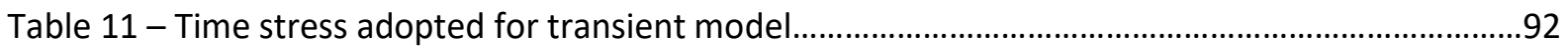

Table 12 - Initial, range and calibrated parameters values for steady-state and transient models......96

Table 13 - Stress period versus pit bottom. 102 


\section{CHAPTER 1 - INTRODUCTION}

The establishment of globalized markets has created an extremely competitive environment for mining companies, forcing them to improve their industrial process, within a concept of economic, environmental and social sustainability. Technical and economic feasibility of a mine is very conditioned to the adequate knowledge of the hydrogeological context in which it is inserted and to the subsequent mining operations to access ore reserve below the water level. This leads to dewatering mine areas, which culminates in extensive cones of depression.

Inserted in this technical-economic context, Quadrilatero Ferrífero Discrict (QF) located in the southeast part of Brazil is one of the leader's places in the production and export of iron ore around the world. In order to maximize the ore reserve, mining companies are investing in advanced mineral research, with the objective of quantifying the iron ore from Caue Formation, predominantly composed of metamorphic banded iron formations, known as itabirites. These paleo-proterozoic rocks were submitted to diagenetic and tectonic-metamorphic processes that led to the formation of fissural porosity, due to the occurrence of faults and fractures. Efficient chemical and physical weathering increased this secondary porosity, making this geological unit the main aquifer of the region (MOURÃO, 2007).

Since 1991 Samarco Mineração S.A. has explored and processed itabirites from Caue Formation in Alegria Mine in the east part of QF, which nominal production capacity was almost 30 million tons of iron ore pellets per year in 2014. Hydrogeological studies should be necessary and sufficient to subsidize the mining planning in Alegria Mine to access the ore reserve bellow the water surface. In the interest of justify cost-benefit-based progress in dewatering mine operation, numerical modeling of groundwater flow was applied to predict drawdown behavior.

This dissertation describes the methodology and tools used in the conception, development, calibration and interpretation of the computational model of groundwater flow for Alegria Mine and surrounding areas. All data based on a large set of information, such as borehole data, historical monitoring of flow rate in the Piracicaba River and surrounding streams, observation and pumping wells, aquifer tests and meteorological data.

\subsection{Objectives and justifications}

The main objective of this research was the construction of a numerical model of groundwater flow for the mines of Alegria North, Center and South to support the simulation of scenarios that would achieve successfully the mine dewatering for its exploitation for more 25 years. Results obtained with this study could be considered in Samarco management plan and further application of financial investments, besides helping to understand the mine operational challenges in new conditions.

The specific objectives are related to: 
- Establish the geological configuration of the study area using the data obtained in existing survey reports;

- Evaluate monitoring data from meteorological stations, observation wells, pumping wells, fluviometric stations, spillways and manual measurements acquired with flow tracker equipment in Piracicaba River and others tributaries;

- Integrate all data into a hydrogeological conceptual model;

- Develop and calibrate a numerical model that represents groundwater flow observed in the Alegria Mine area and surroundings;

- Evaluate the alternatives to mine dewatering using the calibrated transient model.

\subsection{Structure of dissertation}

This dissertation is presented in the form of scientific manuscripts in order to facilitate the submission of the results to national and international journals with renowned editorial board. The text is articulated in seven chapters, four of them manuscripts self-sustainable (Chapters 4 to 7 ).

Chapter 1 addresses to an introduction to the research subject and related objectives.

Chapter 2 presents a brief description of the study area, with location and climatic and geomorphological aspects, regional geology, hydrogeology and aquifers descriptions. In this chapter presents a brief sintesys of previous research in Alegria Mine.

Chapter 3 details the materials and methods employed to develop conceptual and numerical models for the study area.

Chapter 4 compiles the bibliography survey mainly concerned to dewatering techniques applied in mines around the world. This chapter illustrates the application of hydrogeological modeling in mine planning, since the opening of the pit until its closure. Examples of mines in operation that used numerical hydrogeological modeling are presented and support a hypothetical numeric model which simulates a cut-off wall close to Piracicaba River to preserve its flow rate.

Chapter 5 presents the geological and typological 3D model for the study area. For specific lithotypes that constitute the main geological unit, discussion regarding the metalogenetic process is also provided. Classification of itabirites as their mineralogical characterization is detailed in this chapter.

Chapter 6 provides the hydrogeological conceptual model of Alegria Mine, with presentation of the main hydrogeological units, model domain and contour conditions and water balance given by interaction among recharge (rain), rivers and aquifer and also the extraction by pumping wells This conceptual model synthesized all available geological, hydrological and weather data, and will describe the hydrogeological system and the processes within it.

Chapter 7 presents the numerical hydrogeological model and results of the dewatering simulations using pumping wells and second step the cut-off walls. 
And lastly Chapter 8 presents the conclusions of the research and recommendations for further studies. Monitoring data from Alegria Mine, location of instruments, information on the pumping wells, can be found in electronic data that follows this dissertation. 


\subsection{Location}

Alegria Mine is located in the center-south portion of Minas Gerais State, between the municipalities of Ouro Preto and Mariana. The area of study is located in upper watershed of Piracicaba River. In Figure 1, it is possible to observe the Piracicaba River sub-basin surrounded by mountains from a national park "Serra do Caraça", which drains locally approximately $76 \mathrm{~km}^{2}$. According to geography reference and pit operation, Alegria Mine can be sub-divided in three sectors: Alegria North, Alegria Center and Alegria South.

The main route to Alegria Mine is through BR-356 Road, which connects the capital of Minas Gerais State, Belo Horizonte, to Mariana city, distant from each other for about $110 \mathrm{~km}$. Leaving from Mariana, 11km on MG-129 Road drives to Antônio Pereira district, from where for more $20 \mathrm{~km}$ the industrial unit of Alegria Mine can be accessed.

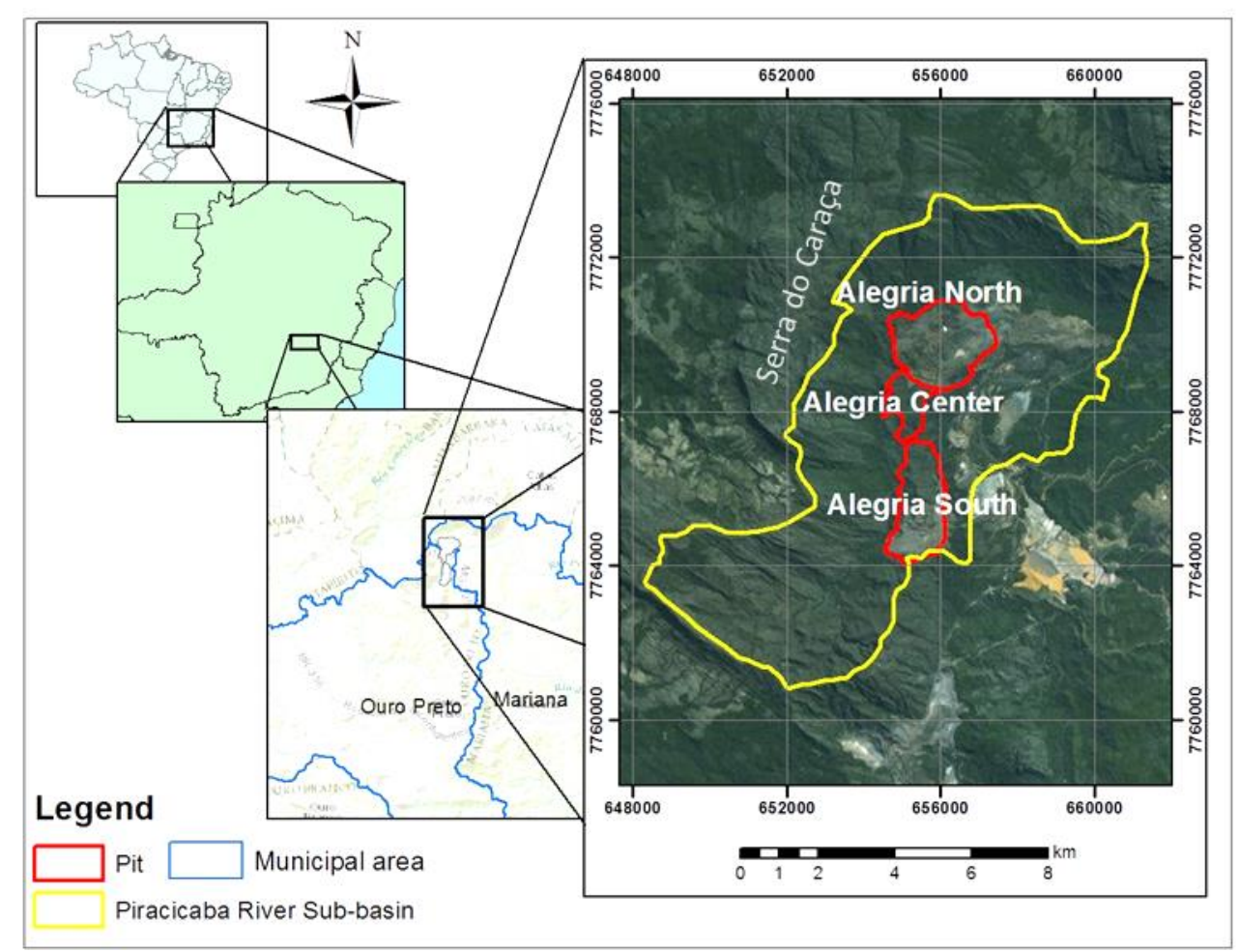

Figure 1 - Location map of the study area

\subsection{Previous Research}

A synthesis of some geological and hydrogeological studies carried out in the Cauê Aquifer that can be used as a source of this work is presented. 


\section{Structure and iron ore formation: Alegria Mine Deposit, Quadrilátero Ferrífero,}

Minas Gerais (Veríssimo, 1999)

The geological mapping carried out by Veríssimo (1999) in the western portion of the Alegria Mine made it possible to determine the different tectonic structures, followed by kinematic and dynamics structural analysis. The iron ores in Alegria Mine exhibit a lenticular and imbricated geologic contact related to the thrust-faults and shear-zones. The mineralization geometry was conditioned by metamorphic tectonic processes and later by supergenesis, generating a mineralogical diversity itabirites.

\section{Hydrogeological characterization of the Caufer Aquifer (Mourão, 2007)}

In this study, Mourão (2007) developed her thesis to evaluate Cauê Aquifer dynamic groundwater circulation in the western part of Quadrilátero Ferrífero. The hydrogeological characterizations were based in fieldwork, permeability and porosity laboratories test and core trays description. In addition to the field activities, this work developed the hydrochemical and isotopic characterization. As the region contains several iron ore mines, this work also aimed to understand the dynamics of groundwater flow in this region and the impacts caused by depletion.

Typology and mineralogical definition and microstructural characterization of amphibolitic itabirite in Samarco's Minas de Alegria Mineração S.A. - Minas Gerais (Rocha, 2008)

In this study, it was performed a detailed mineralogical characterization of the Alegria Mine amphibolitic itabirites, using a lack of techiniques: size and chemical analysis, $x$-Ray diffratometry, infrared spectrometry, thermogravimetry, optical and scanning electron microscopy. Metallurgical process grinding, desliming and flotation were used to determine the amphibolitic itabirites ore behavior during beneficiation plant. The mineralogical association of amphiboles, iron oxides, quartz and carbonates reinforce their origin to be the iron ore formations of the silicate or oxidesilicate facies associated with carbonates layers.

\section{Mechanical and hydrogeological characterization in Alegria Center and South.} (Carneiro, 2013)

In this dissertation, the rock mass hydraulic characterization in a specific area between Alegria South and Alegria Center was developed. The main objective of this study was to evaluate the safety factor of the future slopes near the Piracicaba River that can be influenced by groundwater pore-pressure. Some infiltration and paker test tests were carried out to examine diferents types of itabirites hydraulic conductivities. Drawdown groundwater becomes mandatory to maintain slopes within stability assumptions. 


\subsection{Climate and Physiography Aspects}

Alegria Mine is located in the region of "Serra do Caraça" in its southern portion. Extremely mountainous relief characterizes the region, where altimetric amplitude ranges from $2,072 \mathrm{~m}$ on "Serra do Caraça" peak to $900 \mathrm{~m}$ in the Piracicaba River valley.

Piracicaba River, main river in the region, starts its watercourse at the southwest part of the upper Piracicaba River sub-basin. The main Piracicaba River tributaries, which are situated on its left bank, have their springs at high lands formed by eroded quartzites in "Serra do Caraça" mountains. They enter the area of Alegria Mine close to the mountain domain constituted by metamorphic banded iron formation, which sustains a still quite hilly relief with lower levels (up to $1,350 \mathrm{~m})$, and drain towards Piracicaba river, at $900 \mathrm{~m}$ elevation. Geomorphology also shows a very sharp carving of the drainage network, which intersects regional geological structures.

According to Köppen climatic classification, the region presents a tropical altitude climate (mesothermic), with wet summers and dry winters. Evaluate the data come from six metherological station along the study area there are two distinct period with a rainy season from October to March and a dry season from April to September. In the Figure 2, the modal distribuction in two distict periods is an average of 10 years monitoring in 6 weather station. The annual average precipitation is $2,189 \mathrm{~mm}$.

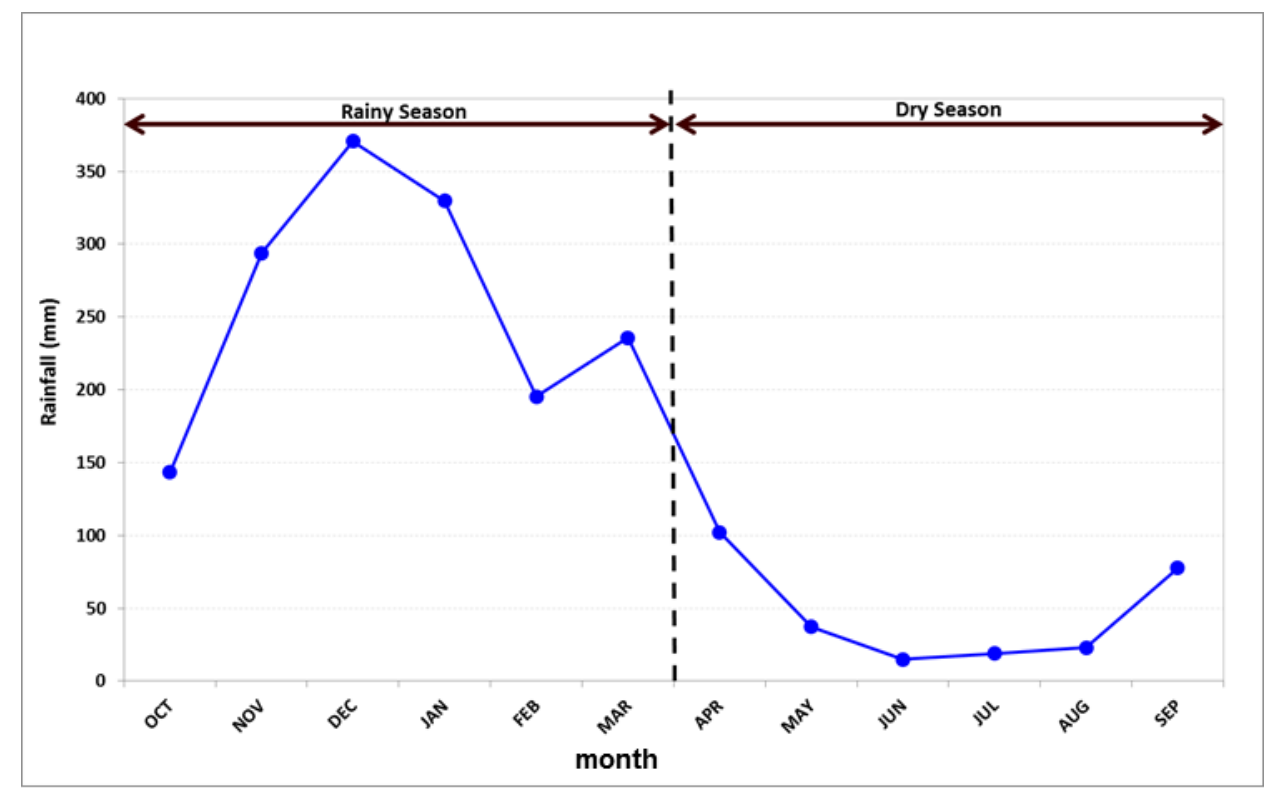

Figure 2 - Temporal distribution of average month rainfall weather stations (2006-2016).

\subsection{Regional Geology}

The Quadrilátero Ferrífero District (QF) is located in the southern São Francisco Craton (ALMEIDA, 1977), which is limited by Brasiliano fold-thrust belts (Figures 3 and 4). At least four great pre-Cambrian orogenetic cycles are found in the QF and surroundings (ROMANO, 1989; CARNEIRO et al., 1992; NOCE, 1995; and ALKIMIN \& MARSHAK, 1998). The great first 
orogenetic cycle was Jequié, which took place from 2.8 to 2.6 Gy (billion years ago). The second, the Transamazonian orogeny, occurred from 2.1 to $1.8 \mathrm{~Gy}$. The third was Espinhaço Rift Event that occurred almost in the end of Paleoproteroic. Moreover, the last great orogenetic cycle in QF was the Brazilian fold-thrust belt. All those tectonic-metamorphics events are associated with the structuring of three large groups of rocks (Figure 5): metamorphic complexes, greenstone belts and supracrustal metasedimentary sequence (ALKMIN \& MARSHALL, 1998).

Metamorphic complexes are Archean basement crystalline rocks (2.9-3.2 Gy) that subdivided in two lithological groups. High grades metamorphic rocks constituted usually by gneiss/milonite characterize the embasement. Igneous rocks with low metamorphic rates, besides metassedimentary and metassomatic rocks, compose the second lithological group.

Associated with tectonics in fold-thrust belts, the greenstone belt sequence is composed by Rio das Velhas Supergroup rocks. Characteristically, the Rio das Velhas Supergroup is constituted by metakomatiits, metabasalts, chlorite-tremolite schists and Algoma banded iron formation.

A supracrustal Minas Supergroup metasedimentary sequence unconformably overlies the Rio das Velhas Supergroup and its regional stratigraphic column divided into Caraça, Itabira and Piracicaba groups. The basal units of metasedimentary sequence are composed by Moeda and Batatal formations. Moeda Formation is constituted of fine coarse quartzite with lenses of sandy phyllites, metaconglomerates and sericitic quartzite. Batatal Formation, which occurs in transitional contact with the Moeda Formation, is composed by sericitic and carbonaceous phyllites and ferruginous quartzite.

In a transitional contact, a chemical metasediments sequence is recognized by Itabira Group, which is subdived in Cauê Formation and Gandarela Formation. The Cauê Formation is composed mainly by metamorphic banded iron formation and it is the most economically import unit in QF, from where it is extracted millions of tons of iron ore per year. Metamorphic banded iron formation, also known as itabirite, can be divided into quartz-itabirite, amphibolitc itabirite and dolomitic itabirite (VERÍSSIMO, 1999). Cabonates rocks from Gandarela Formation overlie gradually the Cauê Formation itabirites.

Unconformably, the Piracicaba Group overlies the Itabira Group by erosive discordance. The Piracicaba Group was composed mainly by plyllites and quatzites. Two supracrustal sequences composed the top of QF stratigraphic column: Sabará and Itacolomi groups. Sabará Group is a sequence of meta-volcaniclastics, meta-tuffs, meta-turbidites and meta-diamictites (RENGER et al, 1998). In an angular discordance, Itacolomi Group is discordant of Minas Supergroup and it is represented by fluvial meta-sandstones, metaconglomerates, alluvial sediments and fluvial meta-argillites. The great tectonic mobility provided the intrusion of metabasites that cut all geological units of QF. 


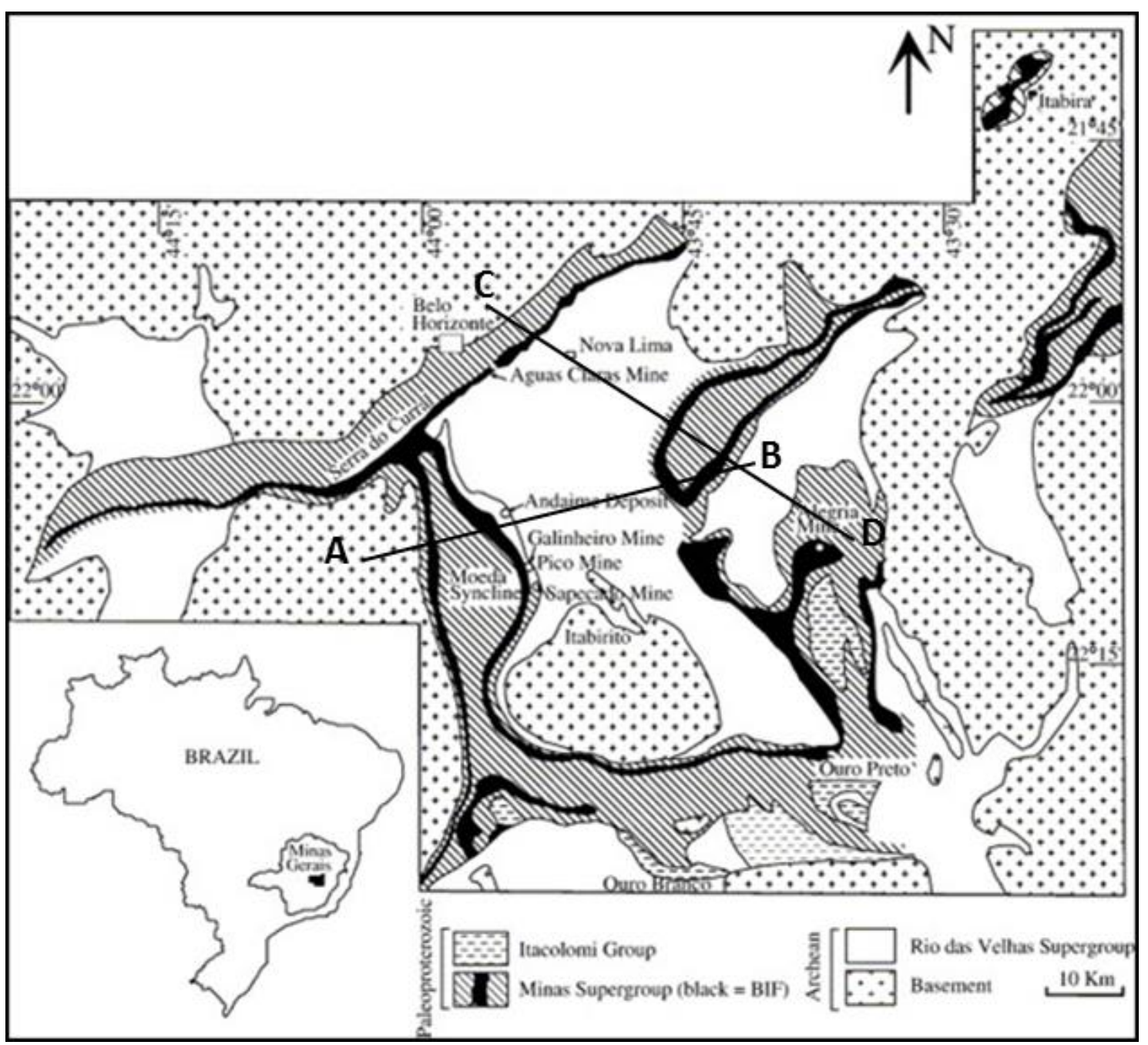

Figure 3 - Geological sketch map of Quadrilátero Ferrífero (After ALKMIN \& MARSHAK, 1998)
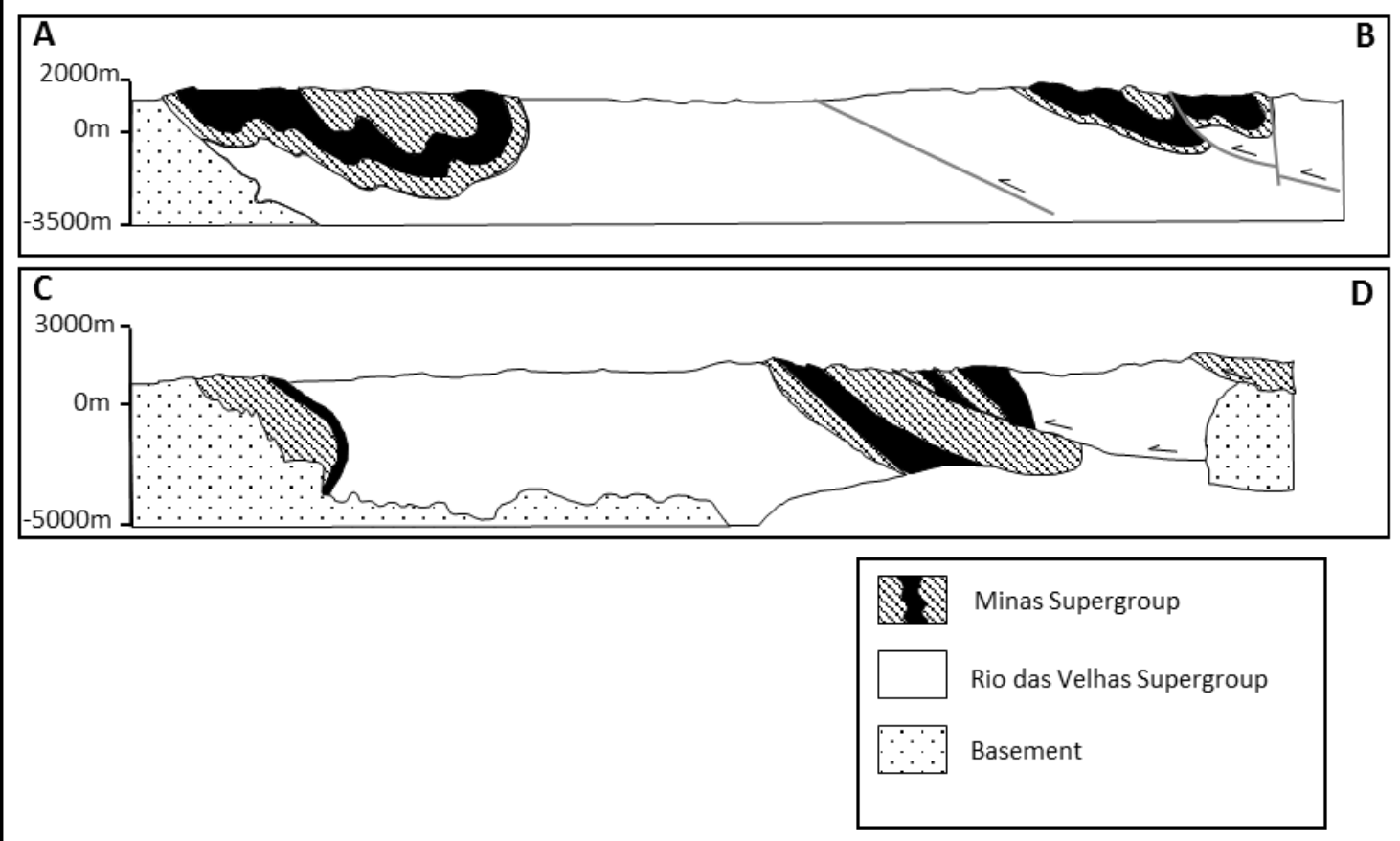

Figure 4 - Cross-sections: A-B from Synclinal Moeda to Synclinal Gandarela and C-D from Homoclinal Serra do Curral to Alegria Synclinal (After DORR, 1969). 


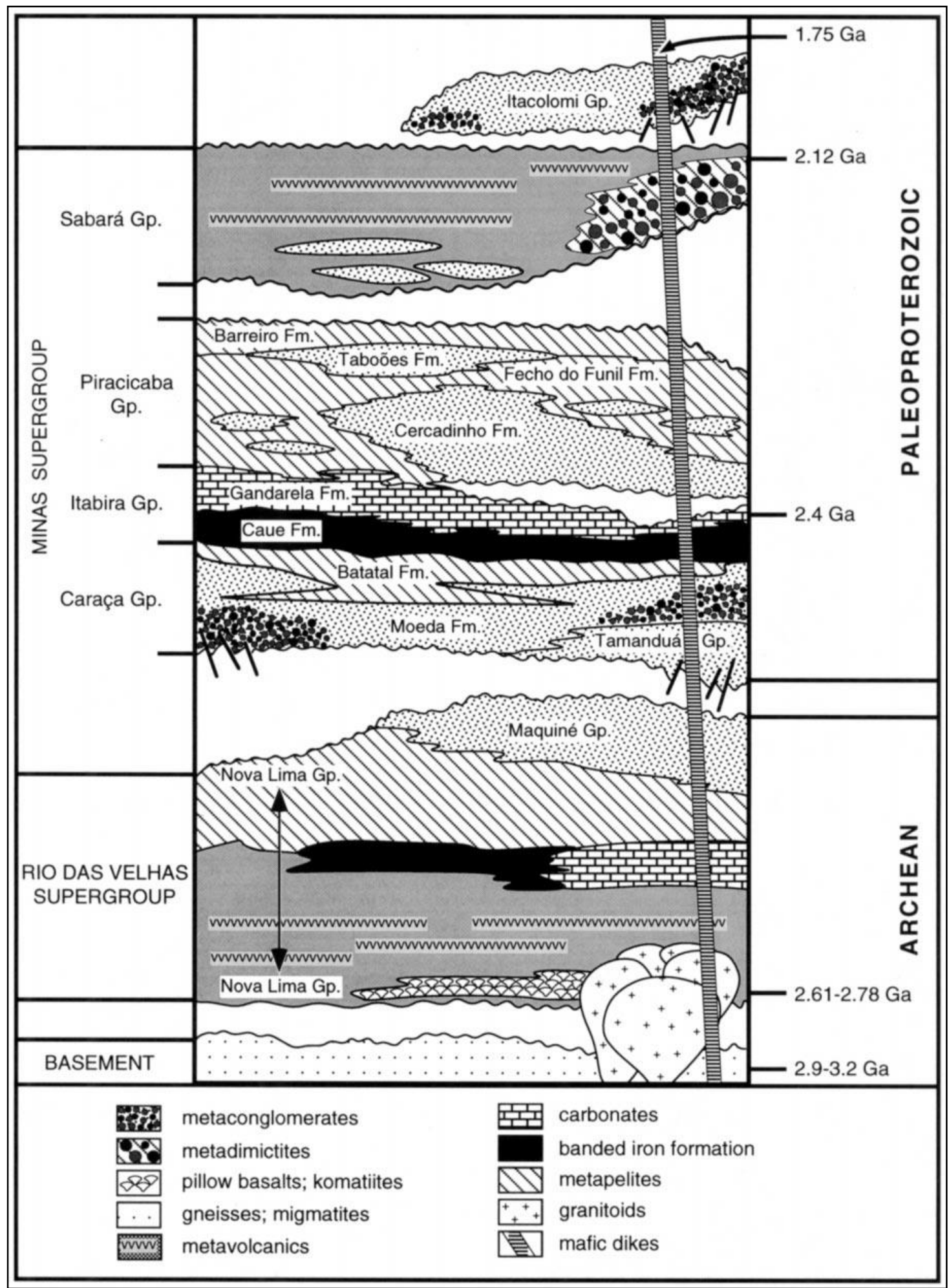

Figure 5 - Stratigraphic column of Quadrilátero Ferrífero (after ALKMIN \& MARSHAK, 1998)

\subsection{Hydrogeology and aquifers descriptions}

The hydrogeological units that compose the Alegria Complex follow the same stratigraphic sequence as the eastern part of Quadrilátero Ferrífero, being composed by quartzites, phyllites and itabirites of Supergroup Minas. On the base of stratigraphic collumn, quartzites from Moeda 
Formation occupy the highest positions of Serra do Caraça mountain in which the circulation of water is mainly done through discontinuities. The altered zone behaves like a granular aquifer. This aquifer system is independent of the Cauê Aquifer system by Aquiclude Batatal. The Batatal Formation, also known by Batatal Aquiclude, consists by phyllites at lower elevation, and it is advertised as the most remarkable regional hydraulic barrier.

Occupying the central part of the study area, stratigraphically positioned between the Batatal Aquiclude and the rocks of the Piracicaba Group, the Cauê constitute the main aquifer at the regional level, with hydraulic conductivity values obtained through pumping, recovery and slug-test tests. The contrast of hydraulic conductivities values between Cauê aquifer and the other hydrogeological units favored concentration of groundwater circulation, being one of the main factors of metallogenic processes and ore mineralization.

Cauê Aquifer consists of itabirites and ferruginous quartzites from Cauê Formation, the most import geological unit to iron ore extraction in Quadrilátero Ferrífero. It is a regionally unconfined aquifer, in some areas confined, with high values of interstitial porosity and fissural porosity, due fracturing and fault zones (SILVA et al., 1994). The intense weathering and fractures makes Cauê aquifer behave as dual porosity aquifer. The high heterogeneity and anisotropy reflected in the wide range of hydraulic conductivity values from $5.4 \times 10^{-5} \mathrm{~m} / \mathrm{s}$ to $3.0 \times 10^{-8} \mathrm{~m} / \mathrm{s}$. The typical structure of itabirite makes the Cauê aquifer quite anisotropic (MOURÃO, 2007).

The Cauê Aquifer groundwater is characteristically low mineralized with an average electrical conductivity of $10.2 \mu \mathrm{S} / \mathrm{cm}$ and an average $\mathrm{pH}$ of 5.96. In Pipper diagrams, it is possible to observe a tipical hydrochemical signature of the Cauê Aquifer, very close to the hydrochemical composition of the meteoric waters (MOURÃO, 2007). Transmissivity values from pumping tests and other tests show values from $50 \mathrm{~m}^{2} /$ day to $2,500 \mathrm{~m}^{2} /$ day. The storage coefficient for Cauê Aquifer in unconfined areas is approximately 0.15 . In the other hands, the storage coefficient in isolated confined areas is around $1.0 \times 10^{-4}$ (SILVA et al, 1994). The thickness of the Cauê Aquifer varies according to its structural geometry, itabirite and mineralization shapes, fracturing intensity and weathering degree.

Overlap Caue Aquifer, quartzites and phyllites sequence from Piracicaba Group occurs in a tectonic contact and it is the top of geological unit in Alegria Mine. The hydrodynamic data are insufficient to indicate exactally its specific capacity, but according to Silva et al. (1994), pumping wells can be values range from 15 to $150 \mathrm{~m}^{3} / \mathrm{h} / \mathrm{m}$.

The discontinuous metabasite dikes cut all the previous sequence, compartmentalized some hydrogeological units, which behave locally as hydraulic barriers. Finally, coluvion and detrital flows that overlies itabirites from Cauê Aquifer is an important way to effective recharge and storing sater durting dry seasons.

Some hydrogeological studies developed mainly by mining companies increased the Cauê Aquifer knowledge and its dynamics behavior during intense drawdown. These studies are 
necessary to figure out wich type of drawdown structures is most suitable, dimensional pumping wells necessary, to make a budget of pumping and to evaluate environment impacts during the mine planning evaluation step, even before the opening of mining.

\subsection{Surface Drainage Network}

The Piracicaba river streamflow starts at Caraça Mountains and crosses Alegria Mine in an approximate SW-NE direction, separating two mines: Alegria South and Alegria Center. In the study area, Piracicaba river watershed has a steep topography and high elevation gradient varied from $1650 \mathrm{~m}$ to $900 \mathrm{~m}$, point where is the outflow location.

The main streamflows of Piracicaba River inside the study area are the Palmital, João Manoel, Macacos and Macaco Barbado streams, all of which are instrumented with spillways (Figure 6). All monitoring data will be described in the next chapters. The succinct description of the watercourses in the study area follows:

Palmital stream: It is located in the eastern portion of the Alegria Mine and its top spring and streamflow locate in the Moeda Formation. This stream is the first tributary to flow to Piracicaba river in Alegria Mine.

Macacos stream: This stream is located in the southeast portion of Alegria Mine and it has a preferred N-S direction. Its head is in the domain of the Piracicaba Formation in contact of Cauê Formation. As there are mining activities close to this stream, it is quite anthropized by damms.

Macaco Barbado Stream: Located in Alegria Center, the top springs and streaflow is in the domain Cauê Formation. In this region, this watercourse is strongly influenced by a fault, which determines a fairly straight drainage pattern with N-S directions.

João Manoel stream: this stream is between Alegria North and Alegria Center, place of disposition of barren. Given the operational needs of mining and environmental legislation, this stream was transposed in a block channel.

Jatobá stream: located in Alegria Norte Mine, this stream is being strongly influenced by groundwater depletion. The springs are found in the Cauê Aquifer, where important discharges zone.

Almas Stream: It is a Piracicaba river tributary in the norther region, a place owned by Vale (a portion north of Alegria Mine). The watercourse of this stream is under contact between the quartzite of Moeda Formation and the phillites of Batatal Formation. 


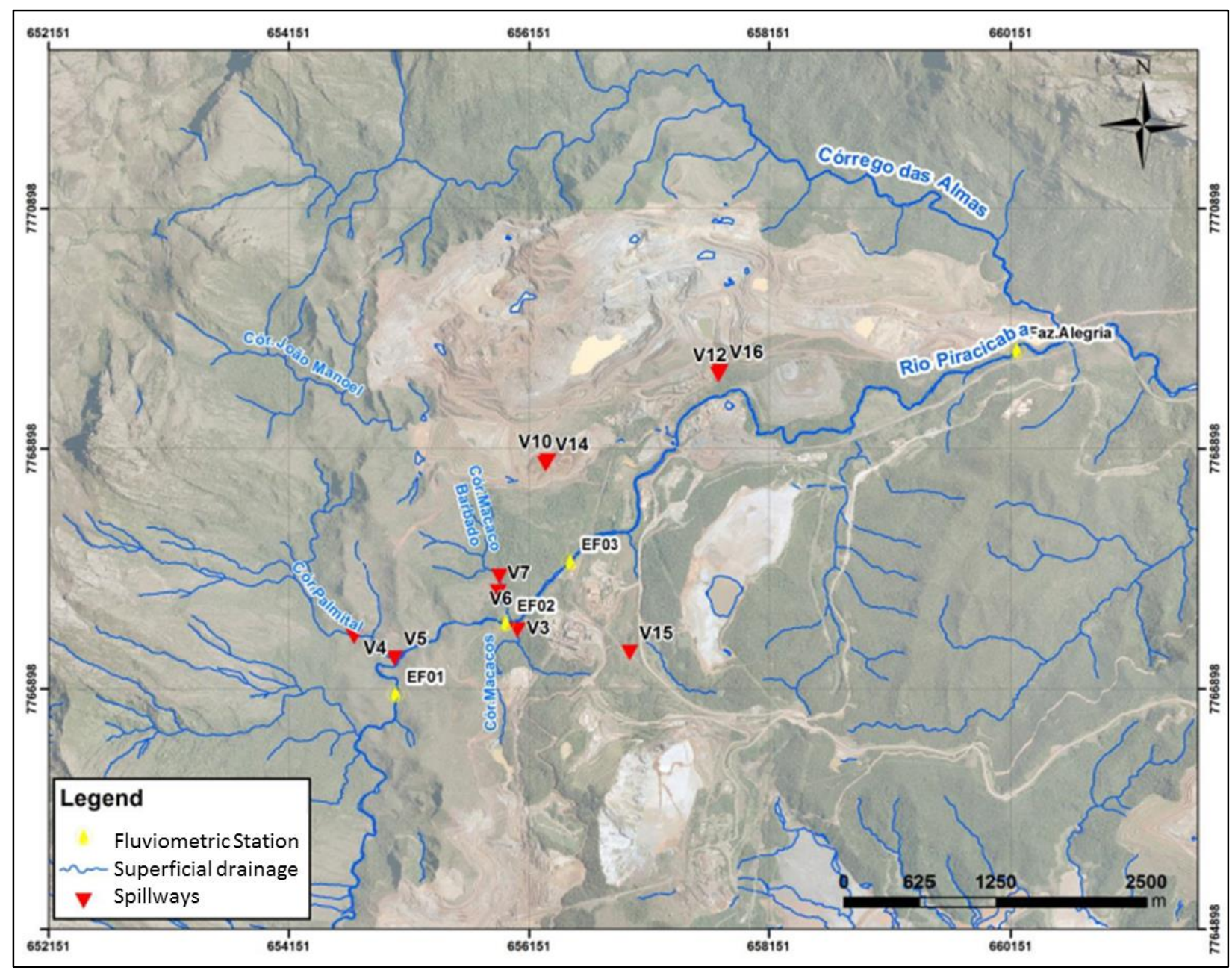

Figure 6 - Drainage network of Alegria Mina and Piracicaba sub-watershed

\subsection{References}

Alkmin, F.F.; Marshak, S., 1998: Transamazonian Orogeny in the Southern São Francisco Craton Region, Minas Gerais, Brazil: evidence for Paleoproterozoic collision and collapse in the Quadrilátero Ferrífero. Precambrian Research, v. 90, p.29-58.

Almeira, F.F.M. , 1977, O Cráton do São Francisco. Revista Brasileira de Geociências. São Paulo, 7(4):349-364;

Carneiro, M.A. , 1992, O complexo metamórfico Bonfim Setentrional (Quadrilátero Ferrífero, Minas Gerais): Litoestratigrafia e evolução geológica de um segmento de crosta continental do Arqueano. 1992. 233f. Tese (Doutorado em Geologia) - Universidade de São Paulo, São Paulo.

Mourão, M.A.A, 2007: Caracterização hidrogeológica do aquífero Cauê, 297 f., Tese (Doutorado) - Universidade Federal de Minas Gerais, Belo Horizonte. 
Noce, C.M., 1995. Geocronologia dos eventos magmáticos sedimentares e metamórficos na região do Quadrilátero Ferrífero, minas Gerais. Ph.D.Thesis, Instituto de Geociências, Universidade de São Paulo, São Paulo.

Renger, F. E.; Noce, C.M.; Romano, A.M.; Machado, N. Evolução Sedimentar do Supergrupo Minas: 500Ma de registro geológico no Quadrilátero Ferrífero, Minas Gerais, Brasil. Geonomos. Belo Horizonte, v.2, n.1, p.1-11, 1994.

Rocha, J. M. P., 2008, Definição da Tipologia e Caracterização Mineralógica e Microestrutural dos Itabiritos Anfibolíticos das Minas de Alegria da Samarco Mineração S.A. - Minas Gerais. Belo Horizonte: Escola de Engenharia da UFMG. 2vol. Tese de Doutorado apresentada ao Curso de Pós-Graduação em Engenharia Metalúrgica e de Minas da Universidade Federal de Minas Gerais, 460p.

Romano, A.W., 1989. Evolution Tectonique de la region norouest du Quadrilatere Ferrefer Minas Gerais - Brasil. Ph.D. Thesis, Université de Nancy. Nancy, France.

Silva, A. B. da; Sobreiro Neto, A. F.; Bertachini, A. C. Potencial das águas subterrâneas no Quadrilátero Ferrifero. In: CONG. BRAS. de AGUAS SUBTERRÂNEAS, 8, Recife, 1994. Anais. Recife: ABAS/DNPM/CPRM, 1994. p.264-283.

Veríssimo, C.U.V., 1999: Jazida de Alegria: Gênese e Tipologia dos Minérios de Ferro; Minas 3, 4 e 5 - Porção Ocidental. 2vol. Tese de Doutorado. Rio Claro: Instituto de Geociências e Ciências Exatas da Universidade Estadual Paulista. 


\subsection{Conceptual Geological and Hydrogeological Model}

Diversity of data was treated and spatially integrated in order to define the hydrogeological conceptual model, which considered hydroestratigraphic units, boundary conditions and aquifers hydraulic parameters.

The complex geological model of Alegria Mine was evaluated in main hydroestratigraphic units, defined by the treatment of data obtained from existing boreholes and pumping wells, using the softwares GEMS 6.7 (GEOVIA, 2015), Aquifer Test Pro 2014 and Visual Modflow Classic 2011, the last two developed by WATERLOO INC (2015).

Elaboration of the three-dimensional model of Alegria Mine involved the following steps: (1) domain's definition; (2) construction of the geological framework based on existing borehole data; (3) definition of surface drainage and monitoring, (4) distribution of hydraulic heads measured in monitoring campaigns, (5) spatial distribution of hydraulic conductivity $(\mathrm{K})$ and specific yield (Sy); and (6) effective recharge estimation.

\subsubsection{Domain's definition}

Definition of model's domain is dependent on the selection of external contours, being preferred those related to physical hydrogeological characteristics. The model domain defined based on known specific head and natural groundwater flow barriers, as surface water divides or impermeable barriers. No-flow condition occurs when the groundwater flow rate on the contour is zero and it can occur when the boundary is delimited by a rock with very low permeability. An important part of model design to simulate drawdown is the delimitation of domain and boundaries according to cone of depression range. If drawdown intercepts the boundaries with known head, it can force the model to produce an inappropriate result.

Using these concepts, Alegria Mine domain is limited by natural flow barriers in the bottom by Batatal Formation phyllites and on the top by Piracicaba Group phyllites and quartzites. In south part there are some intrusives dikes which delimitated the domain with an impermeable rock (ENDO, 1997). The depth of some parts of the model base required interpretation of itabirite and phyllites contacts. It ideally should coincide with a low-permeability formation, though it may not always be possible to define this in metamorphics rocks.

Therefore, as can be seen in figure 7, the domain of the conceptual model and boundary conditions are controlled by the lithological contacts of the Cauê aquifer with the base and top phyllites. The area of the model's domain has approximately $62 \mathrm{~km}^{2}$, with $10.5 \mathrm{~km}$ in a longitudinal axis and $6 \mathrm{~km}$ in the transversal axis. The surface of the model was defined using existing topographic data, followed by some observed and pumping wells. 


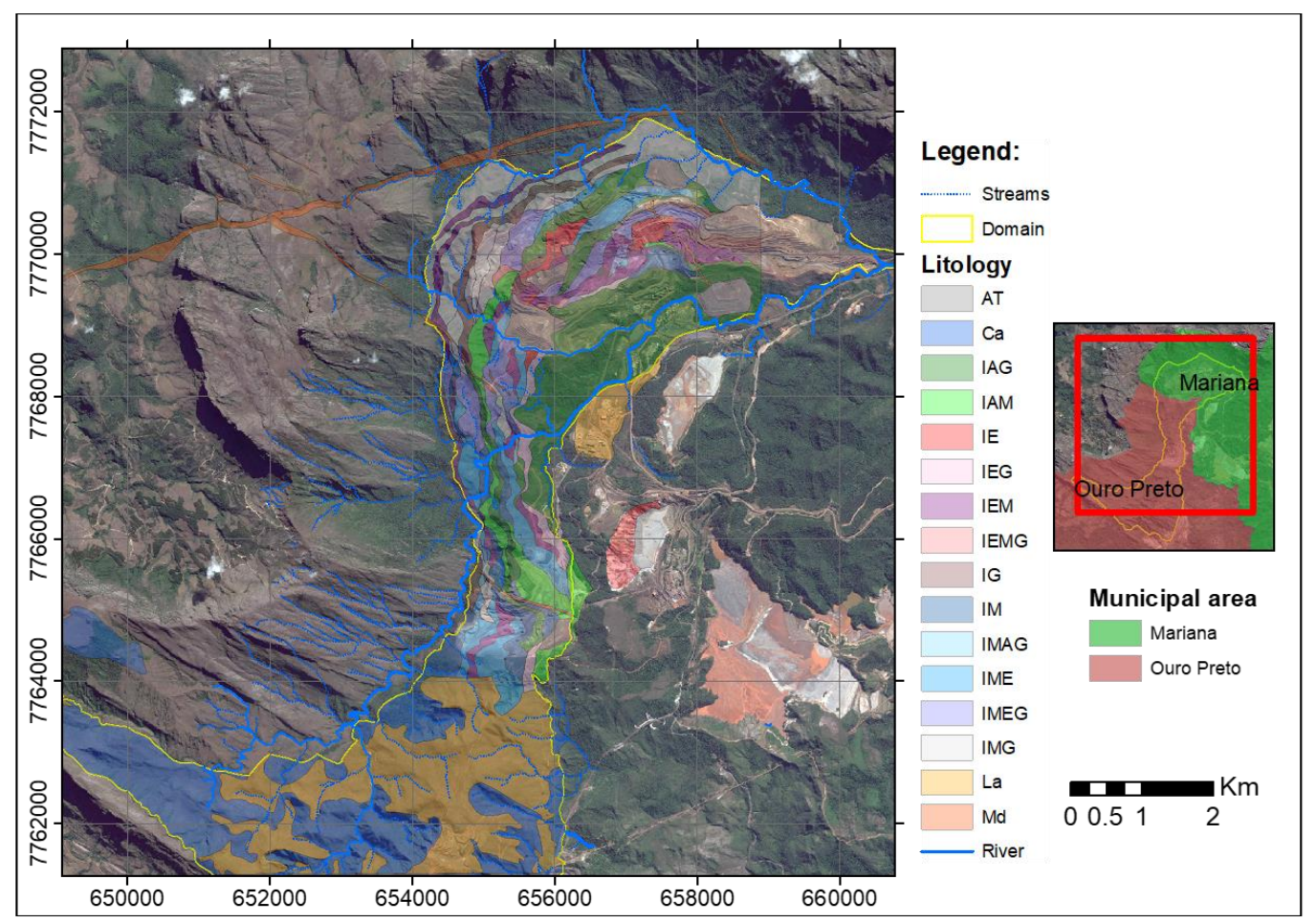

Figure 7 - Hydrogeological Domain

\subsubsection{Geological framework}

Using data from exploration boreholes of Samarco's survey campaigns and field works in Alegria Mine, the geological framework was grouped in a database. Therefore, using topographic and geological data were modeling using GEMS 6.7 software (GEOVIA, 2015).

Fieldwork was carried out throughout the development of this research and consisted of a systematic geological mapping in the scale 1:2,000. During this fieldwork were identified almost 1200 structural features (fractures and foliations). The main rock structures were used in ore body geometric definition and in the characterization of shear zones, which originate diferents types of itabirite. These structures are also important in the definition of more altered and more fractured zones, which are important indicators in the definition of the different hydrogeological units.

Exploration boreholes logging was carried out from diferents campaings from 2005 to 2012 , in a total of 1,623 drill holes. After logging, some samples were selected to laboratories, where petrographic and mineralogical analysis occurred under reflected light microscope. During the petrographic analyzes, an average of 500 crystals were accounted. In addition to collected data during field and laboratory work, the characterization of diferents types of itabirite was performed and then modeled using GEMS 6.7 software.

Initially vertical sections are made with borehole projection in the original topographt. The geological interpretation based on the mineralogical criteria characterizes the different lithological types, followed by the typological definition of the several itabirites. Once vertical section has been defined, the interpretation of horizontal sections is started, with a support of boreholes data. 
The stacking of horizontal sections is integrated into a three-dimensional solid model. However, there is a limitation in the elaboration of three-dimensional model, using extrusion method.

\subsubsection{Surface Drainage}

Flow monitoring allows the determination of the water volumes drained in rivers (Piracicaba and principal tributaries), streams and creeks (Figure 8). This type of data can be used as additional indicator to verify mass balance of the numerical model. Flow rates obtained by spillways, fluviometric stations and flowtracker measurements can be also processed in the processing of the numerical model of the study area. The streams and the Piracicaba River are perennial and will be inserted into the model with this classification.

Fluviometric spillways are devices used for the systematic flow rate monitoring. These structures are small barriers, constructed perpendicular to the watercourse, where pre-defined steel plates are installed, and the reading of the height of water that passes over these plates allows the estimation of the instantaneous flow rate at that section. They are simple and practical instruments to make measurements in springs, streams and small rivers. They are designed to quantify from 2 to $3 \mathrm{~L} / \mathrm{s}$ discharge to values of more than $100 \mathrm{~L} / \mathrm{s}$.

The spillways were located in order to monitor the base-flow in the study area and to associate the monitoring data to different aquifers (Figures 9- A and 9- B). Spillways monitored were in Macacos creek (V2 and V3), Palmital creek (V4 and V5) and Macaco Barbado creek (V6 and V7). The data monitored biweekly refer to the period between 2004-2016, which consists in a representative historical series, before and after the pumping wells start the drawdown in May 2006. 


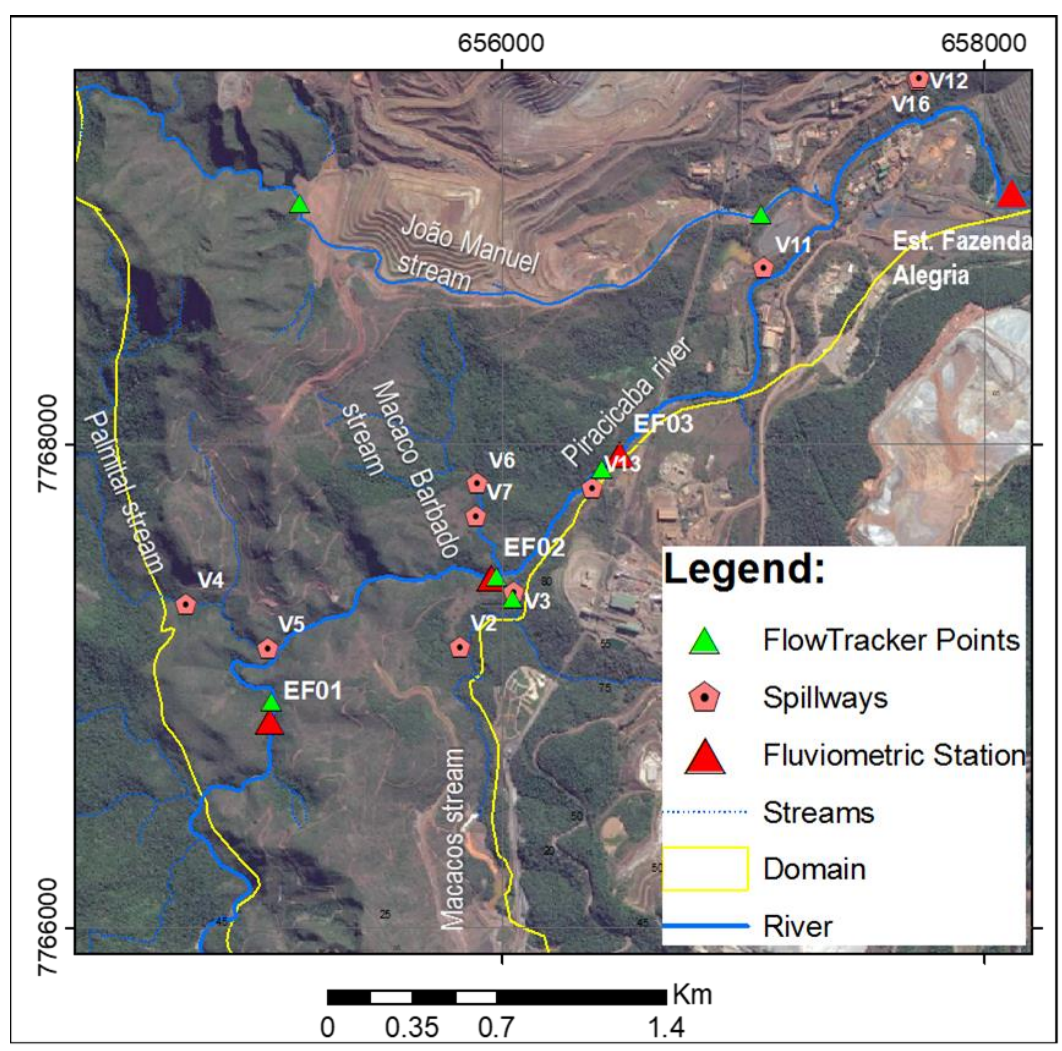

Figure 8 - Surface drainage monitoring map in the central area

Three automated fluviometric stations were employed to monitor Piracicaba River discharge. Station EF01 is located upstream in the based Cauê Formation geologic contact. Station EF02 in an intermediate zone, whose monitoring can evaluate the contribution of some springs and streams. In contrast, Station EF03 (Figure 9-C) is placed in the downstream zone where the Piracicaba River inflects E-W, dividing the mines of Alegria Center and Alegria South.

An automated fluviometric station consists of a set of linimetric rulers. There is an automatic pressure transducer datalogger on the riverbed to take measurements of the discharge every $30 \mathrm{~min}$. The monitoring campaigns comprised the periods between 2007-2011 and 20152016. Furthemore, monitoring data from "Fazenda Alegria" fluviometric station (Agencia Nacional de Águas, 2016) were also used in the conceptual hydrogeological model to verify water balance.

Flowtracker (SONTEK, 2011) is a flow meter that uses Acoustic Doppler Velocimeter (ADV) technology to measure velocities in two or three dimensions of a point located $10 \mathrm{~cm}$ apart from the acoustic transmitter. The discharge measurement is performed manually in watercourses up to $1 \mathrm{~m}$ deep (rivers, streams, tanks, channels, runoffs). This equipment can measure speeds from $0.001 \mathrm{~m} / \mathrm{s}$ to $4.5 \mathrm{~m} / \mathrm{s}$. Flow measurement using flowtracker is recommended for locations where it is not possible to install fluviometric spillways (Figure 9- D). Based on the depth, station width, and average speed, station discharge rate is calculated. Total flow is the sum of all the stations plus the discharge of each margin. 

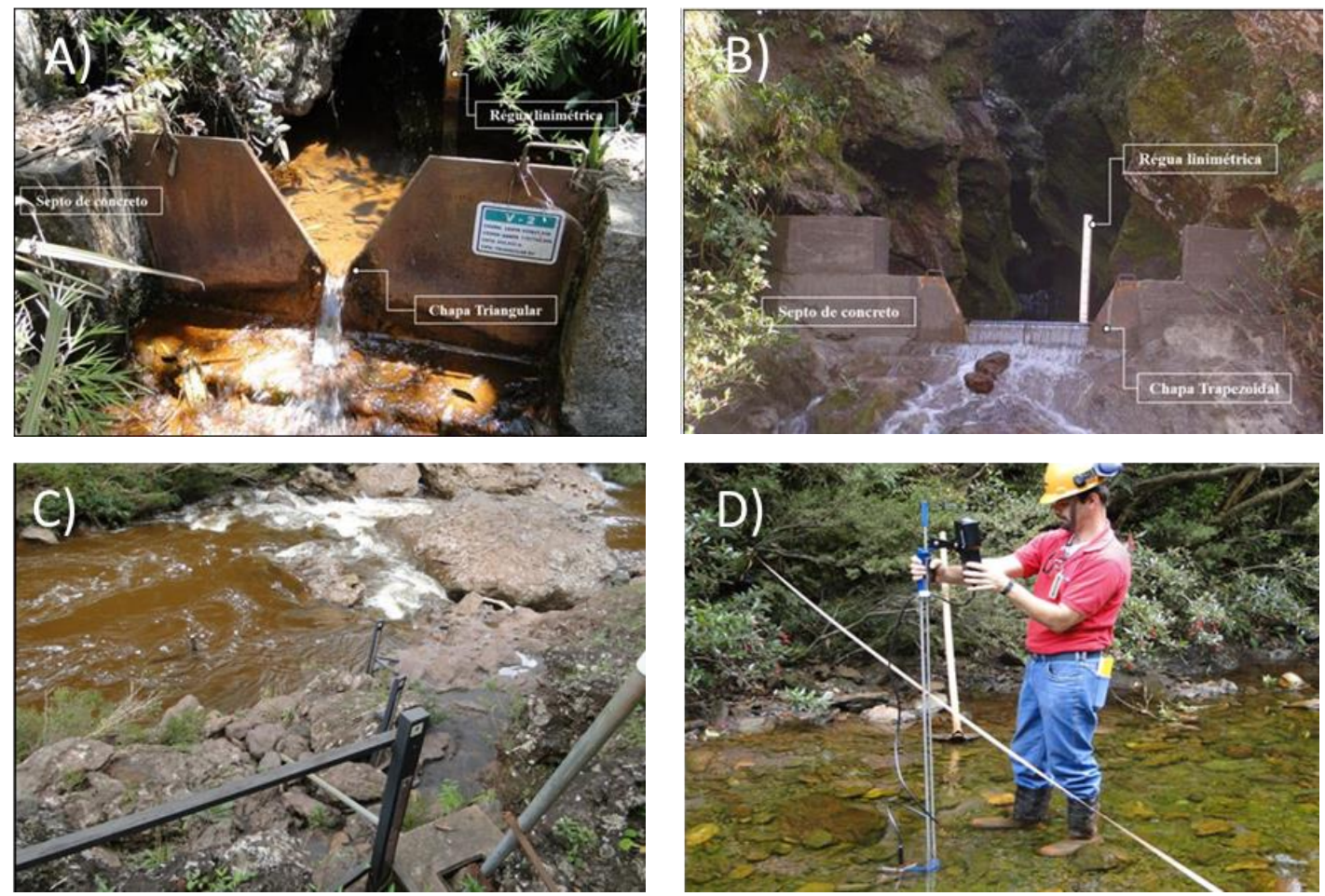

Figure 9 -Spillway in Alegria Mine with (A) Triangular shape; (B) Cipoletti shape; (C) Linnigraph EF03 in Alegria Mine and; (D) Flowtracker monitoring.

\subsubsection{Hydraulic Heads}

Observation wells are intended to provide hydraulic head measurements and to monitor water level variation due to climate changes or anthropic interference over time. These wells were built using rotary diamond drilling from past geological research campaigns. Some wells that were located on mining fronts were destroyed by detonations or during equipment transportation.

Approximately 80 observation wells were available for this study. They were evenly spread on Alegria Mine and monitored from June 2004 to July 2016. Currently there are only 37 active wells. According table 1 groundwater level in Alegria North were monitored using 36 observed wells (Figure 10). In Alegria Center (Table 2) and Alegria South (Table 3) were monitored 6 and 36 , respectively (Figure 11).

Measurements were taken manually (Figures 8- A and 8- C) with an electric water level meter Solinst model 101 twice a week or automatically over time with pressure transducers, which monitors groundwater level each 4 hours (Figures 8- B and 8-D). All data were used to generate equipotencial maps in real monitoring supervisor system using ArcGIS 10.1 (ESRI, 2011). 


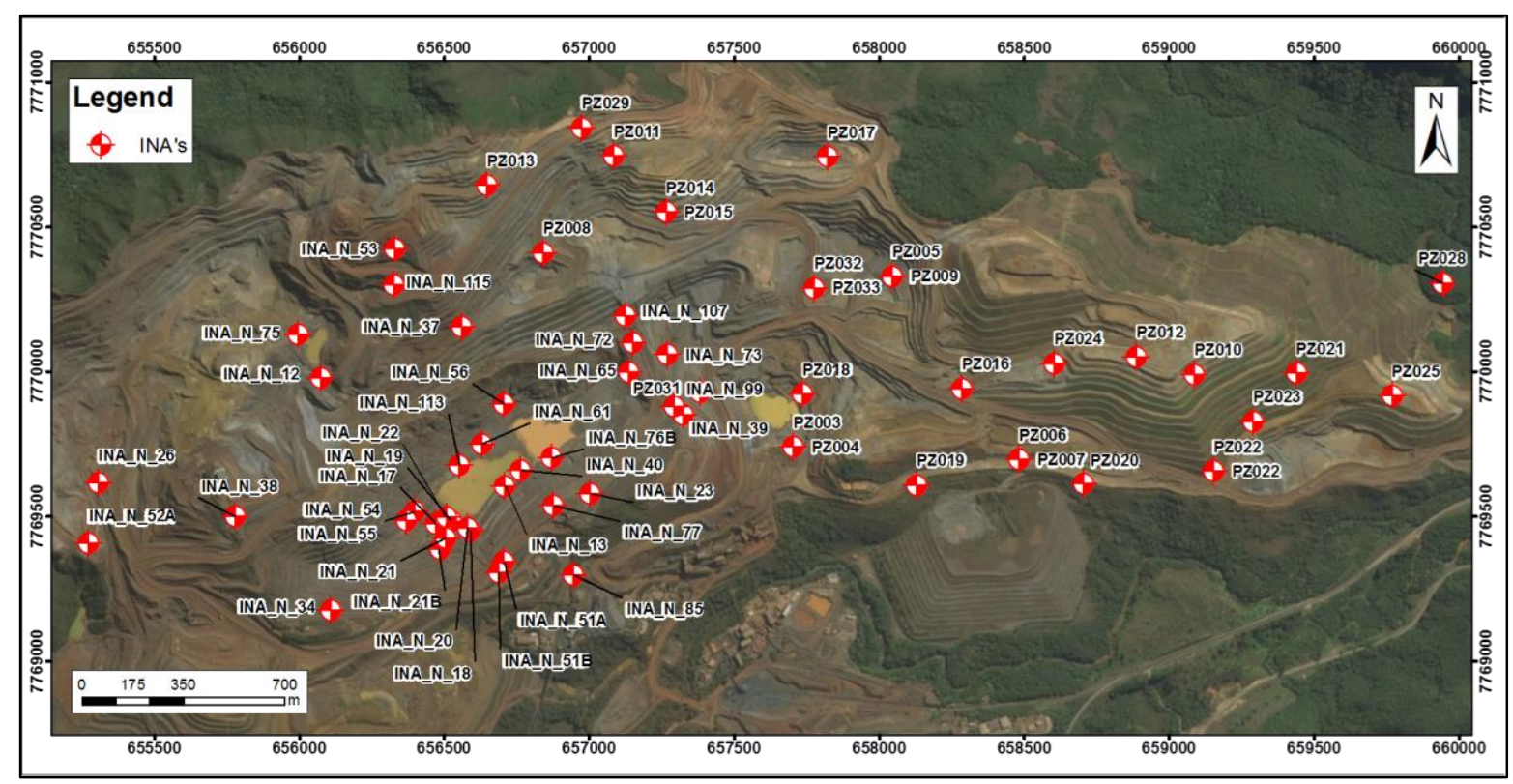

Figure 10 - Location Map of Monitoring Points in Alegria North

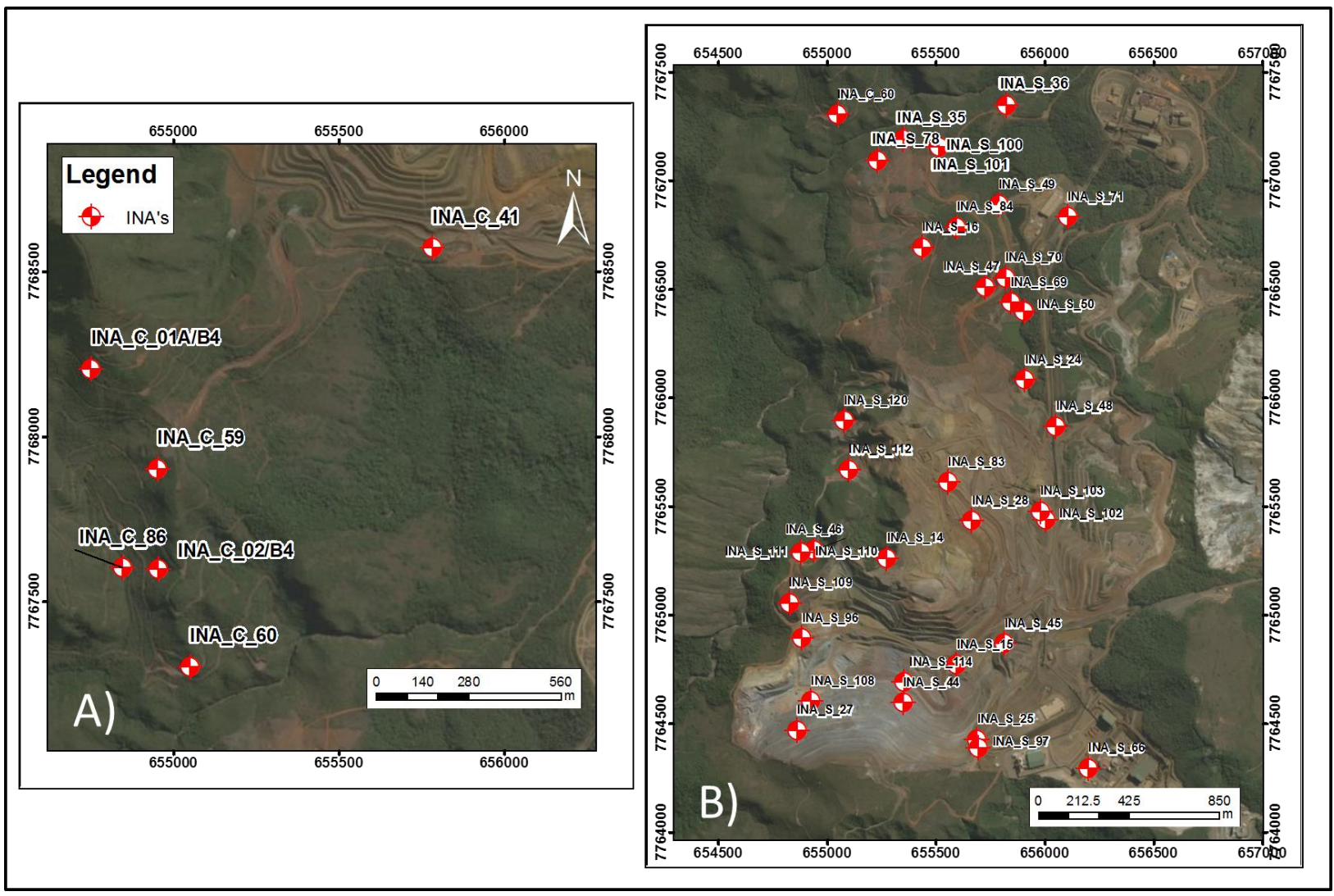

Figure 11 - Location Map of Monitoring Points in (A) Alegria Center and (B) Alegria South 
Table 1 - Observed well location in Alegria North.

\begin{tabular}{|c|c|c|c|c|c|c|}
\hline \multirow{2}{*}{ ID } & \multirow{2}{*}{ Installed } & \multirow{2}{*}{$\begin{array}{l}\text { Actual } \\
\text { Status }\end{array}$} & \multicolumn{2}{|c|}{ Location UTM SAD 69} & \multirow{2}{*}{$Z(m)$} & \multirow{2}{*}{ Depth $(m)$} \\
\hline & & & E-W & N-S & & \\
\hline INA_N_12 & Sep-03 & Inactive & 656075 & 7769977 & 1192 & 274 \\
\hline INA_N_13 & May-04 & Inactive & 656707 & 7769606 & 968 & 130 \\
\hline INA_N_17 & Sep-04 & Inactive & 656470 & 7769475 & 972 & 80 \\
\hline INA_N_18 & Sep-04 & Inactive & 656589 & 7769452 & 985 & 120 \\
\hline INA_N_19 & Aug-04 & Inactive & 656525 & 7769482 & 977 & 80 \\
\hline INA_N_20 & Sep-04 & Active & 656581 & 7769460 & 998 & 121 \\
\hline INA_N_21A & Oct-04 & Inactive & 656504 & 7769425 & 996 & 122 \\
\hline INA_N_21B & Oct-04 & Active & 656484 & 7769388 & 996 & 122 \\
\hline INA_N_22 & - & Active & 656509 & 7769497 & 971 & 81 \\
\hline INA_N_23 & Oct-04 & Inactive & 657004 & 7769579 & 1050 & 122 \\
\hline INA_N_26 & Feb-05 & Inactive & 655307 & 7769616 & 1190 & 260 \\
\hline INA_N_34 & Aug-06 & Active & 656108 & 7769177 & 1102 & 180 \\
\hline INA_N_37 & Aug-06 & Inactive & 656559 & 7770155 & 1173 & 250 \\
\hline INA_N_38 & May-07 & Active & 655779 & 7769500 & 1178 & 251 \\
\hline INA_N_39 & Dec-06 & Inactive & 657325 & 7769851 & 1038 & 150 \\
\hline INA_N_40 & Mar-07 & Inactive & 656764 & 7769660 & 983 & 80 \\
\hline INA_N_51A & Apr-07 & Active & 656706 & 7769343 & 1034 & 150 \\
\hline INA_N_51B & - & Active & 656687 & 7769306 & 1034 & 150 \\
\hline INA_N_52A & May-07 & Active & 655273 & 7769408 & 1124 & 200 \\
\hline INA_N_53 & Jun-07 & Inactive & 656330 & 7770424 & 1246 & 300 \\
\hline INA_N_54 & Jul-07 & Active & 656398 & 7769517 & 978 & 206 \\
\hline INA_N_55 & Jul-07 & Active & 656369 & 7769485 & 983 & 212 \\
\hline INA_N_56 & Aug-07 & Inactive & 656706 & 7769889 & 995 & 200 \\
\hline INA_N_61 & Jun-08 & Inactive & 656631 & 7769751 & 978 & 200 \\
\hline INA_N_65 & Nov-08 & Inactive & 657137 & 7769998 & 994 & 80 \\
\hline INA_N_72 & May-11 & Inactive & 657149 & 7770099 & 991 & 50 \\
\hline INA_N_73 & May-11 & Inactive & 657268 & 7770060 & 1039 & 250 \\
\hline INA_N_75 & - & Inactive & 655997 & 7770129 & 1179 & 220 \\
\hline INA_N_76B & - & Inactive & 656871 & 7769703 & 970 & 200 \\
\hline INA_N_77 & - & Inactive & 656877 & 7769538 & 1046 & 200 \\
\hline INA_N_85 & Mar-12 & Inactive & 656945 & 7769298 & 985 & 200 \\
\hline INA_N_99 & Dec-13 & Active & 657292 & 7769878 & 1022 & 127 \\
\hline INA_N_21 & Oct-04 & Inactive & 656504 & 7769425 & 996 & 122 \\
\hline INA_N_107 & Aug-15 & Active & 657125 & 7770193 & 1029 & 200 \\
\hline INA_N_115 & Sep-15 & Active & 656325 & 7770299 & 1216 & 300 \\
\hline INA_N_113 & Mar-16 & Active & 656553 & 7769677 & 980 & 70 \\
\hline
\end{tabular}

Table 2 - Observed well location in Alegria Center.

\begin{tabular}{|c|c|c|c|c|c|c|}
\hline \multirow{2}{*}{ ID } & \multirow{2}{*}{ Installed } & \multirow{2}{*}{ Status } & \multicolumn{2}{|c|}{ Location UTM SAD 69 } & \multirow{2}{*}{ Z (m) } & \multirow{2}{*}{ Depth (m) } \\
\cline { 4 - 5 } & & & E-W & N-S & & \\
\hline INA_C_01A/B4 & $24 / 05 / 2004$ & Inactive & 654750 & 7768206 & 1151 & 200 \\
\hline INA_C_02/B4 & $14 / 05 / 2004$ & Inactive & 654952 & 7767600 & 1039 & 100 \\
\hline
\end{tabular}




\begin{tabular}{|l|l|l|l|l|l|l|} 
INA_C_41 & $22 / 08 / 2006$ & Active & 655782 & 7768572 & 1054 & 151 \\
\hline INA_C_59 & $20 / 05 / 2008$ & Active & 654950 & 7767904 & 1105 & 190 \\
\hline INA_C_60 & $03 / 07 / 2008$ & Active & 655048 & 7767304 & 985 & 100 \\
\hline INA_C_86 & $18 / 04 / 2012$ & Active & 654846 & 7767603 & 1047 & 215 \\
\hline
\end{tabular}

Table 3 - Observed well location in Alegria South

\begin{tabular}{|c|c|c|c|c|c|c|}
\hline \multirow{2}{*}{ ID } & \multirow{2}{*}{ Installed } & \multirow{2}{*}{ Status } & \multicolumn{2}{|c|}{ Location UTM SAD 69} & \multirow{2}{*}{$Z(m)$} & \multirow{2}{*}{ Depth (m) } \\
\hline & & & $E-W$ & $\mathrm{~N}-\mathrm{S}$ & & \\
\hline INA_S_100 & - & Active & 655514 & 7767156 & 988 & 249 \\
\hline INA_S_101 & - & Active & 655514 & 7767156 & 988 & 188 \\
\hline INA_S_14 & $17 / 03 / 2004$ & Inactive & 655274 & 7765262 & 1203 & 180 \\
\hline INA_S_15 & $08 / 03 / 2004$ & Inactive & 655595 & 7764771 & 1130 & 211 \\
\hline INA_S_16 & $02 / 06 / 2004$ & Inactive & 655435 & 7766692 & 1051 & 120 \\
\hline INA_S_24 & $14 / 01 / 2005$ & Active & 655909 & 7766083 & 979 & 101 \\
\hline INA_S_25 & $10 / 02 / 2005$ & Inactive & 655689 & 7764427 & 1127 & 201 \\
\hline INA_S_27 & $18 / 03 / 2005$ & Inactive & 654861 & 7764470 & 1132 & 200 \\
\hline INA_S_28 & $06 / 06 / 2005$ & Inactive & 655665 & 7765435 & 1125 & 220 \\
\hline INA_S_35 & $30 / 06 / 2006$ & Active & 655350 & 7767191 & 986 & 100 \\
\hline INA_S_36 & $18 / 08 / 2006$ & Active & 655822 & 7767348 & 943 & 100 \\
\hline INA_S_44 & $31 / 05 / 2006$ & Inactive & 655348 & 7764597 & 1119 & 200 \\
\hline INA_S_45 & $08 / 06 / 2006$ & Inactive & 655815 & 7764868 & 1094 & 141 \\
\hline INA_S_46 & $30 / 06 / 2006$ & Inactive & 654939 & 7765299 & 1117 & 150 \\
\hline INA_S_47 & $10 / 07 / 2006$ & Inactive & 655727 & 7766511 & 991 & 100 \\
\hline INA_S_48 & $19 / 07 / 2006$ & Active & 656050 & 7765869 & 990 & 101 \\
\hline INA_S_49 & $29 / 09 / 2006$ & Inactive & 655788 & 7766891 & 984 & 129 \\
\hline INA_S_50 & $03 / 10 / 2006$ & Active & 655904 & 7766400 & 972 & 51 \\
\hline INA_S_66 & $19 / 02 / 2009$ & Inactive & 656200 & 7764294 & 1133 & 200 \\
\hline INA_S_69 & $15 / 10 / 2010$ & Active & 655842 & 7766438 & 966 & 200 \\
\hline INA_S_70 & $18 / 10 / 2010$ & Active & 655818 & 7766553 & 979 & 208 \\
\hline INA_S_71 & $25 / 04 / 2011$ & Inactive & 656105 & 7766835 & 989 & 25 \\
\hline INA_S_78 & $16 / 02 / 2012$ & Active & 655233 & 7767094 & 1005 & 200 \\
\hline INA_S_83 & - & Inactive & 655555 & 7765611 & 1105 & 260 \\
\hline INA_S_84 & - & Active & 655594 & 7766786 & 1054 & 260 \\
\hline INA_S_96 & $11 / 10 / 2013$ & Active & 654884 & 7764894 & 1100 & 200 \\
\hline INA_S_97 & $26 / 10 / 2013$ & Active & 655696 & 7764388 & 1128 & 250 \\
\hline INA_S_102 & $27 / 05 / 2014$ & Inactive & 656003 & 7765438 & 1055 & 200 \\
\hline INA_S_103 & $06 / 07 / 2014$ & Active & 655980 & 7765477 & 1054 & 200 \\
\hline INA_S_108 & $20 / 06 / 2015$ & Active & 654926 & 7764604 & 1070 & 200 \\
\hline INA_S_109 & $24 / 06 / 2015$ & Active & 654825 & 7765055 & 1122 & 80 \\
\hline INA_S_110 & $24 / 06 / 2015$ & Active & 654880 & 7765290 & 1126 & 32 \\
\hline INA_S_120 & $03 / 07 / 2015$ & Active & 655079 & 7765895 & 1084 & 130 \\
\hline INA_S_114 & $27 / 08 / 2015$ & Active & 655352 & 7764693 & 1029 & 200 \\
\hline INA_S_111 & $24 / 06 / 2015$ & Active & 654880 & 7765290 & 1125 & 10 \\
\hline INA_S_112 & $29 / 03 / 2016$ & Active & 655099 & 7765669 & 1125 & 108 \\
\hline
\end{tabular}



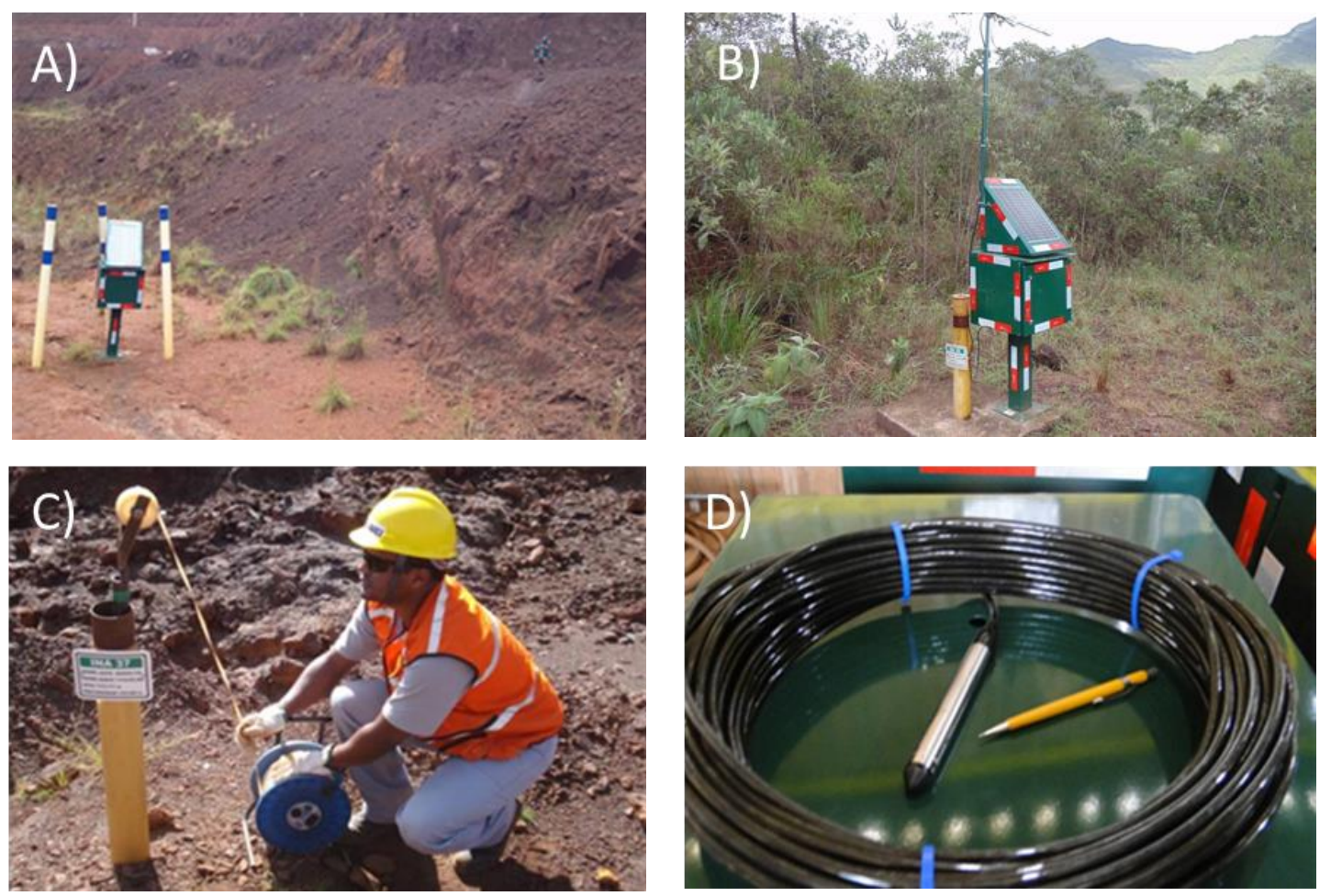

Figure 12 - (A) Observation wells in pit, (B) observed well out of pit; Water level measurement made (C) manually with Solinst equipment; (D) eletronic transdutors.

\subsubsection{Hydraulic Conductivity and Specific Yield}

Hydraulic parameters from different hydrogeological units were determined after analysis of the pumping tests in Aquifer Test Pro 2014 software (WATERLOO INC., 2015). Hydraulic Conductivity (K), specific storage (Ss) and Specific Yield (Sy) of the Cauê Aquifer (Figure 13) were evaluated by pumping and slug tests.

From Dupuit studies (1863, in FREEZE AND CHERRY, 1979), several authors formulated equations that reflect pumping tests in different types of aquifers. Interpretation of pumping tests was based an equation developed by Neuman (1975) since the study area is located in an unconfined and anisotropic aquifer.

In order to complement 9 pumping tests, 15 slug tests were performed in the observation wells, spatially distributed in the research area (Table 4). The pumping test consists of pumping at a constant flow rate during $48 \mathrm{~h}$ and observing, as a function of time, the decreases in the water level in the same pumping well and at some observations wells.

The data collected during pumping test were treated in spreadsheets, where it was possible to create log-log graphics. The constant flow, monitored throughout the test was also analysed to determine the descent curves of each well.

The Neuman model reproduces three segments of curve, in the form of $S$, being one of short time, one for intermediate times and another for the long times. The three curve segments can be understood by the following explanation: 
- The short time inclined segment covers only a brief period after the start of pumping. In this interval, an unconfined aquifer reacts in a similar way to a confined aquifer, that is, the pumping is basically preventive of the water expansion and aquifer compaction. This segment time is similar to curve of Theis and it is possible to determine Ss.

- The stable segment of intermediate times reflects the effect of the drainage that accompanies drawdown. The effects of aquifer drainage during drawdown determines Sy.

- The relatively long-leaning segment reflects the situation where the curve $s \times t$ resembles, thereafter, to Theis curve again. This segment occurs in regions without direct recharge.

Table 4 - Pumping well location in Alegria Mine

\begin{tabular}{|c|c|c|c|c|c|c|}
\hline \multirow{2}{*}{ ID } & \multirow{2}{*}{ Location } & \multicolumn{2}{|c|}{ UTM SAD 69 } & \multirow{2}{*}{ Installed } & $\begin{array}{c}\text { Active } \\
\text { months }\end{array}$ & $\begin{array}{c}\text { Pumping } \\
\text { test (time) }\end{array}$ \\
\cline { 3 - 6 } & Alegria North & 656533 & 7769414 & jun/06 & 50 & 48 \\
\hline PTR_N_01 & Alegria North & 656652 & 7769456 & mai/08 & 56 & 48 \\
\hline PTR_N_02 & Alegria North & 656406 & 7769513 & mai/08 & 61 & 48 \\
\hline PTR_N_03 & Alegria South & 655819 & 7766464 & nov/12 & 40 & 48 \\
\hline PTR_S_04 & Alegria South & 655817 & 7766721 & mai/12 & 40 & 48 \\
\hline PTR_S_05 & Alegria North & 656749 & 7769634 & $\mathrm{mar} / 13$ & 16 & 48 \\
\hline PTR_N_06 & Alegria North & 656529 & 7769675 & $\mathrm{nov} / 13$ & 27 & 48 \\
\hline PTR_N_07 & Alegria South & 655438 & 7766899 & $\mathrm{mar} / 14$ & 28 & 48 \\
\hline PTR_S_08 & Alegria North (Vale) & 658517 & 7769997 & $\mathrm{abr} / 10$ & 31 & 24 \\
\hline PALR-01 & Al & & & & 48 \\
\hline
\end{tabular}

The principle of the slug test is the point estimate of $\mathrm{K}$ with the instantaneous change of water level in observed wells. Concerning to determine the parameters and hydraulic propertie of aquifers, pumping and slug tests were used to conceptual and numerical build in Alegria Mine. 


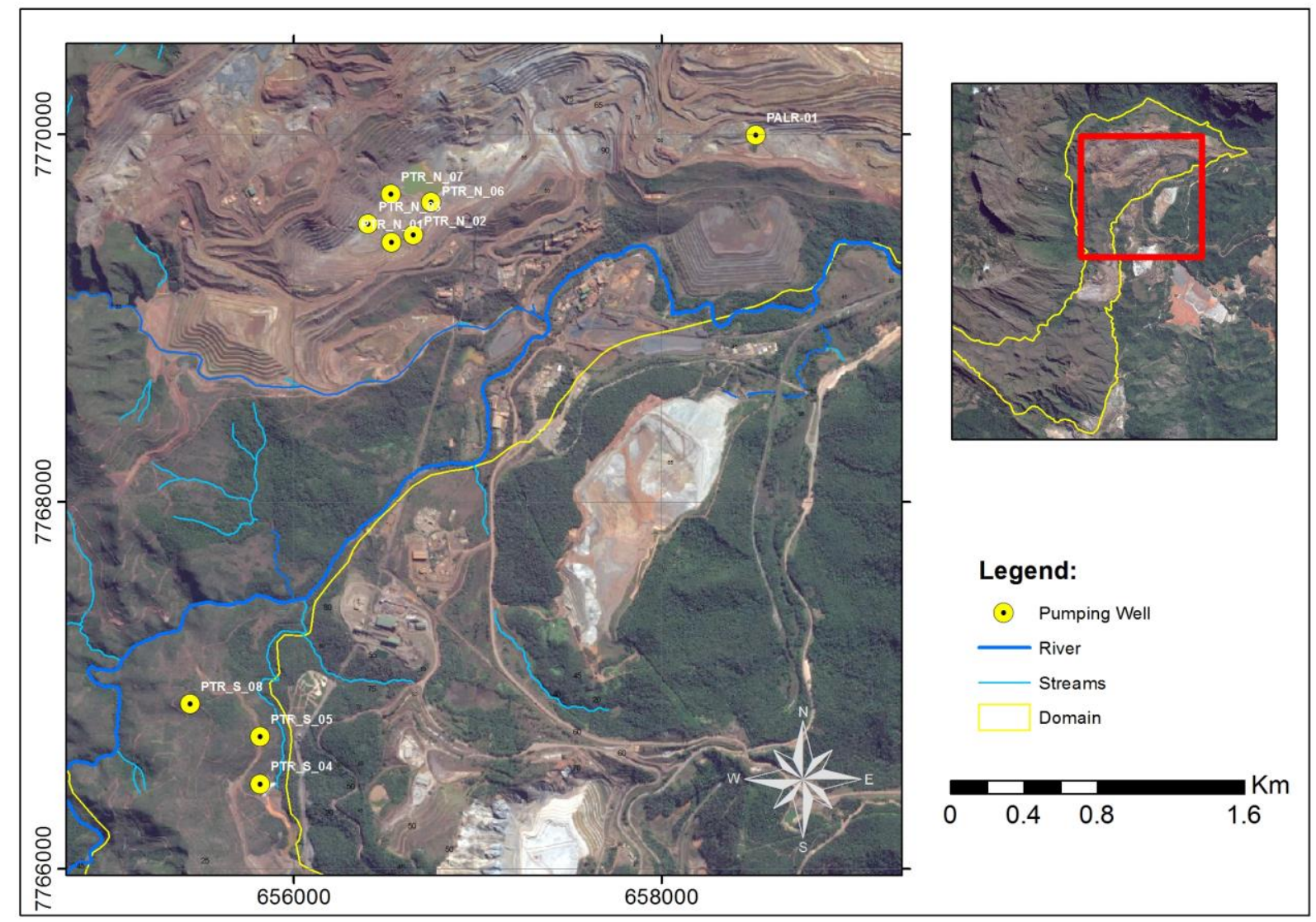

Figure 13 - Pumping wells located in Cauê Aquifer, east part of Quadrilátero Ferrífero

\subsubsection{Effective Recharge Estimation}

According to Freeze and Cherry (1979), aquifer recharge is defined by the inflow of water towards the saturated zone. This definition does not exclude contributions from lateral flows to the aquifer reservoir. However, this parameter is generally the least known in an aquifer, and cannot be measured on a reasonable spatial scale.

In order to determine the influence of the open pits as recharge structures in Cauê Aquifer, Bertachini et al. (2012) compared the recharges studies of Cauê Aquifer in the excavate areas by the mining with others with natural topography. For the areas topographically undisturbed, recharge lied between $35 \%$ and $40 \%$ of total precipitation. Applying the same method to the exhausted Capanema Iron Mine, recharge was estimated as $84 \%$ of annual precipitation.

Mourão (2007) determined the effective recharge of several hydrogeological units for the east part of the Quadriláteo Ferrífero. Statistical and spatial methods were used to define the dominant types of rocks of each microbasin, and different proportions of recharge were associated according to dominant rock type. Quartzites and dolomites presented recharge values below $28 \%$ of annual precipitation. The effective recharge for unconfined Cauê Aquifer is up to $38 \%$. 
Precipitation and potential evapotranspiration data were collected at five weather stations WeatherHawk Model 232 at Alegria Mine. Meteorological station consists of several sensors to measure the following parameters: temperature, wind direction, wind speed, solar radiation, atmospheric pressure, relative air humidity and calculated evapotranspiration (ETo). Potential evapotranspiration is calculated in a metheorological station with the Penman-Monteith method (ALLEN et al., 1998). Data is stored in datalogger and can be downloaded using a laptop. In addition to meteorological stations, manual rain gauges were also used to verify consistency of the automated instruments. All data in this study were used to calculate the effectivie recharge using hydrograms and water balance interpretation.
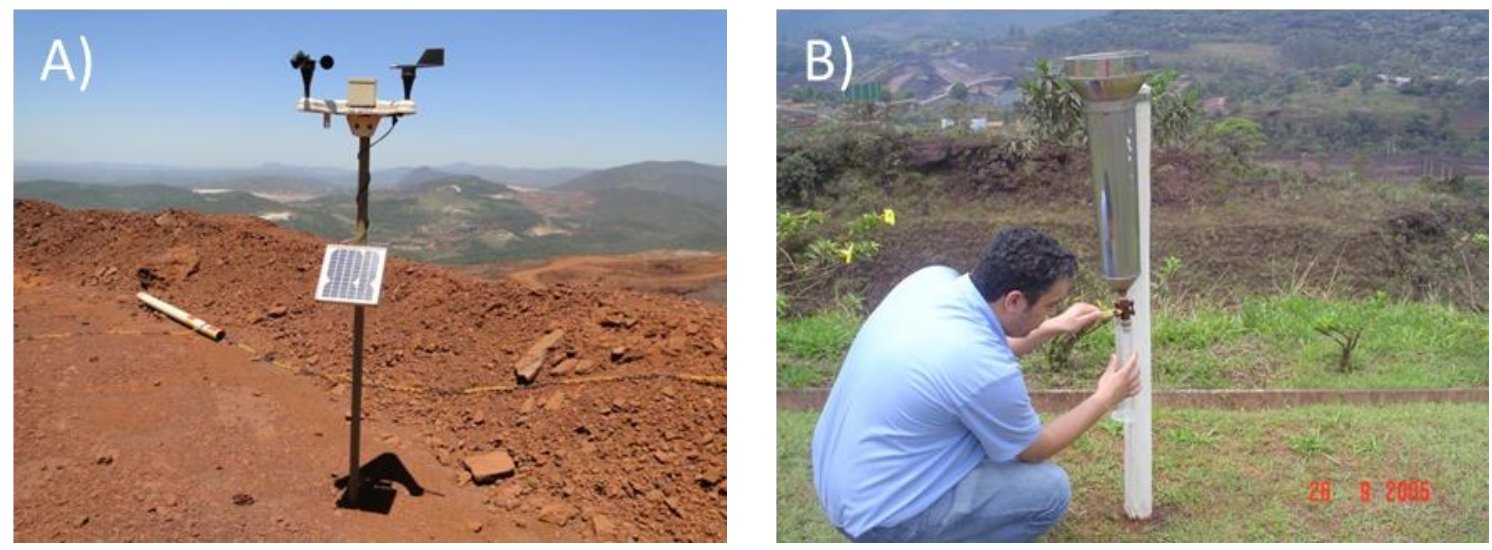

Figure 14 - (A) Weatherhawk automatic station; (B) Ville de Paris pluviometer.

\subsection{Numerical Hydrogeological Model}

Even though numerical modeling method is described in detail in Chapter 7, the main steps involved in modeling - spatial discretization, calibration and sensitivity analysis - are briefly presented in the following.

\subsubsection{Spatial discretization}

Dimensions of the conceptual model should be evaluated for the calculation of the finite difference cell sizes required to converge the numerical solve to obtain the result with appropriate resolution. Mesh grid orientation can be chosen to minimize the numerical dispersion and computational capacity required. Changes in the distance between adjacent rows in the mesh should never exceed a factor of 2 (ANDERSON e WOESSER, 2011).

\subsubsection{Calibration}

Calibration of the groundwater flow model demonstrates the ability to reproduce numerical hydraulic head and flow measurements in concordance with observed data. To validate the model calibration it is necessary to check the mass balance and the discrepancy between calculated 
and observed hydraulic heads. Mass balance errors should not be greater than $1 \%$ and calibration error, in form of standardized root mean square (RMS), should be less than $10 \%$, taking into account good modeling practices (SPITZ AND MORENO, 1996).

To achieve the calibration process, the modeler can change the parameters manually (traditional) or automatically. Manual change means to change values in a gradational way until the expected calibration is acceptable. Automatic change can be performed in an auxiliary way, using a non-linear parameter estimation program such as DOHERTY and HUNT (2009), also known as Parameter Estimator (PEST).

\subsubsection{Sensitivity analysis}

The purpose of the sensitivity analysis is to determine the uncertainty related to parameters and boundary conditions, obtained in calibration process. The major objective is to identify which parameters have the greatest influence on the calibration error. This step is important to leave numerical model defensible with respect to the uncertainties of the parameters that exist in a real scale.

During the sensitivity analysis, calibration values are evaluated whereas hydraulic conductivity values are changed within a plausible range. However, some parameter combinations can be performed to achieve the same result. For example, Mandle and Kontis (1986) simulated changes in hydraulic conductivity and river conductance to determine the influence of these parameters calibration error.

\section{References}

Allen, R.G., Pereira, L.S., Raes, D., 1998. Crop evapotranspiration Rome: FAO, 1998. 297p

Anderson, M.P., Woessner, W.W., 2002, Applied groundwater modeling: simulation of flow and advective transport. San Diego, California, 381p

Bertachini, M.N.A, Bertachini, A.C, Pereira, B.A., Grandchamp, C.A., Nunes, F., Pereira Filho, M.P., 2012. Estudos sobre os efeitos da recarga artificial (RA) sobre o Aquífero Cauê, no Quadrilátero FerríferoMG., XVII Congresso Brasileiro de Águas Subterrâneas e XVIII Encontro Nacional de Perfuradores de Poços. Belo Horizonte.

Doherty, J. and Hunt, R.J., 2009. Two easily calculated statistics for evaluating parameter identifiability and error reduction. Journal of Hydrology. 366, 119-127.

Endo, I., 1997. Regimes Tectônicos do Arqueano e Proterozóico no Interior da Placa Sanfranciscana: Quadrilátero Ferrífero e áreas adjacentes, Minas Gerais. 1997. 243 f. Tese (Doutoramento em Geoquímica e Geotectônica) - Instituto de Geociências, Universidade de São Paulo.

ESRI, 2011. ArcGIS Desktop: Release 10. Redlands, CA: Environmental Systems Research Institute.

Freeze, R.A., Cherry, J.A., 1979: Groundwater. Prentice Hall Inc., NJ, USA.

GEOVIA, 2015, Software GEMS 6.7, 20Vancouver, B.C., Canada, V6E 3X1. 
Mandle, R.J., and Kontis, A.L., 1986. Directions and rates of ground-water movement in the vicinity of Kesterson Reservouir, San Joaquin Valley, California, USGS, Water-Resources Investigations Report 86-4196, $57 \mathrm{p}$.

Neuman, S.P., 1975 - Analysis of pumping test data from anisotropic unconfined aquifers considering delayed gravity response. Water Resource., 11 pags: 329-342.

SONTEK, 2011, Flowtracker Brochures handheld-ADV-1, FlowTracker and SmartPulseHD trademarks of Xylem Inc. or one of its subsidiaries., USA.

Spitz, K,Moreno, J., 1996. A Practical Guide to Groundwater and Solute Transport Modeling, Wiley, EUA

Waterloo INC, Software Visual Modflor 2011, built 4.6.0.168 and Aquifer Test Pro 2014, Waterloo, Canada. 


\title{
CHAPTER 4 - HYDROGEOLOGICAL MODELING APPLIED FOR MINE PLANNING - CUT-OFF WALLS SIMULATIONS FOR A HYPOTHETICAL SCENARIO
}

João Paulo Chiste-Costa, Alexandra Vieira Suhogusoff, Luiz Carlos Ferrari

\begin{abstract}
The level of effort required at each stage in a mine's dewatering project is complex, with high costs and operational interventions. A large number of techniques and methods are used to develop the mine operation below water level, such as pumping wells and cut-off walls. A numerical hydrogeological simulation can demonstrate groundwater over-exploitation effects on mine advances, making possible to plan actions for mining operation in long-term. This paper presents cut-off barrier behavior under development of a cone of depression close to a river in a numerical groundwater flow model. In that case the sustained dewatering pumping without cutoff walls decreased the potential regional groundwater levels in aquifer, and reduced the river flow-rate. Simulation results showed that temporary cut-off walls aplication can reduce the water impact on a superficial drainage and keep the river flow rate in $25 \%$. This paper also reports the importance of hydrogeological modeling in conjunction with mine planning in order to reduce operational costs, to solve geotechnical issues, to mitigate environmental impacts and to increase capability the ore reserve.
\end{abstract}

\section{Introduction}

In many mines, water table drawdown is mandatory to access ore reserves. Normally, water volumes exploited in mines are far superior to ore extraction itself. Hydrogeological models are important tools in predicting mining challenges and quantifying pumping wells and total flowrate required to feasibility of the ore reserve. Modeling studies are generally strategic and they should be conducted in mine planning, from the mineral exploration phase (pre-mining), during the mining operation and in the mine closure plan (post-mining).

Water table drawdown is a practice that directly interferes in natural aquifer conditions and superficial drainage. The hypothetical numerical groundwater model presented in this paper shows the impacts caused by the evolution of a cone of depression over a river. On a second step, model presents simulation results obtained with the implementation of cut-off barriers close to the river, under dry season, as alternative to minimize deleterious hydrological effects created by drawdown. This situation is quite common with mining companies that deal with ore exploration in tropical regions, where water levels are usually shallow.

To deal with some technical concepts, a briefly explanation of Darcy's law, Hubert's Force and Laplace Equation Potencial and Laplace's Equation will be described in this section. 


\section{Groundwater Modeling Concepts}

A model is an instrument, scheme, or procedure typically used in systems analysis to predict the consequences in the real phenomena. This model intends to represent the real world in diferents steps and scale. Several models are applied to the understanding of physical process. Among several models, the hydrogeological models tend to represent the behavior of the groundwater flow in a porous or fractured medium.

The mathematical hydrogeological models consist of differential equations configuration that translate the behavior of groundwater flow. The application of numerical methods for problems related to groundwater flow is a solution to solve problems of steady and transient flows in porous media.

\subsection{Darcy's Law}

A series of experiments performed by Darcy (FREEZE AND CHERRY, 1979) established that a type of material located inside a cylinder the discharge flow $Q$ is directly proportional to the head drop $h_{2}-h_{1}$ of section with area $A$, but inversely proportional to the length of the tube $\left(I_{2}\right.$ $\mathrm{I}_{1}$ ). The proportionality constant $\mathrm{K}$ is called hydraulic conductivity and the negative sign means that the direction of head loss.

$$
Q=-K A \frac{h_{2}-h_{1}}{l_{2}-l_{1}} ;(\text { Eq. 1) }
$$

Groundwater flows in response to hydraulic gradient or pressure differences that it is described by Hubbert's Force Potentital.

\subsection{Hubbert's Force Potential}

A unit volume of water in the aquifer can be characterized by a state of energy, governed basically by the acting forces: gravitational and kinetic. Hubbert (1940) defined the concept of total potential of water as the energy required to carry a volume of water from the initial reference to another point. The difference in potential energy is the engine that moves water into an aquifer governed by elevation and pressure. The required work $W_{1}$ to increase the water pressure is given by equation below:

$$
W_{1}=m \int_{0}^{P} \frac{V}{m} d P=m \int_{P 0}^{P} d P / \rho ; \quad \text { (Eq. 2) }
$$

Where $m=$ mass and $V=$ volume of water. It should be noted that volume $V$ is $m / \rho(\rho=$ water density), replacing the variables in equation 2. Assuming that water is incompressible and 
density is equal on all pressures, the solution of equation 2 indicates that the work required to raise the water pressure will be $\left(\mathrm{P}-\mathrm{P}_{0}\right) / \rho$.

In contrast, the required work $\mathrm{W}_{2}$ to raise the mass of water is given by the acceleration of gravity $g$ and by the elevation $z$, according to the equation below:

$$
W_{2}=m g z ;(\text { Eq. 3) }
$$

Total Potential $\theta$ can be defined by the sum of $\mathrm{W} 1$ and $\mathrm{W} 2$. To simplify the solution, it is assumed that the water mass is a unit value $(m=1)$. Therefore, the equation will be:

$$
\theta=g z+\frac{p-p_{0}}{\rho} ;(\text { Eq. } 4)
$$

Note that at point $P$ (Figure 15) the fluid pressure $p$ is the weight of the liquid column $\Psi$ and the atmospheric pressure $p_{0}$ :

$$
p=\rho g \Psi+p_{0} ;(\text { Eq. } 5)
$$

Knowing that there exists a spatial relation of $\mathrm{h}$ between $\Psi$ and the reference base $\mathrm{z}$ :

$$
p=\rho g(h-z)+p_{0} ;(\text { Eq. } 6)
$$

Substituting equation 4 by equation 6 :

$$
\theta=g z+\frac{\left(\rho g(h-z)+p_{0}\right)-p_{0}}{\rho} \quad \text { or } \quad \theta=\rho g(h-z) ;(\text { Eq. } 7)
$$

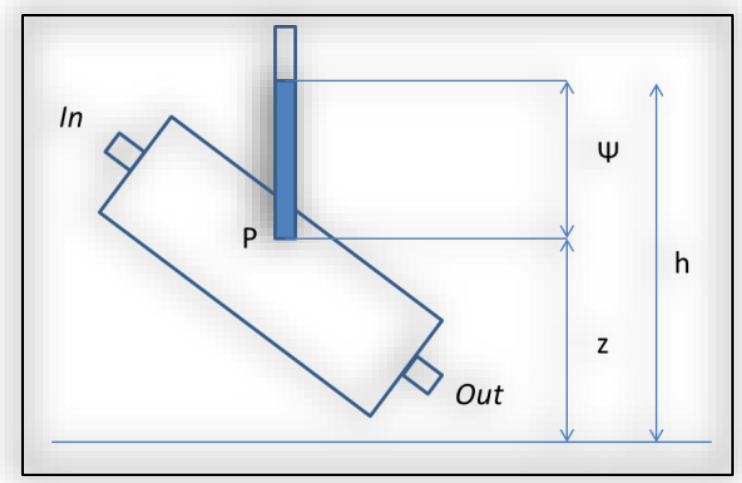

Figure 15 - Darcy's experiment with hydraulic head references and pressure on point $P$. 
If the reference point $z$ is the sea level (dimension $=z=0$ ), equation 7 is simplified for $\theta=\mathrm{gh}$, assuming water density is constant $\left(1 \mathrm{~g} / \mathrm{cm}^{3}\right)$. In this case, Darcy's Law demonstrates that the groundwater moves towards the directions of the energy decay (FETTER, 1994).

\subsection{Continuity Equation and Laplace's Solution}

An elemental volume, also known in the literature (FREEZE AND CHERRY, 1979; ANDERSON \& WOESSNER, 2011) by representative elementary volume (REV), can represent a volume that has all the characteristics of the aquifer, including its homogeneity/heterogeneity and isotropy/anisotropy. The REV is an infinitesimal cube with equal faces in all three directions (Figure 16), where groundwater will be transmitted.

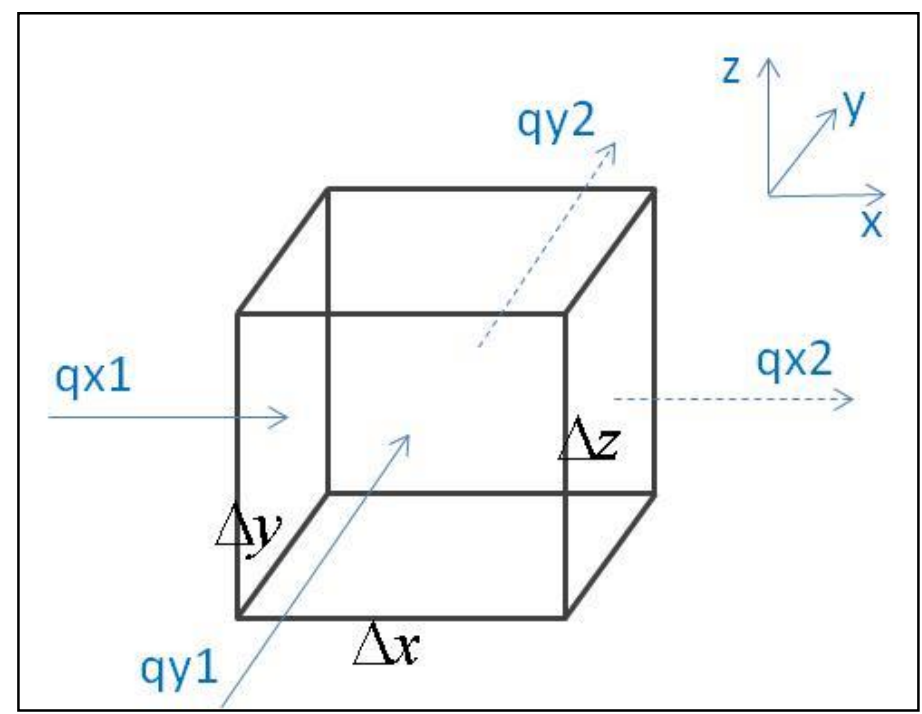

Figure 16 - Representative Elementar Volume (REV) used to derive the continuity equation.

The concept of inflow and outflow of water into a REV is based the principle of mass conservation. The fundamental assumption of the principle of mass conservation indicates that the result has to be continuous over time and space. For steady-state regime, continuity requires that the amount of water flowing into a REV be equal to the amount flowing out. In this case, the mass balance (input - output) must be zero. However, if there is a diferent water balance into a REV and there is variation of hydraulic head as a function of time, it defines the transient regime. Transient regime is also know time depende or nonsteady-state problems.

Applying principle of mass conservation in REV we observe the inflow and outflow in three dimensions $[\mathrm{L} / \mathrm{T}]$, given by qx, qy and qz. In this case, the volume of water flowing through the REV sections can be given by: 


$$
\begin{array}{ccc}
q x_{1} \Delta y \Delta z & e & q x_{2} \Delta y \Delta z \\
q y_{1} \Delta x \Delta z & \text { e } & q y_{2} \Delta x \Delta z \\
q z_{1} \Delta x \Delta y & \text { e } & q z_{2} \Delta x \Delta y
\end{array}
$$

Combining Darcy's Law with the principle of mass conservation, we obtain a recognized partial differential flow Laplace equation (FREEZE AND CHERRY, 1979). According to Darcy's Law, we have:

$$
q_{l}=-K \frac{\delta h}{\delta l} \quad(\text { Eq.9) }
$$

where: $q=$ Darcy's flow $[\mathrm{L} / \mathrm{T}] ; \mathrm{K}=$ hydraulic conductivity $[\mathrm{L} / \mathrm{T}] ;$ סh = head difference $(\mathrm{h} 1-\mathrm{h} 2)[\mathrm{L}]$ and $\delta \mathrm{l}=$ length or distance in the $\mathrm{x}, \mathrm{y}$ and $\mathrm{z}$ direction [L].

In transient regime, we have:

$$
\left(q x_{2}-q x_{1}\right) \Delta y \Delta z+\left(q y_{2}-q y_{1}\right) \Delta x \Delta z+\left(q z_{2}-q z_{1}\right) \Delta x \Delta y=\text { storage change (Eq.10) }
$$

In steady-state flow, the second term of equation 10 will be zero. In this case, it is assumed that the water inlet is equal to the water outlet, with no storage changes and variations of the hydraulic head over time. The continuous regime equation will be:

$$
\left(q x_{2}-q x_{1}\right) \Delta y \Delta z+\left(q y_{2}-q y_{1}\right) \Delta x \Delta z+\left(q z_{2}-q z_{1}\right) \Delta x \Delta y=0
$$

Dividing equation 10 by the elementary volume $\Delta \mathrm{x} . \Delta \mathrm{y} . \Delta \mathrm{z}$ gives:

$$
\frac{\Delta q x}{\Delta x}+\frac{\Delta q y}{\Delta y}+\frac{\Delta q z}{\Delta z}=\frac{\text { mudanças do armazenamento }}{\Delta x \Delta y \Delta z}
$$

The right-hand side of equation 12 shows that the storage change $\Delta \mathrm{V}$ is represented by the specific storage Ss, which is defined by the volume change as a function of different heads along the time.

$$
\frac{\Delta V}{\Delta t}=-S s \frac{\Delta h}{\Delta t} \Delta h \Delta x \Delta y \Delta z(\text { Eq.13) }
$$

Using equations 12 and 13 into infinitesimal dimensions with inflow or outflow in the aquifer the variable adds a pumping well or recharge constant $\mathrm{Qv}$ (flow per unit volume):

$$
\frac{\partial q x}{\partial x}+\frac{\partial q y}{\partial y}+\frac{\partial q z}{\partial z}=-S_{S} \frac{\partial h}{\partial t} \pm Q_{v}
$$


Applying Darcy's law (eq. 8) in equation 14:

$$
\frac{\partial}{\partial x}\left(K_{x} h \frac{\partial h}{\partial x}\right)+\frac{\partial}{\partial y}\left(K_{y} h \frac{\partial h}{\partial y}\right)+\frac{\partial}{\partial z}\left(K_{z} h \frac{\partial h}{\partial z}\right)=-S_{s} \frac{\partial h}{\partial t} \pm Q_{v}
$$

And assuming that the medium is homogeneous and isotropic with respect to $\mathrm{K}$, the equation 15 can be solve Laplace's solution:

Steady-State Satured Flow:

$$
\frac{\partial^{2} h}{\partial x^{2}}+\frac{\partial^{2} h}{\partial y^{2}}+\frac{\partial^{2} h}{\partial z^{2}}=-S_{s} \frac{\partial h}{\partial t}+Q_{v}
$$

Transient Saturated Flow:

$$
\frac{\partial^{2} h}{\partial x^{2}}+\frac{\partial^{2} h}{\partial y^{2}}+\frac{\partial^{2} h}{\partial z^{2}}=Q_{v}
$$

\section{Hydrogeological modeling and dewatering programs}

In the last 10 years, application of hydrogeological modeling in mining has become an indispensable tool to optimize mineral resource exploration. Mining companies have been incorporating mine dewatering based on groundwater flow numerical modeling.

Domination Diamond (2014) presents the importance of hydrogeological modeling within mine planning. The geometry of Jay Diamond mine (Northwest Territory, Canada) was modified due to the challenges of dewatering. Simulations in that mine showed pumping evolution from $500 \mathrm{~m}^{3} / \mathrm{h}$ to $900 \mathrm{~m}^{3} / \mathrm{h}$ over 10 years and the demand to promote mine drawdown six months before starting mining activities (pre-dewatering). Pre-dewatering approach, which is widely used in mining, means to anticipate drawdown with a few pumping wells and consequently to reduce interference with mine operations. Timing issues for well installation programs and other drainage systems are important for mining planning.

Victor Mine (Ontario, Canada) is another example of mining activity that required numerical modeling before go through dewatering, according Atkinson et. al. (2014). The geographical isolation of this mine, associated with a rigorous winter, makes logistics for its operation quite complex. Its development increases operational costs, since analysis of technical and financial feasibility must predict dewatering costs, which, if not well dimensioned, can affect the economic sustainability of the mine. In addition to the challenges related to the high pumping rates and well location, there is a small river in the mine region, whose defluence will be impacted by the enlargement of the cone of depression (Figure 17). 

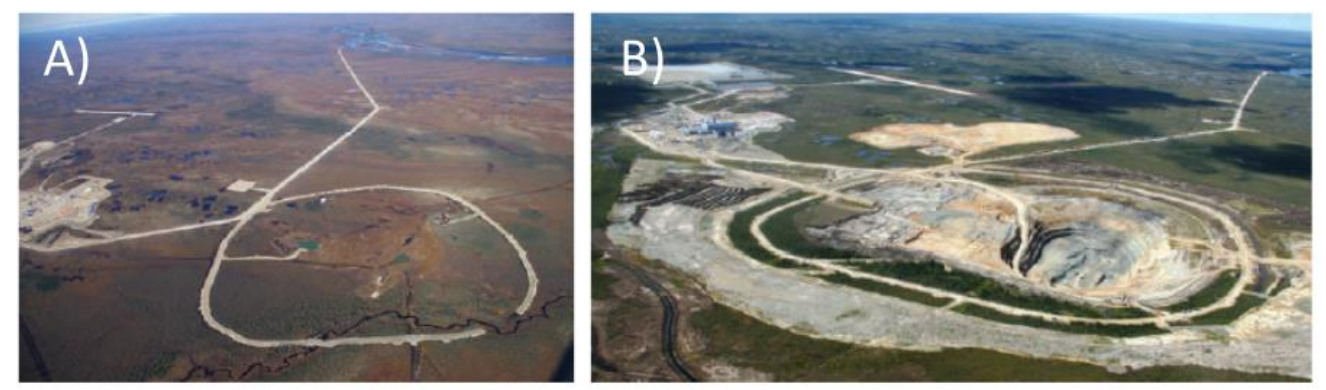

Figure 17 - (A) Victor Mine area before open pit and Attawapiskat River; (B) Victor Mine deposit two years after the start of its operation (BEALE \& READ, 2014).

Diavik mine (Nortwest Territories, Canada), which exploits diamonds in kimberlitic pipes (Figure 18), has a complex operational system to promote dewatering. Numerical model described by Beale and Read (2014) simulated fracturing system zones and verified the operation of a dewatering program to be developed for some zones.

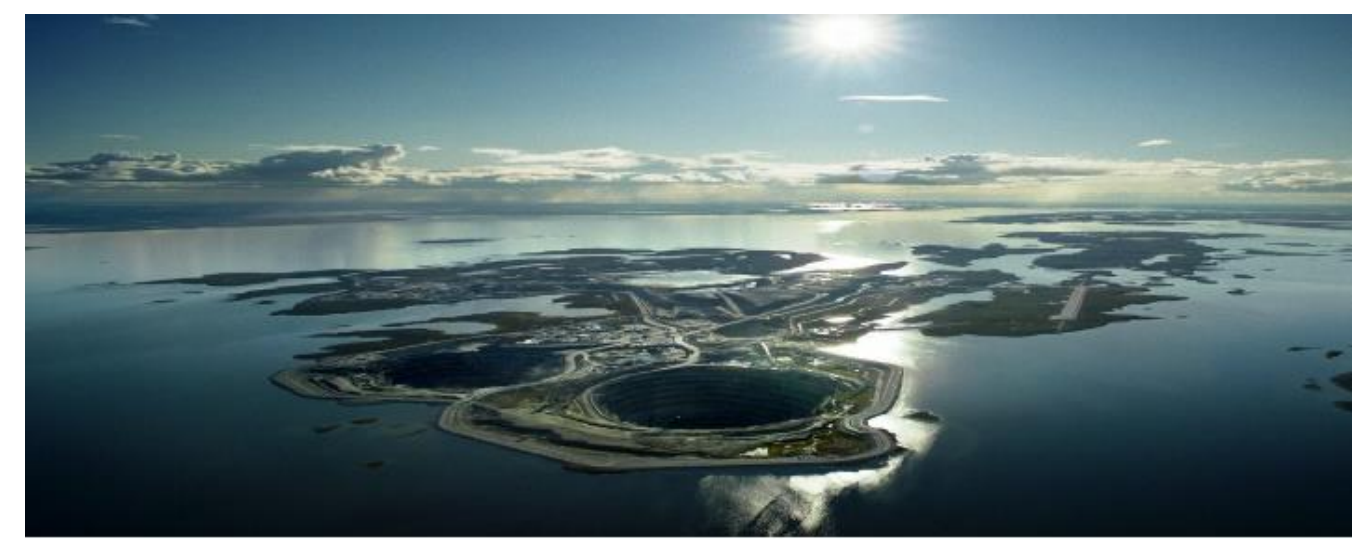

Figure 18- Diavik mine locate in Lac Grass region (DOMINATION DIAMOND, 2014).

In Brazil, hydrogeological modeling in mining is used in large-scale mines, to support dewatering plans. Modeling techniques can be applied for both open pit and underground mines. Vazante Mine (Minas Gerais, Brazil) is an example of underground zinc mine, which requires a pumping rate of $11,000 \mathrm{~m}^{3} / \mathrm{h}$ (GUIGUER et al., 2013).

\section{Pit Slope Stability}

Water level drawndown and rocky masses depressurization reduce costs of geotechnical applications to contain pit slopes. In addition to improving slopes geometry, a dewatering plan promotes the development of slope stability (without water).

Read and Stacey (2009) figured out that geotechnical studies associated with hydrogeological modeling could reduce costs related to geotechnical accidents. Besides management of geotechnical risks, hydrogeological modeling allows the evaluation of saturated or non-saturated geomechanical parameters, as well as regions in pit with higher transmissivity. Anticipating slope depressurization allowed increase of general slopes angle, making access to 
mineralization zones easier. Within a long-term scenario, increase of two degrees in slope angle reduced costs by approximately US $\$ 225$ millions.

Beale and Read (2014) reveal, according to financial analysis carried out by Schlumberger company for diamond mines in Canada, that hydrogeological modeling applied focusing on mine slope stability generates an economy directly proportional to slope depressurization actions.

Geotechnical engineering uses 3D groundwater flow models to evaluate groundwater hydraulic behavior on slopes faces. Liu et al. (2012) developed a hydrogeological model for the copper mine of Chuquicamata (Chile) in order to simulate pore-pressure imposed by groundwater flow on slopes face. Simulation results allowed determining regions of greater movement caused by zones of relaxation.

Carneiro (2013) studied slopes stability projected in a region close to the Piracicaba River in Alegria Mine. Stability analyzes showed that pore-pressure caused by groundwater flow causes negative effects on slope stabilization (Factor of Safety $<1$ ), mainly at the intersection between Alegria Norte and Alegria Sul. Water pressure acting over discontinuities and porous rock masses reduces effective tension, with consequent decline of rock shear strength. In this situation, dewatering becomes mandatory for mining operational safety conditions.

\section{Environmental risks associated to dewatering}

Impacts evaluation regarding superficial water availability, after an extensive dewatering program, is necessary through hydrogeological numerical modeling. An important aspect of water balance modeling is to quantify the contribution of several sources in recharge and discharge zones.

Bertachini and Almeida (2002) described the importance and application of numerical groundwater flow model in mining to plan the number of pumping wells and extraction flow rates. Futhermore the numerical model results can indicate the environmental impacts with the cone of depression evolution along the spring, streams and rivers. Groundwater overexploitation aiming dewatering can generate impacts on surface water availability, and it is possible to plan in advance engineering solutions for the restitution of groundwater in surface water bodies.

\section{Dewatering techniques}

The main practices to access ore reserves below water table involve installation of a set of pumping wells to achieve mine dewatering and cut-off walls to act as barriers for groundwater flow and therefore to protect superficial water from depletion. Generally, these structures are preceded by engineering studies and require a technical-economic viability analysis to carry out implementation, on account of high financial costs.

Powers et al. (2007) propose application of several methods besides cut-off walls for the control of groundwater flow in mining, which can be simulated in hydrogeological numerical 
models, such as deep horizontal wells (DHW), gallery drainage, slurry walls and even freeze walls, the last one a temporary intervention.

\subsection{Pumping Wells}

Pumping wells are catchment structures intended for groundwater exploitation. They are composed by tubes, filters, pump, electrical cable and electrical panel (Figure 19).

Pumping wells can be classified according to their use or purpose, size and type of aquifer. In addition to the functionality of supplying water to a single residence or large cities, the wells are widely used in mining to promote drawdown of water level.

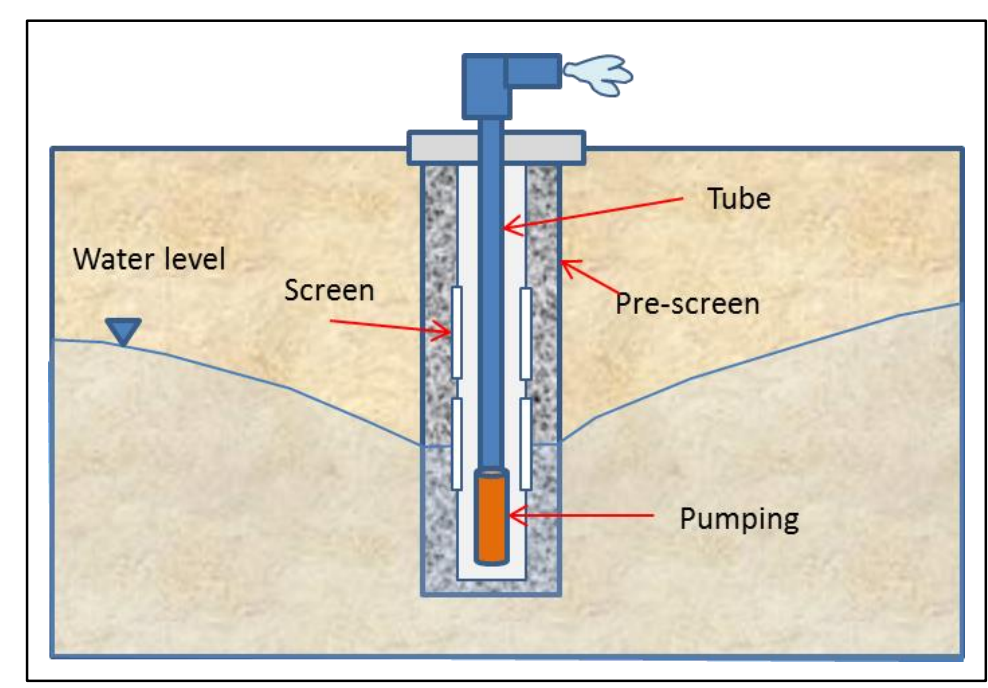

Figure 19 - Pumping well profile with the all equipaments

Pumping wells have been used in iron mines of Quadrilátero Ferrífero (Minas Gerais State, Brazil) as an alternative to make mineral reserve feasible since the beginning of 1980s with Águas Claras Mine in Belo Horizonte and Conceição Mine in Itabira (BERTACHINI, 1994).

\subsection{Cut-off walls}

A cut-off wall is a practice used in mineral sector to reduce the amount of pumping wells. This structure is a tabular barrier that decreases permeability of porous medium in vertical or horizontal direction (Figure 20). Most of cut-off walls can reach a hydraulic conductivity of less than $10^{-8} \mathrm{~m} / \mathrm{s}$ using some polymers, bentonite and cement (POWERS et al., 2007). Timms et al. (2013) indicated that there are cut-off walls with depths ranging from 6 to $50 \mathrm{~m}$ and the thickness from 0.8 to $3 \mathrm{~m}$.

Although it is a technique with high investment costs, cut-off walls can save costs related to installation/operation of large equipment, pumping wells and electrical systems inside the pit. Reducing pumping wells can bring financial gains, as savings with energy expenses. This method can be applied to decrease the amplitude of cone depressions in regions close to rivers or lakes. 
Timms et al. (2013) described best practices of applying cut-off walls in mining activities. They outlined the constructive steps of cut-of walls and performed permeability tests and numerical hydrogeological modeling. The simulation results showed that cut-walls application decrease slope seepage.

Hunter Valley coal mine has a cut-off wall 1,200 m long and $15 \mathrm{~m}$ thick to control impacts on Hunter River as well to reduce groundwater flow into the mine (DARACON, 2010). Approximately $300,000 \mathrm{~m}^{3}$ of bentonite and polimers was used. As a result, cut-off wall in this site can decrease the seepage slope and keep the Hunter River flow-rate.

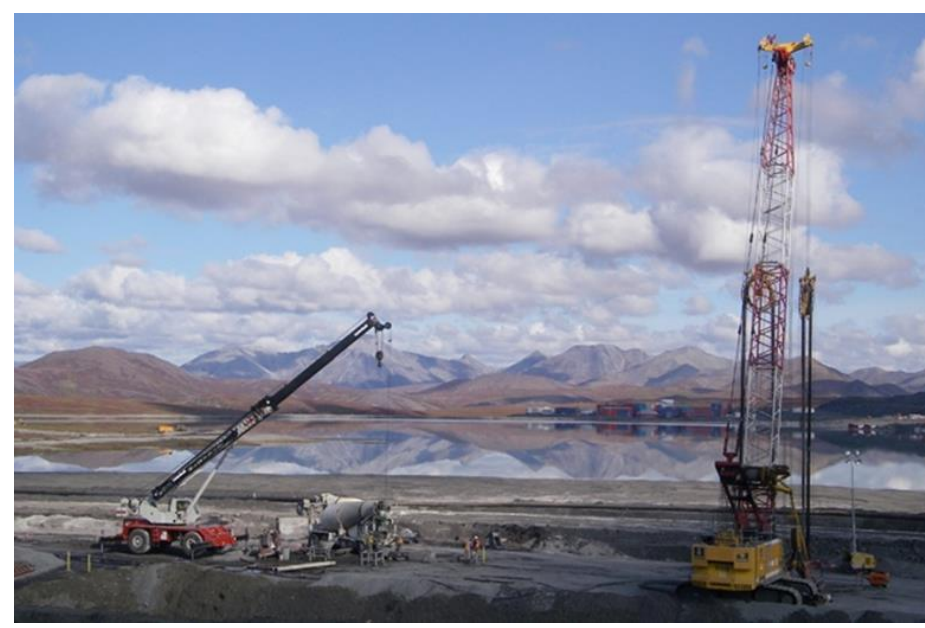

Figure 20 - Red fog cut-off wall close to lake (GOLDER, 2016).

In Diavik Mine a cut-of-wall 3,800 m long was built to control groundwater seepage and surface water run-off inside the pit. Bentonite, cement and crushed granite were employed in this barrier.

\section{Hypothetical simulation case}

To support management decisions regarding groundwater explotation in a large open pit, a hyphothetical simulation was done to simulate cut-off wall application close a river to compriese its capacity to reduce seepage slope and the river leakage to aquifer. The simulated case was based on a hypothetical unconfined aquifer, homogeneous and isotropic type in transient state. It was assumed that a $25 \mathrm{~m}$ drawdown along one year would be necessary to maximize ore extraction. This modeling was carried out using Visual Modflow software package tools (GUIGER \& THOMAS, 1998)

Hypothetical model's domain consisted of a box-shape with 2,000 $\mathrm{m}$ long in both $\mathrm{X}$ and $\mathrm{Y}$ directions and 4 layers, each of them 25 m thick, resulting in a grid of 40 columns per 40 rows per layer and 6400 grids all model. Top and bottom model elevations were $100 \mathrm{~m}$ and $0 \mathrm{~m}$, respectively. Boundary conditions were no-flow for the bottom and recharge, river and evapotranspiration for the top. On the lateral sides of this model-box, no-flow boundaries with 
inactive cells were assigned. First layer was later discretized to simulate a $12.5 \mathrm{~m}$ long cut-off wall. Recharge value was set as $200 \mathrm{~mm} /$ year for all area as it was for evapotranspiration to control hydraulic head with $5 \mathrm{~m}$ of extinction depth.

Four pumping wells were placed in cells $7 / 17,15 / 17,23 / 17$ and $31 / 17$ (i.e., cell 31/17 means Line 31, Column 17), in continuous operation at extraction rates of $3,000 \mathrm{~m}^{3} /$ day each one. Two observed wells in cells 18/22 and 18/34 were inserted in simulated model to evaluate the drawdown evolution. Model's dimensions and input data are given in Table 5. Figure 21 shows model's domain and locations of the river, pumping wells and cut-off wall. Cut-off walls hydraulic conductivity was fixed in $10^{-8} \mathrm{~m} / \mathrm{s}$ and its thickness varied between 1 and $2 \mathrm{~m}$. Cut-off walls were simulated for the depths $12.5 \mathrm{~m}, 25 \mathrm{~m}, 50 \mathrm{~m}, 75 \mathrm{~m}$ and $100 \mathrm{~m}$, the last one considering all aquifer thickness. Additionally, cut-off thickess varing from $1 \mathrm{~m}$ to $2 \mathrm{~m}$ were simulated in $50 \mathrm{~m}$ and $75 \mathrm{~m}$ depths, as a result of application depth used in large open pit.

Table 5 - General simulation input data of cut-off walls models.

\begin{tabular}{|l|l|}
\hline \multicolumn{1}{|c|}{ Parameters } & \multicolumn{1}{c|}{ Value } \\
\hline Hydraulic Conductivity (K) & $1 \mathrm{~m} /$ day \\
\hline Specific Yield (Sy) & 0.04 \\
\hline Specific Storage (Ss) & $1 \times 10^{-5} / \mathrm{m}$ \\
\hline Aquifer Top & $100 \mathrm{~m}$ \\
\hline Aquifer Bottom & $0 \mathrm{~m}$ \\
\hline Horizontal Grid & $40 \mathrm{~m} \times 40 \mathrm{~m}$ \\
\hline Initial Head & $100 \mathrm{~m}$ \\
\hline Total Pumping Rate & $12,000 \mathrm{~m}^{3} /$ day \\
\hline Simulated time & 360 days \\
\hline
\end{tabular}
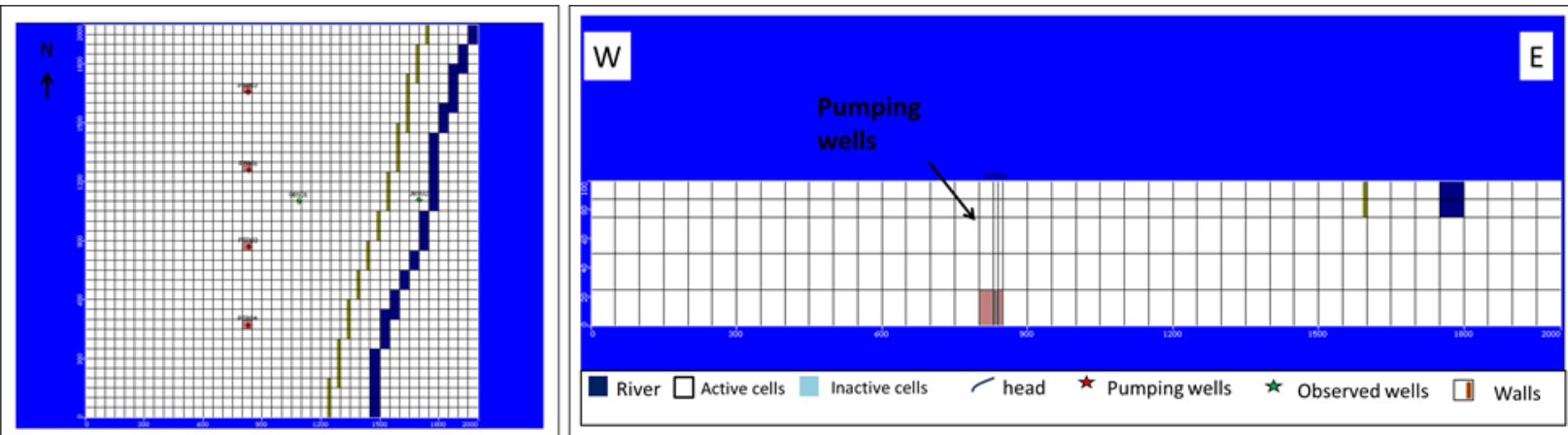

Figure 21 - Horizontal and cross section (row 15) of numerical model with the domain, boundary conditionals, pumping wells and cut-off walls.

\section{Results and Discussion}

Simulation results indicated that cut-off walls with relative depth and thickness decrease river capacity to supply water to aquifer, after evolution of extensive cones of depression.

In the first stage of simulation, the box-model without cut-off wall was tested as reference to verify river capacity in keeping flow rate stable along days of groundwater exploitation. In the 
first 150 days, extension of cone of depression decreased only the base-flow, but river still remained effluent. After 150 days, river started to provide water to aquifer (Table 6 and Figure 22).

Figure 23 presents plan view and W-E cross sections of the groundwater flow-directions considering continuous pumping until 150 days simulation. Observation of hydraulic heads allows to confirm dewatering evolution for the time steps 30, 90 and 150 days. Flow direction in east part of the model in the first 30 days shows aquifer giving water to river. In 90 days, extension of the cone depression still does not intercept the river. From 150 days, cone of depression finally intercepts the river.

In the second stage of simulation, cut-off walls were placed in the box-model constructed in first stage, for distinct barrier design scenarios: thickness, 1 or $2 \mathrm{~m}$ and depth ranging between 12.5 and $100 \mathrm{~m}$. Despite complexity to build a cut-off wall with depth greater than $70 \mathrm{~m}$ in the real world, the numerical model simulated the cut-off wall behavior for the total aquifer thickness. To evaluate cut-off wall efficiency, results were compared with simulation without this structure. Model responses in terms of hydraulic head in two observation wells (18/22 and 18/35) were observed when cut-off walls depth and thickness were varied (Figure 18).

Cut-off walls with 50 and $75 \mathrm{~m}$ depth reduced $25 \%$ on average the extension of cone of depression, so decreasing river leakage towards aquifer (Table 6). Piezometer (close to the river and protect by cut-off walls) presented the smaller hydraulic head decrease. In contrast, the observation well not protected by cut-off wall was affected by drawdown.

According to figure 24, cut-off walls with $12.5 \mathrm{~m}$ and $25 \mathrm{~m}$ depth and $1 \mathrm{~m}$ thick show consistently similar results to simulation without wall. Since pumping well screens are below the bottom of wall, this structure is not capable to significantly prevent water flow from river to aquifer/wells. In this case, river leakage to aquifer started in 150 days of pumping. Cut-off walls with $50 \mathrm{~m}$ and $75 \mathrm{~m}$ depth and $1 \mathrm{~m}$ thick reduce the risk of cone of depression to intercept the river. After wall, box-models showed that application of cut-off walls is more efficient close to pumping wells, since the barriers are deep enough to block pumping well catchment area, in that way avoiding water from flowing from river to aquifer. Cut-off walls installed along all aquifer thickness $(100 \mathrm{~m})$ attested structure ability to control groundwater flow net.

Besides depth analysis, simulations were also conducted to test cut-off wall thickness for 1 and $2 \mathrm{~m}$. Results indicated that this parameter do not influence river leakage. 
Table 6 - General simulation data of cut-off walls

\begin{tabular}{|c|c|c|c|c|c|c|c|c|}
\hline \multicolumn{9}{|c|}{ Flow rate from aquifer to river } \\
\hline \multicolumn{7}{|c|}{$1 \mathrm{~m}$ thickness } & \multicolumn{2}{|c|}{$2 m$ thickness } \\
\hline Time [day] & WITHOUT WALL & WALL $12.5 \mathrm{~m}$ & WALL 25m & WALL 50m & WALL $75 \mathrm{~m}$ & WALL 100m & WALL 50m & WALL 75m \\
\hline 30 & 2460.2 & 2457.4 & 2453.2 & 2441.7 & 2422.6 & 2386.1 & 2440.3 & 2419.6 \\
\hline 60 & 1857.9 & 1856.5 & 1854.1 & 1848.3 & 1835.9 & 1808.6 & 1847.2 & 1833.3 \\
\hline 90 & 1305.5 & 1307 & 1309.6 & 1319.1 & 1330.7 & 1353.6 & 1319 & 1330.9 \\
\hline 120 & 783.78 & 787.66 & 795.35 & 820.65 & 859.19 & 944.93 & 821.76 & 862.59 \\
\hline 150 & 300.75 & 305.89 & 317.54 & 356.72 & 420.2 & 568.64 & 358.84 & 426.51 \\
\hline 180 & 11.734 & 12.763 & 15.221 & 26.995 & 65.686 & 222.19 & 28.108 & 66.56 \\
\hline 240 & 0 & 0 & 0 & 0 & 0 & 0 & 0 & 0 \\
\hline 300 & 0 & 0 & 0 & 0 & 0 & 0 & 0 & 0 \\
\hline 360 & 0 & 0 & 0 & 0 & 0 & 0 & 0 & 0 \\
\hline \multicolumn{9}{|c|}{ Flow rate from river to aquifer } \\
\hline \multicolumn{7}{|c|}{$1 \mathrm{~m}$ thickness } & \multicolumn{2}{|c|}{$2 m$ thickness } \\
\hline Time [day] & WITHOUT WALL & WALL $12.5 \mathrm{~m}$ & WALL $25 \mathrm{~m}$ & WALL 50m & WALL 75m & WALL 100m & WALL 50m & WALL 75m \\
\hline 30 & 0 & 0 & 0 & 0 & 0 & $\begin{array}{r}0 \\
\end{array}$ & 0 & 0 \\
\hline 60 & 0 & 0 & 0 & 0 & 0 & 0 & 0 & 0 \\
\hline 90 & 0 & 0 & 0 & 0 & 0 & 0 & 0 & 0 \\
\hline 120 & 0 & 0 & 0 & 0 & 0 & 0 & 0 & 0 \\
\hline 150 & 0.75461 & 0.58188 & 0.17213 & 0 & 0 & 0 & 0 & 0 \\
\hline 180 & 155.36 & 150.47 & 137.3 & 97.733 & 51.075 & 0.80617 & 95.888 & 43.172 \\
\hline 240 & 919.55 & 913.94 & 892.78 & 822.93 & 702.77 & 395.08 & 818.88 & 690.05 \\
\hline 300 & 1577.6 & 1573.8 & 1548.8 & 1465.7 & 1319.2 & 925.64 & 1460.9 & 1303.4 \\
\hline 360 & 2143.6 & 2141.9 & 2115 & 2022 & 1853.4 & 1388.5 & 2016.7 & 1835.9 \\
\hline
\end{tabular}

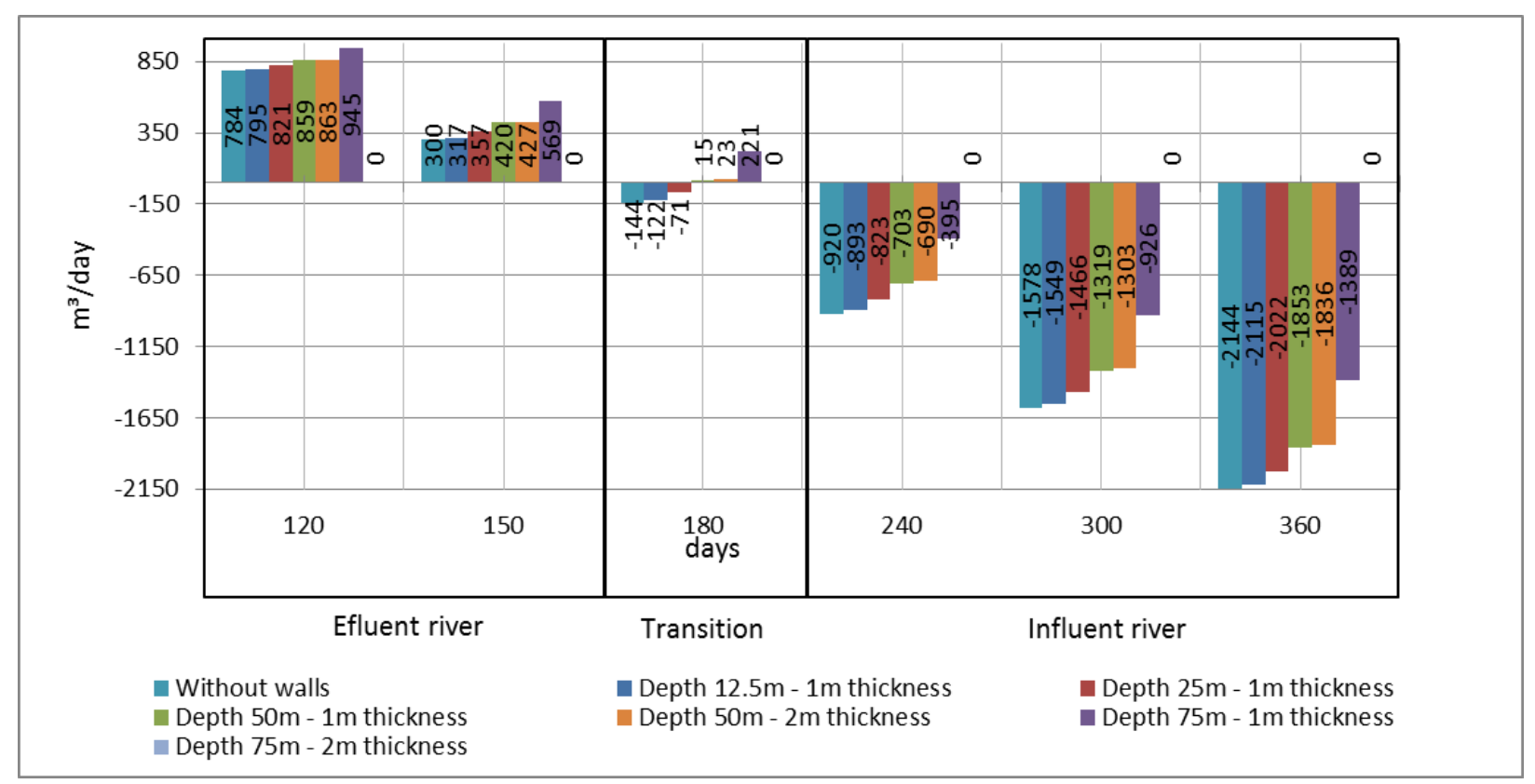

Figure 22- Cut-off wall water results simulation. Lower values indicate that cut-off wall prevented water outflow compared to a scenario without the barrier. 


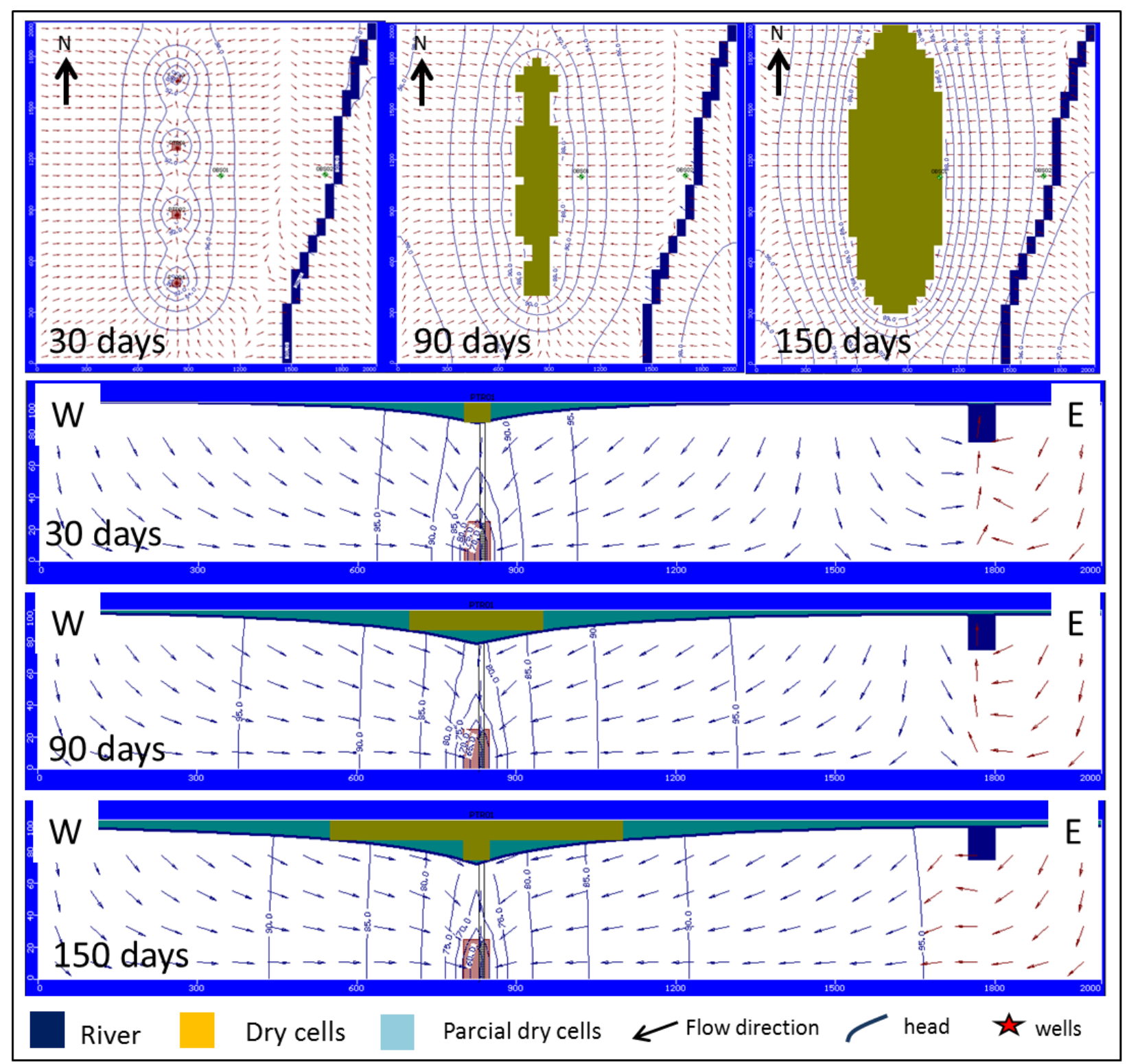

Figure 23 - Hypothetical numerical model without cut-off walls with a horizontal view (layer 1) and vertical section (row 15). Cone of depression intercepts the riverbed after 150 days. 


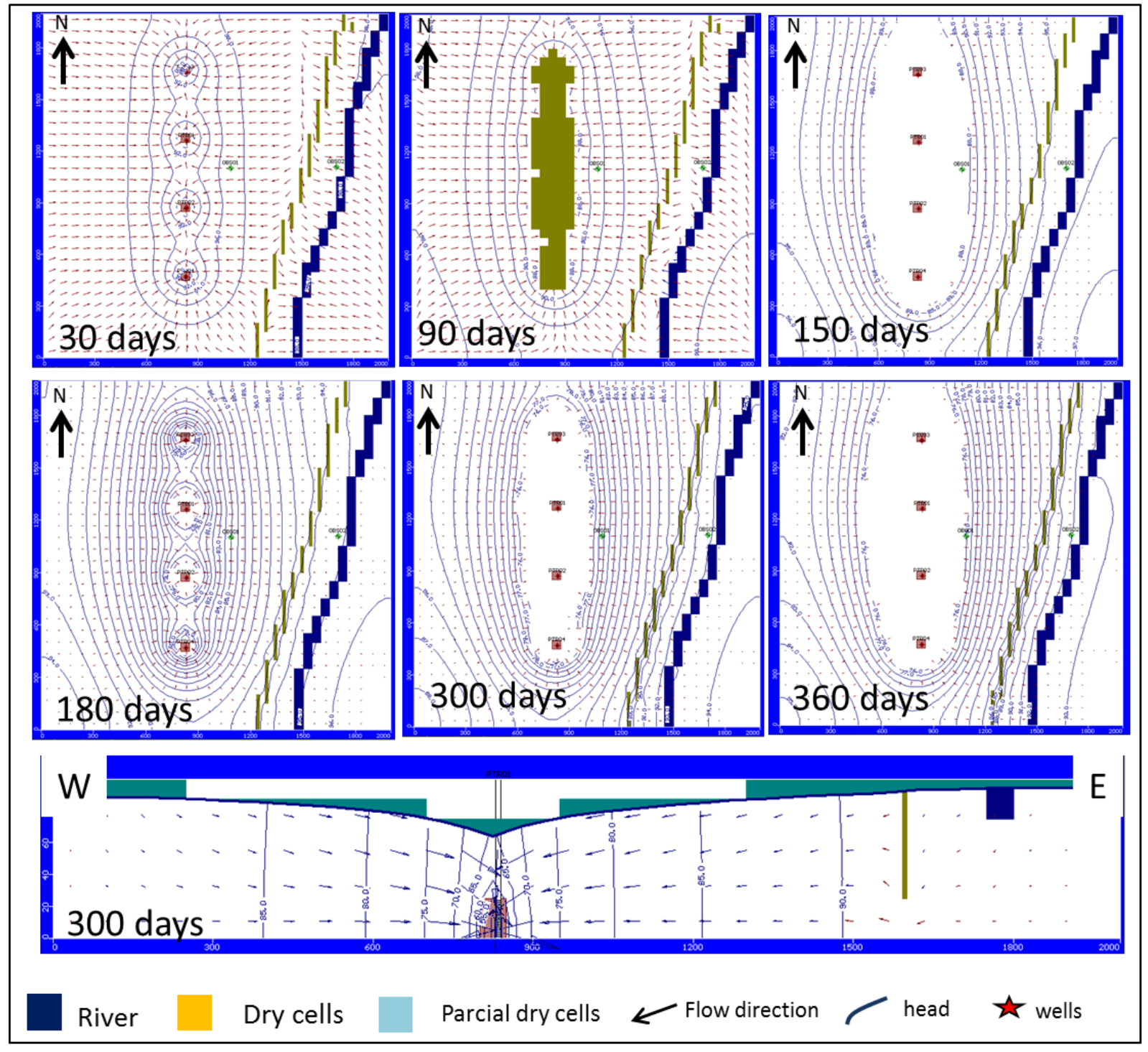

Figure 24 - Hyphotetical numerical model with cut-off walls. Extension reduction of the cone of depression along river.

\section{Conclusions}

Numerical hydrogeological model is a robust tool to evaluate dewatering challenges in mine exploration. The effort level required at each stage of project development can be shown by each component of hydrogeological model. IGroundwater and surface waters interaction should be taken into account in all stages of mine planning, especially during mine operation.

Groundwater can have a negative effect on slope stability and consequently on ore reserve access. To reach total ore reserve, many pits must to be excavated deeper below the water table leading to an increase the number of pumping wells and more mine operation interferences. As open pit mines scale gets larger and regulatory constraints in most countries get tighter, the water evaluation and management become increasingly important for all mine operators and corporate mining. As result, application of numerical models to plan number of pumping wells or implementation of cut-off walls must be incorporated in mine planning process. 
Hypothetical hydrogeological models was used in this study to demonstrate cut-off wall application in mitigating environmental impacts and reducing extension of cone of depression caused by groundwater exploitation over rivers and streams. According to the results, cut-off walls 50 and $70 \mathrm{~m}$ deep reduced the impact in river flow rate by $25 \%$. In addition, cut-off walls increased water drawdown inside the pit. However, in order to keep the river flowing in its natural state, it is necessary to restore groundwater.

\section{Acknowledgements}

To Samarco Mineração SA for financial support. A special thanks goes for Diego Nunes for technical discussions.

\section{References}

Atkinson, L. C., Keeping, P. G., Wright, J.C., 2009, The economic challenges of dewatering at the Victor Diamond Mine in Northern Ontario, Canada. Abstracts of the International mine Water Conference. Pretoria, South Africa.

Beale, G., and Read, J., 2014: Guidelines for Evaluating Water in Pit Slope Stability, CSIRO Publishing, Australia and New Zealand

Bertachini, A.C., 1994, Hidrogeologia e desaguamento da Mina de Águas claras. VIII Congresso Brasileiro de águas subterrâneas. ABAS Recife.

Bertachini, A.C., Almeida, D.C., 2002, O rebaixamento do nível d'água em mineração e obras civis, In: Simpósio de Hidrogeologia do Sudeste. 19-28 p.

Carneiro S.R.C., 2013: Caracterização mecânica e hidrogeológica dos maciços das cavas de Alegria Centro e Sul, Samarco Mineração S.A. Dissertação de Mestrado, Departamento de Engenharia Civil, Universidade Federal de Viçosa, Brasil.

Daracon, 2010. Carrington barrier wall [online]. Disponível em: <http://www.daracon.com.au/What-WeHave-Achieved/Project-Profi les/Carrington-Barrier-Wall.aspx> [Visualizado em: 10/05/2013].

Domination Diamond, 2014, Hydrogeological model pre-mining, during mining and closure plan.Relatório interno. Disponível em: http://reviewboard.ca/upload/project_document/EA13141_S_08A_Hydrogeological_Model.PDF. Acesso em: 05/05/2016.

Golder (Golder Associates Ltd.). 2004. Diavik Hydrogeologic Numerical Model December 2004 ReCalibration. Submitted to Diavik Diamond Mines Inc.

Guiguer, N., Thomas, F. Visual MODFLOW. Waterloo Hydrogeologic, Inc., Waterloo, Canada. 1998

Guiguer, N., Todd, K., Brent, M., Medeiros, R., 2013. Estudo de caracterização dadinâmica de fluxos subterrâneos a partir da injeção de técnicas baseadas na utilização de traçadores corantes. Relatório interno da DHI \& GeoHydros LLC elaborado para a Votorantim Metais Mina de Zinco de Vazante, Vazante, MG.

Read, J., Sacey, P., 2009. Guidelines for Open Pit Slope Design. CISRO Publishing, Melbourne. 
Powers, J.P., Corwin, A.B., Schmall, P.C., Kaeck, W.E., Herridge, C.J., Morris, M.D., 2007: Construction Dewatering and Groundwater Control - New Methods and Aplications. 3를 Edição. USA.

Timms, W., Liu, H. Laurence, D. 2013. Design of Low Permeability Barriers to Limit Subsurface Mine Water Seepage. In Water in Mining Conference. Brisbane. Australia. 


\section{CHAPTER 5 - GEOLOGIC AND TYPOLOGICAL 3D MODEL FOR ALEGRIA MINE, EAST PART OF QUADRILÁTERO FERRÍFERO, MINAS GERAIS, BRAZIL}

João Paulo Chiste-Costa, Alexandra Vieira Suhogusoff, Luiz Carlos Ferrari

\section{Abstract}

One of the most difficult aspects of modelling in poly-deformed areas, mainly in itabirites, is to establish the continuity of type-itabirite body in the space. Although, the main criteria to model different ore bodies are related to the mineralogical composition of the itabirite, which are the chemical and granulometrical variables that can take into account in the modeling. The geological process as the tectonism, metamorphism and weathering resulted in different types of itabirites in Alegria Mine. It should be noted that minerals are very heterogeneous, with varying proportions of amphiboles, magnetite, martite, specularite and goethite. The predominant mineral is the varietal species, which gives name to the type of ore. Using data from geological mapping, topographic surfaces, descriptions of boreholes and petrographic studies in polished sections, the 3D geological typological model of Alegria Mine can be used in hydrogeological, geomechanical and geometalurgical models. 3D geological typological model can show the main mineralization directions, which are important parameters to quantify the mineral resource and the ore reserve.

\section{Introduction}

In iron ore mining companies, new trends in the elaboration of geological and typological models of the mineral resource include the identification and quantification of mineralogical, chemical and granulometric parameters, which govern the quality of iron ore specification to steelmaking processes. The construction of 3D geological models of different rock types and complex structures through computer graphics represents an important tool for interpretation of geological data and mine planning activities in Samarco Mineração SA, a Brazilian iron ore mining company. Since 1977 Samarco Mineração SA has explored and processed itabiritic ore in part of Alegria Mine, close to Vale's iron ore operation. The iron ore concentrate produced from Alegria Mine in Samarco's facilities are pumped in pipelines (almost $400 \mathrm{Km}$ ) to pelletizing plants in Espírito Santo State (ROCHA, 2008).

There are many benefits to construction of geological models since they are results of the integration of knowledge, as well as combination of varied data. The geological model applicability allows reserving and estimation of ore reserves, refining slope design and supporting the conceptual hydrogeological model. 


\section{Study Area}

Alegria Mine is located on the east part of Quadrilátero Ferrífero in the Mariana and Ouro Preto municipalities, central part of Minas Gerais State, Brazil. The distance from Alegria Mine to Belo Horizonte is approximately $150 \mathrm{~km}$ following the BR-356 Road. The nearest towns are Mariana $(32 \mathrm{~km})$ and Santa Barbara $(40 \mathrm{~km})$. Close to Mariana, to access the study area is preferably via the MG 129 Road, 17 km north of the district of Antônio Pereira (Figure 19).

Three main sectors are distributed along the Alegria Mine area, under Samarco's concession. While the south-central portion of the deposit is operated exclusively by Samarco SA, the northern part is operated jointly by Samarco (West) and Vale (East). Operational pits are positioned along the ore body, with a S-N strike direction, turning to NE in the extreme north of the mine, following a syncline fold (Alegria Syncline). The N-S distance between the two extreme points of the mine is about $6.5 \mathrm{Km}$, represented by Alegria North, Alegria Center and Alegria South.

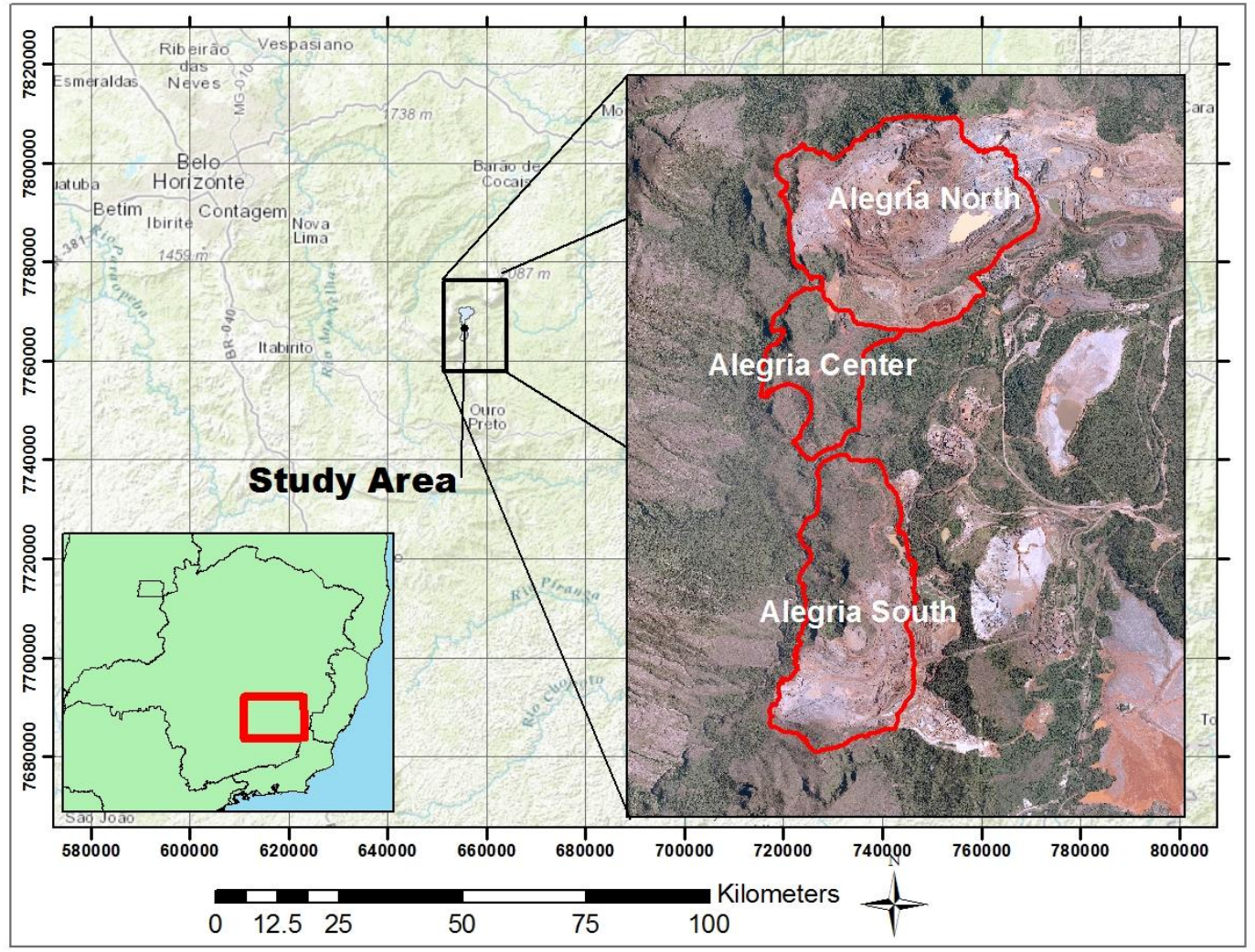

Figure 25 - Map location of study area

\section{Geological Context}

Alegria Mine is located on the eastern portion of the Quadrilátero Ferrífero, in a region of great magnitude of deformation and average metamorphic temperatures (about $512^{\circ} \mathrm{C}$ ), compatible with the transition conditions between the greenschist and amphibolite facies (HOEFS 
et al., 1982). The geological units in the Alegria Mine are represented by Moeda, Batatal, Cauê formations and Piracicaba and Sabará groups (ALKMIN, 1988). These geological units belong to Minas Supergroup that is overwhelmed by Itacolomi Group quartzites in an angular contact.

In Alegria Mine stratigraphic sequence occurs mainly metamorphic banded iron formation (from 30 to $64 \% \mathrm{Fe}$ ), also known as itabirite belongs to the Cauê Formation, the most important geological unit to mineral economic setor in Quadrilátero Ferrífero. The itabirites may be friable, powdery and compact (VERISSIMO, 1999). In general, laterite crust and compact hematite are not representative in terms of volume in Alegria Mine, being mappable only in scale of detail. In contrast, itabirites are marked by banded structure and, according to the most frequent mineral, can be distinguished in specularitic, amphibolytic, martitic, goethittic and magnetithic itabirite (ROCHA, 2008).

The basal units are Moeda and Batatal formations, composite by lenticular enclaves or polydeformed tabular bodies of quartzites and phyllites. Quartzites from Moeda Formation are recognized in the eastern portion of Alegria Mine, which support a high mountain range with altitudes above $1800 \mathrm{~m}$. Phyllites appear surrounding Cauê Formation and can be recognized by the gray-silvery coloration to orange-yellow and they are composed basically of sericite and variable quantities of quartz, arranged in diffuse bands. Batatal Formation phyllites found at the base of Cauê Formation. Phyllites from Formation Cercadinho and Group Itacolomi overlies the metamorphic banded iron formation by discontinue contact.

Intrusive metabasites dikes occur in the form of discontinuous bands and lenses of variable thickness, intrusive and discordant of the other rocks. These dykes are totally weathered, constituting of clay material of ocher color. In some parts of the Alegria Mine dikes of metabasites present partially preserved structure, being possible the identification of plagioclase and altered amphiboles. The penetrative foliation indicates that dikes were later affected by tectonometamorphic processes, making intrusive bodies discontinuous and structurally compartmentalized.

\section{Materials and Methods}

Different types of itabirites were characterized by 1,623 drillholes from the geological research campaigns carried out between 2005 and 2012 (Table 8). Typological classification focused on the mineralogical assembly, described in more detail by several researchers (VERÍSSIMO, 1999; ROCHA, 2008; SAMARCO, 2012).

Subsurface data comes from diamond rotate drilling. In order to profile the boreholes and measure drill deviations were used two different methods of Maxibor (until 2007) and Deviflex. 


\section{Table 7 - Drillholes database from 2005 to 2012}

\begin{tabular}{|c|c|c|}
\hline Resource Area & Drillholes & Total Drilled $(\mathrm{m})$ \\
\hline Alegria North & 903 & 11,3815 \\
\hline Alegria South & 626 & 85,411 \\
\hline Alegria Center & 94 & 17,660 \\
\hline Total & 1,623 & 216,886 \\
\hline
\end{tabular}

First, geological contacts were defined, such as laterite, itabirites, phylites/schists, quartzites and intrusive rocks. Then, itabirite lithology was subdivided first into different mineralogical types which take account different mineralogical associations. After that, various mineralogical itabirites samples were subdivided into eight meters long regarding the mining benches dimensions. Then, the samples were homogenized and quartered (pile) to generate aliquots to be analyzed and tested.

Mineralogical analysis is performed using reflected light microscopy. Mineralogical phases (specular hematite, porous hematite, goethite, magnetite, liberated quartz, non-liberated quartz and others) are determined by weight and volume, using polished sections. A minimal of 500 particles is counted. All databases were uploading to GEMS 6.7 software (GEOVIA, 2015).

The cartographic base used to represent the surface of the deposit was the topographic plant of 1999 to encompass all the exploration boreholes made in the mineral research campaigns. After the input of all the information, a lithostructural model is generated, allowing the spatial visualization of the deposit, the drilling holes and the mineralogical, chemical and granulometric information of the samples.

\section{Results and Discussion}

\subsection{Iron ore characterization}

Mineralogical and textural transformations of Alegria Mine ores are strongly linked to the temperature and pressure conditions that followed the tectonic processes and to the processes of recent weathering. Thus the result is a varied range of iron ores types and associated rocks.

The mineralogical compositions suggest an origin of facies oxide for the iron formations and facies silicate to oxide silicate containing carbonate layers responsible for generation of the amphibolitic itabirite (VERÍSSIMO, 1999; ROCHA, 2008; and SAMARCO, 2012).

Magnetite crystals are found in forming aggregates with other iron ore minerals interspersed with layers of quartz. Usually, crystals are hypidiomorphic, ranging from 0.05 to 5 $\mathrm{mm}$, and presenting features typical of the martitization process (Figure 26). In deformation zones, magnetite can appears forming a structure of milonitic S-C type or between specularite. 


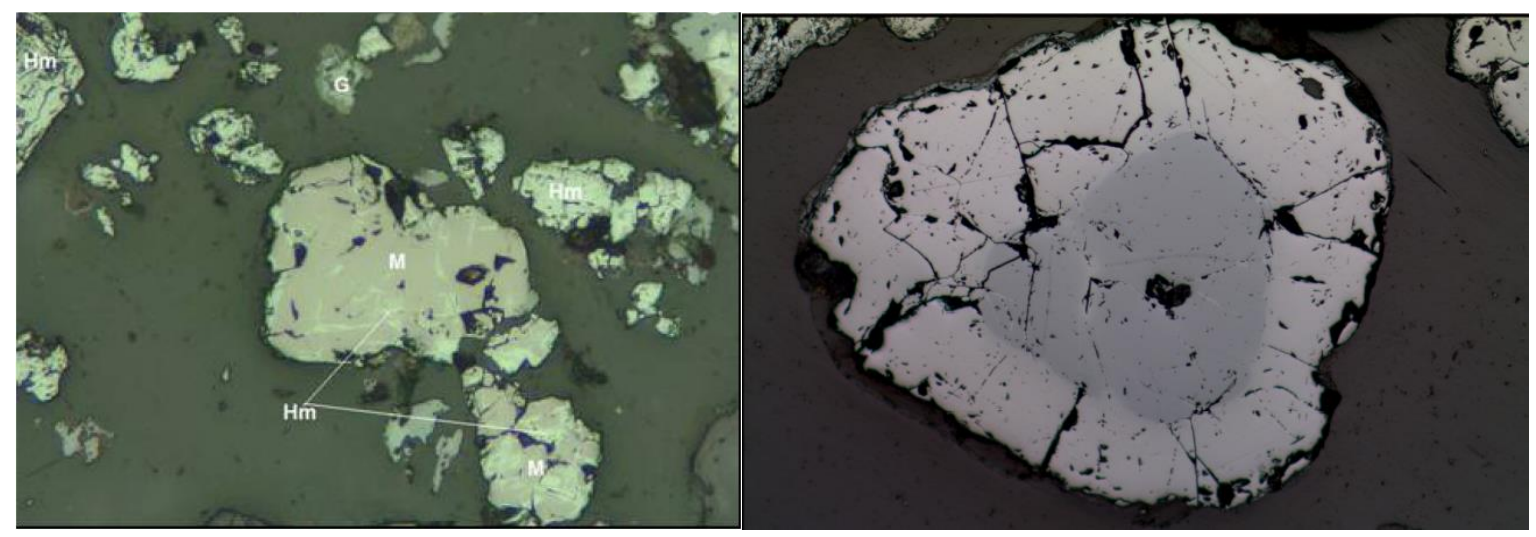

Figure 26 - Magnetite (MA), Martite (HM) e Goethite (Gt) - under reflect microscope x300 (Samarco, 2012).

Hematite occurs in several stages generation with different forms, from thin to thick plates, micaceous and foliate, specular and concretions (Figurre 27), classifying this ore type as specular hematite $(\mathrm{HE})$. However, this type of mineral can appear with terrestrial habit, denominated porous hematite or martite (HM), formed after the magnetite alteration (Figure 28). Hematite formation from magnetite may happen through actuation of metamorphic processes or through supergenic processes. Supergenic hematite is the most abundant exemplary mineral found in Alegria area, presenting in different stages of alteration and thus, with different porosity.

Specularite was generated according to two main systems. The main occurrence corresponds to hypidiomorphic to idiomorphic crystals with dimensions varying between 0.02 and $0.3 \mathrm{~mm}$, oriented parallel or subparallel to the plane of the main foliation defining a lepidoblastic or milonitic foliation, associated to high deformation zones. The second occurrence of specularite has crystals similar to those of the main generation, although it is less frequent in the area. These specularites were formed under conditions of low temperature and pressure, for recrystallization and reorientation throughout the foliation of schistosity.
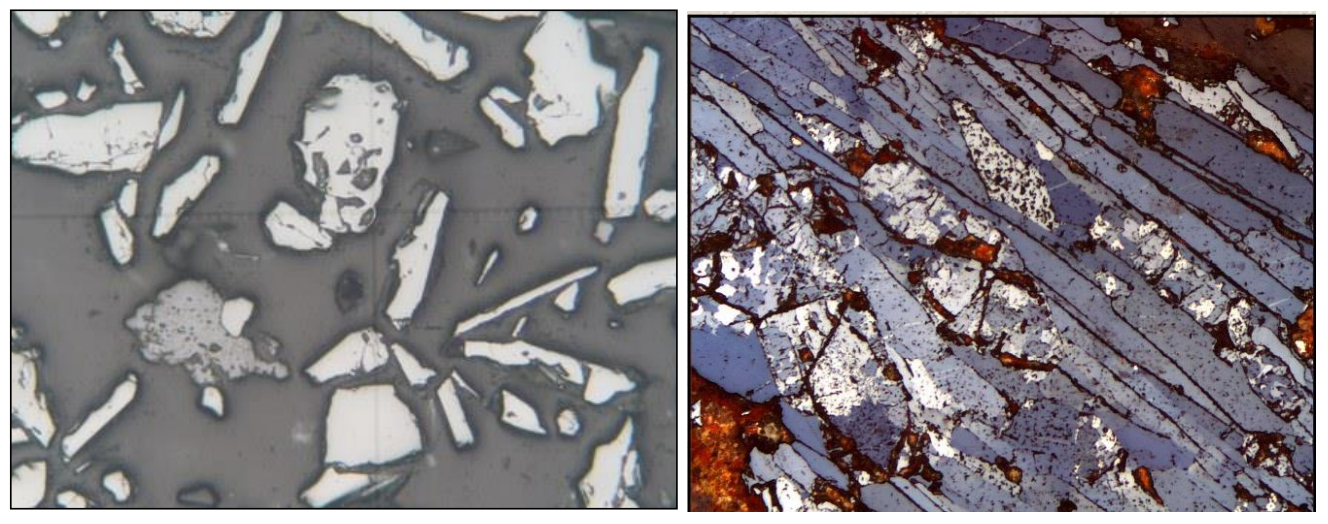

Figure 27- Specular Hematite with lepidoblast and milonitic foliation - under reflect microscope $\times 300$. 


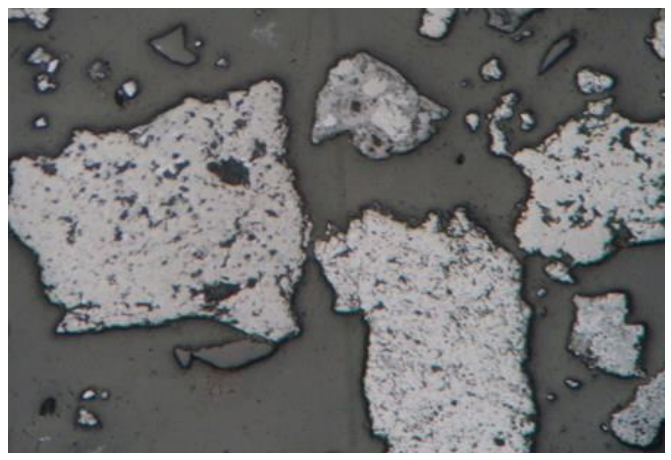

Figure 28 - Martite crystals (HM) under reflect microscope - x300.

Goethitel is the second most abundant iron ore mineral present in the Alegria Mine. It replaces quartz, other iron oxides and iron silicates, without altering the original structure of itabirites. Substitution occurs mainly in the central part of the magnetite crystals, preserving the lamellae of hematite, resulting in a skeletal texture, very common in the area. Goethite also occurs in different forms revealing different forms in acicular and also massive, reniform and stalactic crystals in radiated fibrous aggregates (Figure 29). Thus, it can be found as secondary veins, concretions or crusts.

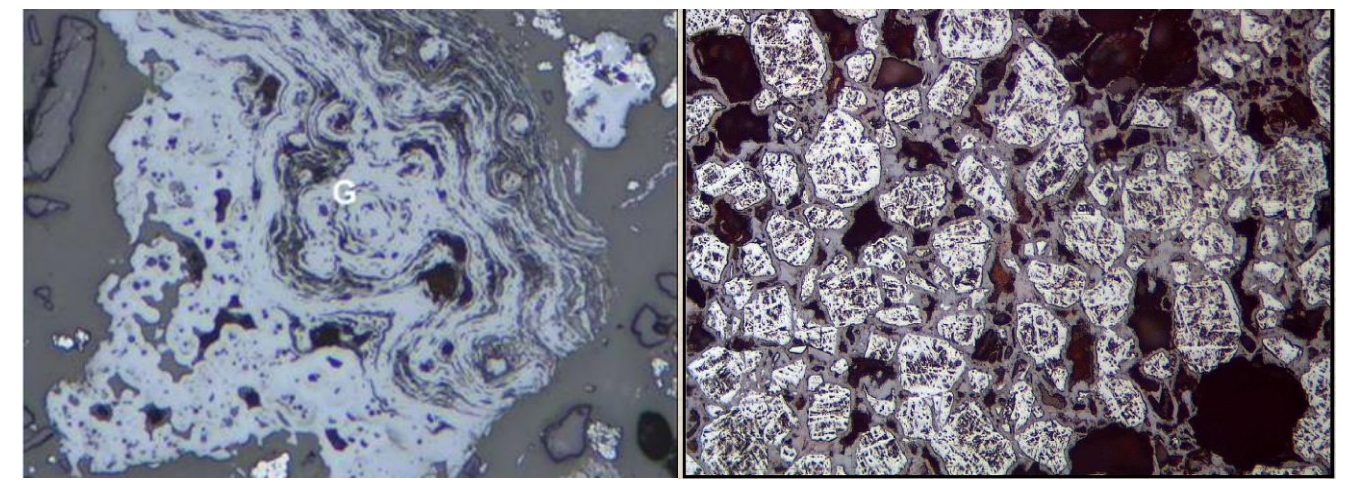

Figure 29 - Porous goethite - under reflect microscope x200 (Rocha, 2008)

Crystals of quartz are the main constituents of the itabirite composition, usually anhedral and associated with iron minerals. Some quartz crystals contain small inclusions of hematite and goethite. The clay minerals can be found in small proportions or even as traces. Some crystals of kaolinite can occur either as prismatic crystals or as a micro aggregate of grains (powder) associated with gibbsite.

\subsection{Structural Geology}

Structural geology of Alegria Mine is composed by open folds with a plunge axis to SE, whose central fold corresponds to a sinformal structure called Alegria Syncline (JANUZZI \& ALKMIN, 1989; ENDO \& CHEMALE Jr., 1992). The length of approximately $6.5 \mathrm{~km}$ hinge zone is 
composed by a vertical axial plane and plunge to $25^{\circ}$ for SE. South limb direction is in general NS and north limb direction is EW. Figure 30 illustrates the structuring of the Alegria syncline and the Samarco's mineral concession.

The hinge zone from major fold increased the thickness in the west part, that it suggest a refolding of a pre-existing (synclinal) structure with original N-S orientation, associated with a west front faulting. Its eastern flank was bent and plunged eastward. The refolding of this structure gave rise to the Alegria Syncline (Figure 31) and associated structures and led to the folding of old structures (MAXWELL, 1972). Associated with major strutures, Sn foliation (schistosity) is penetrative, very evident and marked for preferential orientation of specularitic hematite in Alegria North that has a maximum vallues in 120/45 (Figures 30-A). In Alegria South, it is observed a low dispersion of schistosity, which has an attitude of 70/25 (Figures 30-B). A strong variation in dipdirection of this structure (Figure $30 \mathrm{C}$ ) makes it possible to draw a garland and determine the $\beta$ axis (fold axis). The axis vallue is an order of $100 / 40$. Stereonet of this garland suggests that after the Sn plane there was another folding phase.

Some fractures families were cast in a stereogram (Figure 30D). The first fracture has $290 / 70$, a second family has $40 / 70$ and third has $190 / 80$. The angle between the two joint families suggests that it is a set of shear joints. In contrast to jounts, shear fractures form by an ever-soslight sliding or shearing movement parallel to the plane of fracture.

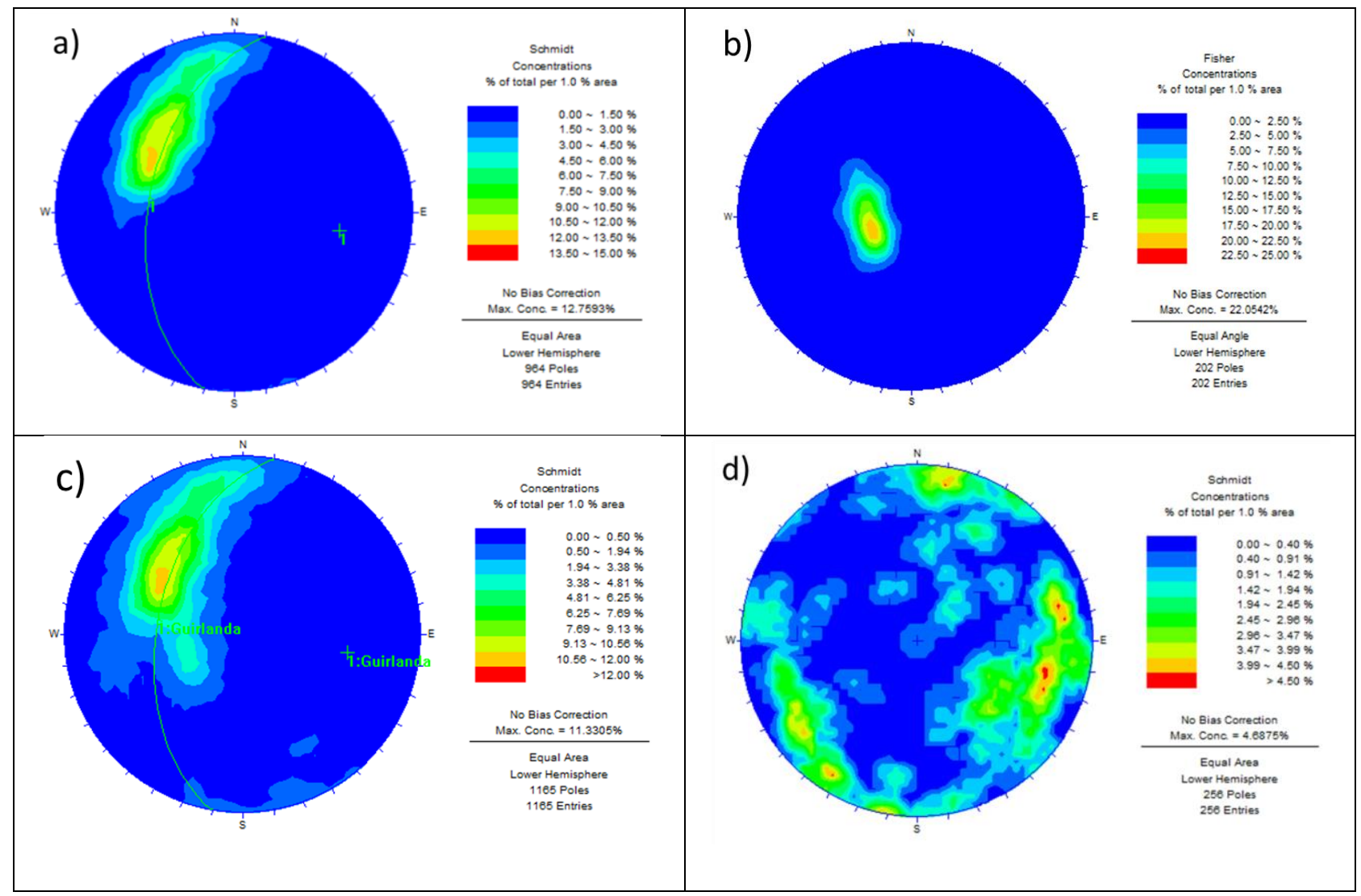

Figure 30 - A) Stereonet of Alegria North and Center itabirites schistosity; B) Alegria South schistosity foliation with $\beta$ axis is on the order of 100/40; C) schistosity plane of the entire deposit and; D) attitude of 3 families of meetings. 


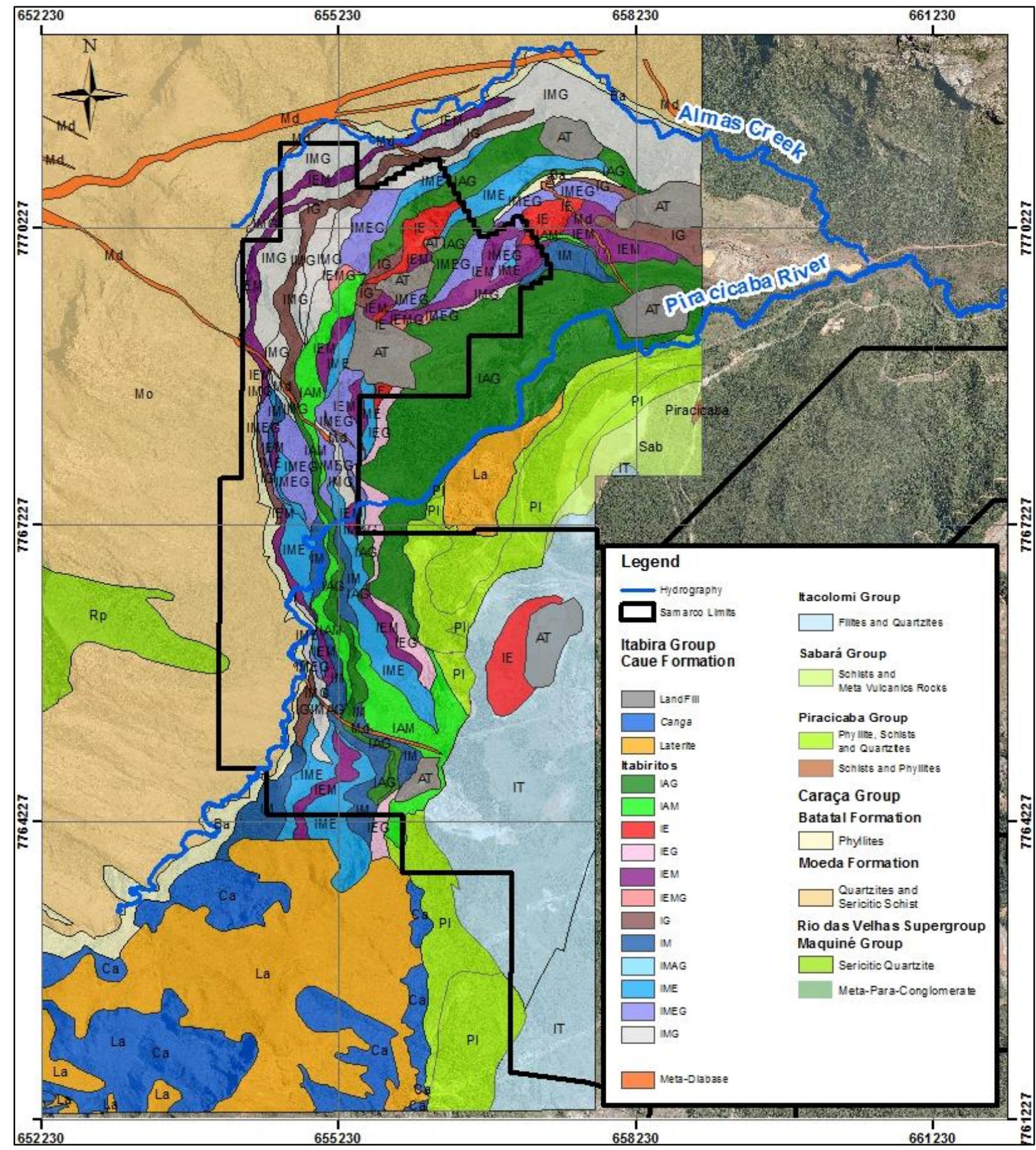

Figure 31- Geological map of Alegria Mine.

\subsection{Tectonic and mineralogical evolution}

During the initial stages of development of the main foliation, generated in the first stage of deformation, magnetite and grunerite was generated, as well as quartz and, more rarely, turmaline and muscovite. Also during this stage, high deformation specularites were generated, developing S-C structures, with the surfaces tending, progressively, to parallelism. 
The increase of oxygen fugacity, associated to the mobilization of fluids, may have contributed to the generation of metamorphic hematite from the original magnetite, at the end of this stage. The presence of stretched crystals of magnetite martitized in association with specularite, present in zones of high deformation, reinforces this hypothesis.

During the second stage of deformation, occurred the recrystallization of new generations of specularite, grunerite and, more rarely, sericite, originated from processes of dissolution by pressure, caused by the deformation (folding). In this stage new minerals arose as a new generation of the quartz, sericite and muscovite.

In the third stage of deformation, under the rupture-ductile shearing, occured a localized formation of specularite, quartz and sericite throughout the two foliations and failure plans. Later in regard to tectono-metamorphic processes, which cause mineralogical transformations, there are superficial processes (weathering) responsible for substitution of magnetite by hematite, goethite and clay minerals (Figure 32 ).

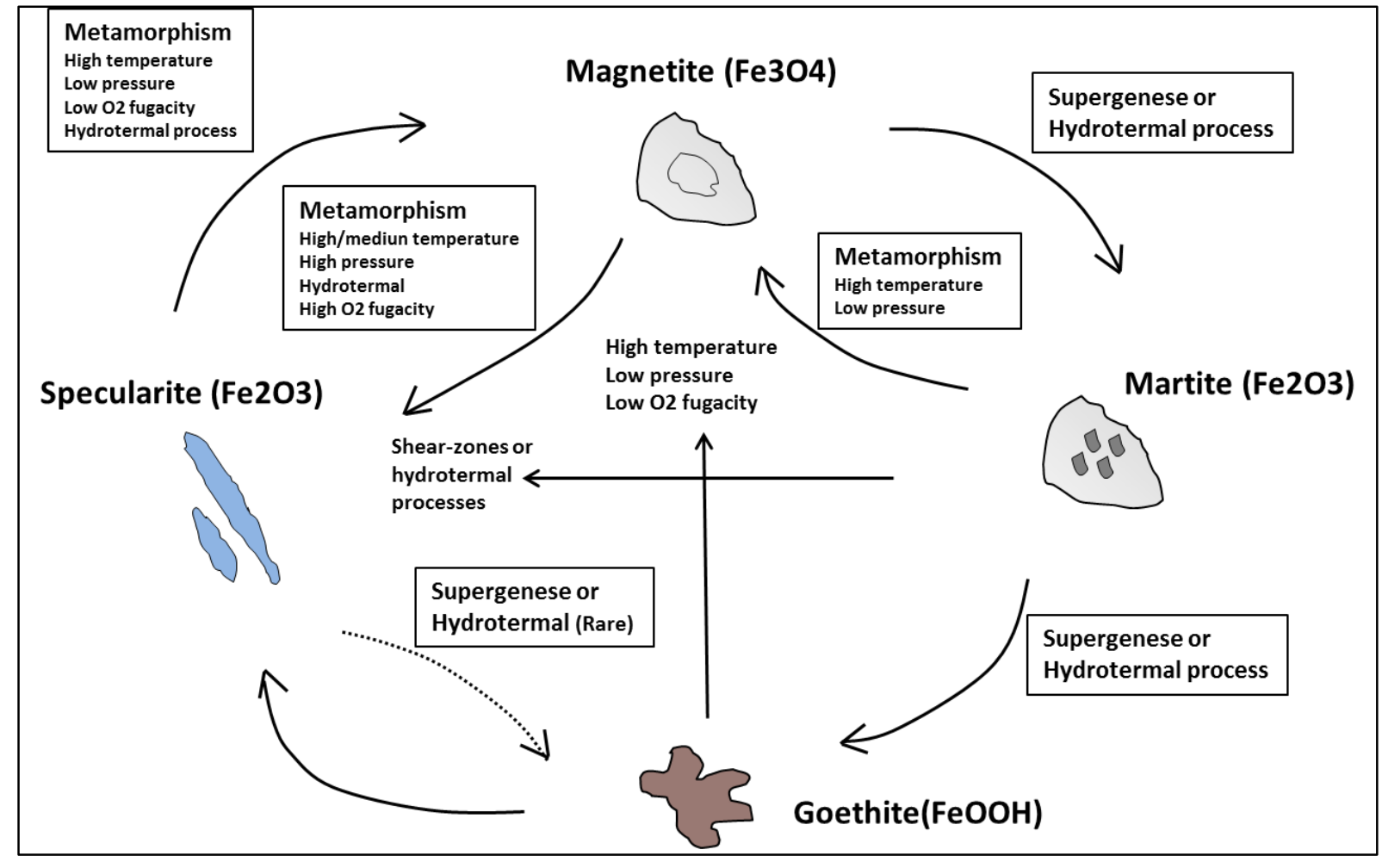

Figure 32- Mineralogical evolution in Alegria Mine

\subsection{D Geological-typological Model}

The data processing realized in the current geological-typological model started in GEMS 6.7 (GEOVIA, 2015) with recognition of regional geology structures, mining scale mapping, exploration borehole loggin and results from mineralogical analyses under reflect microscopy. Geometalurgical characterization of itabirites types defined some groups of: 1) Specularitic 
itabirite (IE); 2) Martitic Itabirite (IM); 3) Goethitic Itabirite (IG); 4) Magnetitic itabirite (IMAG); 5) Martitic-amphibolitic itabirite (IAM); 6) Fresh amphibolitic itabirite (IAF); 7) Goethitic-amphibolitic itabirite (IAG); 8) Martitic-specularitic itabirite (IME); 9) Specularitic-martitic itabirite (IEM); 10) Specularitic-goethitic itabirite (IEG); 11) Martitic-goethitic itabirite (IMG); 12) Goethitic-martitic itabirite (IGM); 13) Martitic-specularitic-goethitic itabirite (IMEG); 14) Martitic-goethitic-specularitic itabirite (IMGE) and 15) Specularitic-martitic-goethitic itabirite (IEMG). Exploration campaings results after 2015, with drilling in high depth, found fresh amphibolitic itabirites (IAF). These fresh itabirites are green colored and can be found usually at $250 \mathrm{~m}$ depths from the surface. They are non-alteration supergene and easily classified by the macroscopic description and typical hardness.

Itabirites bodies have being modeled in vertical and horizontal sections, using the drilling database and fieldwork data. During the first step of geological model, it was determined the grid space. Sections used the local coordinate and theirs names were from survey spacing $100 \mathrm{~m} x$ $100 \mathrm{~m}$ grid $(\mathrm{EW} \times \mathrm{NS})$ in Alegria South and Alegria Center. Survey grid in Alegria North is rectangular with $150 \mathrm{~m} \times 100 \mathrm{~m}$ spacing, where the largest axis has 60 degrees of rotation relative to the north. This rotation is due the main ore body direction in this sector.

The first vertical section in Alegria South starts from south part and the direction is always W-E constrained in northward by Alegria Center. According to the sections, a basal quartzite (QT) is in transitional contact with the Batatal phyllite $(F L)$ that is 300 meters thick and underlying both is the martitic itabirite (IM). The IM ore body is homogeneous, friable and continuous along the drill holes (Figure 33).

Overlying the IM, the martitic-especularitic itabirite (IME) was recognized by specularitic schistosity and in laboratory results test by low values of loss of ignition (LOI). Shear zones and complex folds developed in the IME. At the middle of section there is a thrust fault in tectonic contact with IME and IAM. This tectonic contact can be identified in some boreholes and outcroups. Thus, differences itabirite's typology repeats along the section until the upper transitional phyllite contact. The phyllite located on the top is recognized by Piraciba and Itacolomi groups, in the east part of section. 


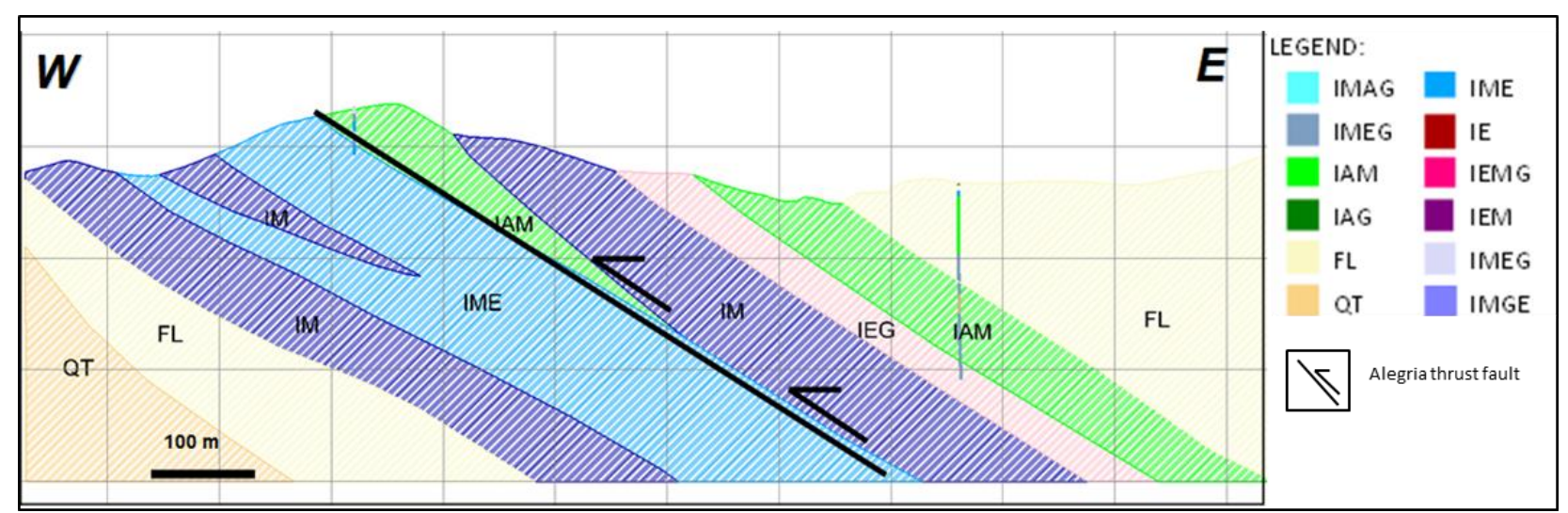

Figure 33- Typical cross section in Alegria South

Alegria Center is recognized structure by hinge zone. The main differences between Alegria Center and Alegria South in this area are the anphibolic-goethitic itabirite (IAG) at the middle of cross section (Figure 34). Mineralogical analyses came from drillholes show high magnetite grades in some areas. An intrusive rock composed is also found in this sector.

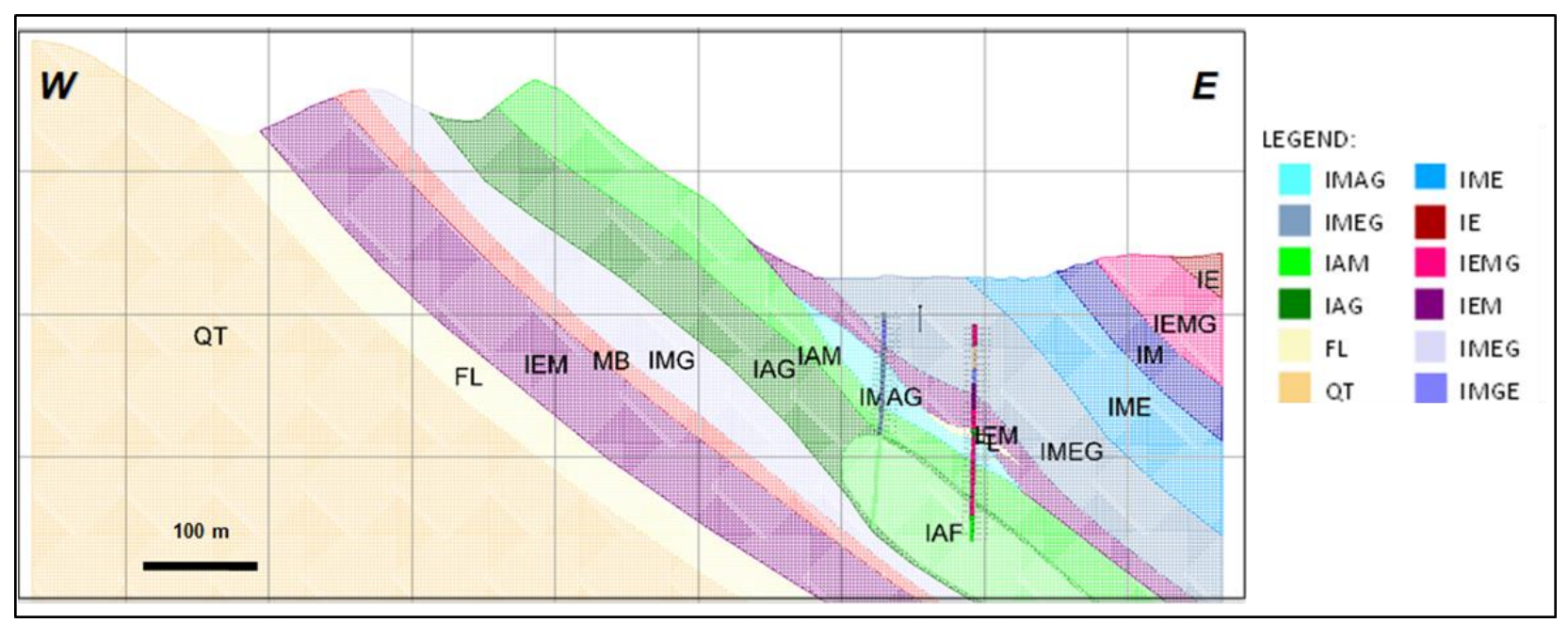

Figure 34- Typical cross section in Alegria Center.

Alegria North is about $3,000 \mathrm{~m}$ stratigraphic thickness (Figure 35). This thickness is probably due largely to folding and faulting. Large bodies of amphibolitic itabirite are common in Alegria North but concordant lenses and layers of specularitic itabirite are locally common. Weathering tends to soften and enrich itabirite by leaching silica.

The contact of the itabirites with the underlying Batatal Formation is gradational conformable. Additionally, the contact on the top by phyllites from Piracicaba Group is everywhere an erosional unconformity. Amphibolitic itabirite occurs mainly in Alegria NW area. This area was recognized for compact itabirites which were also determined by pseudomorphic amphibole. Geological-typological model has revealed ductile shear zones marked by penetrative foliation in the middle of section in figure 35. Normally, shear zones area is composed by especularitic itabirite orebod, which it was a result of Alegria fault stress. 


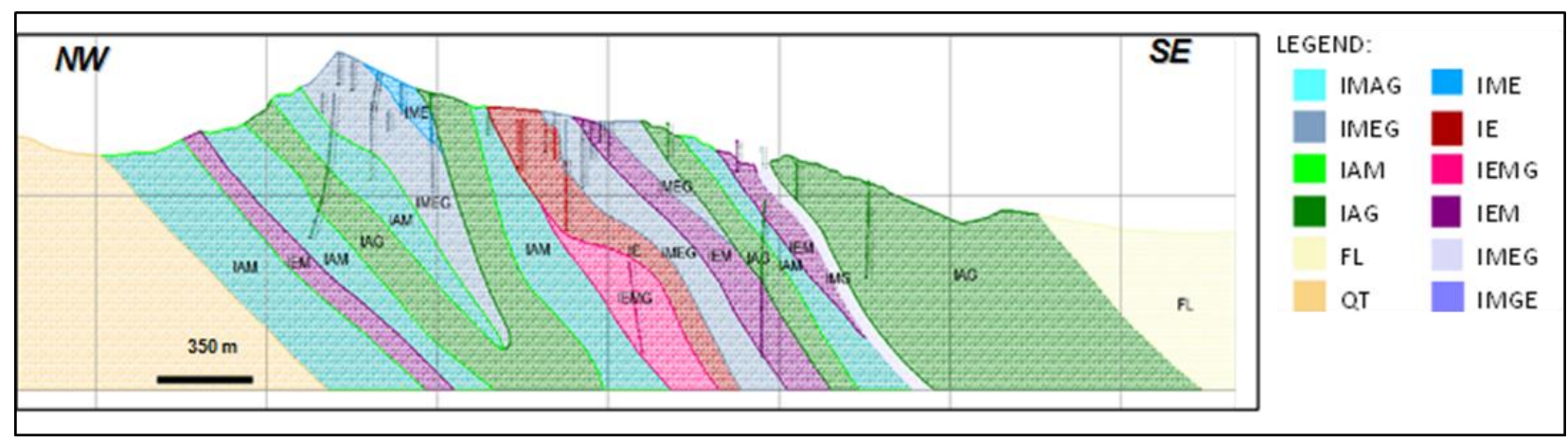

Figure 35 - Typical cross section in Alegria North

Mineralizations zones are located, exclusively, in certain types of itabirites and stratigraphic horizons, which can be considered stratigraphic guides in the 3D model. The main geological structures and weathering controled the mineralogical and chemical parameters in Alegria model (Figure 36). Generally, itabirites trend approximately N-S, with dip angles varying from $20^{\circ}$ (Alegria South) to $50^{\circ}$ (Alegria North) and verging to the east and southwest. They can be grouped into three distinct geological and typological domains: the first one, located onthe west, where there were the least hydrated itabirites - which, therefore, are the most specularitic ones (martitic-specularitic and specularitic-martitic). The second domain, located in the most central region, is mainly composed of amphibolitic, martitic-goethitic and martitic itabirites, therefore being a more hydrated domain where specularite is absent. In the third domain, located to the east, specularite is again present in large proportions and may even be the only predominant mineral, as in the specularitic type present at Alegria South. 


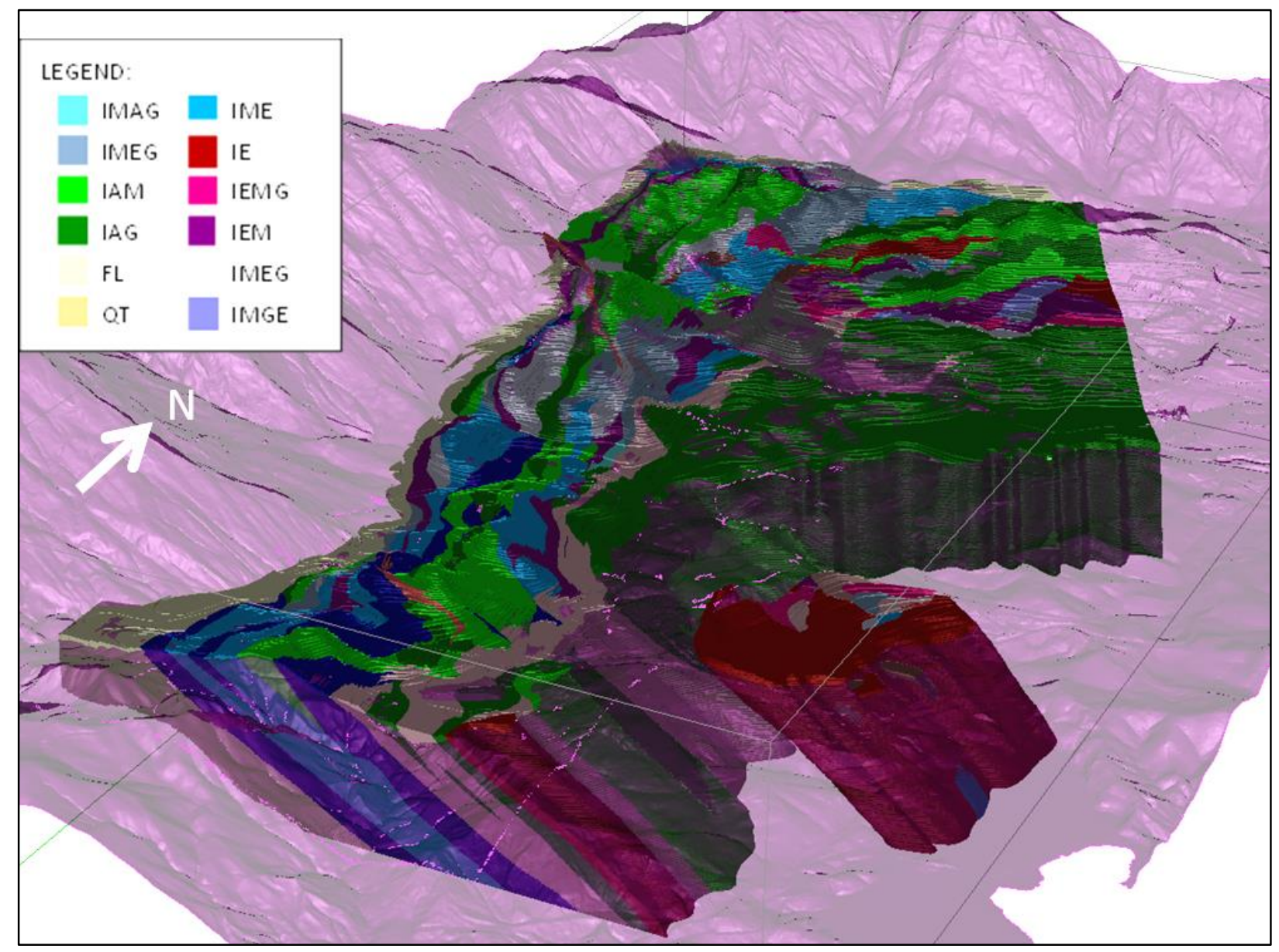

Figure 36 - Complete geologic-typological modeling in Alegria Mine.

\section{Conclusions}

Visualization of ore body geometry and major structures in the Alegria Mine under different angles consist of an important tool for geological information interpretation. The 3D geologicaltypological model represents the geometrical units of itabirites, phyllites and quartzites that were controlled by main structures in Alegria Mine obtained from the mapping and informations from boreholes.

The minerological/textural evolution of the itabirite of the Alegria Mine is linked to temperature and pressure conditions as a result of diferents phases of tectonic and metamorphic process. Subsequently the process of mineralogical alteration succeeded by the supergenesis governed the iron oxides and hydroxides transformation.

3D geological-typological model is used as basis to estimate chemical, mineralogical and granulometric grades inside resource model, through the definition of different domains for geostatistics analysis. In addition of using the model for common activities of mine planning, geological-typological model is used as fundamental basis for the studies of applied sciences as geotechnics and hydrogeology.

Other important application of the geological-typological model is in the geometalurgical studies. Some important applications and good results are being achieved by Samarco's team, 
due to very good correlations of the geological genesis and mineralogical features of the ore types with the behavior at the several stages of the beneficiation process.

\section{Acknowledgements}

The authors are grateful for technical discussions with Leonardo Bonfioli, Rafael Rodrigues and Junia Rocha. This work was supported by Samarco Mineração SA.

\section{References}

Alkmin, F.F, Evangelista, M.T., 1988. Sobre a história da deformação dos metassedimentos do Supergrupo Minas e Grupo Itacolomi no Quadrilátero Ferrífero, Minas Gerais. Universidade Federal de Ouro Preto, Ouro Preto, Minas Gerais

Endo, I., Chemale, F. 1991 Projeto Sinclinal de Alegria aba NE. Convenio UFOP/Samitri, relatório interno, $13 p$

GEOVIA, 2015, Software GEMS 6.7, 20 Vancouver, B.C., Canada, V6E 3X1.

Hoefs J., Muller, G., Schuster, A.K., 1982. Polymetamorphic relations in iron ores from the Iron Quadrangle, Brazil: the correlation of oxygen isotope variations with deformation history. Contributions to Mineralogy and Petrology, 79: 241-251

Januzzi, A., Alkmin, F.F. 1989. Geologia estrutural da Mina de Alegria. Convenio UFOP/Samitri, Relatório interno. 32p.

Maxwell, C.H. 1972. Geology and ore deposits of the Alegria Distric, Minas Gerais, Brazil.

Rocha, J. M. P., 2008, Definição da Tipologia e Caracterização Mineralógica e Microestrutural dos Itabiritos Anfibolíticos das Minas de Alegria da Samarco Mineração S.A. - Minas Gerais. Belo Horizonte: Escola de Engenharia da UFMG. 2vol. Tese de Doutorado apresentada ao Curso de Pós-Graduação em Engenharia Metalúrgica e de Minas da Universidade Federal de Minas Gerais, 460p.

Samarco Mineração S.A., 2012, Competent Person Report, Mariana (Relatório Interno), 54 p.

Veríssimo, C.U.V., 1999: Jazida de Alegria: Gênese e Tipologia dos Minérios de Ferro; Minas 3, 4 e 5 Porção Ocidental. 2vol. Tese de Doutorado. Rio Claro: Instituto de Geociências e Ciências Exatas da Universidade Estadual Paulista. 


\section{CHAPTER 6 - HYDROGEOLOGICAL CONCEPTUAL MODEL FOR ALEGRIA MINE, EAST PART OF QUADRILÁTERO FERRÍFERO, MINAS GERAIS, BRAZIL}

João Paulo Chiste-Costa, Alexandra Vieira Suhogusoff, Luiz Carlos Ferrari

Abstract

Groundwater management is a crucial task to be considered in mining operations with the purpose to access ore reseves located below water table. Alegria Mine is settled in Cauê Formation, an important geological unit inserted in the eastern part of the mineral province Quadrilátero Ferrífero (Minas Gerais State, Brazil) that is plenty of iron ore. Cauê Formation is composed predominantly by metamorphic banded iron formations (itabirites), and corresponds to the main aquifer of the region. Since iron ore extraction can be reachable only with dewatering process, usually numerical groundwater models are employed to scale pumping programs. Preceding numerical step, a hydrogeological concept model need to be conceived in order to represent as accurately as possible the real space to be modeled, in other words, the hydraulic aquifer behavior in real world. Construction of conceptual model for Alegria Mine involved monitoring, analysis and integration of data sourced from geological and topographic maps, meteorological stations (climate parameters), fluviometric stations, spillways and flowtracker log (streams and rivers properties), observation and pumping wells (geological and construction profiles, water levels, hydraulic parameters). Hydroestratigraphic units were defined and tematic maps prepared to support numerical groundwater model and scenarios simulations (dewatering alternatives).

\section{Introduction}

The Quadrilátero Ferrífero aquifers are composed by different lithological units, with relatively similar hydrodynamic properties, generally delimited at the top and bottom by low permeability layers in stratigraphic succession. Among aquifers in the region, Cauê aquifer has been systematically studied due to the reserve groundwater potential (BEATO et al., 2005).

Cauê aquifer consists of several types of itabirite, quartzite and pulverulent hematitites, with high porosity and hydraulic conductivity (SILVA et al., 1994). It is a regionally unconfined aquifer, but in some portions it is confined, with high levels of interstitial porosity, at times with fissural porosity superimposed, assigning to aquifer a dual porosity characteristic.

Many studies related to Cauê aquifer come from hydrogeological analyses carried out by mining companies, whose objective is to implement mine dewatering through pumping wells to access ore reserves below water levels

Samarco Mineração S.A., a Brazilian iron ore mining company, demands for a dewatering program implementation in Alegria Mine to get access to $40 \%$ of ore reserve. In general numerical 
groundwater modeling is used to understand groundwater behavior as to test dewatering scenarios based in pumping solutions. Nevertheless, numerical models are useless if unsuitable conceptual models are conceived.

This paper presents the hydrogeological conceptual model for Alegria Mine, whose construction was based on different sources of data (geological and topographic maps, meteorological, fluviometric, observation and pumping wells). Conceptual model summarizes the natural conditions of a considered rock mass, which is a simplified representation of the main mechanisms that control groundwater flow. It includes a hydraulic balance for Piracicaba River catchment and hydraulic parameters attribution to the hydrostratigraphic units. These both elements provide hydrogeological evaluation for future projection of different scenarios of aquifer drawdown, and other interventions related to mining operations.

\section{Site Description}

The study area is located in the eastern portion of Quadrilátero Ferrífero (Minas Gerais State, Brazil), The distance from Alegria Mine to Belo Horizonte is approximately $150 \mathrm{~km}$ following the BR-356 Road (Figure 37). The nearest towns are Mariana (32 km) and Santa Barbara (40 $\mathrm{km}$ ). Mining operations subdivide geographically the study area in three regions: Alegria North, Alegria Center and Alegria South.

Alegria Mine is an iron ore deposit delimited by Proterozoic tectonic belts from Brazilian process and by neoproterozoic platform sequences of Minas Supergroup (ALMEIRA, 1977 and ALKMIN \& MARSHAK, 1998). Metamorphic banded iron formations (itabirites) occurring in Alegria Mine are folded in a huge syncline, whose hinge is in Alegria North, responsible for changing stratification orientation from N-S to E-W. According to Alegria Mine stratigraphic column proposed by Maxwell (1972), iltabirites from Cauê Formation overlies quartzites and phyllites from Batatal Formation. On the top quartzites and phylites from Piracicaba Group overlies itabirites from Cauê Formation by a discordant contact.

Itabirites are divided in several lithotypes based on their mineralogical composition, but mainly there are three subtypes: Martitic Itabirites (IM), Specularitic Itabirites (IE), Goethitic Itabirites and Anfibolitic Itabirites (IA). Those three units represent the main aquifers found in the study area, although the anfibolitic one is considered as the lowest permeability unit due to its mineralogical composition and alteration products (CHISTE-COSTA et al., in preparation Chapter 5). Quartzites, phyllites, schists and metabasic intrusive rocks are considered as aquitard because their low permeabilities, even though rock bodies may present high fracturing level, weathering and oxidation. 


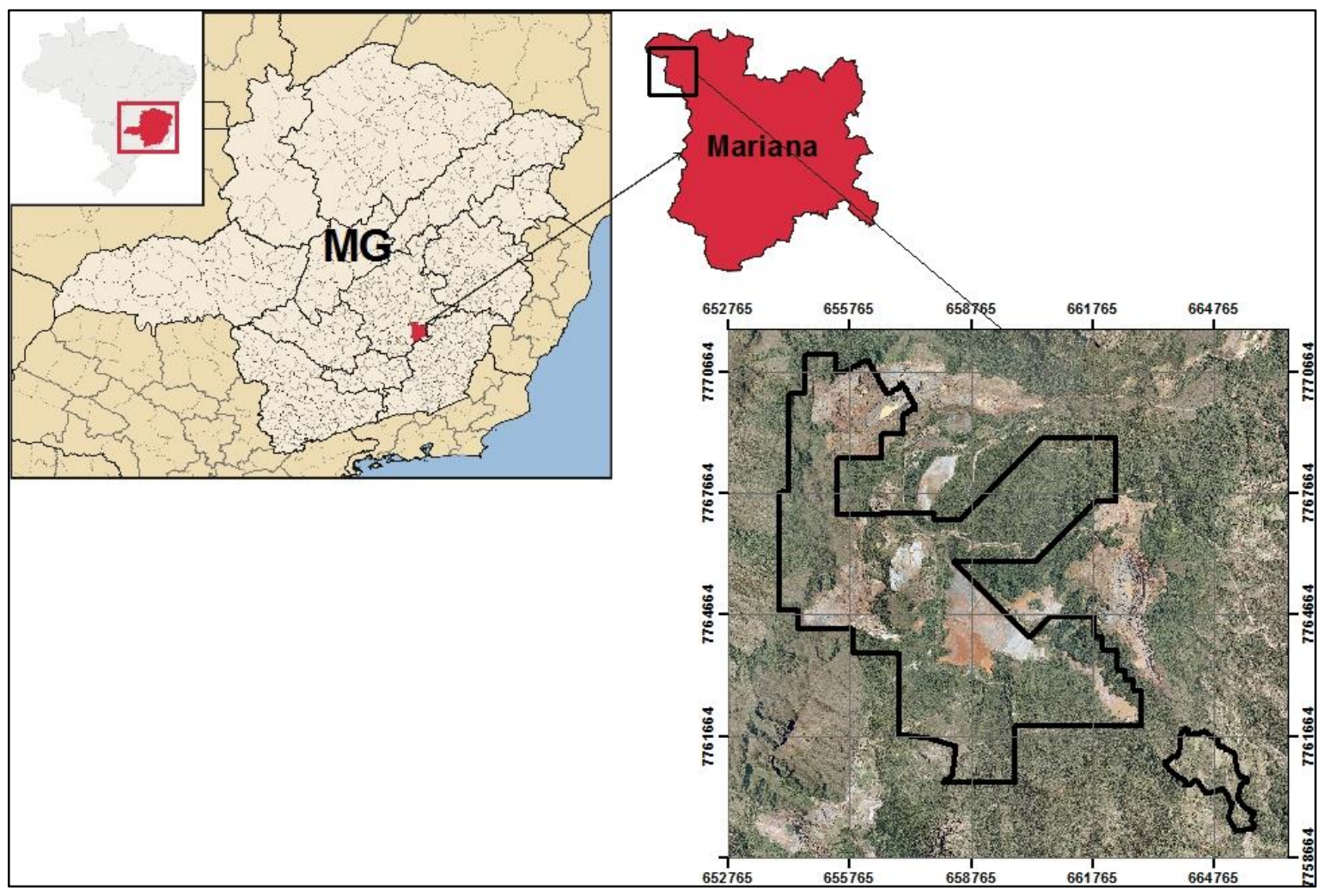

Figure 37- Location Map of the Alegria Mine and Samarco's mineral tenures

\section{Hydrogeology}

Cauê aquifer is composed of several types of itabirite and pulverulent hematite, with high porosity and hydraulic conductivity, in the order of $10^{-5} \mathrm{~m} / \mathrm{s}$ (MOURÃO, 2007). Porosity can vary between 3 and $41 \%$. It is a regionally unconfinied aquifer, but in some portions it is confined, with high interstitial porosity and also marked by zones of fissural porosity (SILVA et al., 1994). Cauê Aquifer thickness is varied between $300 \mathrm{~m}$ and $2000 \mathrm{~m}$, same thickness of geologic unit described by Dorr (1969), due to the area structural complexity represented by faults and folds.

Cauê aquifer is anisotropic in terms of hydraulic conductivity. Additionally, heterogeneity is observed by means of permeability and pumping tests, in which transmissivity ranges from 0.01 $\mathrm{m}^{2} / \mathrm{d}$ to $1.5 \mathrm{~m}^{2} / \mathrm{d}$ (SILVA et al., 1994; MOURÃO, 2007).

Geoestrutural (2004) and MDGEO (2008) have mapped existing springs in Cauê Aquifer for Alegria Mine and contiguous regions. Usually this aquifer discharges in several springs with low flow $\left(2 \mathrm{~m}^{3} / \mathrm{h}\right)$, but in some situations, where structural control prevails, flow rates can vary from $100 \mathrm{~m}^{3} / \mathrm{h}$ to $120 \mathrm{~m}^{3 / h}$.

The confining surrounding rocks of Cauê Aquifer are composed of phyllites and quartzites with relatively low hydraulic conductivity: for Batatal Formation (phyllites) it corresponds to $9.010^{-}$ ${ }^{8} \mathrm{~m} / \mathrm{s}$ on average, depending on rock weathering conditions (MOURÃO, 2007). This value is considered quite high for rocks of this nature and it is probably associated with more superficial portions of rocky massif. Significantly lower values, at around $10^{-9} \mathrm{~m} / \mathrm{s}$, are reported for quartzites 
of the current formation. Phyllites from Piracicaba Group also comprise lithotypes of low hydraulic conductivity, up to $1.010^{-8} \mathrm{~m} / \mathrm{s}$, and insignificant recharge to aquifer is expected from them.

Therefore, lithotypes belonging to Batatal Formation and Piracicaba Group form zones of low hydraulic conductivity, which conditions groundwater flow through the permeable itabirites. Metabasites dikes can be found in the study area and behave as important hydraulic barriers that promote hydraulic barrier. Pronounced differences in groundwater levels, at short distances from different sides of intrusive dikes, are commonly interpreted as indicative of impermeable rocks.

Relative subdivision of the hydroestratigraphic units of study area was defined taking into account mineralogical composition of the different itabirites (Cauê Aquifer) and confining rocks (phyllites and quartzites). Quartzites from Moeda Formation located in the western portion of Alegria Mine were defined as aquitards. Phyllites from Batatal Formation and phyllites and quartzites from Piracicaba Group were classified as aquicludes (MOURÃO, 2007).

\section{Climate}

According to Köppen climatic classification, the region presents a tropical altitude climate (mesothermic), with wet summers and dry winters. Evaluate the data come from six metherological station along the study area there are two distinct period with a rainy season from October to March and a dry season from April to September (Figure 38). The annual average precipitation is $2,189 \mathrm{~mm}$.

About $85 \%$ of the precipitation occurs in a six months period, from October to March (a single-modal distribution). Regionally, annual evapotranspiration is approximately $35 \%$ lower than the annual average precipitation (or $766 \mathrm{~mm} /$ year). Considering monthly distribution, potential evapotranspiration exceeds precipitation on the driest period of the year, resulting in an Annual Effective Precipitation (difference between precipitation and real evapotranspiration of approximately $660 \mathrm{~mm} /$ year. 


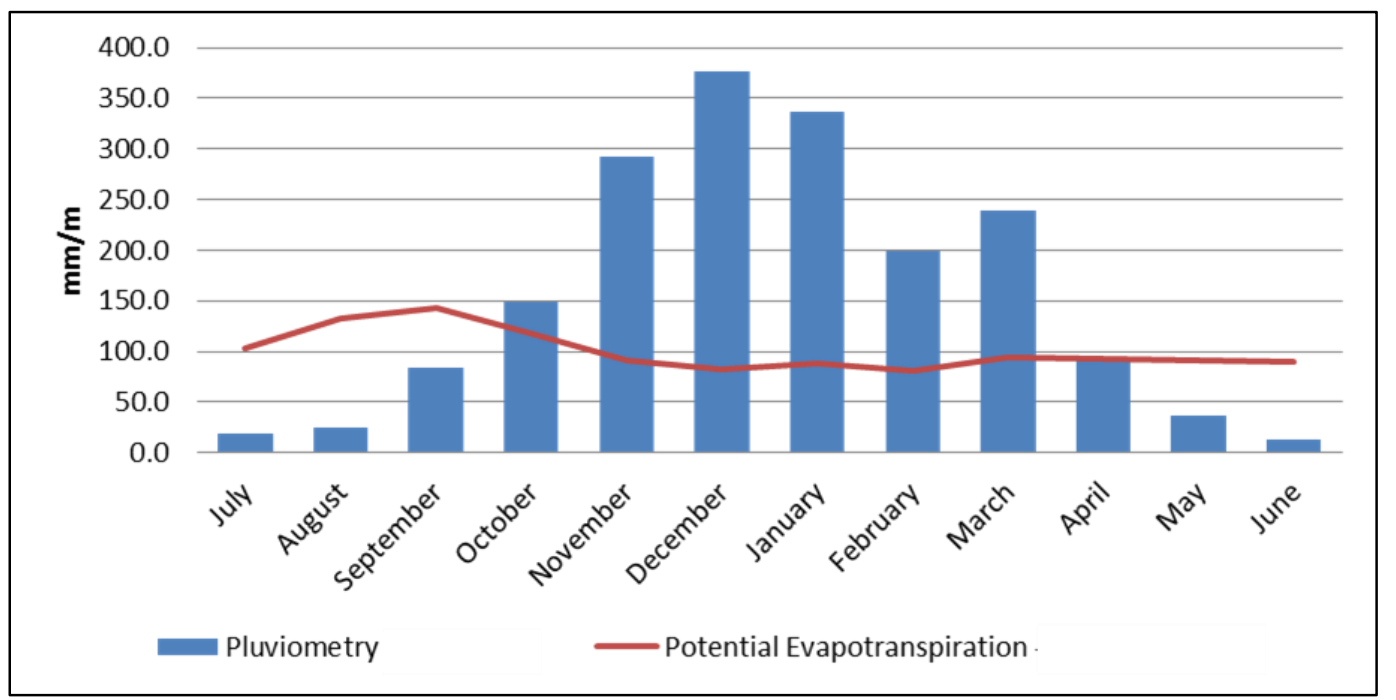

Figure 38- Precipitation and potential evapotranspiration average from 2007 to 2016.

\section{Hydrography}

\subsection{Piracicaba River}

Alegria Mine is located in Piracicaba River basin, which has its source in "Serra do Caraça". Piracicaba River crosses the mine area with a SW-NE direction, separating North and Center Alegria sectors from South Alegria. The river tributaries Palmital creek, João Manuel creek, Macacos creek and Macaco Barbado creek also intercept the study area and all are instrumented with spillways. Almas Creek is the tributary further downstream from Piracicaba River. The Piracicaba upper sub-basin, where study area is inserted, has $12 \mathrm{~km}^{2}$, measured from the river source to its confluence with the Almas creek (including the contribution area of Almas Creek).

Piracicaba River flow direction within the study area is NE, varying in elevation from 1220 to $920 \mathrm{~m}$, at the confluence point with Almas, located in at the extreme NE, outside the Samarco's property limits. Figure 39 shows the hydrographic context of the target area. 


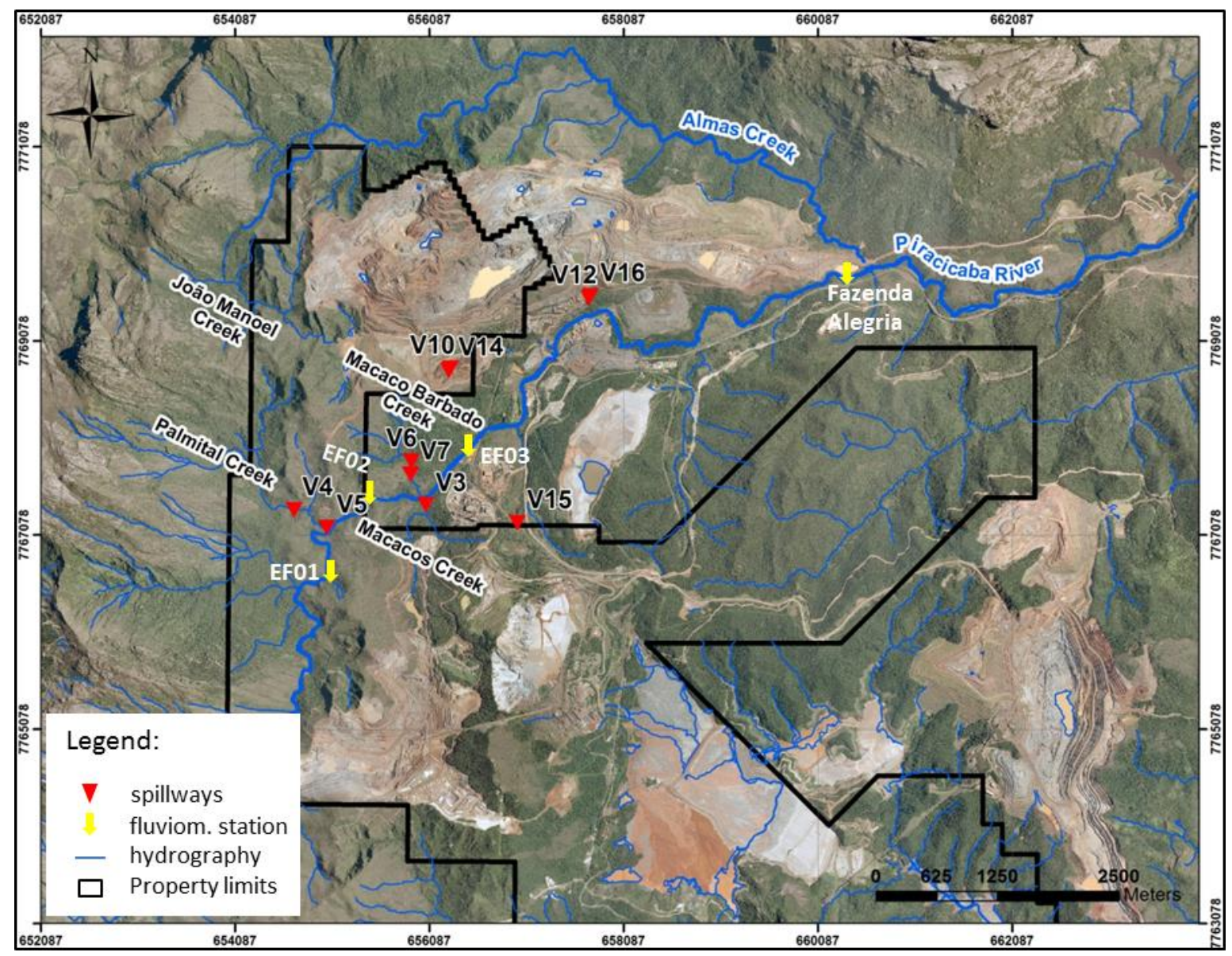

Figure 39- Hydrographic Context of the Study Area.

The fluviometric monitoring shows the average flow recorded in Piracicaba River (Figure 40). A significant increase in flow is observed from Stations EF01 to EF02, in part because of a contribution of Palmital creek. Analyzing data from dry season (between May and September), one observes that flow increase measured from EF01 to EF02 exceeds contribution from the two tributaries, indicating Piracicaba River receives an additional flow from aquifer in this part.

There is a flow reduction between Stations EF02 and EF03, in part due to water deficit upstream to Station EF03, where there is a dam and a superficial pumping station, which compromised a better evaluation of river and aquifer interaction in this region.

A detailed analysis of hydrograms indicates a base-flow around $250 \mathrm{~m}^{3} / \mathrm{h}$ to Piracicaba river, considering a contribution area of $28 \mathrm{~km}^{2}$ to Station EF01 and $500 \mathrm{~m}^{3} / \mathrm{h}$ for a contribution area of $37 \mathrm{~km}^{2}$ to Station EF02, resulting in an estimated base-flow to these areas of at least 750 $\mathrm{m}^{3} / \mathrm{h}$ (Figures 40 and 41 ). 


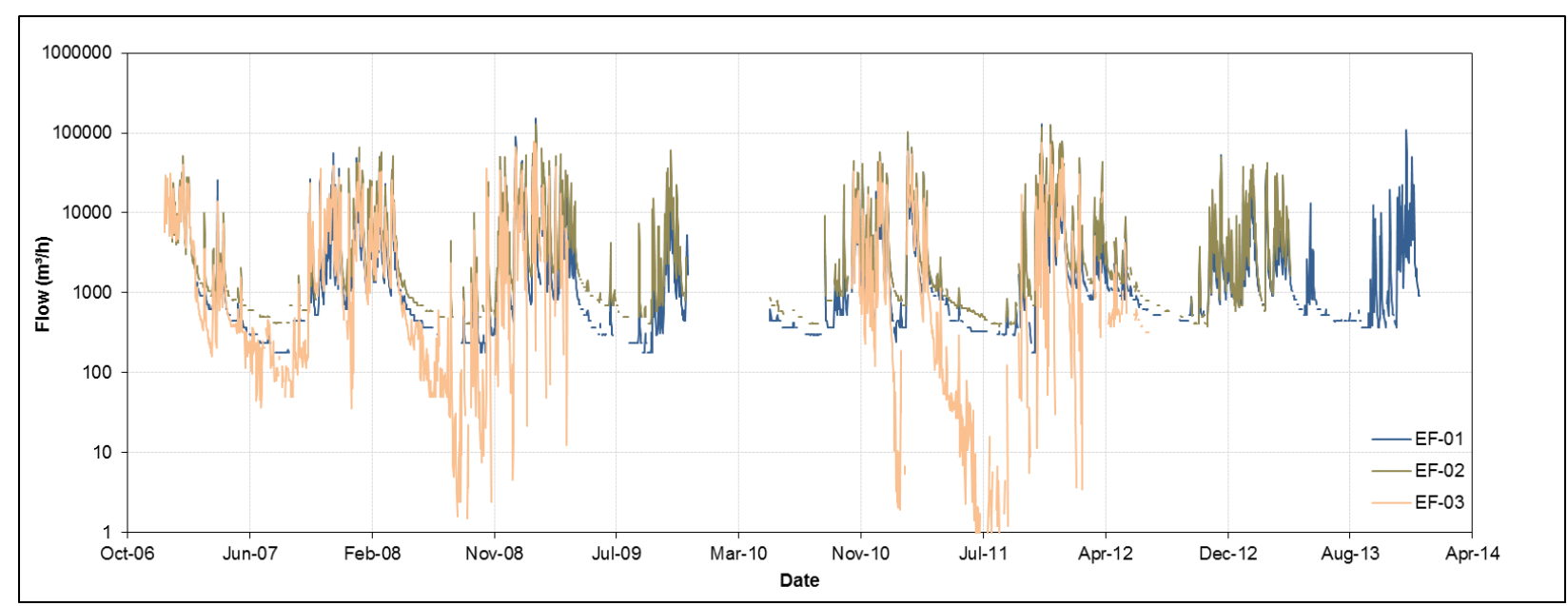

Figure 40- Piracicaba River hydrography

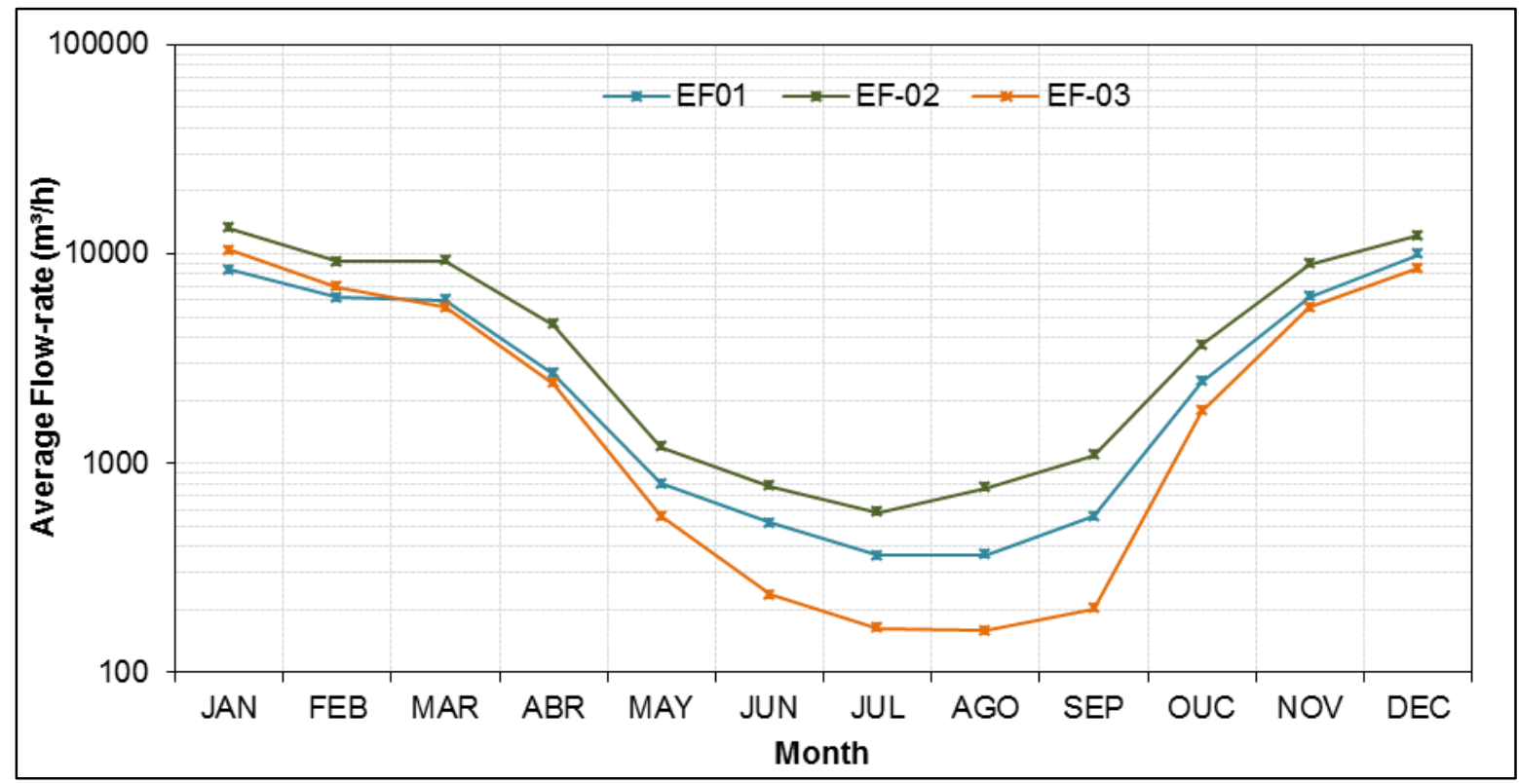

Figure 41- Hystorical average of Piracicaba River flow-rate im EF01, EF02 and EF03 (from 2006 to 2016).

Monitoring data from Fazenda Alegria Station downstream (Figure 42), that was monitor by CPRM between 1971 to 1977 (ANA, 2016) indicates a mean flow to the Piracicaba River around $4,400 \mathrm{~m}^{3} / \mathrm{h}$, a flow rate below to that measured in upstream stations. However, analyzing data separately for the dry period, is noticeable that mean flow rate in Fazenda Alegria Station is, in fact, greater than the other three stations upstream. The difference of 30 years between the monitoring periods in Alegria Station to EF01, EF02 and EF03, the data suggests, as expected, a flow increase in the considered portion of Piracicaba river. Therefore, the estimated base-flow to Piracicaba River inside the area is $1,400 \mathrm{~m}^{3} / \mathrm{h}$. 


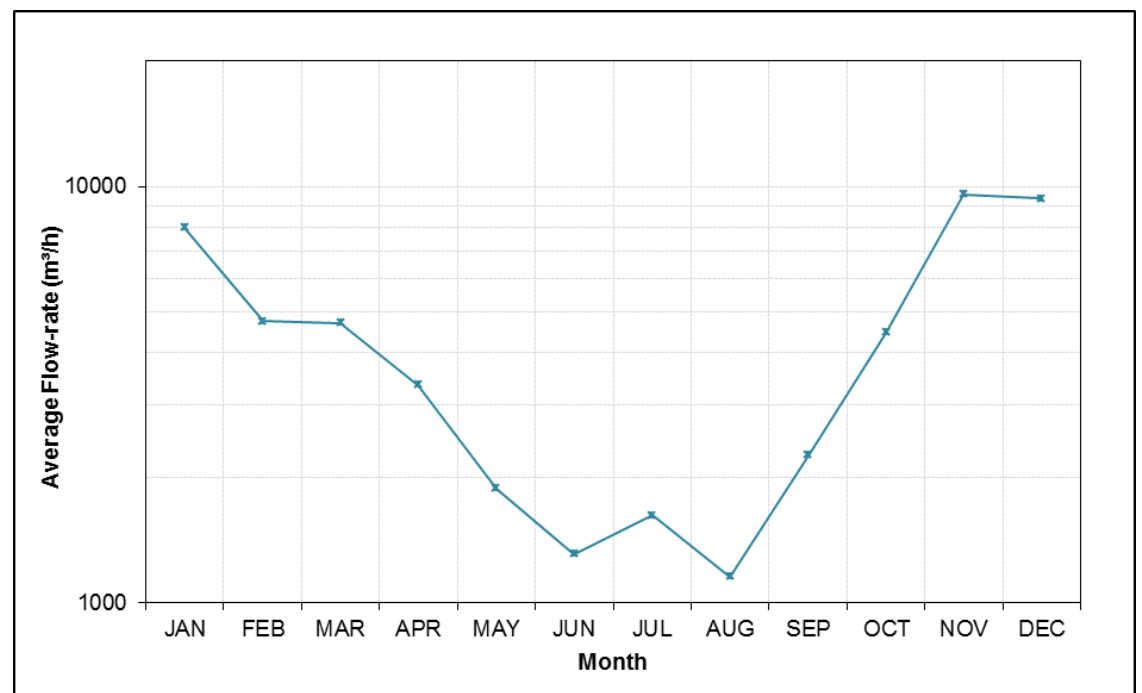

Figure 42- Piracaciba mean flow rate calculated from measurements taken at Fazenda Alegria fluviometric station (from 1971 to 1977).

\subsection{Piracicaba's tributaries}

Piracicaba tributaries were monitored by spillway and flowtracker, as indicated by figure 43. Three creeks (Macaco Barbado, Macacos and Palmital creeks) were considered as effluent water bodies, that is, they act as discharge areas, receiving water from aquifer.

Flow rates in Macacos creek follows roughly precipitation variation, showing low flow in dry season (around $90 \mathrm{~m}^{3} / \mathrm{h}$, equivalent to the creek's base-flow), when creek is effluent on this portion. The approximate drainage area that contributes to V3 spillway is about $4.1 \mathrm{~km}^{2}$ (Figure 44).

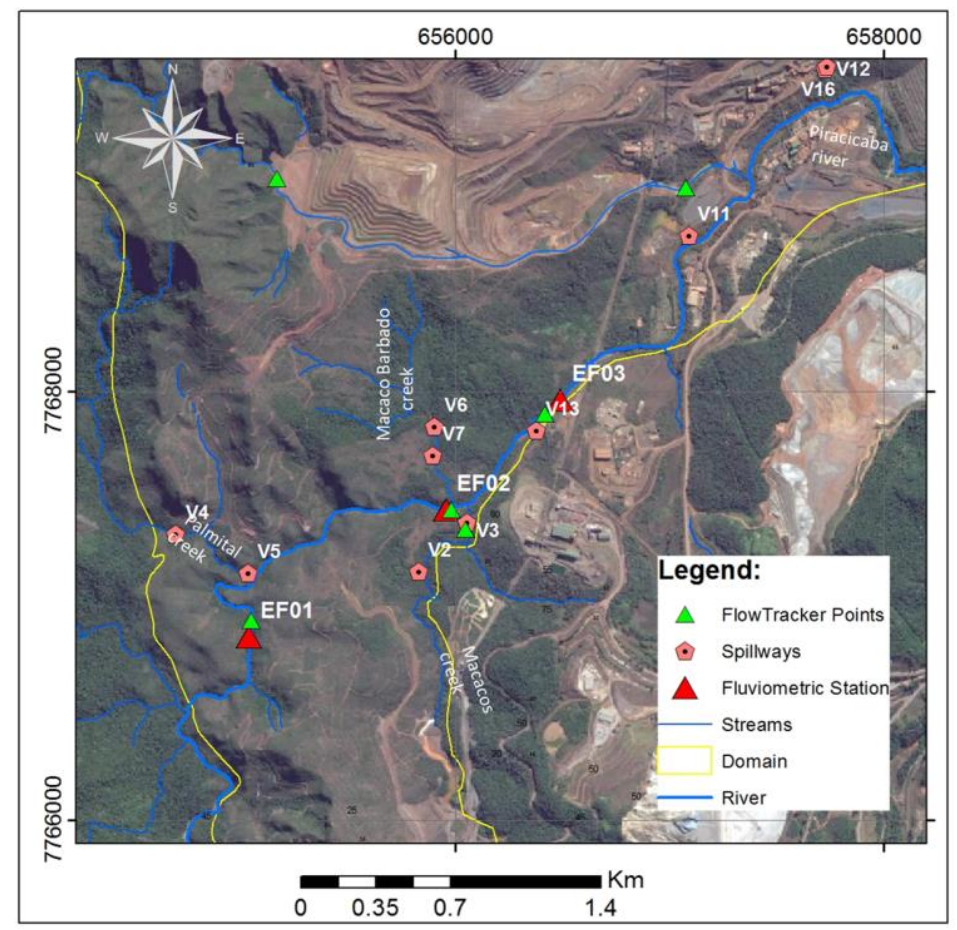

Figure 43- Piracicaba River tributaries map with points monitored by spillways and flowtracker 


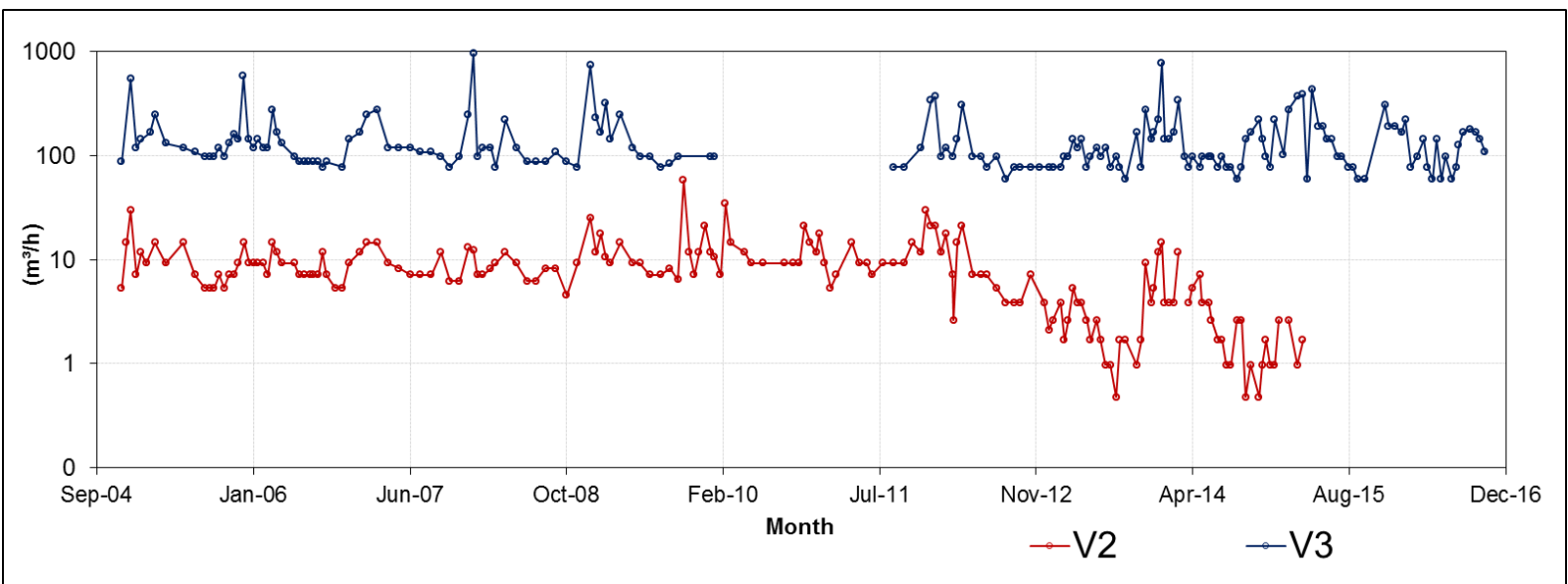

Figure 44- Macaco creek hydrogram based on data from spillways V2 and V3.

Palmital creek shows higher flow rates than Macacos creek (Figure 45), with average annual flow around $250 \mathrm{~m}^{3} / \mathrm{h}$ near confluence point with Piracicaba river. One observes a average flow increase of around $40 \mathrm{~m}^{3} / \mathrm{h}$ between spillways V4 (upstream) and V5 (downstream) in the period 2005-2016. Part of this increment is originated from the contribution of a tributary of Palmital creek between these two spillways. In dry season, this difference varies between $10 \mathrm{~m}^{3} / \mathrm{h}$ and $20 \mathrm{~m}^{3} / \mathrm{h}$, suggesting that this Palmital creek is effluent in this portion.

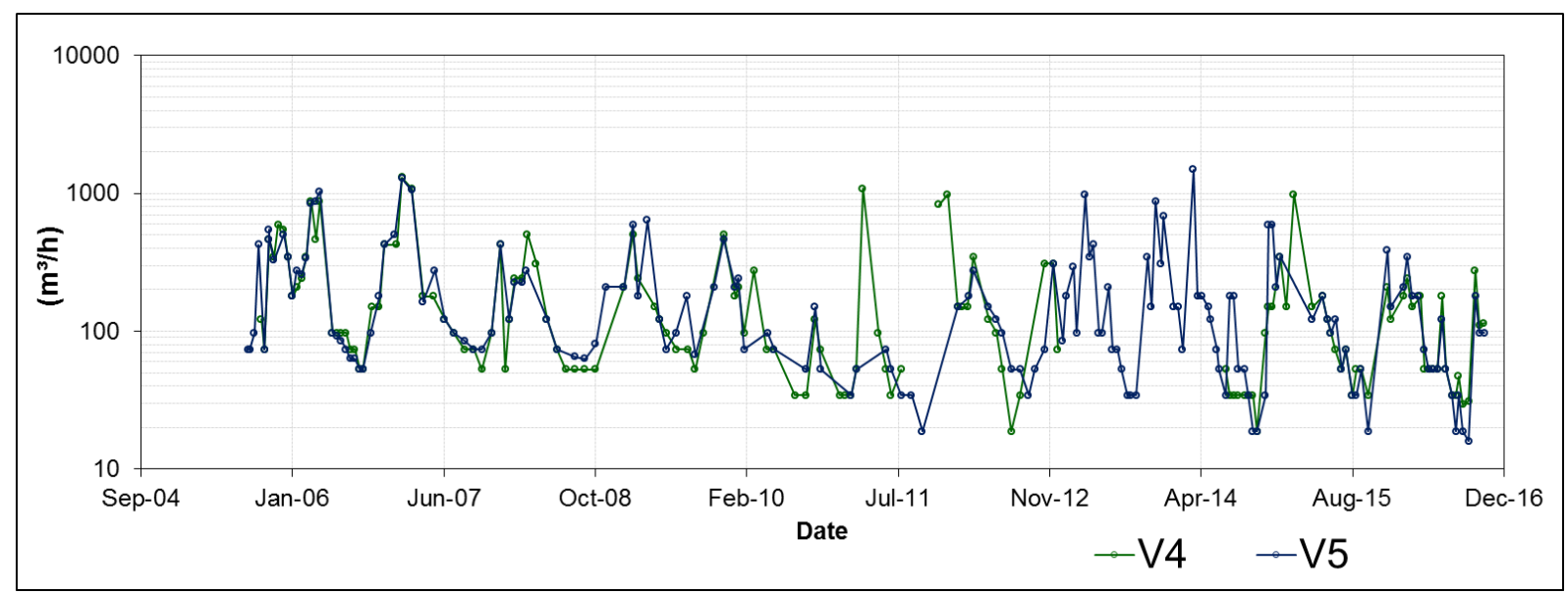

Figure 45- Palmital creek hydrogram based on data from spillways V4 and V5.

Average flow rate in Macaco Barbado creek (Figure 46) is about $69 \mathrm{~m}^{3} / \mathrm{h}$. There is little difference between measured flows on the two spillways, so it is uncertain define if creek is effluent or influent. Minimum flow rates occurs in August when it is about $50 \mathrm{~m}^{3} / \mathrm{h}$. 


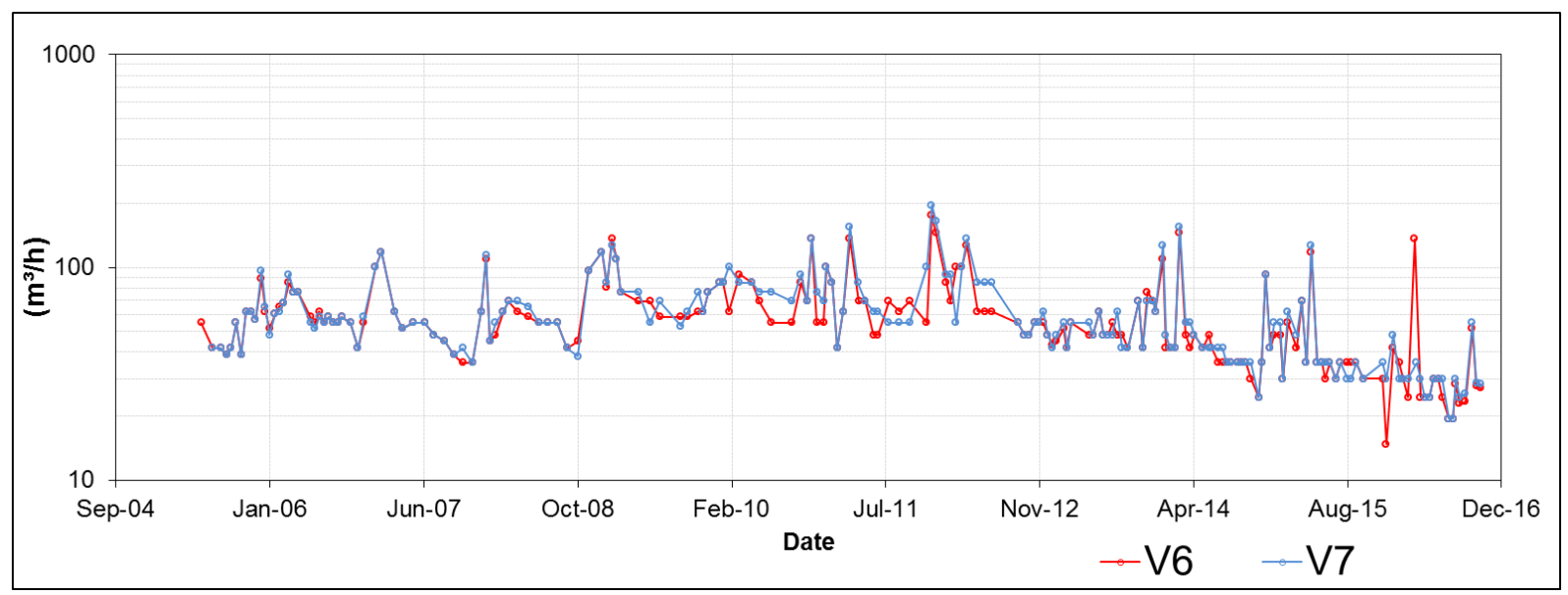

Figure 46- Macaco Barbado creek hydrogram based on data from spillways V6 and V7.

\section{Historical Pumping}

Since 2006 a total of 9 pumping wells were drilled throughout the study area (Figure 47), of which 8 were operated by Samarco ( 5 in Alegria North; and 3 in Alegria South) and one by Vale SA (Alegria North). Pumping flow rate has increased along the years to attend the dewatering requirement (Figure 48). From 2006 to 2008 only PTR_N_01 operate with 110 m³/h pumping rates. In June of 2008 more two (PTR_N_02 and PTR_N_03) pumping wells were installed in Alegria North, that increment $300 \mathrm{~m}^{3} / \mathrm{h}$ of pumping. In 2009 only PTR_N_01 operated due to mine operation interactions. After 2010 new pumping wells were installed to attend the dewatering program. 


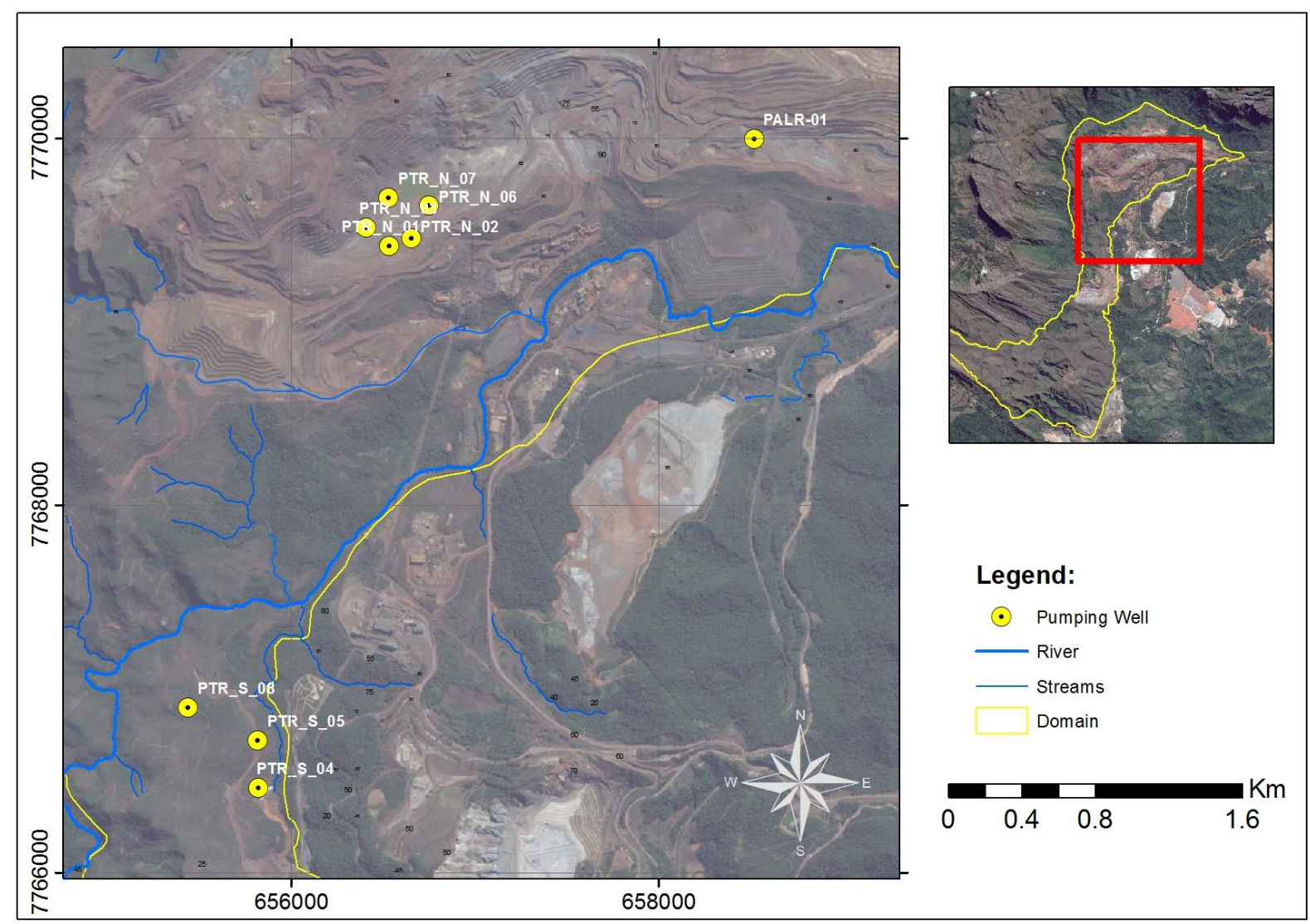

Figure 47- Pumping wells installed in the study area in December 2016

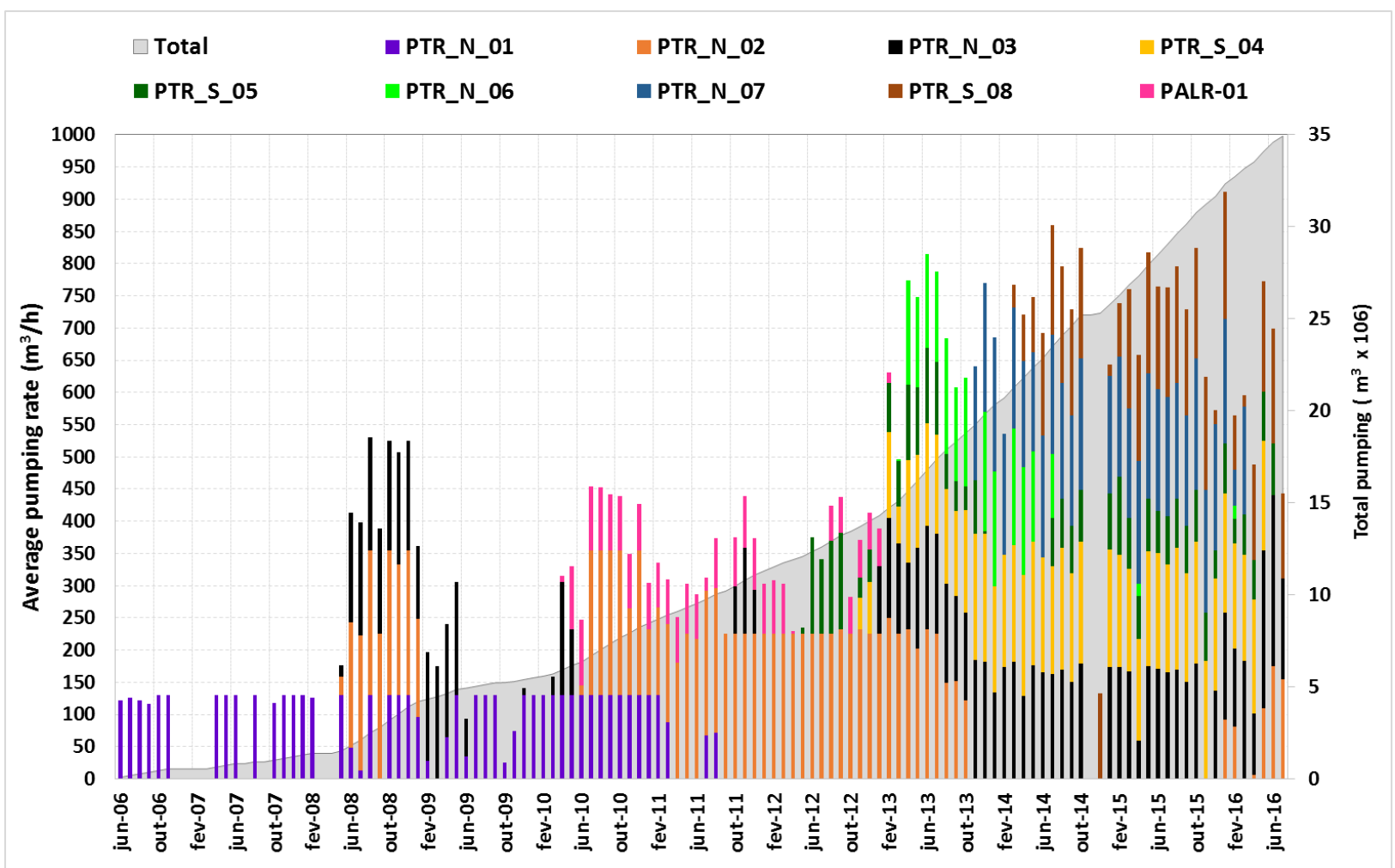

Figure 48- Pumping monitoring since 2006. 


\section{Hydraulic Heads and Groundwater Flow}

Monitoring of groundwater levels has been conducted since 1998 through a network of observation wells (INAs), installed in part to benefit from existing boreholes (Figures 49 and 50). In the area, there are a total of 79 active INAs and 39 inactive ones, destroyed in the course of mining activities. Among the wells, 25 belong to Vale SA and the historical data allowed determining potentiometric level before 2006.

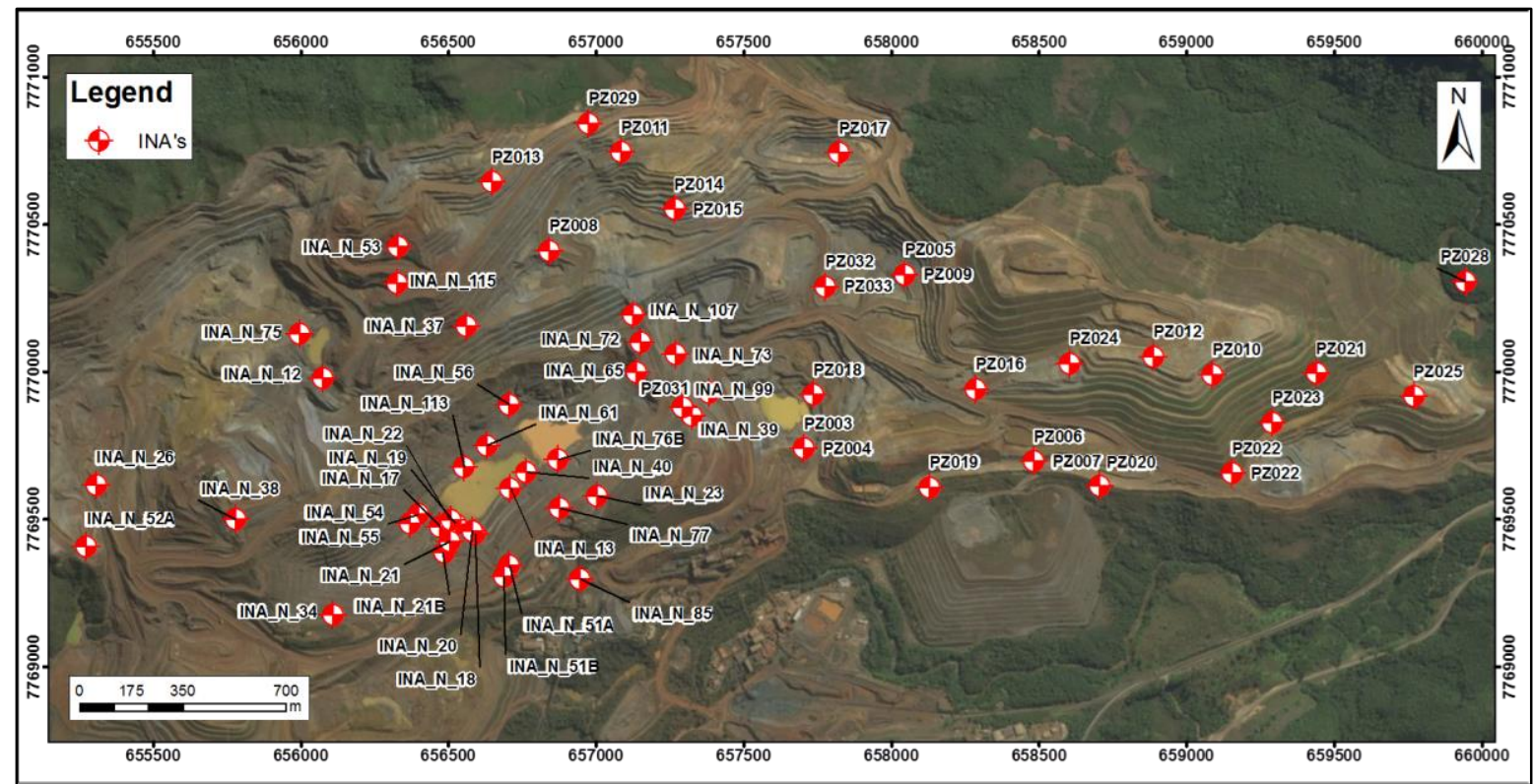

Figure 49 - Location Map of Monitoring Points in Alegria North

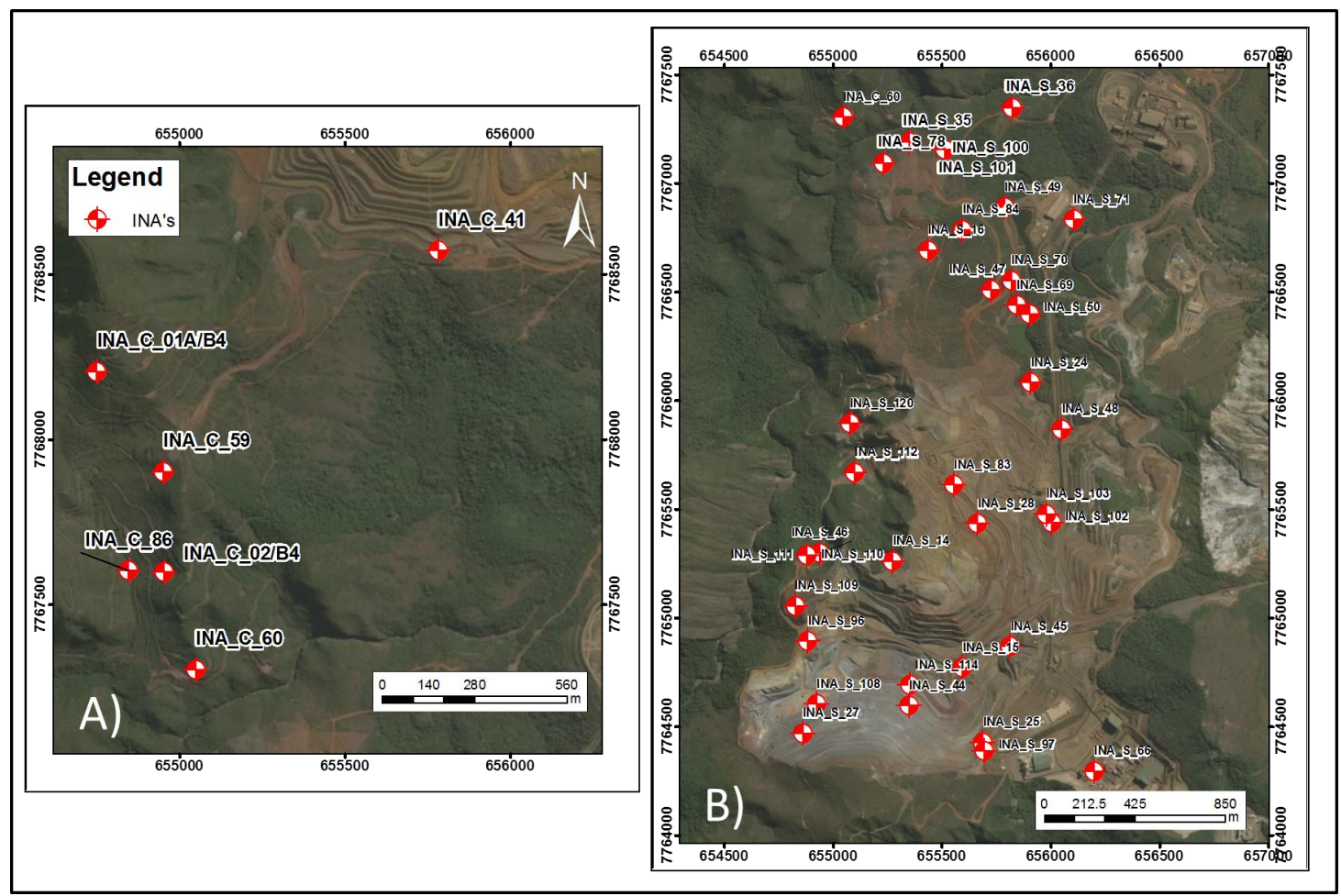

Figure 50 - Location Map of Monitoring Points in (A) Alegria Center and (B) Alegria South 
Figures 51, 52 and 53 show hydraulic head variation over time for Alegria South, Center and North, respectively. As can be seen, there are some data gaps because monitoring wells were destroyed, especially in Alegria North. Vale's observatation wells do not contain a monitoring history.

INAs hydraulic heads from Center and South Alegria normally show a regular pattern; only INA 41 higher values, but always around average of $990 \mathrm{~m}$. After 2013 there is a tendency of drawdown due to the interferences from pumping wells.

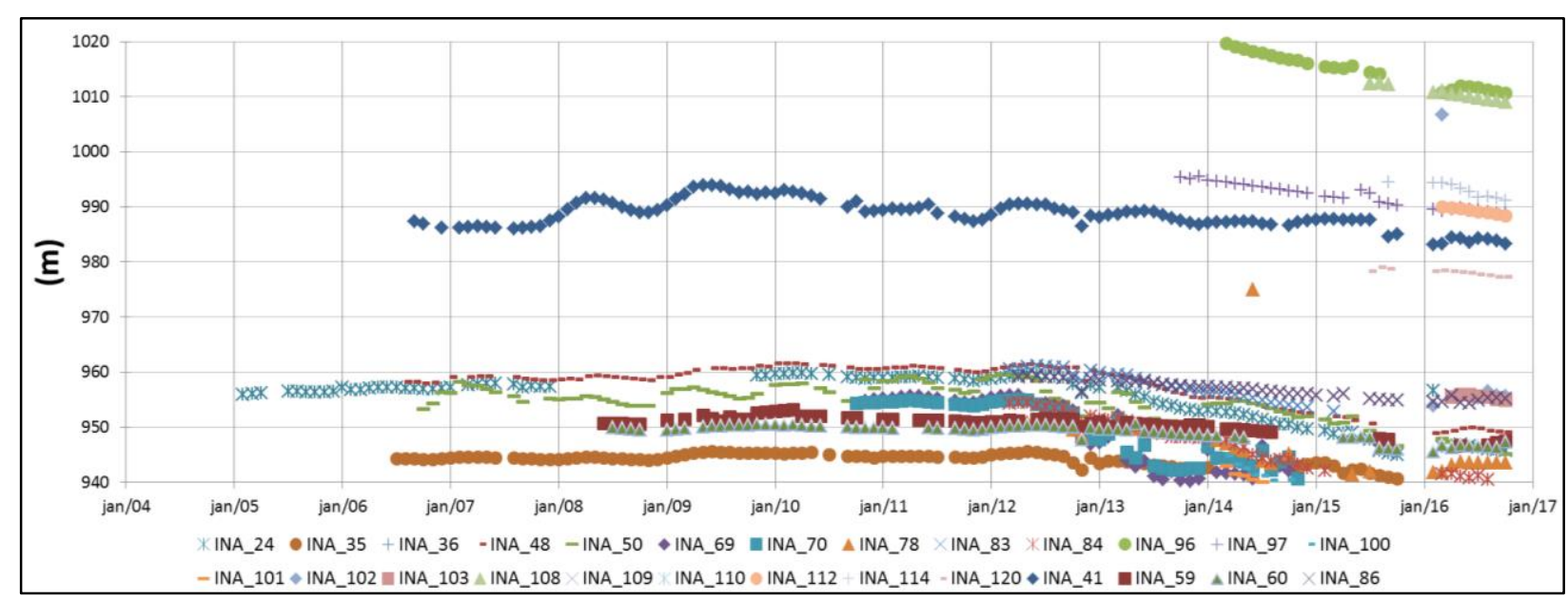

Figure 51- Hydraulic head monitoring for Alegria South

The only region that shows clear, consistent evidence of drawdown is Alegria North. Figures 53 and 54 present hydraulic head variation for Alegria North, but the first one is related to E-SE portion, affected by drawdown, and the second one to N-NW portion, not affected by drawdown.

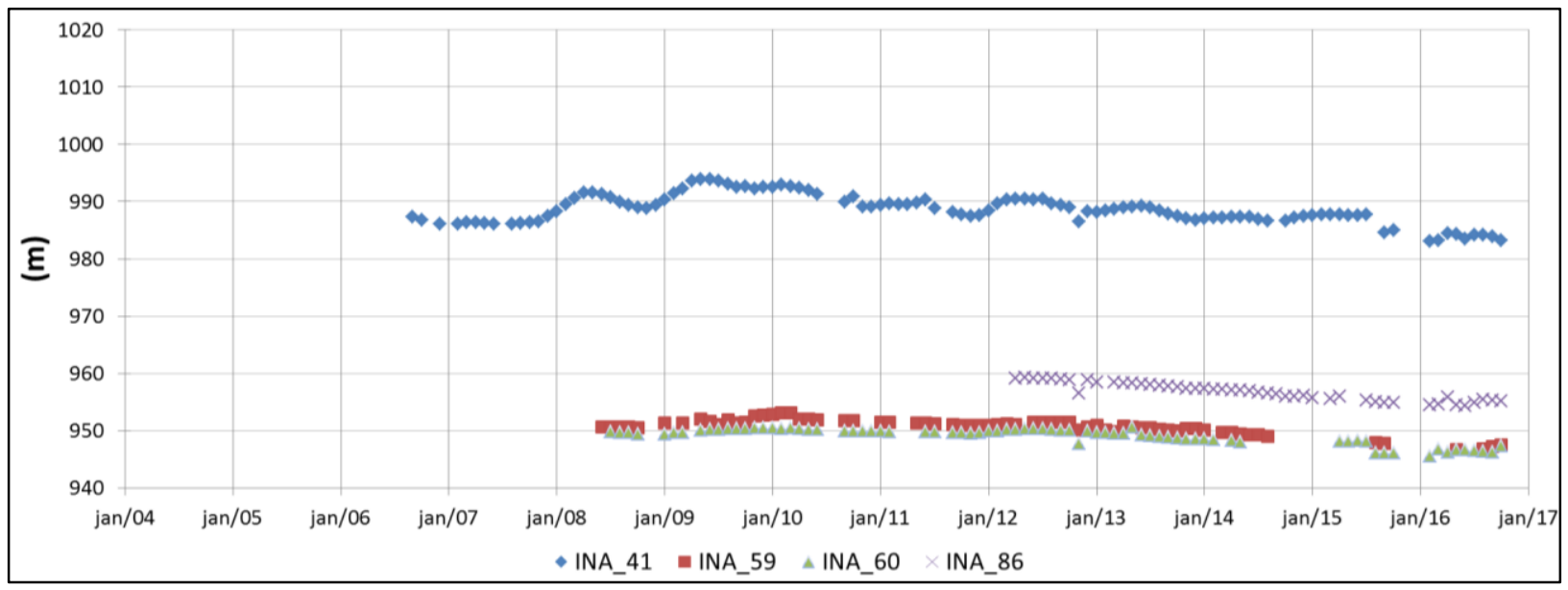

Figure 52 - Hydraulic head monitoring for Alegria Center 
Figure 55 displays the potenciometric and groundwater flow map before pumping stage in 2006. The main flow directions can be observed in the figure below, and show a pattern of discharge into the Piracicaba River.

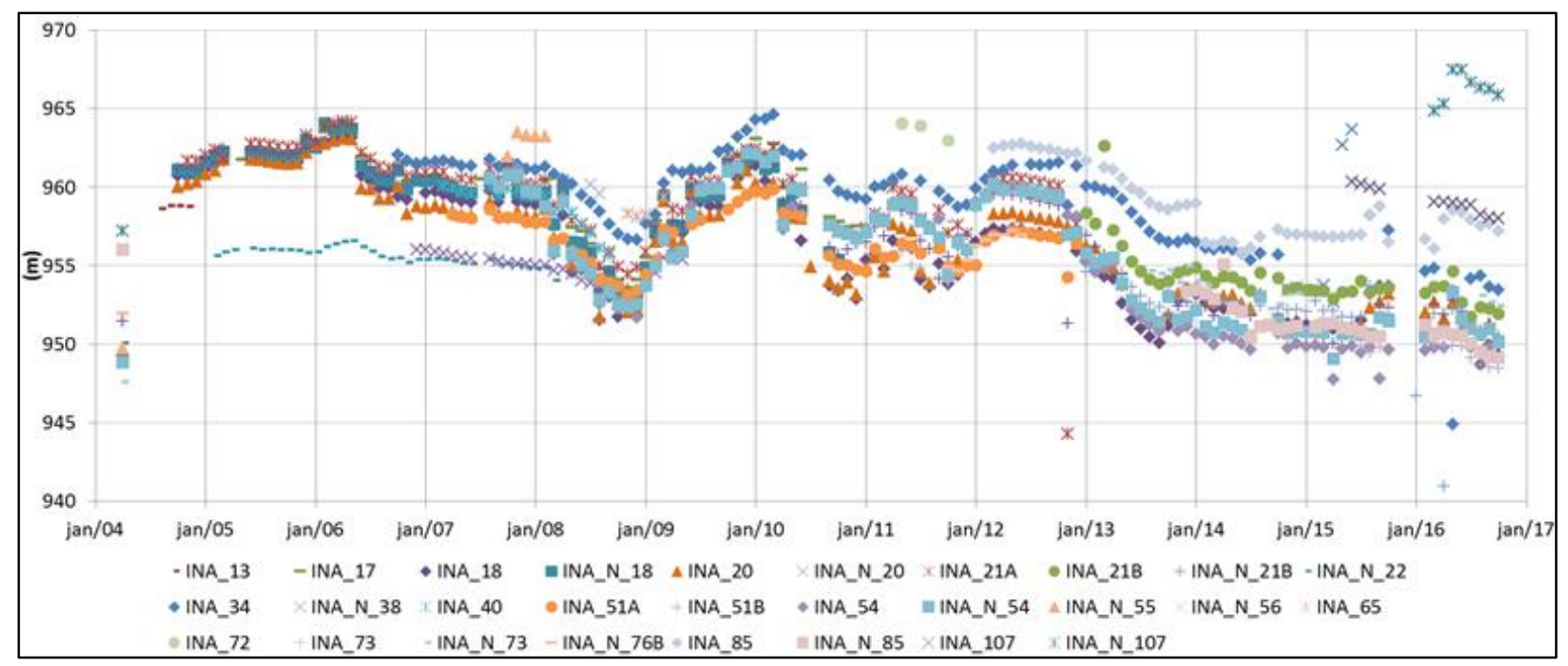

Figure 53 - Hydraulic head monitoring for Alegria North (E-SE portion).

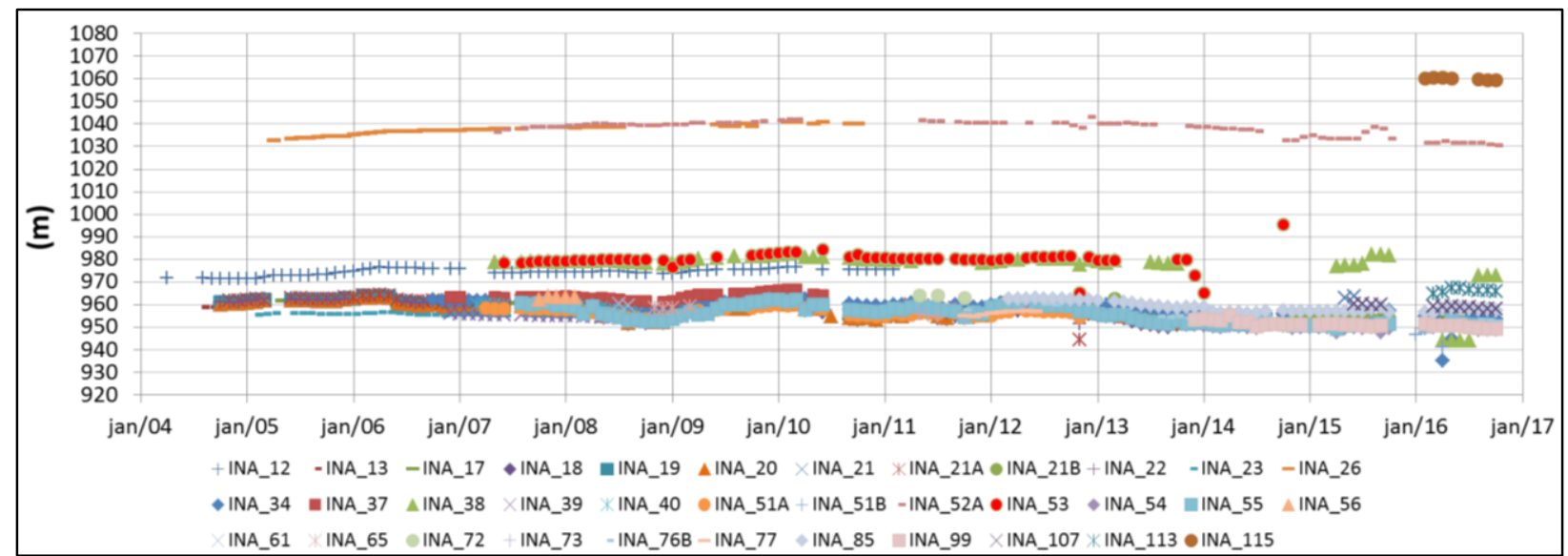

Figure 54 - Hydraulic head monitoring for Alegria North (W-NW portion). 


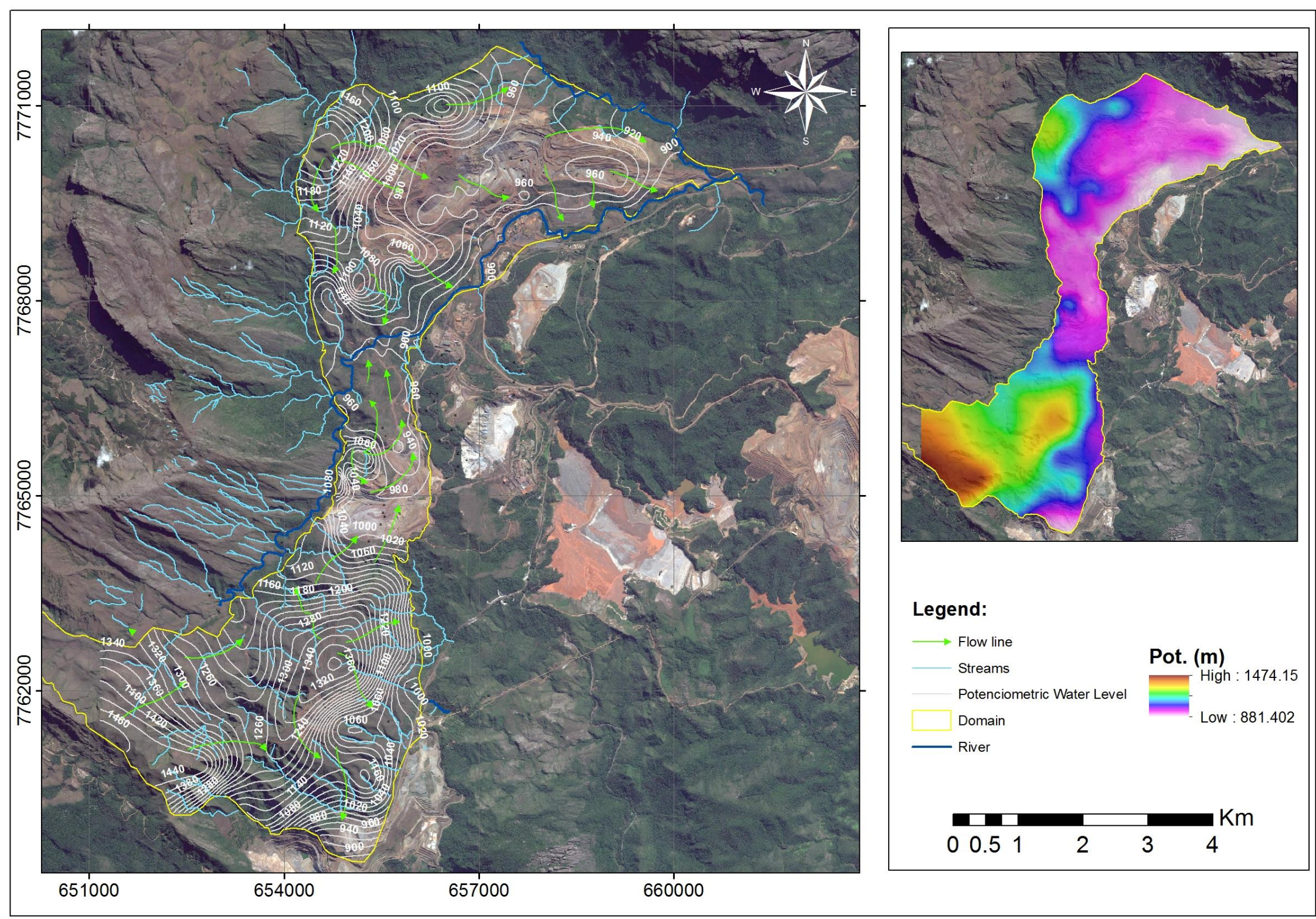

Figure 55 - Equipotencial and flow map in May 2006. 


\section{Hydraulic Paramaters}

Usually aquifer hydraulic parameters can be obtained in field by pumping, slug and bail tests. Pumping tests were conducted in 9 wells installed in Alegria Mine. 41 observation wells (INA) were used to monitor drawdown evolution through space. Results of drawdown versus time were processed in Aquifer Test software to obtain hydraulic conductivity $(K)$ and specific yield (Sy) parameters.

Neumann (1975) was applied to fit data to drawdown curve, due conditions of unconfined aquifer in Alegria Mine. Although the neuman method does not allow anisotropy to be detected, the different pumping tests that influenced the observation wells make it possible to distinguish different $\mathrm{K}$ ratios for the same geological unit. Table 8 presents results for the 9 pumping tests, indicated in different itabirites types. After performing several pumping tests with different observation wells, heterogeneity and anisotropy of porous media can be evaluated arranging the intervals tested. In single-well pumping tests, $\mathrm{K}$ tends to be smaller than using an observe well. If aquifer has only vertical anisotropy, $\mathrm{K}$ value obtained in observation wells tends to be equal to the horizontal one (CUSTODIO \& LLAMAS, 2001).

Table 8 - Hydraulic parameters obtained with pumpins tests.

\begin{tabular}{|c|c|c|c|c|c|c|}
\hline Area & ID & $\begin{array}{c}\begin{array}{c}\text { Hydraulic } \\
\text { Conductivity }\end{array} \\
\mathrm{m} / \mathrm{s}\end{array}$ & Sy & Sy/S & $\begin{array}{l}\text { Pumping well } \\
\text { distance (m) }\end{array}$ & Rock type \\
\hline \multirow{6}{*}{$\begin{array}{l}\text { Pumping Test } \\
\text { (PTR_N_01) }\end{array}$} & INA17 & $1.67 \mathrm{E}-05$ & $5.1 \%$ & $2.13 E+01$ & 87.59 & Martite itab. \\
\hline & INA18 & $2.80 \mathrm{E}-05$ & $9.4 \%$ & $7.52 \mathrm{E}+01$ & 67.47 & Specularite itab. \\
\hline & INA19 & $2.60 \mathrm{E}-05$ & $4.3 \%$ & $2.80 \mathrm{E}+02$ & 67.95 & Specularite itab. \\
\hline & INA20 & $9.52 \mathrm{E}-06$ & $5.5 \%$ & $1.14 \mathrm{E}+01$ & 65.34 & Specularite itab. \\
\hline & INA21 & $2.60 \mathrm{E}-05$ & $12.5 \%$ & $1.00 \mathrm{E}+01$ & 31.22 & Specularite itab. \\
\hline & INA22 & $3.45 \mathrm{E}-05$ & $5.6 \%$ & $2.90 \mathrm{E}+02$ & 85.78 & Specularite itab. \\
\hline \multirow{7}{*}{$\begin{array}{l}\text { Pumping Test } \\
\text { (PTR_N_02) }\end{array}$} & PTR02 & $2.51 \mathrm{E}-06$ & & & & Amphibolite itab \\
\hline & INA17 & $2.75 \mathrm{E}-05$ & $9.9 \%$ & $1.00 \mathrm{E}+01$ & 87.59 & Martite itab. \\
\hline & INA18 & $2.82 \mathrm{E}-05$ & $25.4 \%$ & $1.00 \mathrm{E}+01$ & 67.47 & Specularite itab. \\
\hline & INA19 & 2.84E-05 & $10.0 \%$ & $1.00 \mathrm{E}+01$ & 67.95 & Specularite itab. \\
\hline & INA20 & $1.21 \mathrm{E}-05$ & $4.9 \%$ & $1.13 \mathrm{E}+01$ & 65.34 & Specularite itab. \\
\hline & INA21 & $3.45 \mathrm{E}-05$ & $5.6 \%$ & $1.13 \mathrm{E}+01$ & 31.22 & Specularite itab. \\
\hline & INA22 & $3.45 \mathrm{E}-05$ & $5.5 \%$ & $2.82 \mathrm{E}+01$ & 85.78 & Specularite itab. \\
\hline \multirow{3}{*}{$\begin{array}{l}\text { Pumping Test } \\
\text { (PTR_S_04) }\end{array}$} & PTR04 & $1.28 \mathrm{E}-06$ & & & & Amphibolite itab \\
\hline & INA69 & $2.72 \mathrm{E}-06$ & $10.9 \%$ & $9.86 \mathrm{E}+01$ & 34.07 & Martite itab. \\
\hline & INA70 & $4.04 \mathrm{E}-06$ & $2.7 \%$ & $1.15 \mathrm{E}+02$ & 90.30 & Martite itab. \\
\hline \multirow{4}{*}{$\begin{array}{l}\text { Pumping Test } \\
\text { (PTR_N_03) }\end{array}$} & PTR03 & $1.54 \mathrm{E}-06$ & & & & Specularite itab. \\
\hline & INA54 & $9.72 \mathrm{E}-06$ & $0.3 \%$ & $1.00 \mathrm{E}+02$ & 169.25 & Amphibolite itab \\
\hline & INA55 & $7.76 \mathrm{E}-06$ & $0.4 \%$ & $1.00 \mathrm{E}+02$ & 179.31 & Amphibolite itab \\
\hline & INA19 & $2.99 \mathrm{E}-05$ & $12.0 \%$ & $1.00 \mathrm{E}+02$ & 68.07 & Specularite itab. \\
\hline
\end{tabular}

\begin{tabular}{|c|c|c|c|c|c|c|}
\hline Area & ID & \begin{tabular}{|c|}
$\begin{array}{c}\text { Hydraulic } \\
\text { Conductivity }\end{array}$ \\
$\mathrm{m} / \mathrm{s}$ \\
\end{tabular} & Sy & Sy/S & \begin{tabular}{|c|} 
Pumping \\
well \\
distance $(m)$
\end{tabular} & Rock type \\
\hline \multirow{4}{*}{$\begin{array}{l}\text { Pumping Test } \\
\text { (PTR_N_06) }\end{array}$} & PTR06 & $1.26 \mathrm{E}-06$ & & & & Specularite itab. \\
\hline & INA18 & $1.21 \mathrm{E}-06$ & $7.7 \%$ & $1.00 \mathrm{E}+01$ & 124.87 & Specularite itab. \\
\hline & INA22 & $1.12 \mathrm{E}-05$ & $1.3 \%$ & $1.43 E+01$ & 276.29 & Specularite itab. \\
\hline & INA54 & $1.24 \mathrm{E}-04$ & $0.1 \%$ & $9.96 \mathrm{E}+05$ & 369.55 & Amphibolite itab \\
\hline \multirow{3}{*}{$\begin{array}{c}\text { Pumping Test } \\
\text { (PTR_N_07) }\end{array}$} & $\begin{array}{l}\text { PTR07 } \\
\end{array}$ & $1.80 \mathrm{E}-06$ & & & & Specularite itab. \\
\hline & PTR03 & $1.72 \mathrm{E}-07$ & $16.8 \%$ & $2.08 \mathrm{E}+02$ & 202.84 & Specularite itab. \\
\hline & INA55 & $9.64 \mathrm{E}-06$ & $2.1 \%$ & $1.33 \mathrm{E}+01$ & 248.58 & Amphibolite itab \\
\hline $\begin{array}{l}\text { Pumping Test } \\
\text { (PTR_S_08) }\end{array}$ & PTR08 & $1.93 \mathrm{E}-05$ & & & & Amphibolite itab \\
\hline \multirow{2}{*}{$\begin{array}{c}\text { Pumping Test } \\
\text { Vale Fabrica } \\
\text { Nova }\end{array}$} & PFNO2 & $1.44 \mathrm{E}-06$ & & & & itabirite \\
\hline & PZSS05 & $2.23 \mathrm{E}-06$ & $13.8 \%$ & $5.23 E+01$ & 24.65 & itabirite \\
\hline \multirow{11}{*}{$\begin{array}{c}\text { Pumping Test } \\
\text { Vale } \\
\text { Timbopeba }\end{array}$} & Poço01 & $3.17 \mathrm{E}-07$ & & & & itabirite \\
\hline & Poço03 & $1.11 \mathrm{E}-06$ & & & & itabirite \\
\hline & Poço04 & $1.10 \mathrm{E}-06$ & & & & itabirite \\
\hline & Poço05 & $4.59 \mathrm{E}-06$ & & & & itabirite \\
\hline & Poço06 & $1.23 \mathrm{E}-06$ & & & & itabirite \\
\hline & Poço07 & $4.70 \mathrm{E}-06$ & & & & itabirite \\
\hline & Poço08 & $1.94 \mathrm{E}-06$ & & & & itabirite \\
\hline & Poço10 & $3.87 \mathrm{E}-06$ & & & & itabirite \\
\hline & Poço11 & $2.42 \mathrm{E}-06$ & & & & itabirite \\
\hline & Poço12 & $8.57 \mathrm{E}-06$ & & & & itabirite \\
\hline & Poço13 & $4.25 \mathrm{E}-06$ & & & & itabirite \\
\hline
\end{tabular}

In addition, slug and recovery tests were conducted throughout the area to corroborate the pumping test results (Table 9). The slug tests were done in observation wells using a pression transductor and a tube to make a abrut change in groundwater level. Recovery tests were done after each pumping test. 
Table 9 - Hydraulic parameters obtained with slug and recovery tests.

\begin{tabular}{|c|c|c|c|}
\hline \multirow{2}{*}{ Aquifer test } & \multirow{2}{*}{ Id } & $\begin{array}{c}\text { Hydraulic } \\
\text { Conductivity }\end{array}$ & \multirow{2}{*}{ Rock type } \\
\cline { 3 - 3 } & & $\mathrm{m} / \mathbf{s}$ & \\
\hline Slug Test & INA18 & $2.48 \mathrm{E}-07$ & IE \\
\hline Slug Test & INA20 & $1.51 \mathrm{E}-07$ & IE \\
\hline Slug Test & INA21 & $1.47 \mathrm{E}-06$ & IE \\
\hline Slug Test & INA24 & $1.20 \mathrm{E}-07$ & IE \\
\hline Slug Test & INA30 & $1.78 \mathrm{E}-07$ & IE \\
\hline Slug Test & INA34 & $9.71 \mathrm{E}-06$ & IE \\
\hline Slug Test & INA36 & $3.89 \mathrm{E}-07$ & IA \\
\hline Slug Test & INA51 & $2.88 \mathrm{E}-07$ & IA \\
\hline Slug Test & INA54 & $5.25 E-07$ & IA \\
\hline Slug Test & INA58 & $6.46 E-06$ & IE \\
\hline Slug Test & INA64 & $1.17 E-07$ & IE \\
\hline Slug Test & INA77 & $2.63 E-06$ & IM \\
\hline Slug Test & INA78 & $1.25 E-07$ & IM \\
\hline Slug Test & INA84 & $6.46 E-08$ & IA \\
\hline Slug Test & INA86 & $2.40 E-07$ & IM \\
\hline Slug Test & INA51 & $1.38 E-06$ & IA \\
\hline Slug Test & INA64 & $6.28 E-07$ & IE \\
\hline Slug Test & INA67 & $1.07 E-07$ & IE \\
\hline Slug Test & INA58 & $5.76 E-07$ & IE \\
\hline Slug Test & INA96 & $8.65 E-08$ & Phyllite \\
\hline & & & \\
\hline
\end{tabular}

\begin{tabular}{|c|c|c|c|}
\hline \multirow{2}{*}{ Aquifer test } & \multirow{2}{*}{ Id } & $\begin{array}{c}\text { Hydraulic } \\
\text { Conductivity }\end{array}$ & \multirow{2}{*}{ Rock type } \\
\cline { 3 - 3 } & & $\mathrm{m} / \mathrm{s}$ & \\
\hline Slug Test & INA59 & $2.00 \mathrm{E}-04$ & IM \\
\hline Slug Test & INA60 & $2.87 \mathrm{E}-06$ & IM \\
\hline Slug Test & INA62 & $3.78 \mathrm{E}-07$ & IE \\
\hline Bail Test & PTR01 & $2.04 \mathrm{E}-06$ & IM \\
\hline Bail Test & PTR02 & $1.32 \mathrm{E}-06$ & IE \\
\hline Bail Test & PTR03 & $4.55 \mathrm{E}-06$ & IE \\
\hline Bail Test & PTR04 & $4.86 \mathrm{E}-06$ & IA \\
\hline Bail Test & PTR06 & $5.14 \mathrm{E}-06$ & IE \\
\hline Bail Test & PTR07 & $4.91 \mathrm{E}-06$ & IE \\
\hline Bail Test & PTR08 & $7.25 \mathrm{E}-06$ & IA \\
\hline Bail Test & Poç004 & $4.88 \mathrm{E}-06$ & itabirite \\
\hline Bail Test & Poç005 & $1.75 \mathrm{E}-05$ & itabirite \\
\hline Bail Test & Poço06 & $2.14 \mathrm{E}-04$ & itabirite \\
\hline Bail Test & Poço07 & $5.50 \mathrm{E}-07$ & itabirite \\
\hline Bail Test & Poço08 & $1.09 \mathrm{E}-05$ & itabirite \\
\hline Bail Test & Poç010 & $6.73 \mathrm{E}-06$ & itabirite \\
\hline Bail Test & Poço11 & $1.34 \mathrm{E}-05$ & itabirite \\
\hline Bail Test & Poç012 & $1.26 \mathrm{E}-05$ & itabirite \\
\hline Bail Test & Poç013 & $6.98 \mathrm{E}-06$ & itabirite \\
\hline
\end{tabular}

Figure 56 presents data processed in box plot graphs considering the different itabirite types. Hydraulic conductivity geometric mean for all itabirites is $4.42 \cdot 10^{-6} \mathrm{~m} / \mathrm{s}$. Specularite itabirite (IE) hydraulic conductivity range is large and mean value is $4.55 \cdot 10^{-6} \mathrm{~m} / \mathrm{s}$, very close to geometric mean. IA and IM hydraulic conductivity values are $2.8 \cdot 10^{-6} \mathrm{~m} / \mathrm{s}$ and $3.69 \cdot 10^{-6} \mathrm{~m} / \mathrm{s}$, respectively. IE specific yield value is about $9.8 \%$ and IE is $6 \%$, which result was expected due the strong schistosity foliation of IE. IA specific yield has a large range due to few tests performed and the weathering material characteristics.

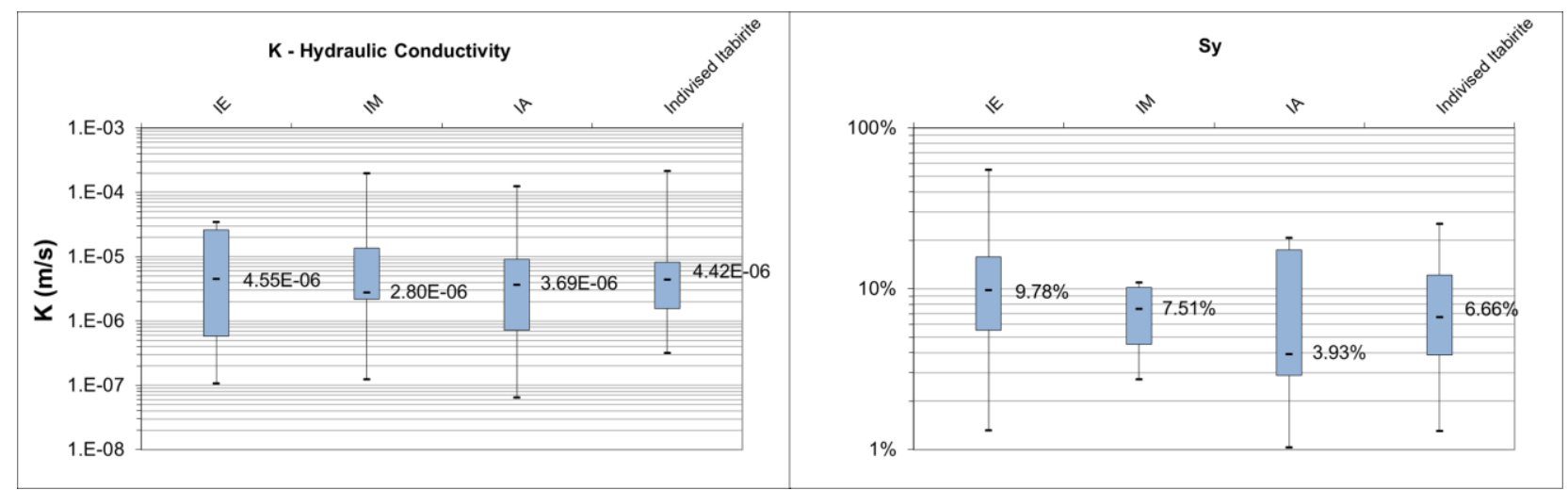

Figure 56 - Hydraulic Parameter: specularite itabirite IE), Martite itabirite (IM), Amphibolitic itabirite (IA) and indivised itabirite

\section{Water Balance}

Calculations of water balance intend to equalize inflows and outflows in a river catchment, assuming steady-state conditions. Steady-state conditions consider a closed basin, with no lateral 
groundwater inflow or outflow. Results of water balance for the study area are presented in Table 10.

Assuming an average runoff coefficient to sub-catchment of $75 \mathrm{~m}^{3} / \mathrm{h} / \mathrm{km}^{2}$ and an evaporation rate of $822 \mathrm{~mm} /$ year, a recharge estimation of $31 \%$ from average annual precipitation is obtained. Under these conditions, groundwater flow within Piracicaba River sub-catchment would be $4,345 \mathrm{~m}^{3} / \mathrm{h}$.

This volume represents the renewable water resource, that is, the volume of groundwater that theoretically can be abstracted without reducing the volume of water available in aquifer permanent storage.

Table 10 - Water Balance for the study area.

\begin{tabular}{|c|c|c|c|}
\hline Components & \multirow{2}{*}{$\mathrm{mm} /$ year } & \multirow{2}{*}{$\mathrm{m}^{3} / \mathbf{h}$} & \multirow{2}{*}{$\% A A P^{b}$} \\
\hline INFLOW & & & \\
\hline Precipitation ${ }^{\mathrm{ab}}$ & 2,189 & 14,283 & 100 \\
\hline Lateral Inflow & 0 & 0 & \\
\hline Total & 2,189 & 14,283 & 100 \\
\hline \multicolumn{4}{|l|}{ OUTFLOW } \\
\hline Runoff & 653 & 4,400 & 31 \\
\hline Evapotranspiration ${ }^{c}$ & 822 & 5,538 & 38 \\
\hline Recharge & 714 & 4,345 & 31 \\
\hline Pumping & 0 & 0 & \\
\hline Lateral Outflow & 0 & 0 & \\
\hline TOTAL & 2,189 & 14,283 & 100 \\
\hline
\end{tabular}

a) Area of Piracicaba River sub-basin: $59 \mathrm{~km}^{2}$

b) $\mathrm{AAP}=$ Annual Average Precipitation

c) Value estimated from the data available (precipitation and evaporation)

\section{Conceptual Model Synthesis}

This topic provides a synthesis of all information collected and interpreted for construction of a hydrogeological conceptual model for study area based essentially on existing hydroestratigraphical units, hydraulic heads distribution and groundwater flow direction (groundwater flow net), recharge and discharge areas and groundwater abstraction (Figure 55).

In Caue aquifer, lithotypes found in study area were grouped in three hydroestratigraphic units: Upper Aquifer, Intermediate Aquifer and Lower Aquifer. Upper Aquifer, located in the central and southern portions of Alegria Mine, corresponds to the part of Cauê composed by shear zones, 
marked by the penetrative foliation of the specularite itabirite (IE) with hydraulic conductivity values up to $10^{-5} \mathrm{~m} / \mathrm{s}$. Intermediate aquifer occurs in regions with the highest predominance of martitic itabirite with hydraulic conductivity values in average of $10^{-6} \mathrm{~m} / \mathrm{s}$. Lower Aquifer, located mainly in east part of Alegria Mine, consists by anfibolitic itabirites with hydraulic conductivity varing betwenn $10^{-6} \mathrm{~m} / \mathrm{s}$ and $10^{-7} \mathrm{~m} / \mathrm{s}$.

Quartzites and phylites from Batatal Formation (W and N areas) and schists and phyllites from Piracicaba Group (E area) were considered aquitards, with hydraulic conductivity values around $10^{-8} \mathrm{~m} / \mathrm{s}$ or less. Phyllites from Batatal Formation were defined as aquiclude, with hydraulic conductivity around $10^{-8} \mathrm{~m} / \mathrm{s}$ (MOURÃO, 2007). These low permeability units concentrate groundwater flow through itabirites (Cauê Aquifer) and are responsible for the occurrence of many springs in contact areas with itabirites and in upstream portion of Piracicaba's tributaries. This condition reflects hydraulic gradients more pronounced in higher topographic portions and smoother in itabiritic zones.

There are other discrete geological features, which locally affect groundwater flow (i.e. metabasic dykes, geological structures) with hydraulic conductivity around $10^{-8} \mathrm{~m} / \mathrm{s}$ or less. An effect of this interference is observed in the west portion of North Alegria (near INA52), where a reverse fault has been interpreted in an area showing steeper hydraulic gradient.

Correlation between potenciometric map and mapped geological structures indicates that some of them have direct influence in groundwater flow system. In the southern part, Piracicaba River flows over quartzites and phyllites from Caraça Group and have no connection with Cauê Aquifer (Figure 56). Part of groundwater flow is driven to southern region, outside model domain, and the other part to the north, where seems to be a groundwater divisor (Figure 57). This divisor corresponds to an effective recharge zone, from where groundwater flows towards Alegria South, discharging in Piracicaba river

In Alegria North, groundwater flow is controlled by the different hydrostratigraphical units. Some impermeable rocks, like phyllites and intrusive rocks, control groundwater flow and increase hydraulic gradient with heads from 1,080 to $960 \mathrm{~m}$. Hydraulic gradient is around $3 \%$ reaching $10 \%$ in the west area of Alegria North. Deep flow occurs from NW to SE region, where it intercepts the main discharge zone, Piracicaba River (Figure 58).

According to the hydrograms analyses and water balance, effective recharge was $31 \%$ of precipitation along the Piracicaba River sub-basin. Presence of high hydraulic gradients in area is governed by topography, recharge zones and hydraulic conductivities contrast among hydroestratigraphic units in Alegria Mine (Figure 59). 


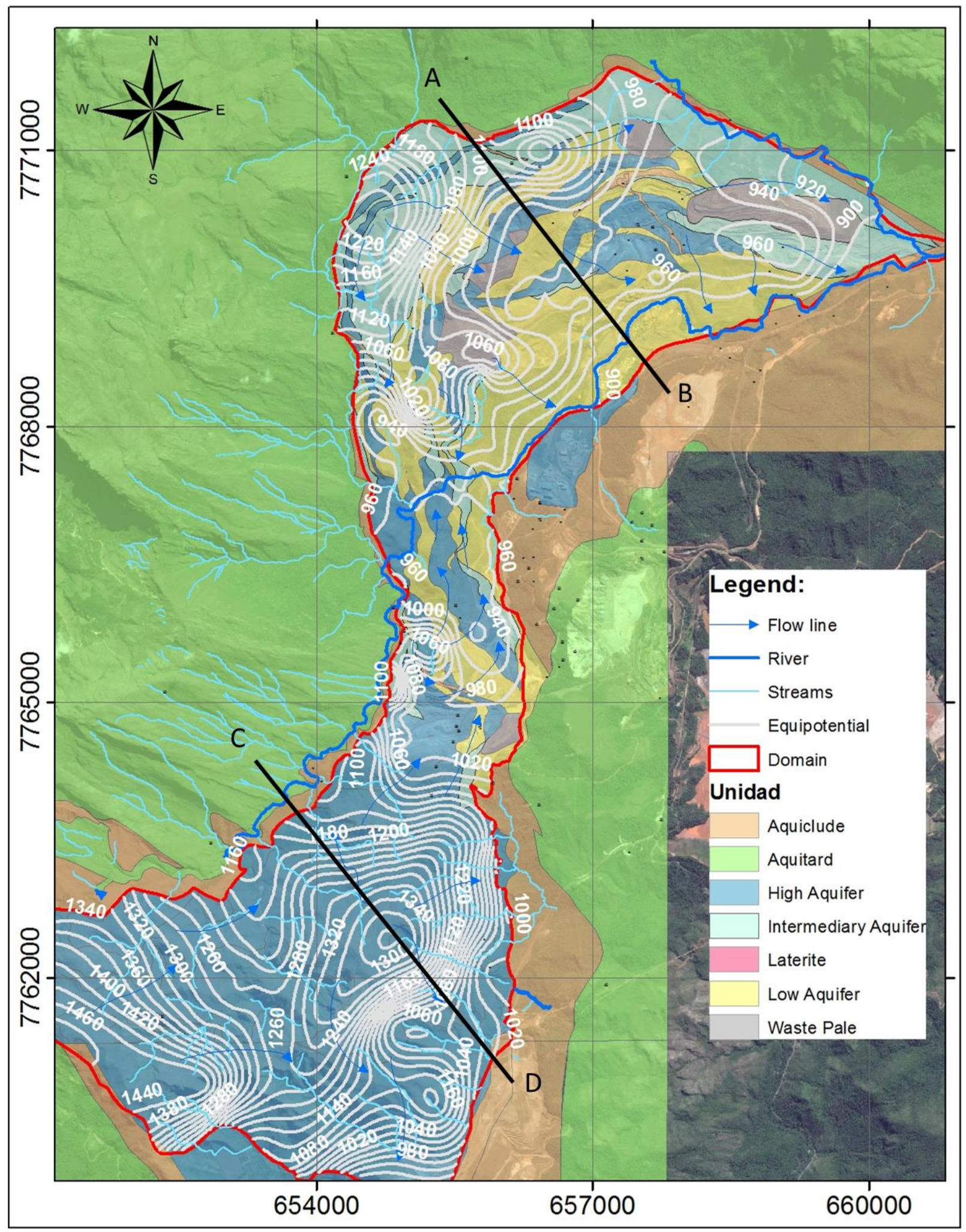

Figure 57 - Hydroestratigraphic units and the flow direction 


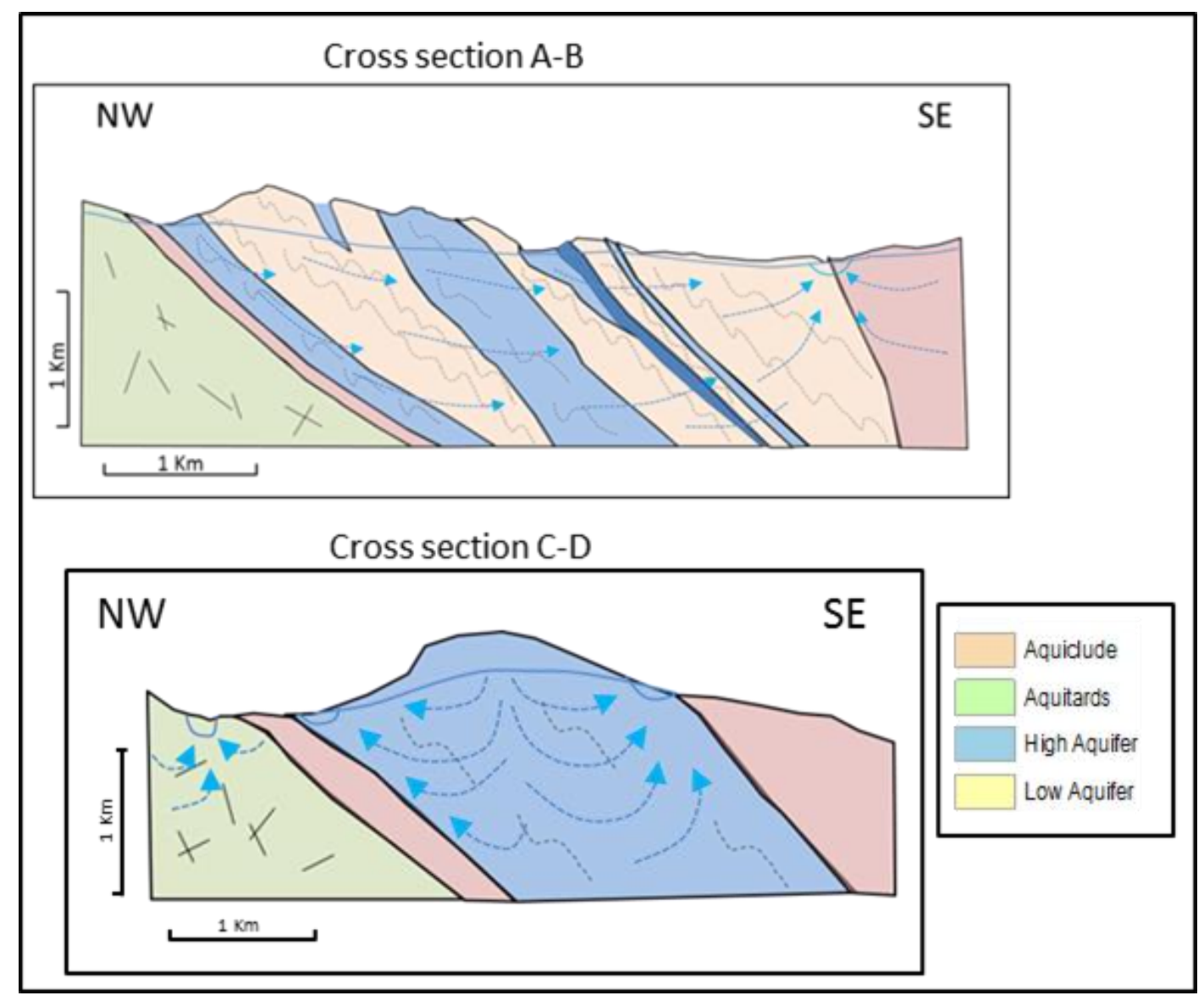

Figure 58 - Sections A-B and C-D showing groundwater flow towards discharge zone in Piracicaba River

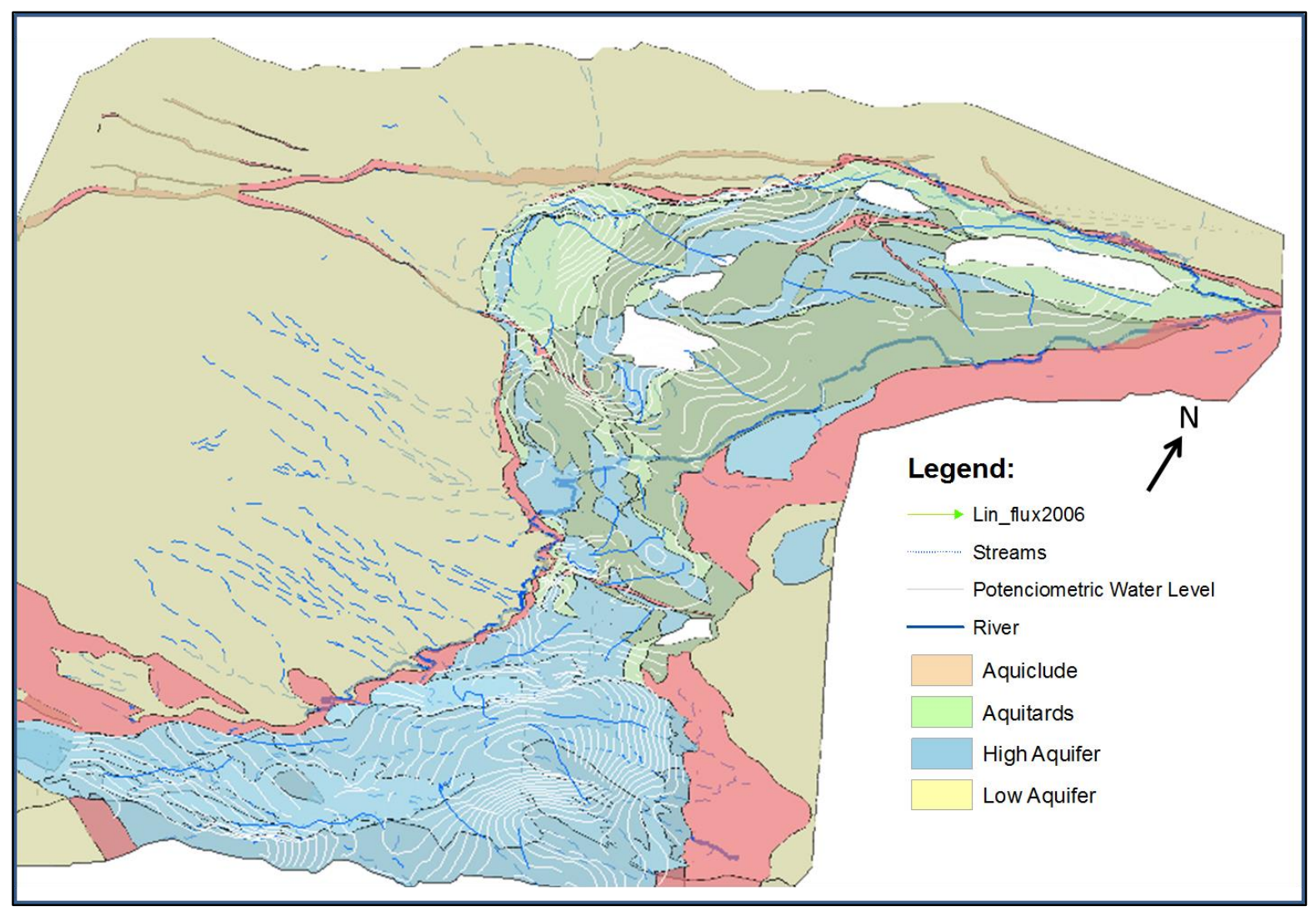

Figure 59- 3D hydroestratigraphic model for Alegria Mine 


\section{Conclusions}

Surrounded by low permeability rocks from Batatal Formation and Piracicaba Group with hydraulic conductivities around $10^{-8} \mathrm{~m} / \mathrm{s}$, itabirites constitute the main regional groundwater reservoir, Cauê Aquifer, where hydraulic conductivity ranges between $10^{-5}$ and $10^{-7} \mathrm{~m} / \mathrm{s}$.

Potenciometric map shows that hydraulic head varies from $1,020 \mathrm{~m}$ at the NW limit of North Alegria to $915 \mathrm{~m}$ close to the confluence between Piracicaba river and Almas creek.

Water level follows roughly the topography with an eastbound flow. This way, the main groundwater flow vectors follow the surface drainage pattern established by Piracicaba river, which represents a discharge zone for groundwater. Hydraulic gradient is around $3 \%$ reaching $10 \%$ in the west area of Alegria North. In general, hydraulic gradient is varied, a further indicator of abrupt change of hydraulic conductivity of the rock mass. Additionally, there are some intrusives rocks and phyllites features which locally affect groundwater flow.

In aquifers with layers plunging in a given direction, hydraulic conductivity paralel to layer will always be greater than the orthogonal one. Some values of Sy indicate that there is a confinement or semi confinement of aquifer, which is typical of Cauê Aquifer, caused by metamorphic banding, with more and less permeable rock alternation.

\section{Acknowledgements}

This work was funded by Samarco Mineração SA. Special thanks go to Samarco's Hydrogeology team.

\section{References}

Alkmin, F.F.; Marshak, S., 1998: Transamazonian Orogeny in the Southern São Francisco Craton Region, Minas Gerais, Brazil: evidence for Paleoproterozoic collision and collapse in the Quadrilátero Ferrífero. Precambrian Research, v. 90, p.29-58.

Almeira, F.F.M. , 1977, O Cráton do São Francisco. Revista Brasileira de Geociências. São Paulo, $7(4): 349-364$

Beato, D.A.C.; Monsores, A.L.M.; Bertachini, A. C. Hidrogeologia. In: Projeto APA Sul RMBH Estudos do Meio Físico: área de proteção ambiental da região metropolitana de Belo Horizonte. Belo Horizonte: CPRM/SEMAD/CEMIG, 2005.v.9. Parte A.

Custódio, E., Llamas, M.R., 2001. Hidrologia Subterrânea. 2ed. Barcelona: Omega. p. 274.

Dorr, J.V.N. Physiographic, 1969, Stratigraphic and Structural Development of the Quadrilátero Ferrífero. Minas Gerais, Brazil. U.S. Geological Survey,Washington, 641-A, p.A1-A103.

Geoestrutural, 2014. Inventário de Nascentes na Mina de Alegria, Mina de Alegria, Mariana, Minas gerais. Relatório interno da Samarco, p.87

MDGEO, 2008. Inventário de nascentes da região do Conta História. Relatório interno da Vale. 
Maxwell, C.H. 1972. Geology and ore deposits of the Alegria Distric, Minas Gerais, Brazil.

Mourão, M.A.A, 2007: Caracterização hidrogeológica do aquífero Cauê, 297 f., Tese (Doutorado) Universidade Federal de Minas Gerais, Belo Horizonte.

Neuman, S.P., 1975 - Analysis of pumping test data from anisotropic unconfined aquifers considering delayed gravity response. Water Resource., 11 pags: 329-342.

Silva, A. B. da; Sobreiro NETO, A. F.; Bertachini, A. C. Potencial das águas subterrâneas no Quadrilátero Ferrifero. In: CONG. BRAS. de AGUAS SUBTERRÂNEAS, 8, Recife, 1994. Anais... Recife: ABAS/DNPM/CPRM, 1994. p.264-283. 

BRAZIL

João Paulo Chiste-Costa, Alexandra Vieira Suhogusoff, Luiz Carlos Ferrari

Abstract

Groundwater modeling application as a tool for water resources management has been highlighted by the predictive capacity of different scenarios in aquifer systems, becoming a valuable source of information to support dewatering programs. Alegria Mine, located at the east part of Quadrilátero Ferrífero, Minas Gerais State (Brazil), is an example of mining enterprise that will need to drawdown groundwater, in a gradual manner over hyphotetical mine planning sequence in order to extract iron ore reserves. In this context, this paper presents the numerical groundwater flow model of Alegria Mine as well as dewatering simulations performed from 2017 to 2042 to determine number and location of pumping wells, abstraction flow rates, and eventual hydraulic impacts on surface drainage. Simulations indicated installation of 96 pumping wells to exploit a total of $11,400 \mathrm{~m}^{3} / \mathrm{h}$ of groundwater to acess the ore reserve below the water table. Although numeric simulation of dewatering indicates that it is difficult to create drawdown in a short time, groundwater numeric model applied to dewatering is a strong tool to plan a predewatering system. The numerical simulation also can evaluate the cut-off application method along the Piracicaba River to predict its capacity to decrease river leakage to aquifer under dewatering system.

\section{Introduction}

This paper contains the results of dewatering simulations from the hydrogeological numerical model in permanent and transient flow stages of Alegria Mine, situated at east part of Quadrilátero Ferrífero, Minas Gerais State (Brazil). The basis used to support numerical groundwater flow model corresponded to the conceptual model developed by Chiste-Costa et al. (in preparation, Chapter 6).

Numerical modeling involved input of all elements raised by hydrogeological conceptual model, including area hydroestratigraphic units, geological structures, aquifer hydraulic parameters, recharge and discharge conditioners, and topographic conformation of the terrain. Numerical model construction, once finished, undergoes a calibration procedure to fit hydraulic heads calculated by the model to those measured in field monitoring, based on input parameters changing (hydraulic conductivity, specific yield, recharge and evapotranspiration, river/streams aspects). Once calibrated and sensibillity analysis carried out, the numerical model is intended to 
make predictions regarding mine dewatering scenarios for a hypotethical dewatering plan to iron ore reserves in Alegria Mine.

\section{Numerical model description}

Computational numerical groundwater modeling of Alegria Mine and surrounding areas was developed using Visual Modflow software (GUIGER \& THOMAS, 1998). This tool simulates groundwater flow in a 3D geometric configuration, through a numerical finite differences model that solves the following equations developed for transient satured flow (Equation 1) and SteadyState Satured Flow (Equation 2) aquifers (FREEZE \& CHERRY, 1969):

$$
\begin{aligned}
& \frac{\partial}{\partial x}\left(K_{x} \frac{\partial h}{\partial x}\right)+\frac{\partial}{\partial y}\left(K_{y} \frac{\partial h}{\partial y}\right)+\frac{\partial}{\partial z}\left(K_{z} \frac{\partial h}{\partial z}\right)+W=-S_{S} \frac{\partial h}{\partial t} \\
& \frac{\partial}{\partial x}\left(K_{x} \frac{\partial h}{\partial x}\right)+\frac{\partial}{\partial y}\left(K_{y} \frac{\partial h}{\partial y}\right)+\frac{\partial}{\partial z}\left(K_{z} \frac{\partial h}{\partial z}\right)+W=0
\end{aligned}
$$

Equation 1

Equation 2

where $\mathrm{K}_{\mathrm{x}}, \mathrm{K}_{\mathrm{y}}$ and $\mathrm{K}_{\mathrm{z}}$ are hydraulic conductivity in $\mathrm{x}, \mathrm{y}$ and $\mathrm{z}$ directions; $\mathrm{h}=$ hydraulic head; $\mathrm{W}=$ inflow or outflow per volume; $S_{s}=$ specific storage and $t=$ time.

Solutions for the equations can be obtained through several numerical methods, one of them is the finite difference method, used in Modflow application. This approximation implies replacing the continuous system, described in equations, by a finite set of points discretized in space and time. Partial derivatives are replaced by aproximations from the differences in hydraulic head values, using initial and boundary conditions. With this code it is possible to simulate a large variety of geological and hydrogeological situations in three-dimensions. Modflow is the most used and accepted software by environmental agencies and government institutions around the world. Despite its limitations, in special geological structures representation, this software is adequate to regional studies related to water drawdown and water supply, which are the scope of this study.

Modflow is composed of several sets of independent subroutines, called modules, which accommodate the various hydrological components and system boundary conditions, such as rivers, streams, drains, wells, recharge and evapotranspiration rates and discharge zones. Modules division allows independent evaluation of each element considered by the conceptual hydrogeological model.

To enable dewatering simulations, numerical groundwater model of Alegria Mine was calibrated in steady and transient states. Steady-state model was calibrated based on observation wells monitoring data for a time before pumping had started in June 2006. Afterwards, data from pumping and observed wells were used to build a transient model from 2006 to 2016 for several 
periods of stress. Based on calibrated transient model, simulations in transient state were generated to evaluate an hyphotetical dewatering required to mining planning sequence from 2017 to 2042 . Some values used in boundary conditions of steady and transient models were the same to maintain model reliability.

\section{Site Description}

Alegria Mine constitutes a significant iron ore deposit in the eastern portion of the Quadrilátero Ferrífero in Minas Gerais State (Brazil), situated between municipalities of Mariana and Ouro Preto. Access to Alegria Mine can be made preferably via MG 129 Road. Since 1960s, mineral exploration has begun, but only after 1992 Samarco Mineração S.A. has started Alegria Mine pit expansion.

The rocks sequence observed in Alegria Mine region is composed manly by itabirites (metamorphic banded iron formation) of Cauê Formation, Itabira Group (Figure 60). Cauê Formation occurs between two geological units: at the west, by quartzites and phillytes from Caraça Group and at the east by phyllites from Piracicaba Group (VERÍSSIMO, 1999; ROSIÈRE \& CHEMALE, 2000). According to Chiste-Costa et al. (in preparation, Chapter 5), itabirites are present in several lithotypes based on their mineralogical composition, and can be divided into three main subtypes: martitic itabirites (IM), specularitic itabirites (IE), and anfibolitic itabirites (IA). Regional structural geology is marked by open folds with plunge axes to SE, whose central fold corresponds to a sinformal structure called Alegria Syncline (JANUZZI \& ALKIMIN, 1989; ENDO \& CHEMALE Jr., 1992). Other relevant structures are: Alegria major fault, reverse faults and metabasic intrusions that locally can act as flow barriers. Mineral deposit shape follows N-S direction in Alegria South, has an inflection close to João Manuel creek, and undergoes in a SWNE direction in Alegria North.

Cauê Formation itabirites constitute the main regional aquifer, with hydraulic conductivity values up to $1.00 \times 10^{-5} \mathrm{~m} / \mathrm{s}$, but with an average of $4.40 \times 10^{-6} \mathrm{~m} / \mathrm{s}$. Pumping and slug tests showed that specularite itabirite (IE) hydraulic conductivity is $4.55 \times 10^{-6} \mathrm{~m} / \mathrm{s}$, martitic itabirite (IM) is $2.89 \times 10^{-6} \mathrm{~m} / \mathrm{s}$ and anfibolitic itabirite (IA) presents a wide range, between $5.00 \times 10^{-5} \mathrm{~m} / \mathrm{s}$ and $1.00 \times 10^{-7} \mathrm{~m} / \mathrm{s}$. These hydraulic conductivities are locally reduced depending on compositional variations, especially in anfibolitic itabirites, whose weathering produces a clayey material that fills some previously conductive structures.

Alegria Mine numerical model considered Cauê Aquifer as domain; boundary conditions were delimited on interfaces between aquifer and aquitards, due to the hydraulic barrier promoted by Batatal Formation phyllites and on the top by the Piracicaba Group phyllites. 


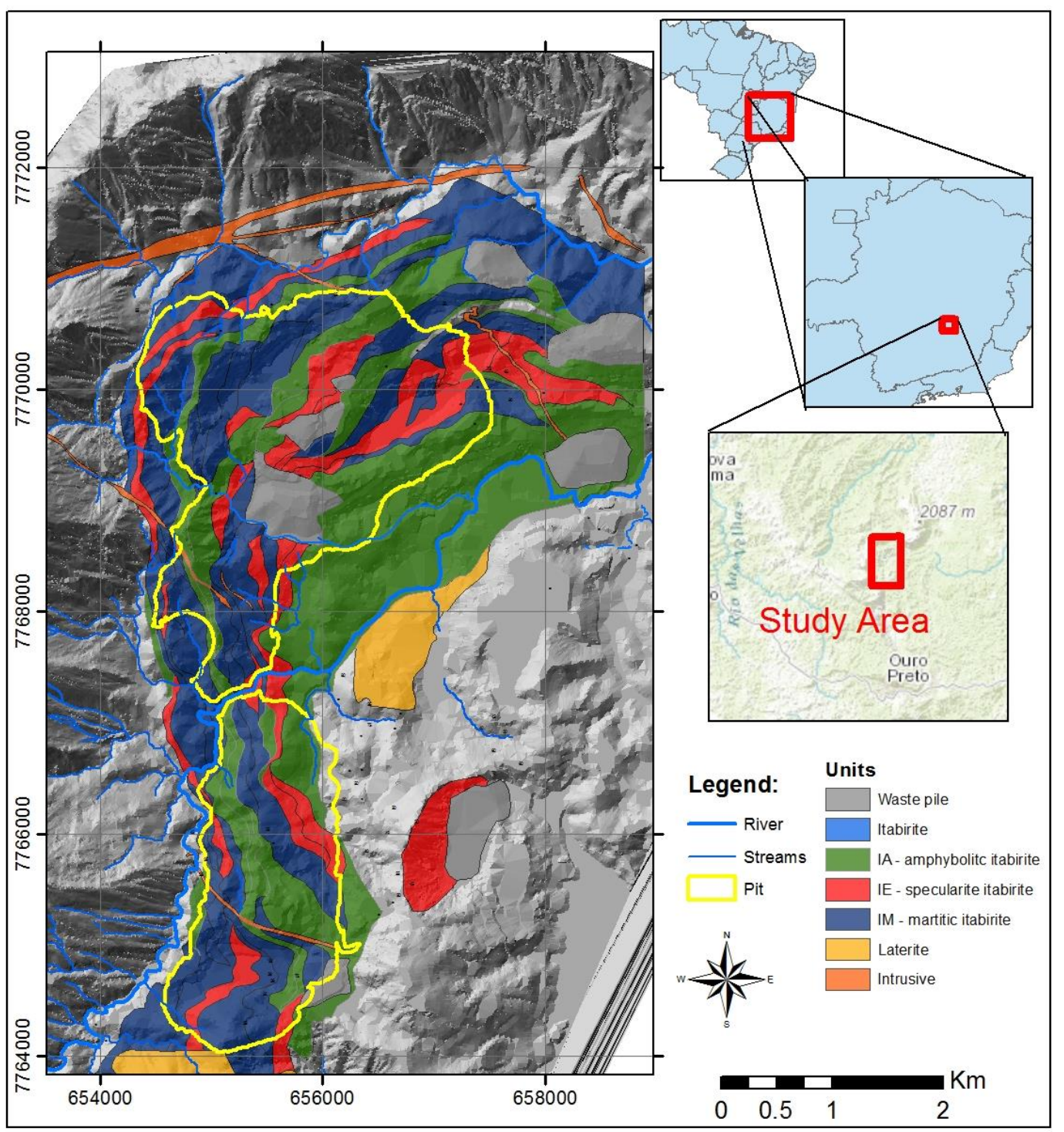

Figure 60 - Geological/hydrogeological units in the Alegria Mine, east part of Quadrilátero Ferrífero.

\section{Domain and Boundary Conditions}

The model domain corresponds to the volume where groundwater flow equation will be solved, and generally is delimited by natural features as known groundwater levels and surface divisors. No-flow is a second-type of boundary condition, which is assigned when groundwater flow rate on boundary contour is zero, occuring when a divisor or a geological unit with very low permeability is present.

In Alegria Mine, domain was limited by natural flow barriers on the basal unit by Batatal Formation phyllites and by Piracicaba Group phyllites and quartzites. Inactive cells were used to designate no-flow condition according to geology (impermeable rocks) and topography (air). Only Cauê aquifer remained as domain active cells. The numerical model was limited by topographic surface itself, and at the bottom by aquifer contact with phyllites, resulting in a total thickness of 
around 1,200 m, within which the hydrogeological units were distributed. In regions where bottom interface was not reached by exploration boreholes, it was assumed that itabirite had not suffered from chemical weathering, presenting, for this reason, low hydraulic conductivity.

GHB's (General Head Boundaries) were assigned to the region between two intrusive rocks in the southern area mapped by Endo \& Fonseca (1992), corresponding to a discharge zone, as well as to that one characterized by indistinct itabirite in the southwest area, defining a water inflow to aquifer. Hydraulic heads and conductance values of these GHBs were defined during steady-state flow calibration, resulting in $880 \mathrm{~m}$ for the southern GHB and $1450 \mathrm{~m}$ for the southwest one. The calibrated conductance of both GHB was $1000 \mathrm{~m}^{2} /$ day in steady and transient states.

The model covers an area of $10.5 \mathrm{~km}$ width by $12.5 \mathrm{~km}$ length, with an active area of 62 $\mathrm{km}^{2}$ approximately. UTM coordinates of model domain starts at $661000 \mathrm{~m}$ in X-direction and at $7771900 \mathrm{~m}$ in Y-direction. Discretization was done in cells of 50 by $50 \mathrm{~m}$. In its final configuration, model constituted a block of 210 lines by 241 columns per layer. In Z-direction, top of the model was delimited at $1660 \mathrm{~m}$ and the bottom at $24 \mathrm{~m}$, according to the size of iron ore exploitable reserve. Model was divided into 42 numerical layers to better control groundwater dewatering by mining benches. Model domain, boundary conditions and discretization are presented in figures 61 and 62. 


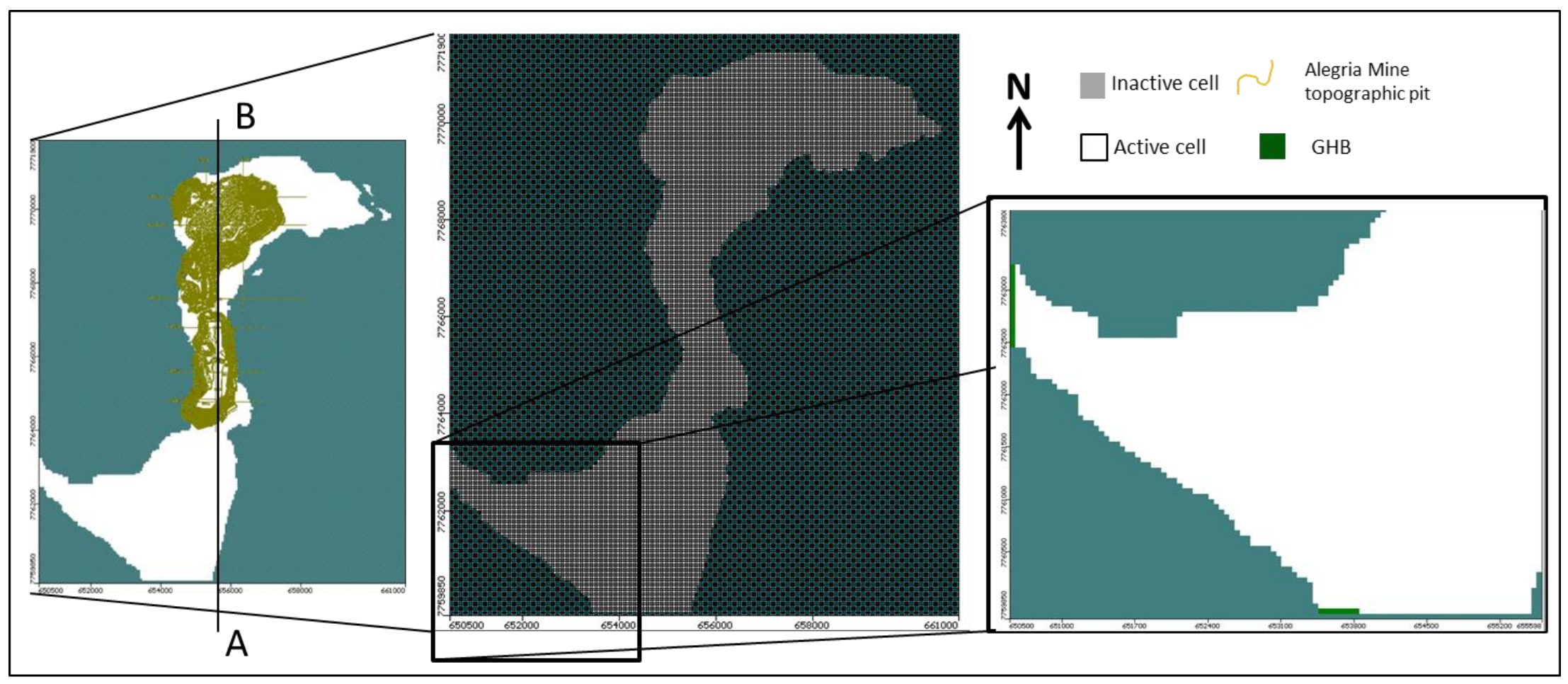

Figure 61 - Model domain and no-flow condition boundaries (inactive cell) in phyllites and quartzites and General Head Bondary (GHB) in the southwest and southern part.

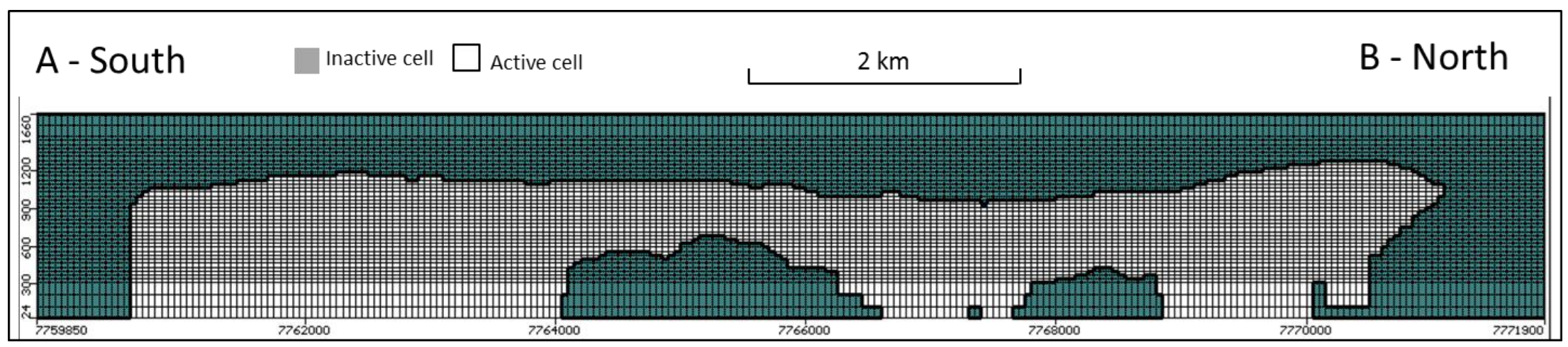

Figure 62- Representative vertical cross section from south to north showed the model domain (vertical $2 x$ ). 


\subsection{Recharge}

Effective recharge represents the fraction of the rainfall that infiltrates in the soil and reaches the aquifers. This boundary was applied to the highest active layer of the model, so that every surface receives recharge. Recharge values adopted represented the inflow that effectively recharges aquifer (and not the total infiltration), since no evapotranspiration data were directly entered in this numerical model. According to Chiste-Costa (in preparation, Chapter 6), water balance and hydrogram analysis showed that effective recharge in Alegria Mine is $31 \%$ of annual rainfall $(\sim 2,200 \mathrm{~mm})$. Several recharge values were simulated in steady-state model and two recharge zones defined and calibrated: one of $610 \mathrm{~mm} / \mathrm{year}$ in the middle and north part and other of $750 \mathrm{~mm} /$ year in higher topographies in south part (Figure 63). This difference is due to the topographic conditions of the site, with the southernmost region consisting of higher reliefs and the central north portion by mining operations.

For transient models (from June 2006 to June 2016), recharge in rainy season (from October to March) was considered as the same for steady-state model and in dry-season (from April to September) it was fixed to zero (Figure 64).

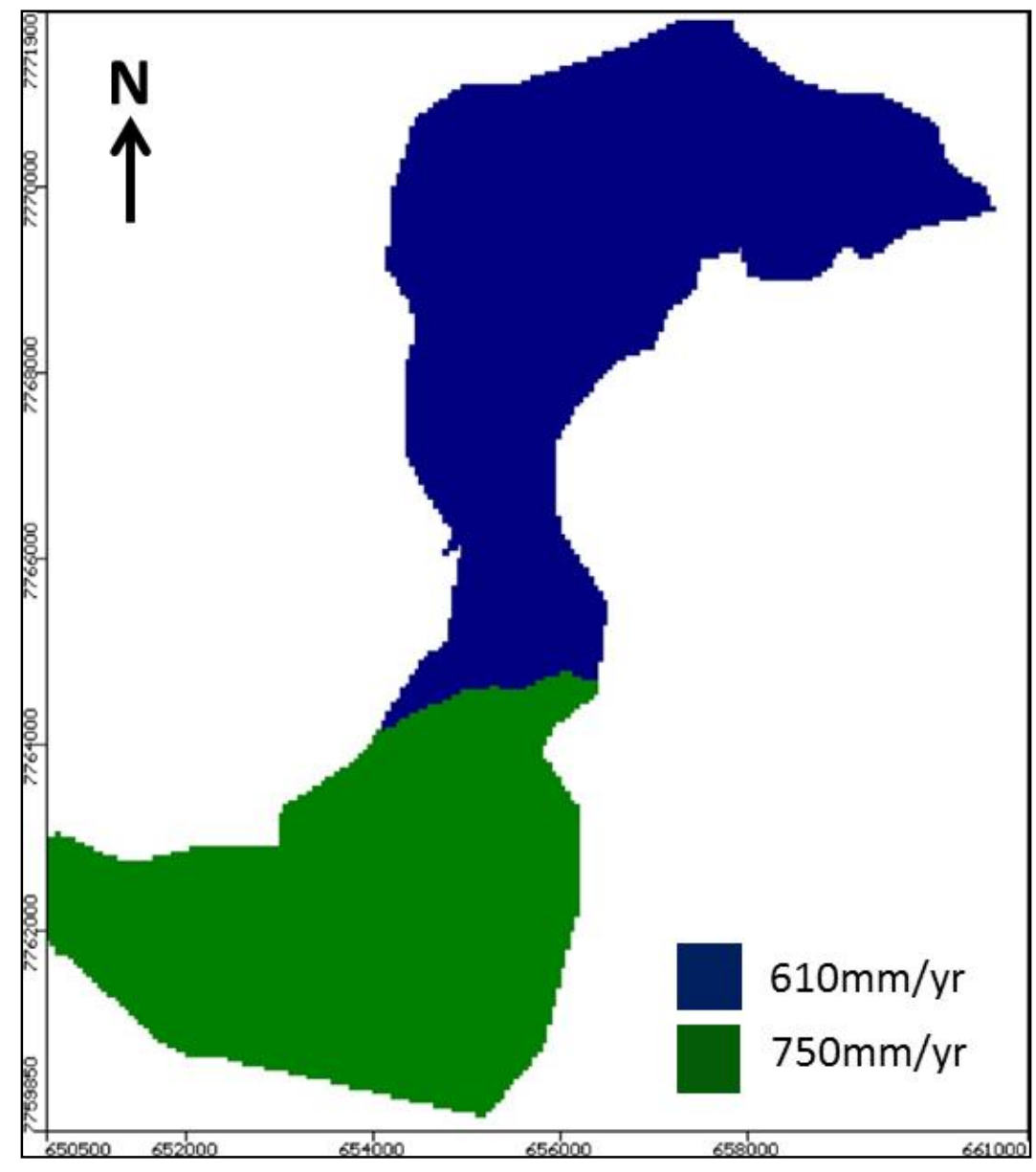

Figure 63 - Recharge zones for steady and transient stages 


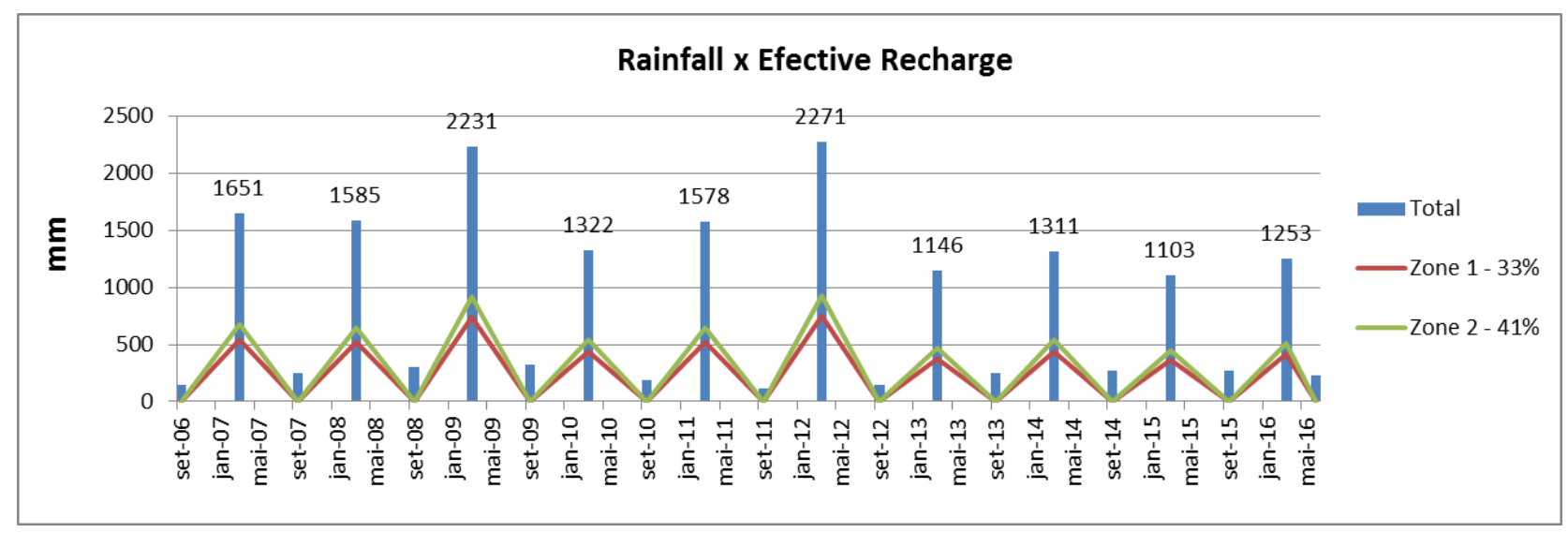

Figure 64 - Recharge values used in the transient model.

\subsection{River and Drain}

River boundary conditions were used to represent Piracicaba River and to evaluate its influent or effluent characteristic in each monitored section. River water level elevation was obtained from topographical map and riverbed elevation was considered as $5-\mathrm{m}$ below water level. Several conductances values were test from $90 \mathrm{~m}^{2} /$ day to $130 \mathrm{~m}^{2} /$ day and the value 100 $\mathrm{m}^{2} /$ day calibrated the model in steady-state model. River properties were kept unchanged for transient model.

Drain boundary conditions were used to Macacos creek, Macaco Barbado creek, Almas creek and Palmital creek in steady-state and transient models to represent the groundwater discharge, according to observed water level monitoring by Chiste-Costa et al. (in preparation, Chapter 6). Drains conductance were initialy set in $100 \mathrm{~m}^{2} /$ day, and calibrated in steady-state model. Drain parameters were kept unchanged for transient model.

\subsection{Pumping Wells}

Nine pumping wells that exist in the area were inserted on Alegria Mine numerical model to calibrate the transient model. In steady-state model, pumping wells were not included, since this model represents the aquifer in pre-pumping conditions. Total pumping rate was incremental over the years. The first pumping well was installed in Alegria Mine in June 2006. Since then, other pumping wells were gradually installed (Figure 65). Geographically, six pumping wells are located in Alegria North and three in Alegria South (Figure 66). 


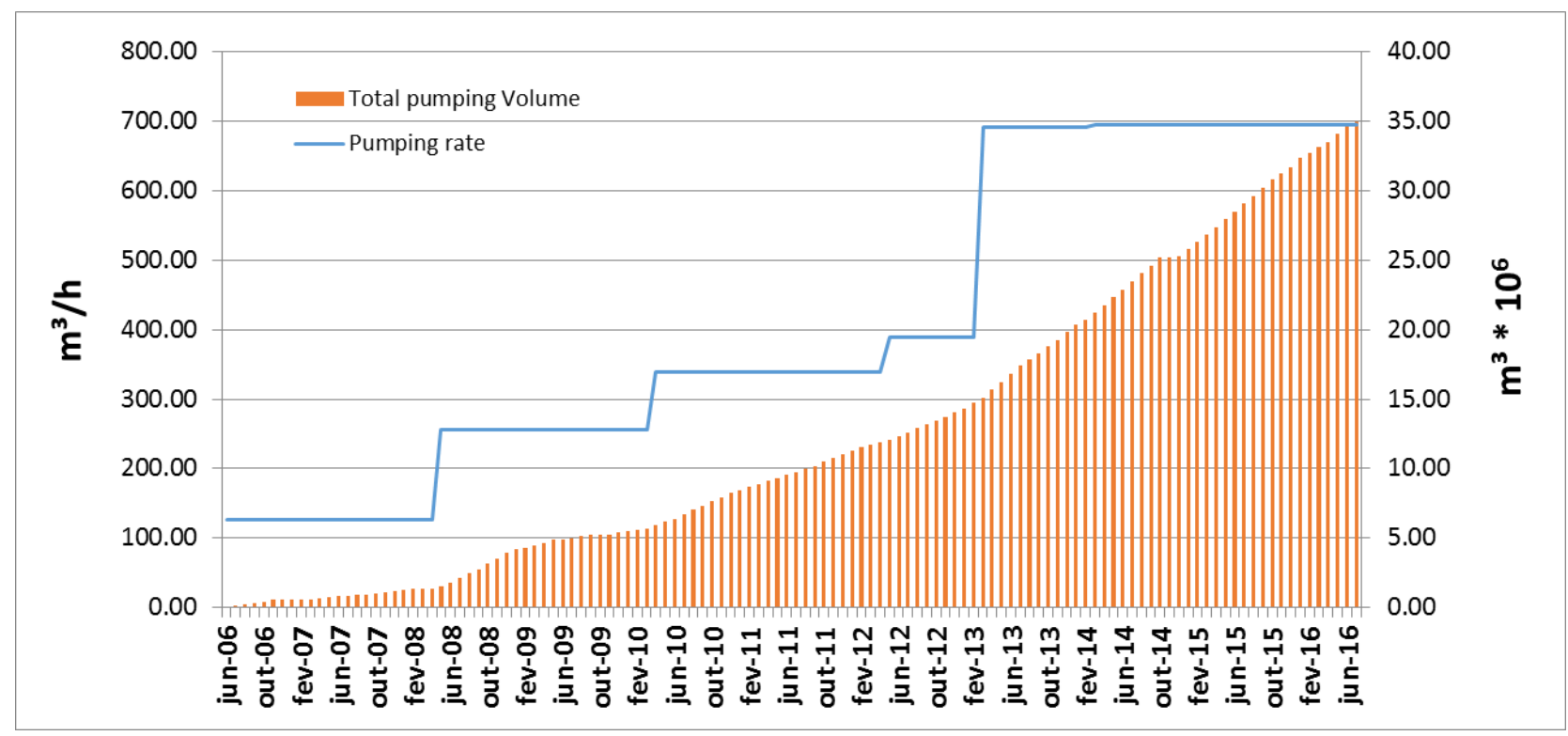

Figure 65 - Pumping rate in Alegria Mine over the years.

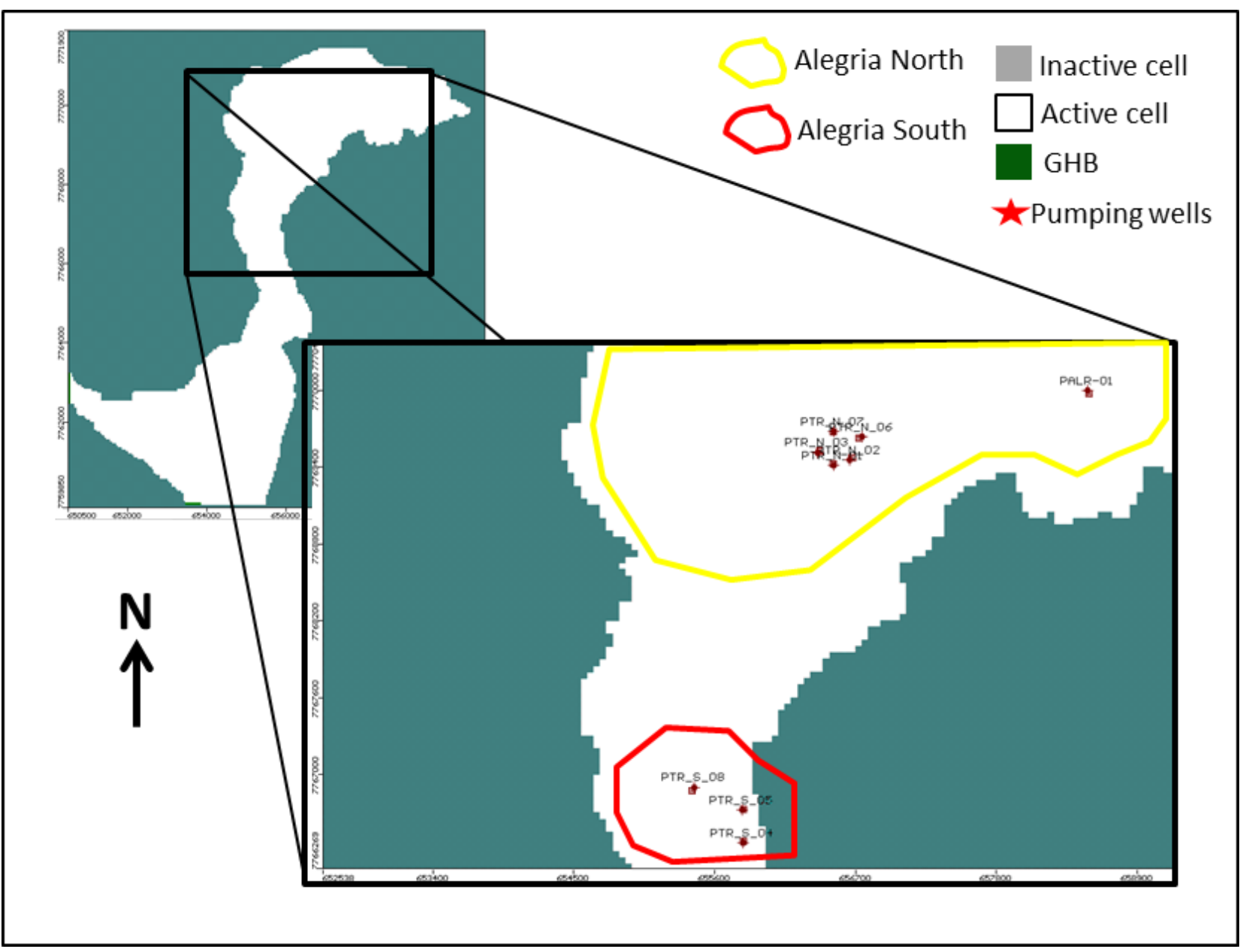

Figure 66 - Pumping well locations in the numeric model.

\section{Hydrogeological framework}

A 3D geological typological model for Alegria Mine is described in Chiste-Costa et al. (Chapter 5). The cross sections were done in GEMS 6.7 (GEOVIA, 2015) in addition to borehole 
lithological loggings were georreferenced and converted in a format compatible with Visual Modflow in order to transcribe the hydrogeological framework to numerical model (Figure 67).

Hydrogeological units were individualized according to their spatial location and anisotropy. Hydraulic conductivity differences in the same unit were due the dip-direction of the hydrogeological units. Layers have E-W orientation in Alegria North and, N-S in Alegria South. Data input of hydraulic conductivity (K), specific yield (Sy) and specific storage (Ss) were based on those obtained by Chiste-Costa (Chapter 6). For each hydroestratigraphical unit, initial values of hydraulic parameters were firstly assigned, and during model processing, they were modified within a reasonable range to achieve calibration. Itabirites hydraulic conductivity mean was 0.36 $\mathrm{m} /$ day (or $4.20 \times 10^{-6} \mathrm{~m} / \mathrm{s}$ ) and specific yield mean $7 \%$

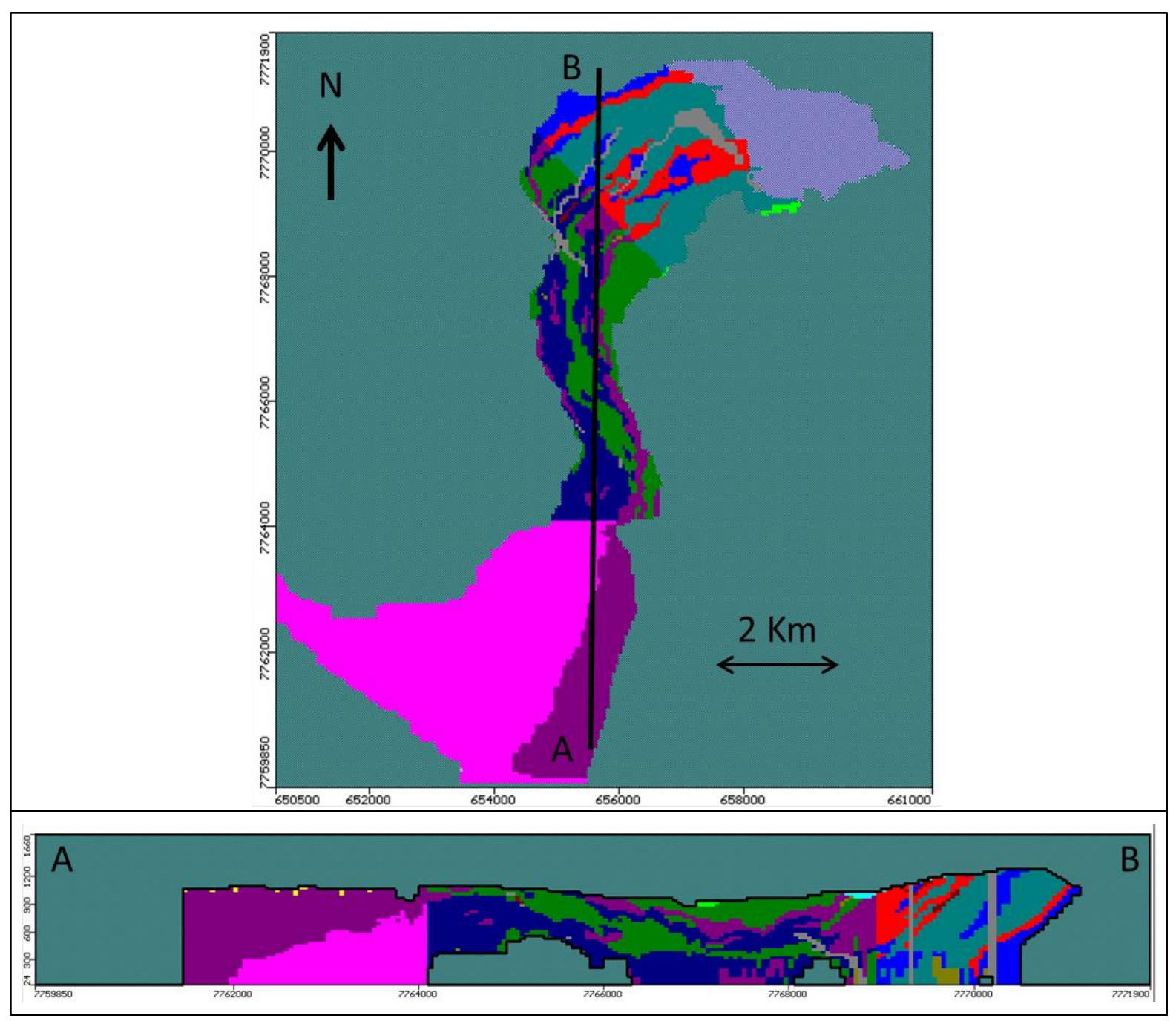

Figure 67 - Alegria Mine hydrogeological framework

\section{Time stress}

Hydraulic head data colected from 32 observed well in May 2006 were used for the calibration steady-state model, before the beginning of pumping wells operation. In that case, a prior distribution of hydraulic head is required to proceed with a transient model. 
Groundwater levels measured in 79 observation wells from June 2006 to June 2016 (Table 11) were input in model domain to calibrate the transient model (Figure 68). Number of hydraulic heads measured over the time stress was variable depending on mining daily routine. For some periods, water level monitoring the field was impossible and at sometimes instruments were destroyed by mining equipments.

Table 11 - Time stress adopted for transient model.

\begin{tabular}{|l|c|c|c|c|}
\hline \multicolumn{2}{|c|}{} & \multicolumn{3}{|c|}{ Data } \\
\cline { 3 - 5 } & From & To & Total \\
\hline $\mathbf{1}$ & Dry period & 0 & 122 & 122 \\
\hline $\mathbf{2}$ & Rainy Season & 122 & 304 & 182 \\
\hline $\mathbf{3}$ & Dry period & 304 & 487 & 183 \\
\hline $\mathbf{4}$ & Rainy Season & 487 & 670 & 183 \\
\hline $\mathbf{5}$ & Dry period & 670 & 853 & 183 \\
\hline $\mathbf{6}$ & Rainy Season & 853 & 1035 & 182 \\
\hline $\mathbf{7}$ & Dry period & 1035 & 1218 & 183 \\
\hline $\mathbf{8}$ & Rainy Season & 1218 & 1400 & 182 \\
\hline $\mathbf{9}$ & Dry period & 1400 & 1583 & 183 \\
\hline $\mathbf{1 0}$ & Rainy Season & 1583 & 1765 & 182 \\
\hline
\end{tabular}

\begin{tabular}{|c|c|c|c|c|}
\hline \multirow{2}{*}{\multicolumn{2}{|c|}{ time }} & \multicolumn{3}{|c|}{ Data } \\
\cline { 3 - 5 } & From & To & Total \\
\hline $\mathbf{1 1}$ & Dry period & 1765 & 1948 & 183 \\
\hline $\mathbf{1 2}$ & Rainy Season & 1948 & 2131 & 183 \\
\hline $\mathbf{1 3}$ & Dry period & 2131 & 2314 & 183 \\
\hline $\mathbf{1 4}$ & Rainy Season & 2314 & 2496 & 182 \\
\hline $\mathbf{1 5}$ & Dry period & 2496 & 2679 & 183 \\
\hline $\mathbf{1 6}$ & Rainy Season & 2679 & 2861 & 182 \\
\hline $\mathbf{1 7}$ & Dry period & 2861 & 3044 & 183 \\
\hline $\mathbf{1 8}$ & Rainy Season & 3044 & 3226 & 182 \\
\hline $\mathbf{1 9}$ & Dry period & 3226 & 3409 & 183 \\
\hline $\mathbf{2 0}$ & Rainy Season & 3409 & 3592 & 183 \\
\hline $\mathbf{2 1}$ & Dry period & 3592 & 3683 & 91 \\
\hline
\end{tabular}

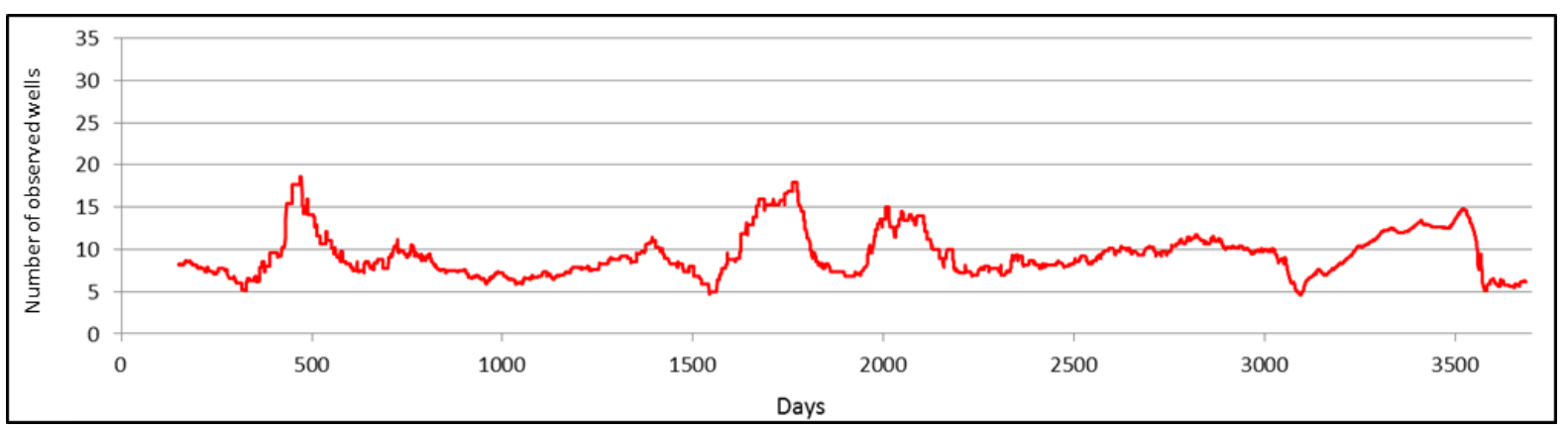

Figure 68 - Number of hydraulic heads observations from June 2006 to June 2016 used in transient model.

\section{Steady-State Model Calibration}

Steady-state model calibration is a process that involves model parameters fitting to reach the best level of correspondence between modeled and natural flow systems. A numerical model is considered calibrated when it can reproduce, in an acceptable level, field hydraulic head and conceptual groundwater net flow. From a deterministic point of view, multiple combinations of parameters can result in model calibration.

Hydraulic heads obtained from 35 observation wells (INA) were considered for model processing. Monitoring campaign of May 2006 was selected because of the large data availability and for being the latest data collected just before pumping wells start to work. 
Several values of hydraulic conductivity and effective recharge were tested to calibrate the steady-state model (Table 11). Calibration has also taken into account riverbed conductance fitting -to determine water exchange between aquifer and river/stream.

Model calibration results show a reasonable match between calculated and observed hydraulic heads, with normalized RMS error of $4.68 \%$ (Figure 69 ). Normalized RMS error, which considers total variation between maximum and minimum hydraulic heads, was less than $10 \%$ (a typical threshold value used to attest if a model is calibrated), given all uncertainties associated to model parameters input. Water mass balance discrepancy was less than $0.001 \%$ (Figure 70 ). Potenciometric and groundwater flow map for steady-state model is presented in figures 71 and 72.

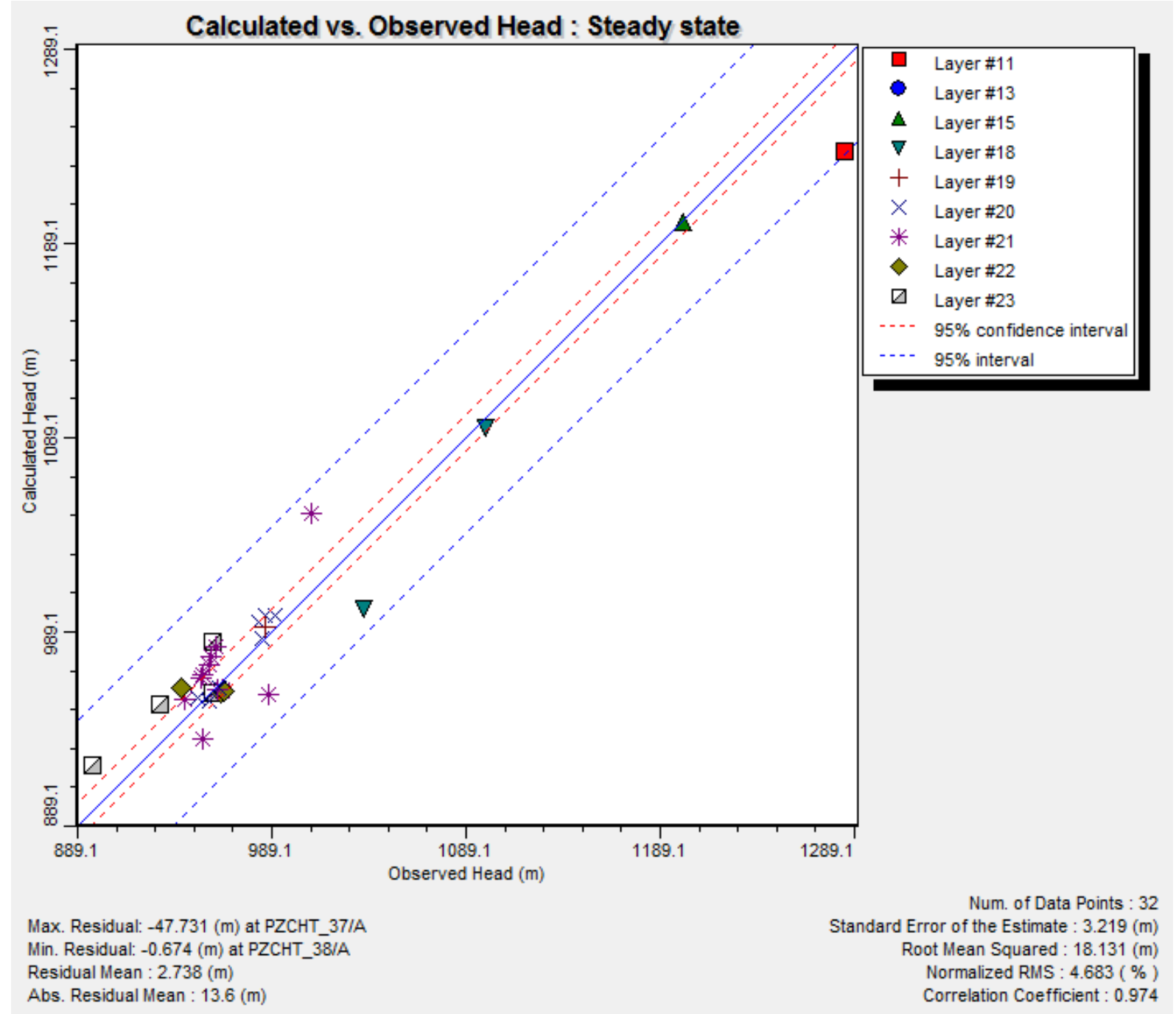

Figure 69 - Plot of hydraulic heads observed versus calculated for steady-state model. 


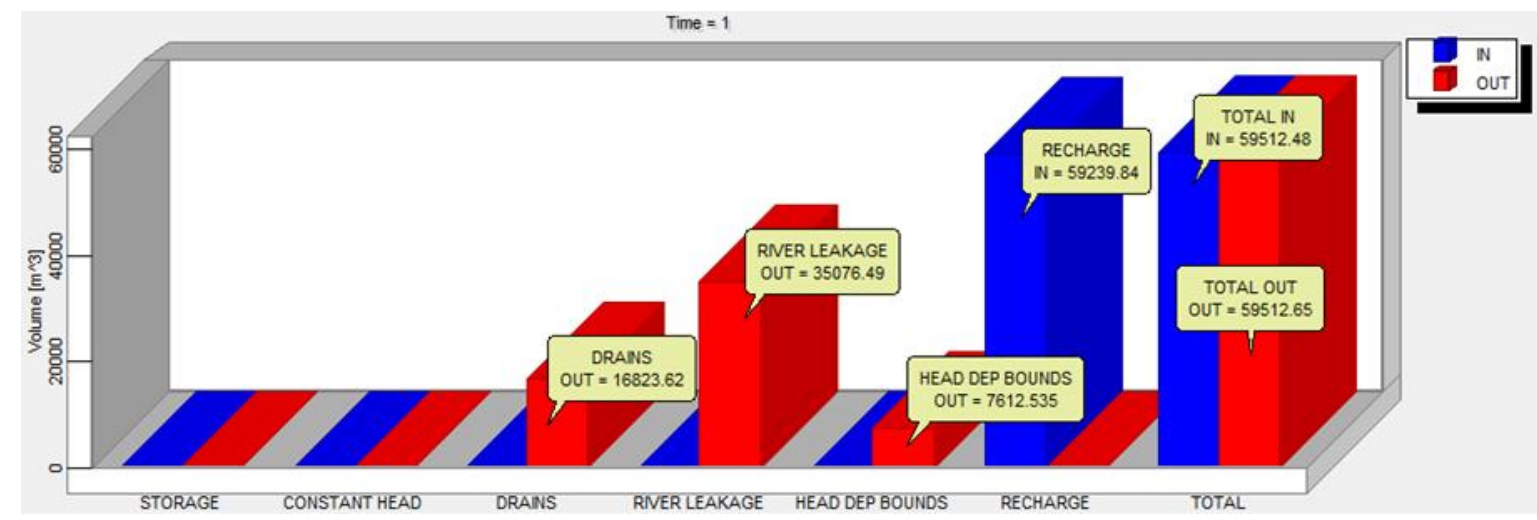

Figure 70 - Water mass balance discrepancy obtained for steady-state model.

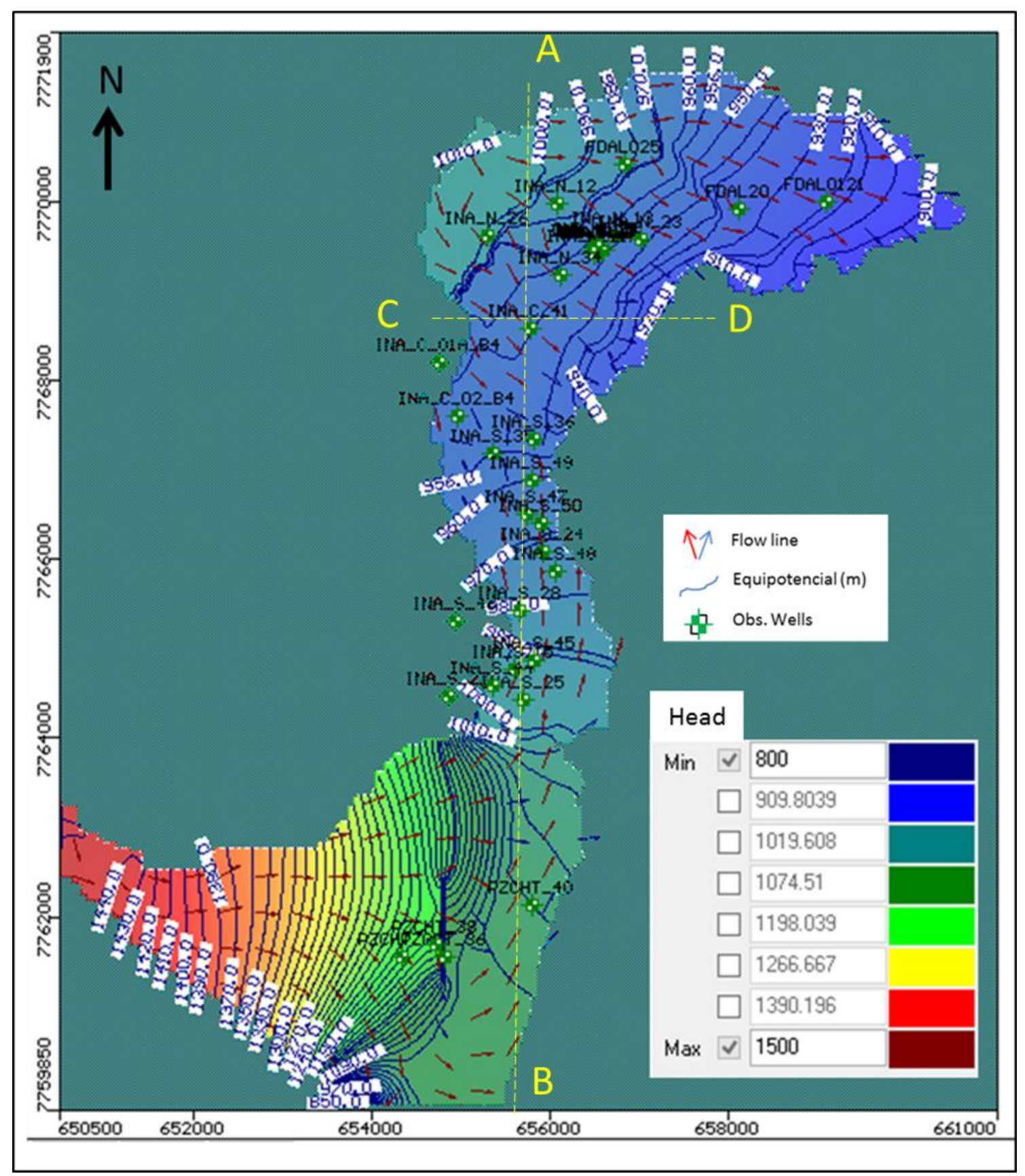

Figure 71 - Potentiometric and groundwater map for steady-state model. 


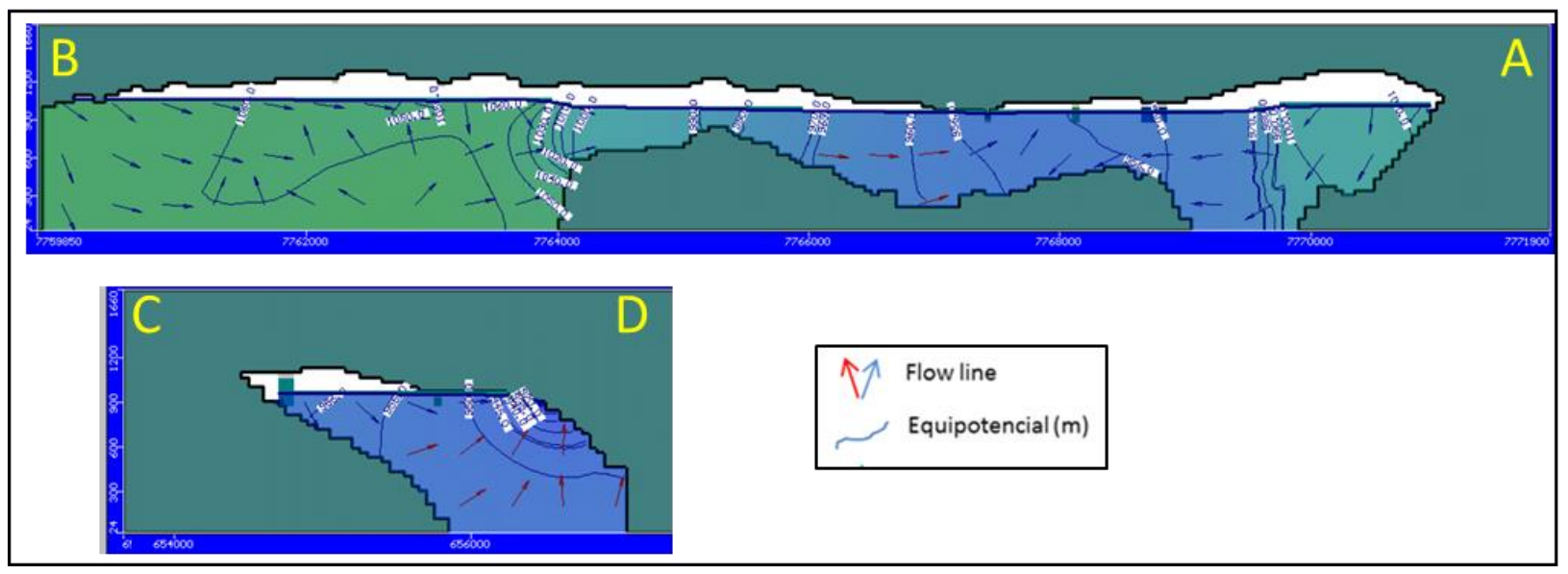

Figure 72 - Vertical sections of potentiometric map for steady-state model.

Zone Budget package in Modflow also can calculate water balance for predetermined cells from calibration results. This tool gives water mass inflow and outflow for each select cell. In this analysis, calculated balance for each area can be compared with real data obtained by monitoring instruments in a given period. Figure 73 summarizes water balance results for main surface water bodies (river and creeks), reflecting the medium equilibrium conditions before operation of the pumping wells. Calculated and observed flow rates present similar values, except for Piracicaba River Station EF01, whose greater water inflow come from outside domain.

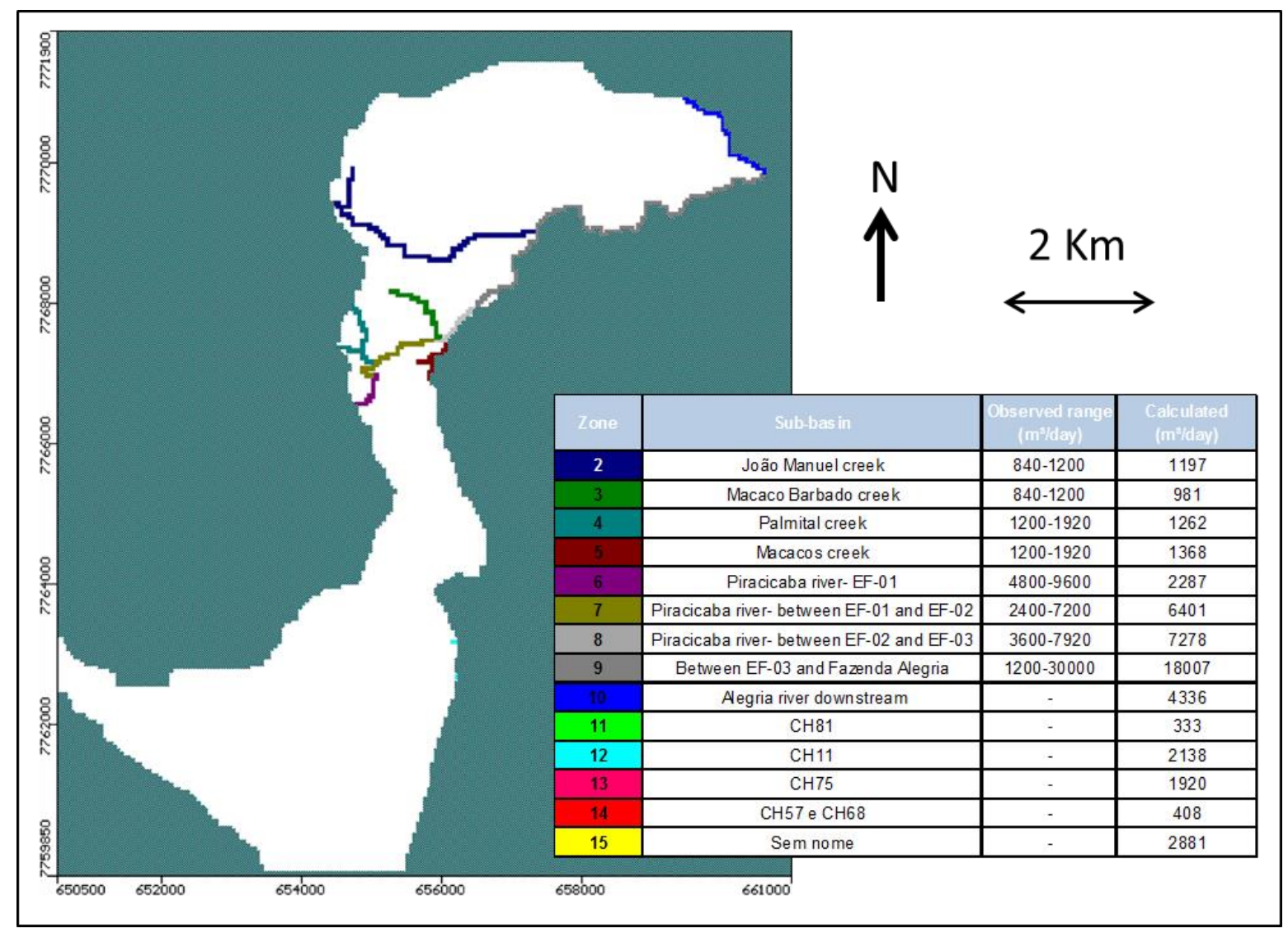

Figure 73 - Calculated and observed flow rates comparison for Piracicaba River and creeks for steady-state model. 


\section{Transient Model Calibration}

After steady-state model calibration, hydraulic heads distribution calculated from it was used as initial condition to calibrate the transient model as well as hydraulic parameters of each hidrostratigraphical unit (K, Ss and Sy) and recharge zones and values. The total calibrated period comprised was from June 2006 to July 2016.

Transient model was calibrated considering the same parameter values adopted to steady-state model. The hydrodynamic properties associated to the hydrogeological units that resulted in the best transient calibration were the same used in the calibration in steady model (Table 12). The recharge percentages were the same as the steady calibration stage. In the dry season months, effective recharge was considered null. 
Table 12 - Initial, range and calibrated parameters values for steady-state and transient models

\begin{tabular}{|c|c|c|c|c|c|c|c|c|c|c|c|c|c|}
\hline \multirow{2}{*}{ Zone } & \multirow{2}{*}{ Hydrogeologic unit } & \multicolumn{3}{|c|}{ Initial Values (m/s) } & \multicolumn{3}{|c|}{ Range $(\mathrm{m} / \mathrm{s})$} & \multirow{2}{*}{ Reference } & \multicolumn{3}{|c|}{ Calibrated Value (m/s) } & \multirow{2}{*}{ Ss $(1 / m)$} & \multirow{2}{*}{ Sy } \\
\hline & & $\mathrm{kx}$ & Ky & $\mathrm{K}_{2}$ & $\mathrm{kx}$ & Ky & $\mathrm{K}_{2}$ & & $\mathrm{kx}$ & Ky & $\mathrm{K}_{2}$ & & \\
\hline 1 & Air & \multicolumn{3}{|c|}{-} & \multicolumn{3}{|c|}{ - } & - & \multicolumn{3}{|c|}{-} & - & - \\
\hline 2 & IM - Martitic itabirite (Alegria Center and South) & $3.00 \mathrm{E}-06$ & $2.81 \mathrm{E}-06$ & $1.00 \mathrm{E}-06$ & [1E-05...1E-07] & {$[1 \mathrm{E}-05 \ldots 1 \mathrm{E}-07]$} & {$[1 \mathrm{E}-05 \ldots 1 \mathrm{E}-07]$} & Chapter 6 & $9.00 \mathrm{E}-06$ & $1.81 \mathrm{E}-05$ & $9.00 \mathrm{E}-06$ & 0.001 & $6.00 \%$ \\
\hline 3 & IA - Anfibolitic itabirite (Alegria South) & $2.00 \mathrm{E}-07$ & $3.40 \mathrm{E}-06$ & $1.00 \mathrm{E}-06$ & {$[1 \mathrm{E}-06 \ldots 1 \mathrm{E}-08]$} & {$[1 \mathrm{E}-06 \ldots 1 \mathrm{E}-08]$} & [1E-06..1E-08] & Chapter 6 & $7.00 \mathrm{E}-06$ & $1.40 \mathrm{E}-05$ & $7.00 \mathrm{E}-06$ & 0.001 & $6.00 \%$ \\
\hline 4 & IA - Anfibolitic itabirite (Alegria North) & $3.00 \mathrm{E}-06$ & $5.00 \mathrm{E}-07$ & $4.00 \mathrm{E}-06$ & [1E-06...1E-08] & [1E-06...1E-08] & {$[1 \mathrm{E}-06 \ldots 1 \mathrm{E}-08]$} & Chapter 6 & $1.00 \mathrm{E}-06$ & $5.00 \mathrm{E}-07$ & $1.00 \mathrm{E}-06$ & 0.003 & $7.00 \%$ \\
\hline 5 & IA - Anfibolitic itabirite (Alegria Center) & $1.00 \mathrm{E}-06$ & $4.00 \mathrm{E}-06$ & $1.00 \mathrm{E}-06$ & {$[1 \mathrm{E}-06 \ldots 1 \mathrm{E}-08]$} & {$[1 \mathrm{E}-06 \ldots 1 \mathrm{E}-08]$} & [1E-06...1E-08] & Chapter 6 & $4.00 \mathrm{E}-06$ & $2.00 \mathrm{E}-06$ & $4.00 \mathrm{E}-06$ & 0.003 & $7.00 \%$ \\
\hline 6 & IE - Specularitic itabirite (Alegria Center and South) & $6.00 \mathrm{E}-06$ & $5.00 \mathrm{E}-06$ & $5.00 \mathrm{E}-06$ & [1E-05...1E-06] & [1E-05...1E-06] & [1E-05...1E-06] & Chapter 6 & $8.00 \mathrm{E}-06$ & $1.60 \mathrm{E}-05$ & $8.00 \mathrm{E}-06$ & 0.001 & $6.00 \%$ \\
\hline 7 & Phyllite & $1.00 \mathrm{E}-08$ & $1.00 \mathrm{E}-08$ & $1.00 \mathrm{E}-08$ & [1E-07 ...1E-09] & [1E-07...1E-09] & [1E-07...1E-09] & Mourão 2007 & $1.00 \mathrm{E}-08$ & $1.00 \mathrm{E}-08$ & $1.00 \mathrm{E}-08$ & 0.0007 & $0.50 \%$ \\
\hline 8 & Quartzite & $1.00 \mathrm{E}-08$ & $4.00 \mathrm{E}-07$ & $1.00 \mathrm{E}-08$ & [1E-07 ...1E-09] & [1E-07...1E-09] & [1E-07...1E-09] & Mourão 2008 & $1.00 \mathrm{E}-07$ & $1.00 \mathrm{E}-07$ & $1.00 \mathrm{E}-07$ & 0.0008 & $4.00 \%$ \\
\hline 9 & Intrusive rock & $1.00 \mathrm{E}-08$ & $3.00 \mathrm{E}-08$ & $5.00 \mathrm{E}-08$ & [1E-08...1E-09] & [1E-08...1E-09] & [1E-08...1E-09] & - & $5.00 \mathrm{E}-08$ & $5.00 \mathrm{E}-08$ & $5.00 \mathrm{E}-08$ & 0.0007 & $0.50 \%$ \\
\hline 10 & IM - Martitic itabirite (Alegria north) & $3.00 \mathrm{E}-06$ & $4.00 \mathrm{E}-07$ & $6.00 \mathrm{E}-06$ & {$[1 \mathrm{E}-06 \ldots 1 \mathrm{E}-07]$} & [1E-06...1E-07] & [1E-06...1E-07] & Chapter 6 & $1.00 \mathrm{E}-06$ & $5.00 \mathrm{E}-07$ & $1.00 \mathrm{E}-06$ & 0.003 & $7.00 \%$ \\
\hline 11 & Schist & $3.00 \mathrm{E}-08$ & $2.00 \mathrm{E}-08$ & 3.00E-08 & [1E-08...1E-09] & [1E-08...1E-09] & [1E-08...1E-09] & Mourão 2008 & $5.00 \mathrm{E}-08$ & $5.00 \mathrm{E}-08$ & $5.00 \mathrm{E}-08$ & 0.0007 & $0.50 \%$ \\
\hline 12 & Waste pile & $2.00 \mathrm{E}-07$ & $3.00 \mathrm{E}-07$ & $4.00 \mathrm{E}-07$ & [1E-06 ..1E-08] & [1E-06...1E-08] & {$[1 \mathrm{E}-06 \ldots 1 \mathrm{E}-08]$} & - & $1.00 \mathrm{E}-06$ & $1.00 \mathrm{E}-06$ & $1.00 \mathrm{E}-06$ & 0.003 & $7.00 \%$ \\
\hline 13 & IE - Specularitic itabirite (Alegria North) & $1.00 \mathrm{E}-05$ & $2.00 \mathrm{E}-05$ & $2.00 \mathrm{E}-05$ & [1E-05...1E-06] & [1E-05...1E-06] & [1E-05...1E-06] & Chapter 6 & $4.00 \mathrm{E}-06$ & $2.00 \mathrm{E}-06$ & $4.00 \mathrm{E}-06$ & 0.003 & $7.00 \%$ \\
\hline 14 & Itabirite indistrict South & $3.06 \mathrm{E}-06$ & $5.60 \mathrm{E}-06$ & $1.81 \mathrm{E}-06$ & [1E-05...1E-07] & [1E-05 ...1E-07] & [1E-05...1E-07] & Chapter 6 & $1.81 \mathrm{E}-07$ & $3.60 \mathrm{E}-07$ & $1.81 \mathrm{E}-07$ & 0.001 & $7.00 \%$ \\
\hline 15 & Laterite & $3.00 \mathrm{E}-06$ & $3.00 \mathrm{E}-06$ & $3.00 \mathrm{E}-06$ & [1E-05...1E-06] & [1E-05...1E-06] & {$[1 \mathrm{E}-05 \ldots 1 \mathrm{E}-06]$} & - & $6.00 \mathrm{E}-06$ & $6.00 \mathrm{E}-06$ & $6.00 \mathrm{E}-06$ & 0.001 & $6.00 \%$ \\
\hline 16 & Itabirite indivise North & $8.03 E-06$ & $6.30 \mathrm{E}-06$ & $6.20 \mathrm{E}-06$ & [1E-05...1E-07] & [1E-05...1E-07] & [1E-05...1E-07] & Chapter 6 & $3.40 \mathrm{E}-06$ & $1.70 \mathrm{E}-06$ & $3.40 \mathrm{E}-06$ & 0.003 & $7.00 \%$ \\
\hline
\end{tabular}


Transient model calibration over 10 years showed satisfactory normalized RMS, residual mean and standard error of the estimate (Figures 74, 75 and 76). It is important to note small variability of calibrated error, with regard to seasonality and pumping wells operation.

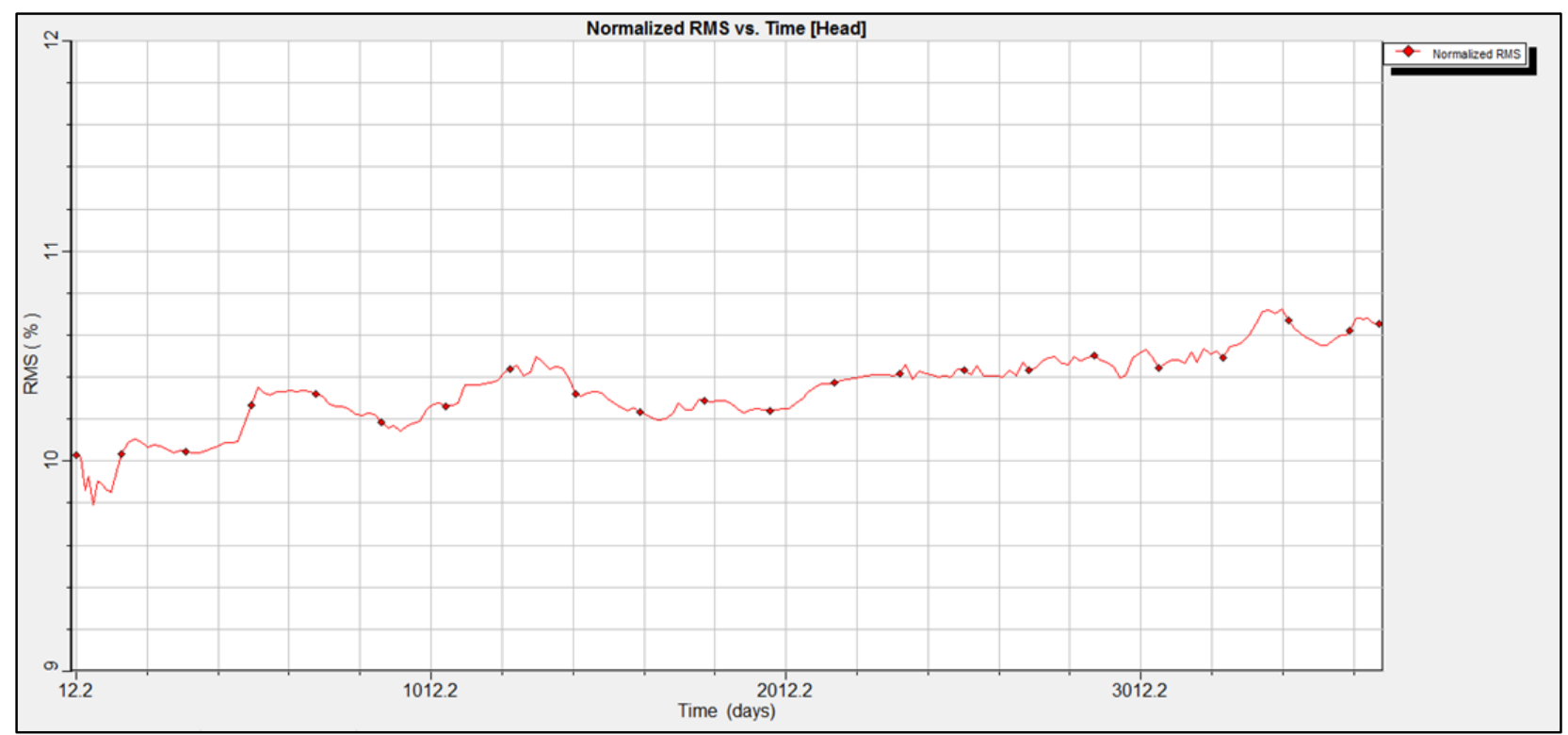

Figure 74 - Normalized RMS error versus time for transient model.

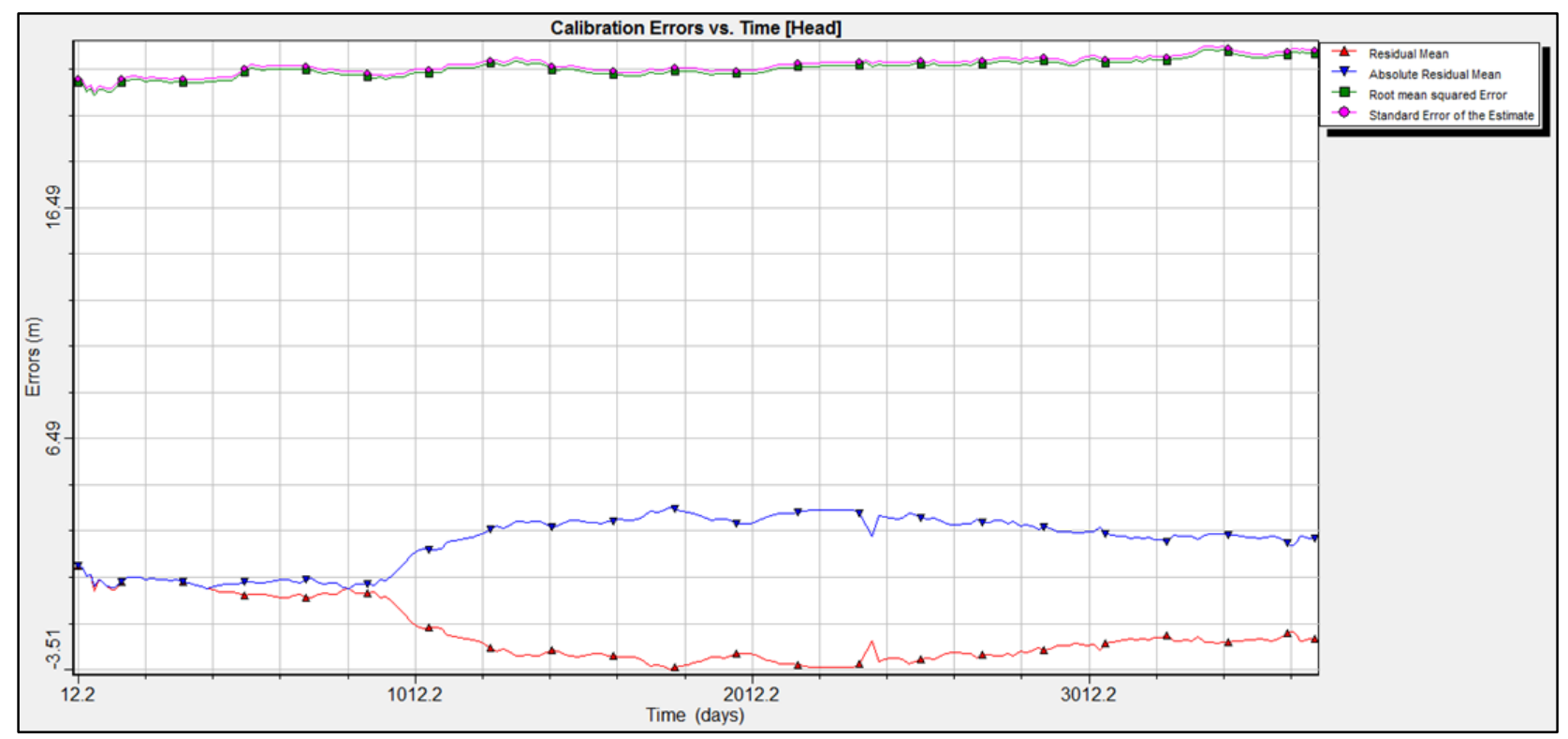

Figure 75 - Residual Mean, Absolute Residual Mean, RMS Error and Standard Error. 


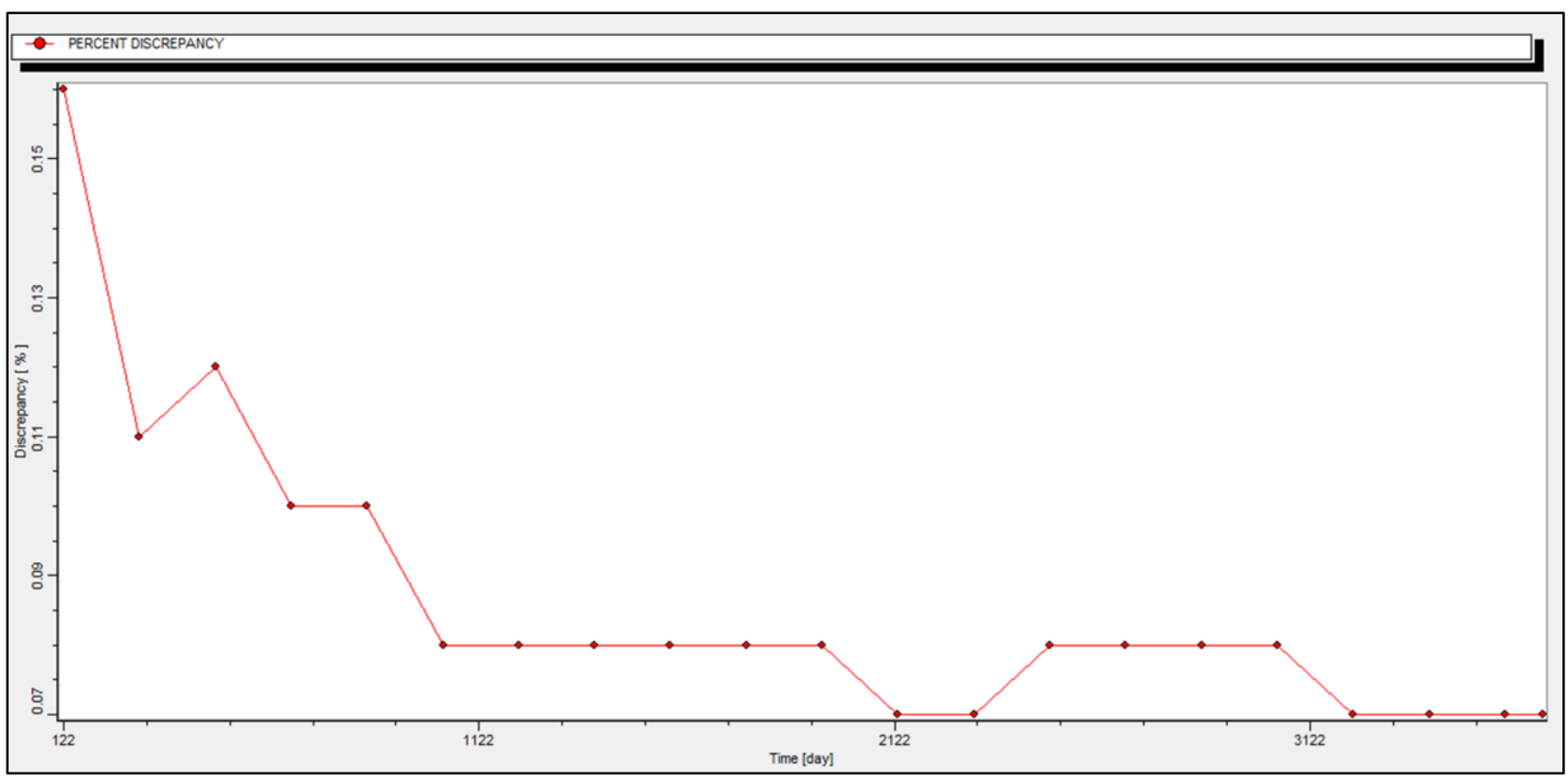

Figure 76- Water mass balance discrepancy (\%) for transient model.

\section{Sensitivity Analysis}

Sensitivity analysis was performed to quantify uncertainty in steady-state calibrated model given by aquifer parameters and boundary conditions. As expected, the calibration of the model is more sensitive to variations in the recharge and hydraulic conductivity. Calibration errors were monitored by increasing and decreasing original hydraulic conductivity calibrated values in $25 \%$ and $50 \%$. Recharge values were also changed in the same proportion, using the original steady-state calibrated model (Figure 77).

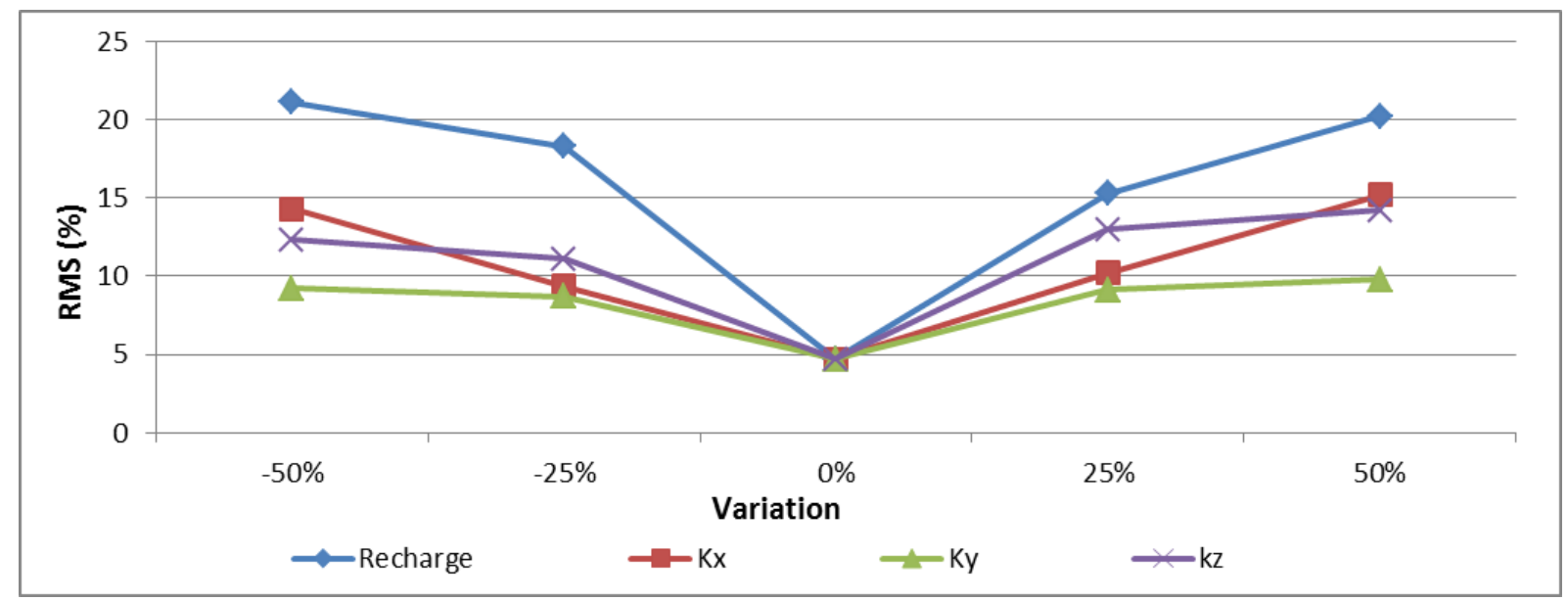

Figure 77- Sensitivity analysis of the calibrated model considering the recharge and hydraulic conductivity. 


\section{Mine Dewatering Simulations}

\subsection{Mine planning schedule}

Significant mine expansion may lead to changes in future dewatering requirements, compared to past operations at the site, as number of pumping wells, location and total withdrawal flow rate. For this reason, numerical modelling is essential to design a suitable pumping system to achieve mine dewatering, just as to predict unfavourable consequences, as impacts on surface water availability.

Based on the transient model calibrated for a 10-years pumping scenario (2006-2016), another transient model was constructed to simulate Alegria Mine dewatering between 2016 and 2042. Each simulation was run several times considering gradual installation of additional pumping wells until water table at each sector of Alegria Mine were brought down to a few meters below mine pit topography scheduled by mine planning from 2017 to 2042 (Figures 71 and 72 ). Drawdown simulation model comprised a period of 25 years, from July 2016 to December 2042, divided in 27 periods of stress.

Alegria North and Alegria Center topographic mine sequences show that each pit geometry will intercept groundwater level in 2032, whereas in Alegria South interception will occur in 2021 (Figures 78 e 79). To feasibility mining activities, planning dewatering becomes obligatory (Table 13). 

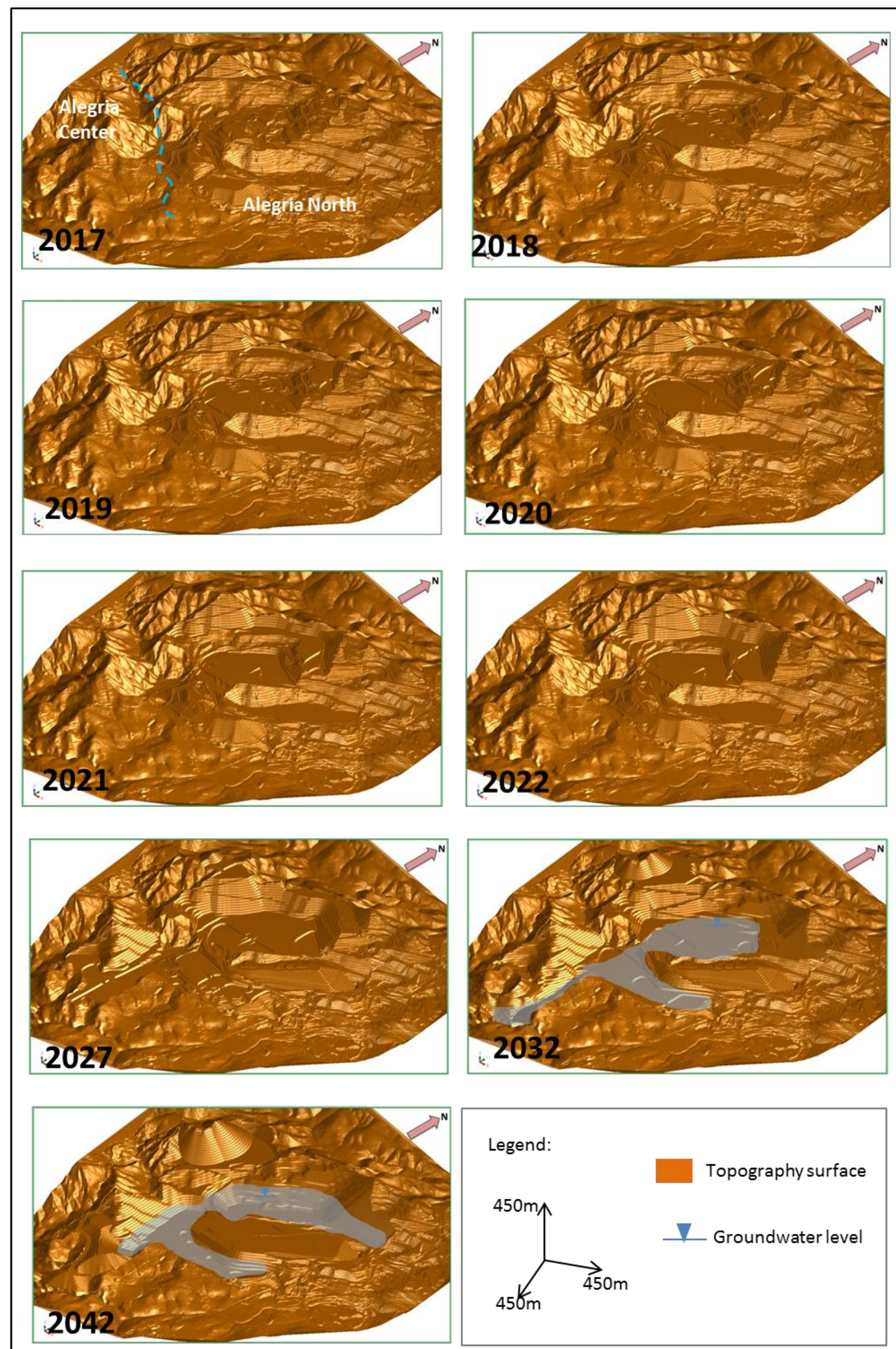

Figure 78- Mine planning schedule for Alegria North an Alegria Center 


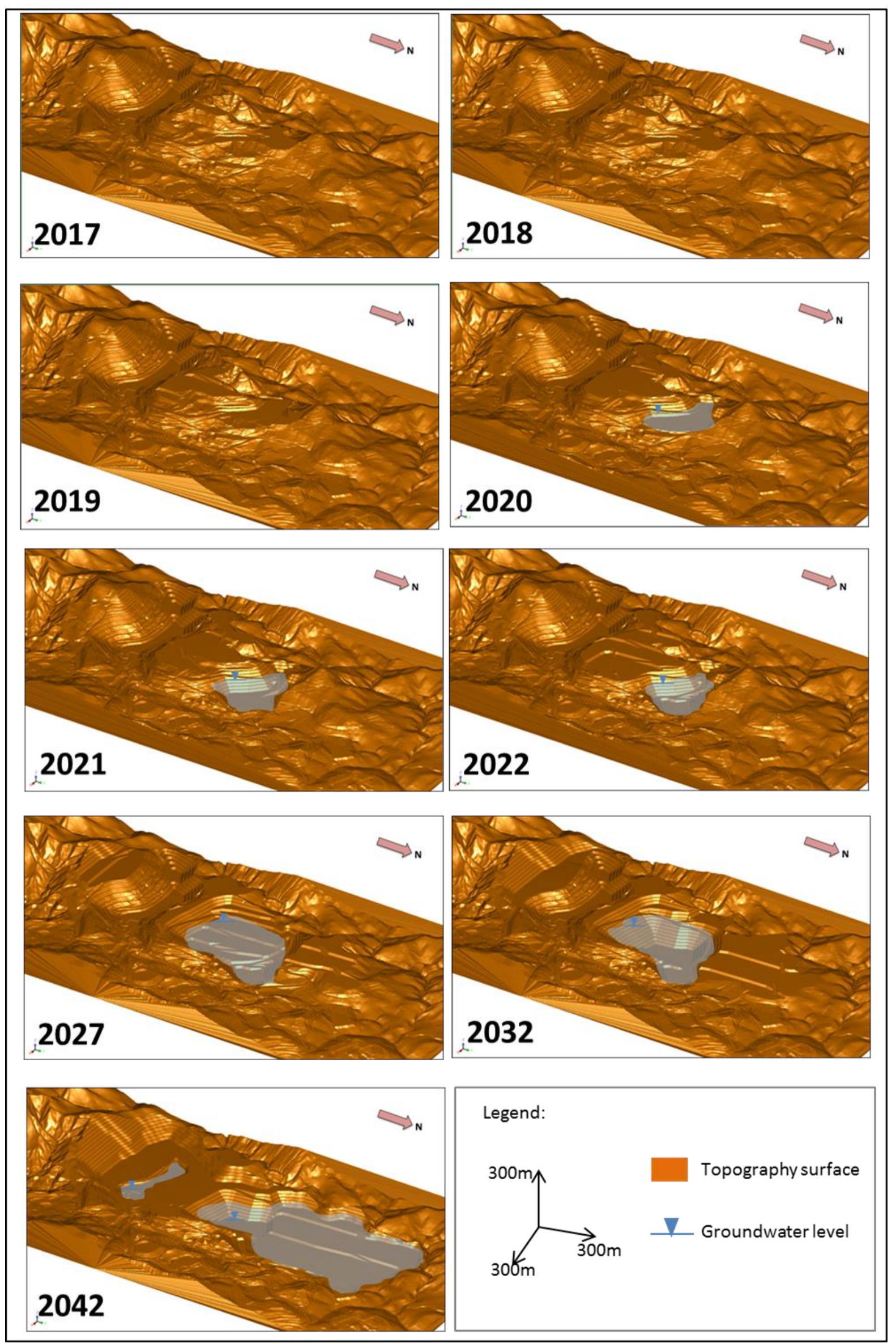

Figure 79- Mine planning schedule for Alegria South 
Table 13 - Stress period versus pit bottom.

\begin{tabular}{|c|c|c|c|c|c|}
\hline \multirow{2}{*}{ Stress Period } & \multirow{2}{*}{ Year } & \multirow{2}{*}{ Days } & \multicolumn{3}{|c|}{ Bottom pit $(\mathrm{m})$} \\
\cline { 4 - 6 } & & & North & Center & South \\
\hline 1 & 2016 & 185 & 1120 & 1040 & 1008 \\
\hline 2 & 2017 & 550 & 1120 & 1040 & 1008 \\
\hline 3 & 2018 & 915 & 1104 & 1040 & 1008 \\
\hline 4 & 2019 & 1280 & 1104 & 1040 & 1008 \\
\hline 5 & 2020 & 1646 & 1104 & 1040 & 992 \\
\hline 6 & 2021 & 2011 & 1104 & 1040 & 968 \\
\hline 7 & 2022 & 2376 & 1040 & 980 & 968 \\
\hline 12 & 2027 & 4202 & 1016 & 956 & 946 \\
\hline 17 & 2032 & 6029 & 992 & 880 & 896 \\
\hline 27 & 2042 & 9681 & 944 & 880 & 896 \\
\hline
\end{tabular}

\subsection{Simulation Results}

Mine dewatering simulations were performed based on the transient model calibrated for a 10-years pumping scenario (2006-2016).

From 2017 to 2042 (hyphotetical simulation), a total of 96 wells were inserted in Alegria Mine for dewatering simulation, some of them located outside the area of influence of mining operations and 23 to replace pumping wells destroyed because natural mine expansion.

According to figure 80, pit deepening is planned to continue beyond 2023 for Alegria North. Prior to this, expansion will be predominantly sideways, since water level currently is already under 1,000 m elevation. Although mining expansion won't intercept groundwater level in a short time, dewatering system in Alegria North (Figure 81) will support iron ore access in Alegria Center. Projects under development by Samarco's mine planning team indicate that after 10 years, mining operations will be intensified in depth with open benchs. In this situation, mine early dewatering becomes necessary with energy cost savings and number of pumping wells optimization.

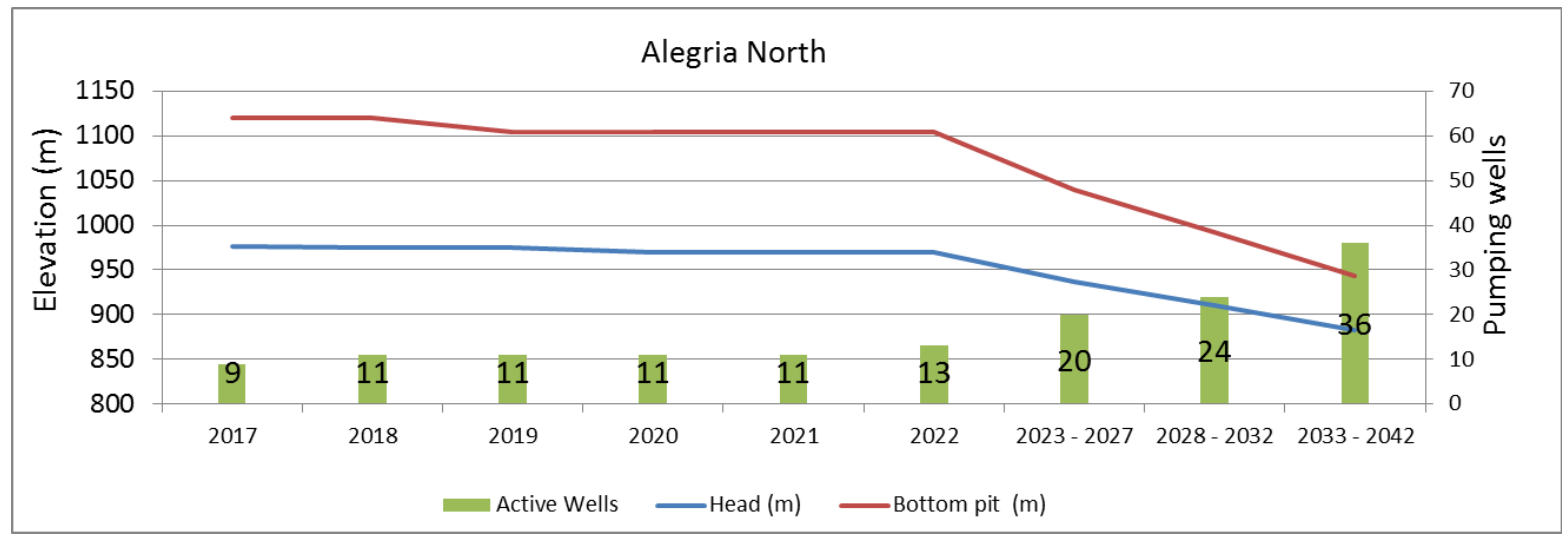

Figure 80 - Mine pit bottom elevation and drawdown level reached by pumping wells in Alegria North.

Alegria Center will begin its operation between 2022 and 2027, reaching final pit bottom at $880 \mathrm{~m}$ elevation in 2032. During this time, a $160 \mathrm{~m}$ pit deepening is planned, with installation 
of new pumping wells. Simulations show that after reaching the expected water level for Alegria Center pit, the cone of depression continued to expand, mainly due to a dewatering front coming from Alegria North (Figure 82). Figure 83 presents groundwater levels and flow direction related to pit bottom elevations in a model section after the pumping starts in 2027 and 2032.
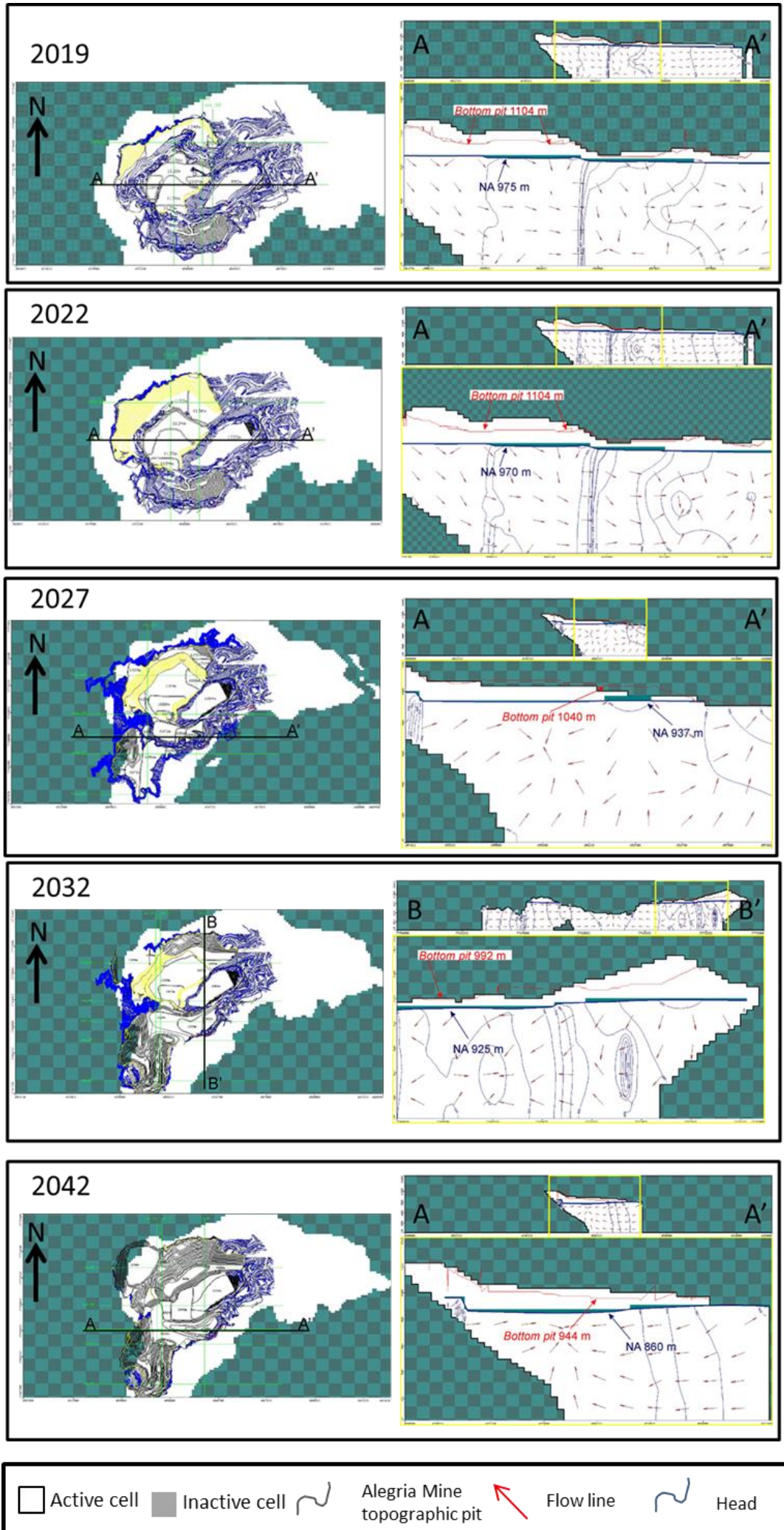

Figure 81 - Dewatering simulation for Alegria North. 


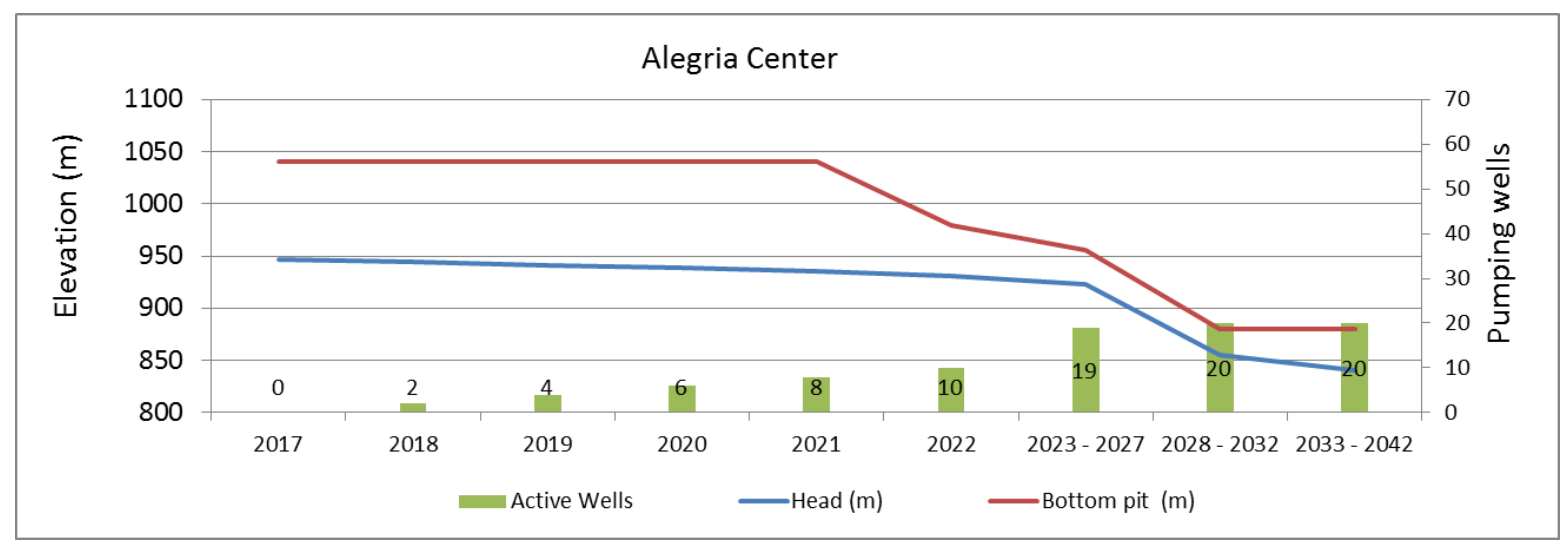

Figure 82 - Mine pit bottom elevation and drawdown level reached by pumping wells in Alegria Center.
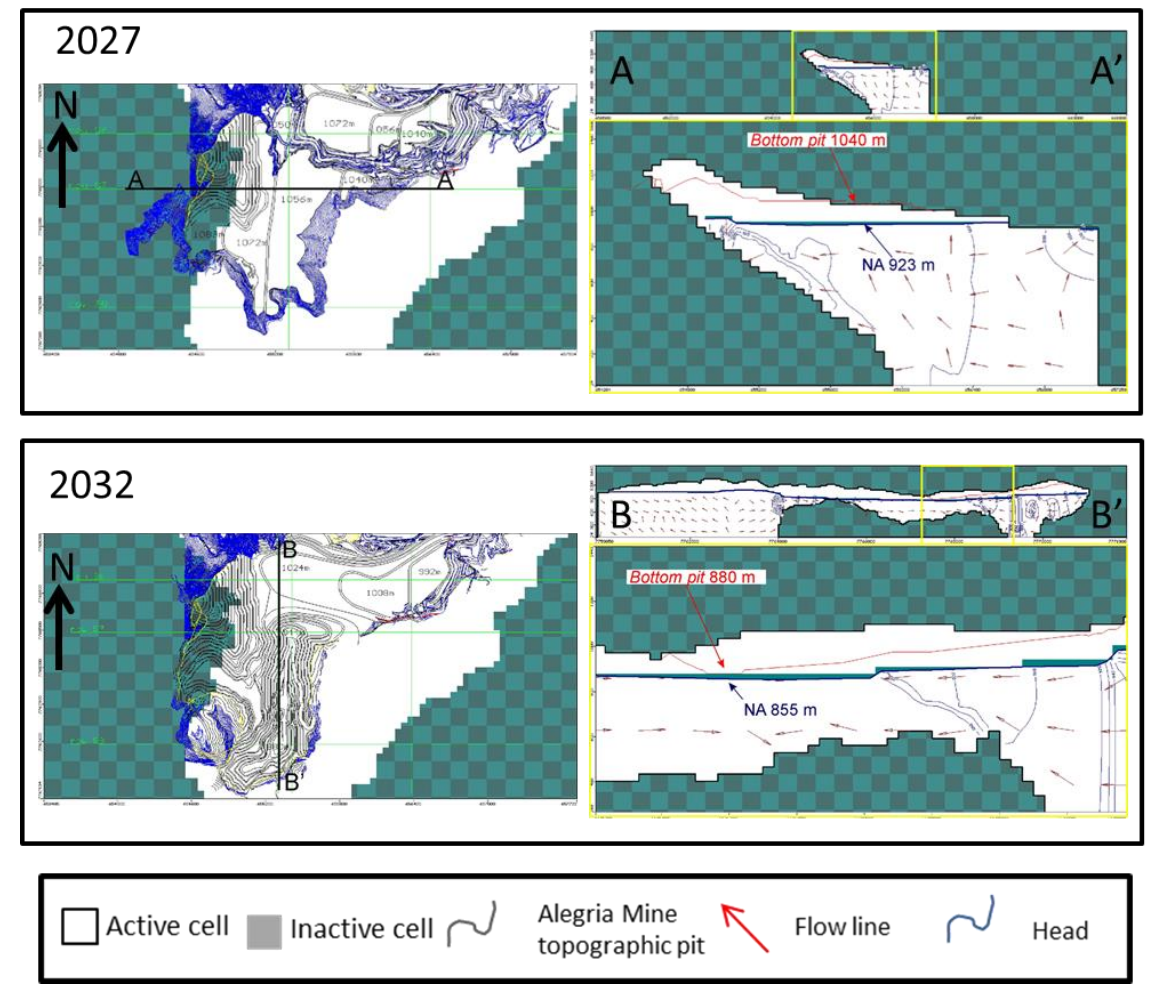

Figure 83 - Dewatering simulation for Alegria Center

At the beginning of dewatering simulation for Alegria South, where pit bottom already started at $1,008 \mathrm{~m}$ elevation, mine operations are planned to promote predominantly sideways expansion until 2019 in the north area, when the pit geometry intercepts groundwater level. In 2020, mine operation advances in depth in the north area to keep ore extraction. Pumping well implementation will be necessary to enable partial extraction of the ore reserves until 2019. The main results provided from the simulations were water table level and number of wells to dewatering, as presented in figures 84 and 85 . 

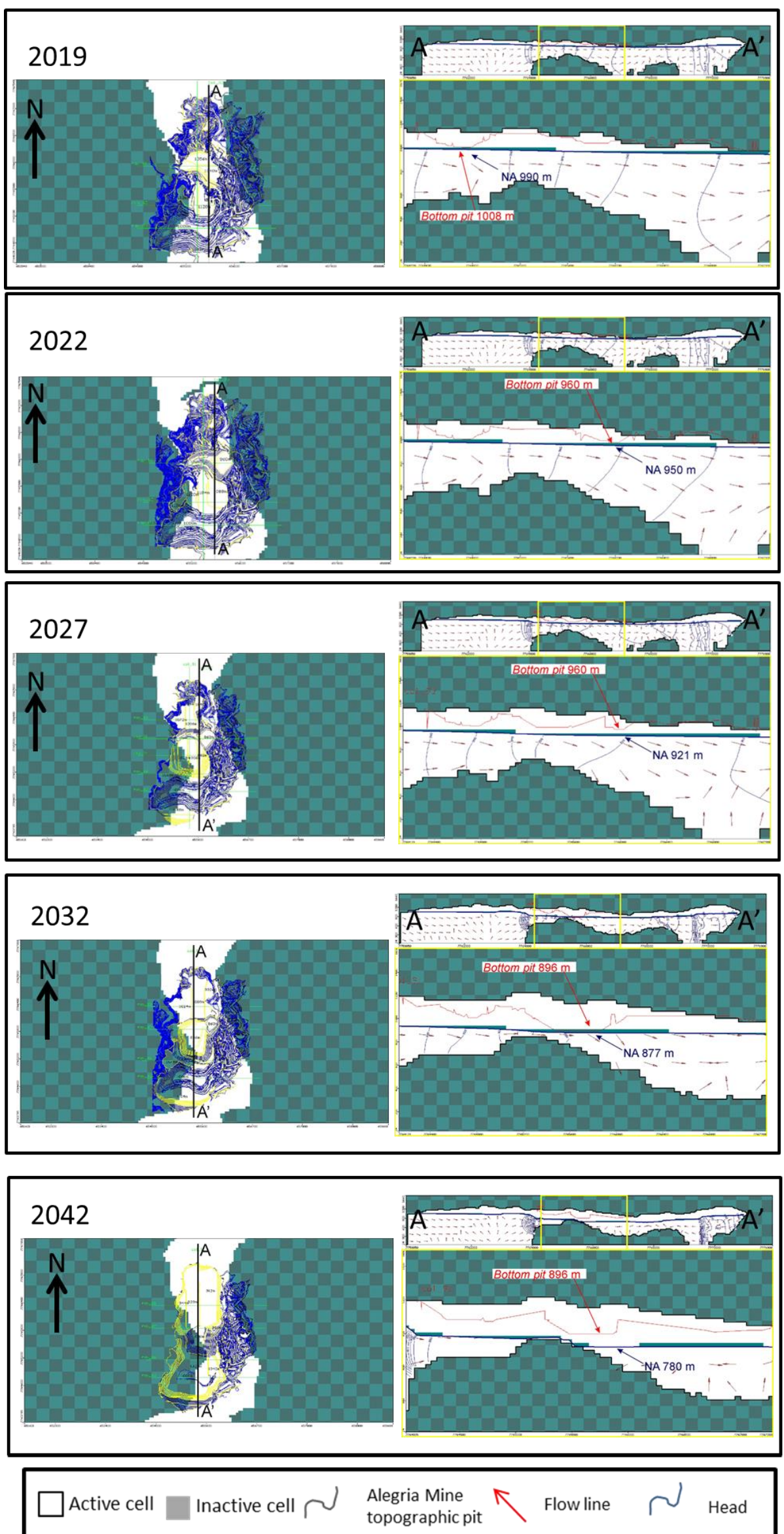

Figure 84 - Dewatering simulation for Alegria South. 


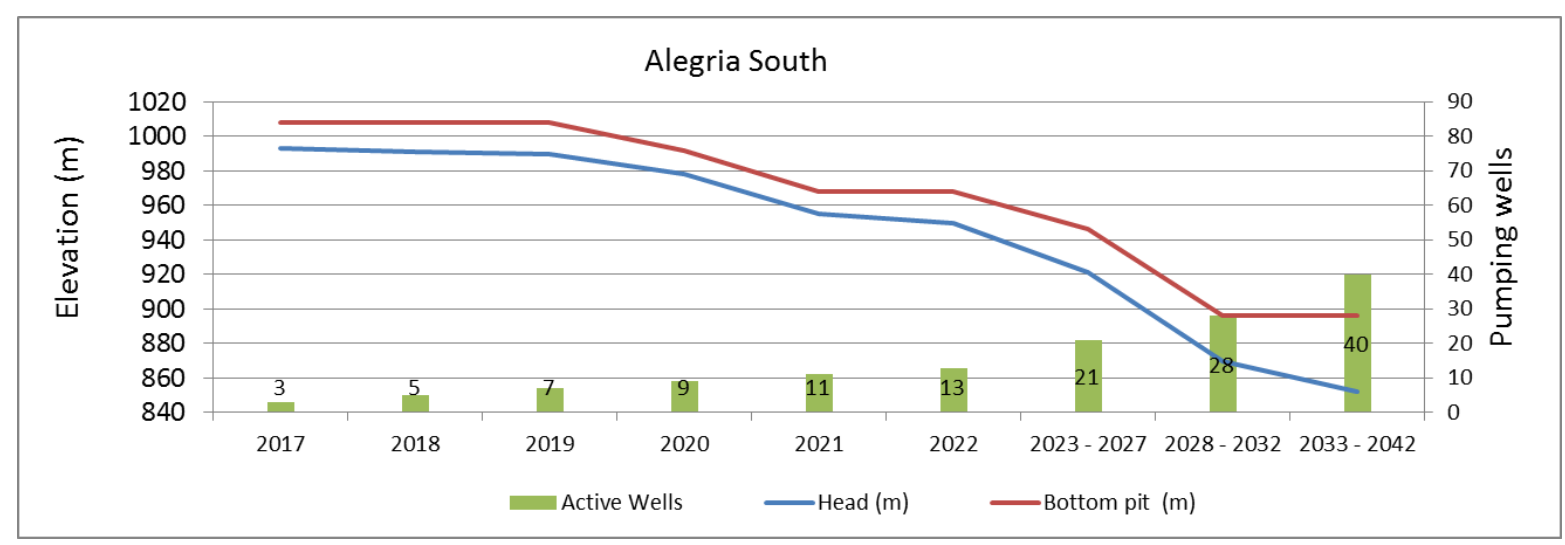

Figure 85 - Mine pit bottom elevation and drawdown level reached by pumping wells in Alegria South.

Figure 86 illustrates the water volumes to be pumped from aquifer to achieve Alegria Mine simulation dewatering for 25-years period. Figures 87 and 88 show the location of the pumping wells required to Alegria Mine dewatering, installed during the simulated period of 2016 to 2042.

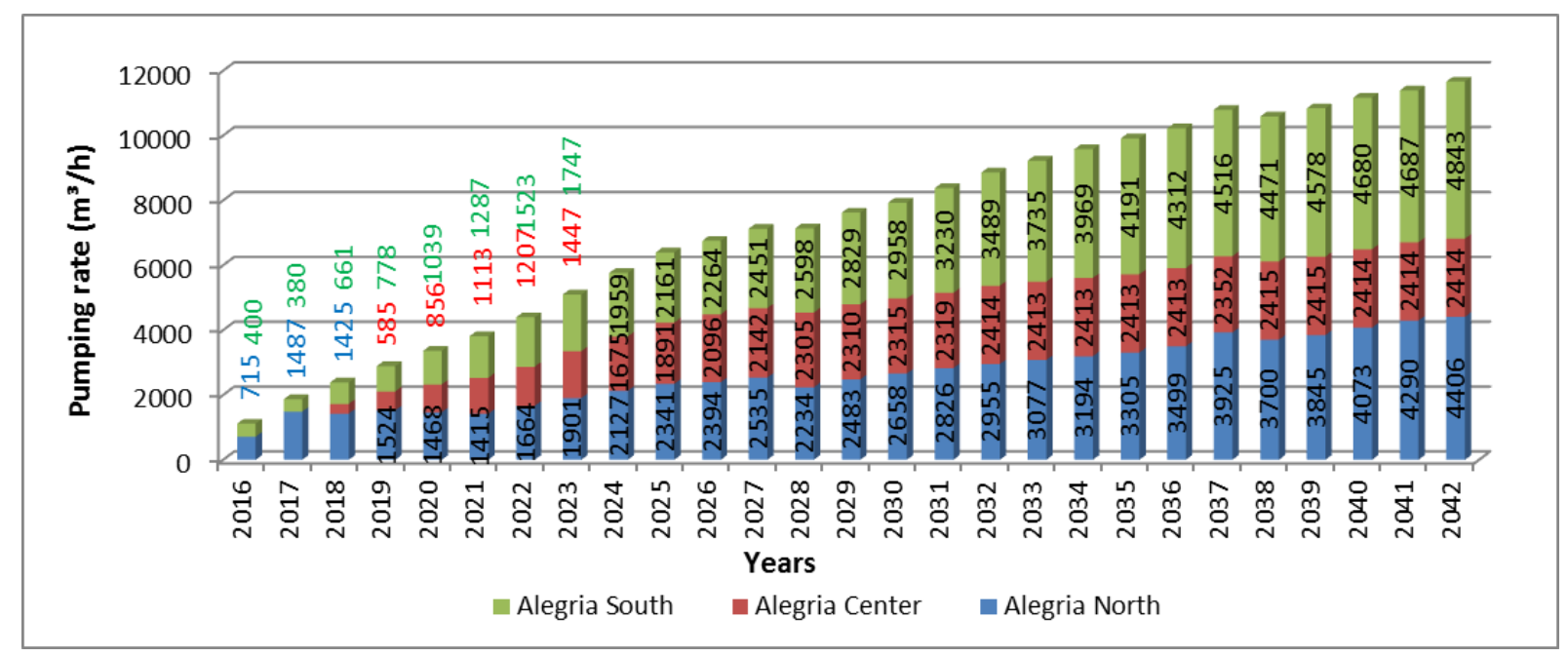

Figure 86 - Pumping rates over time in Alegria Mine. 


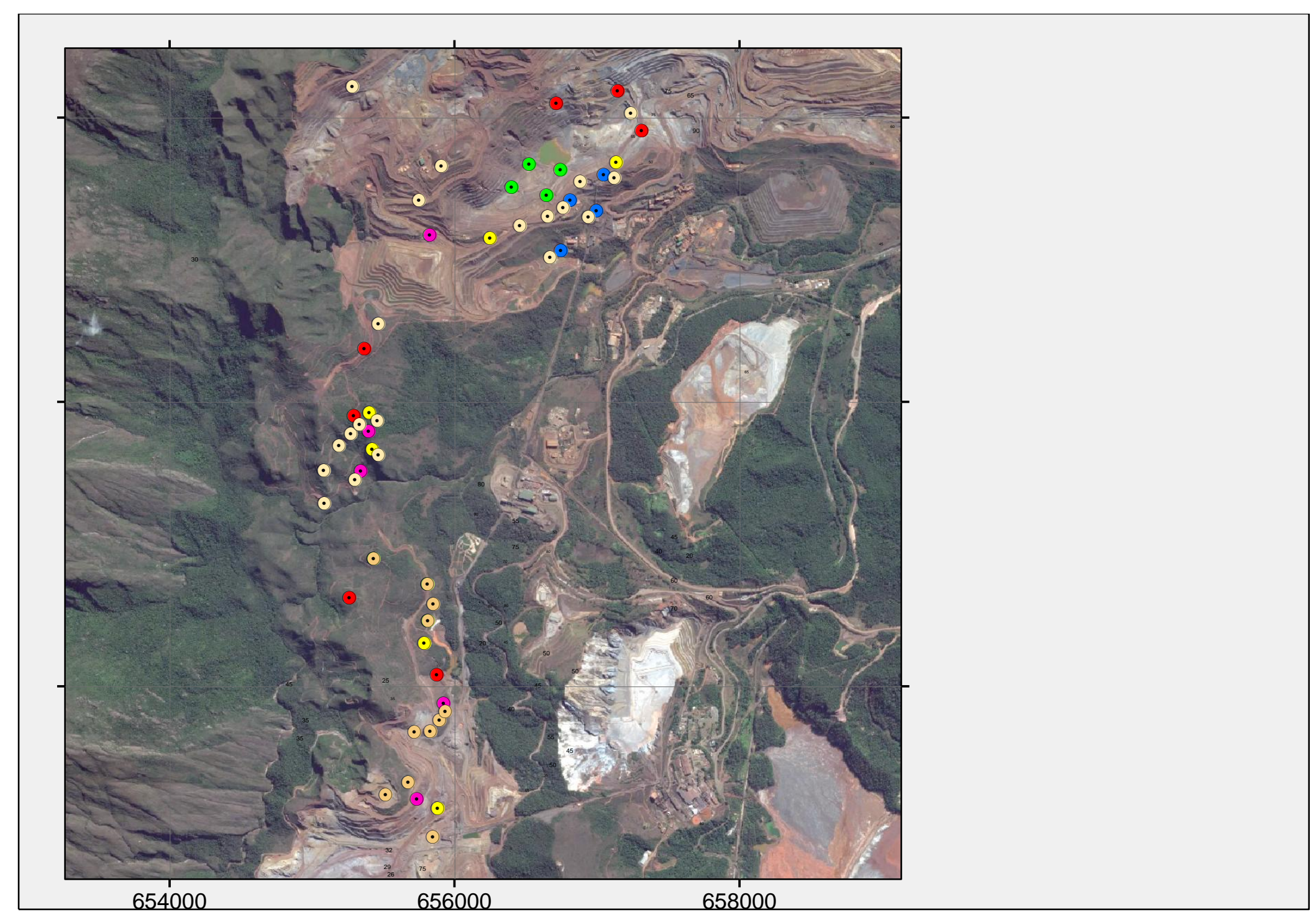

Figure 87 - Location map for pumping wells installed from 2017 to 2027. 


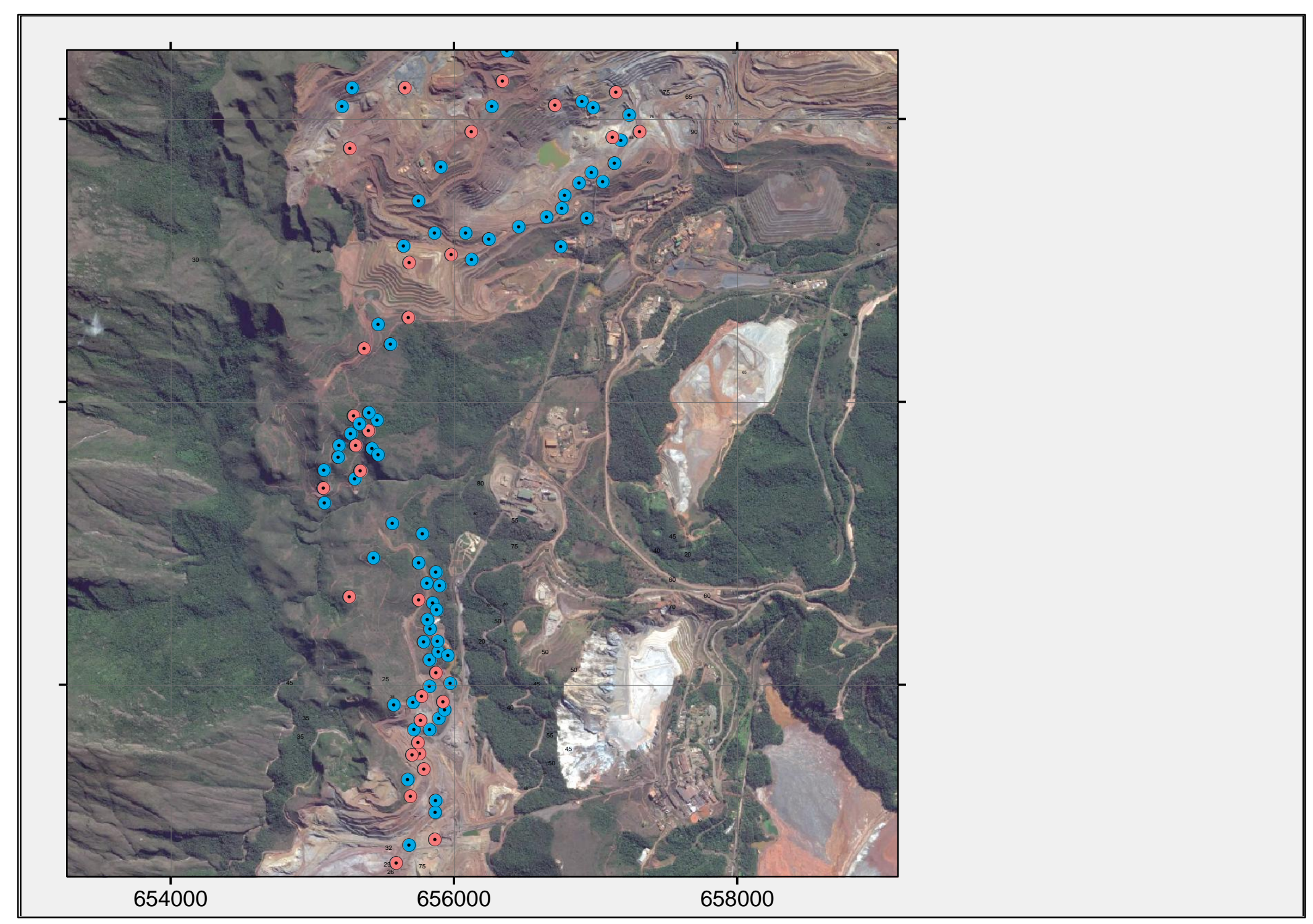

Figure 88 - Location map for pumping wells installed from 2028 to 2042. 


\section{Impacts Simulations}

In general, high pumping rates of groundwater for a long time can result in local impacts on availability of surface water bodies, such as reduction of rivers and creeks flow rates and drought of springs.

Due to the forecasted long period in this hyphotetic pumping in Alegria Mine, it is expected that some impacts will occur regionally, as the mine pits advance deeper into the ferriferous formation. In order to estimate potential effects that may occur to surface water resources in study area, base-flow rates of rivers and springs have been monitorated over time. Results were obtained based on transient model prepared for dewatering simulations.

Figure 89 displays study area compartimentation in sub-catchments considering individual creeks and springs, transcribed to numerical model. Base-flow reduction -on each of these superficial drainages was calculated as can be seen on figure 90 .

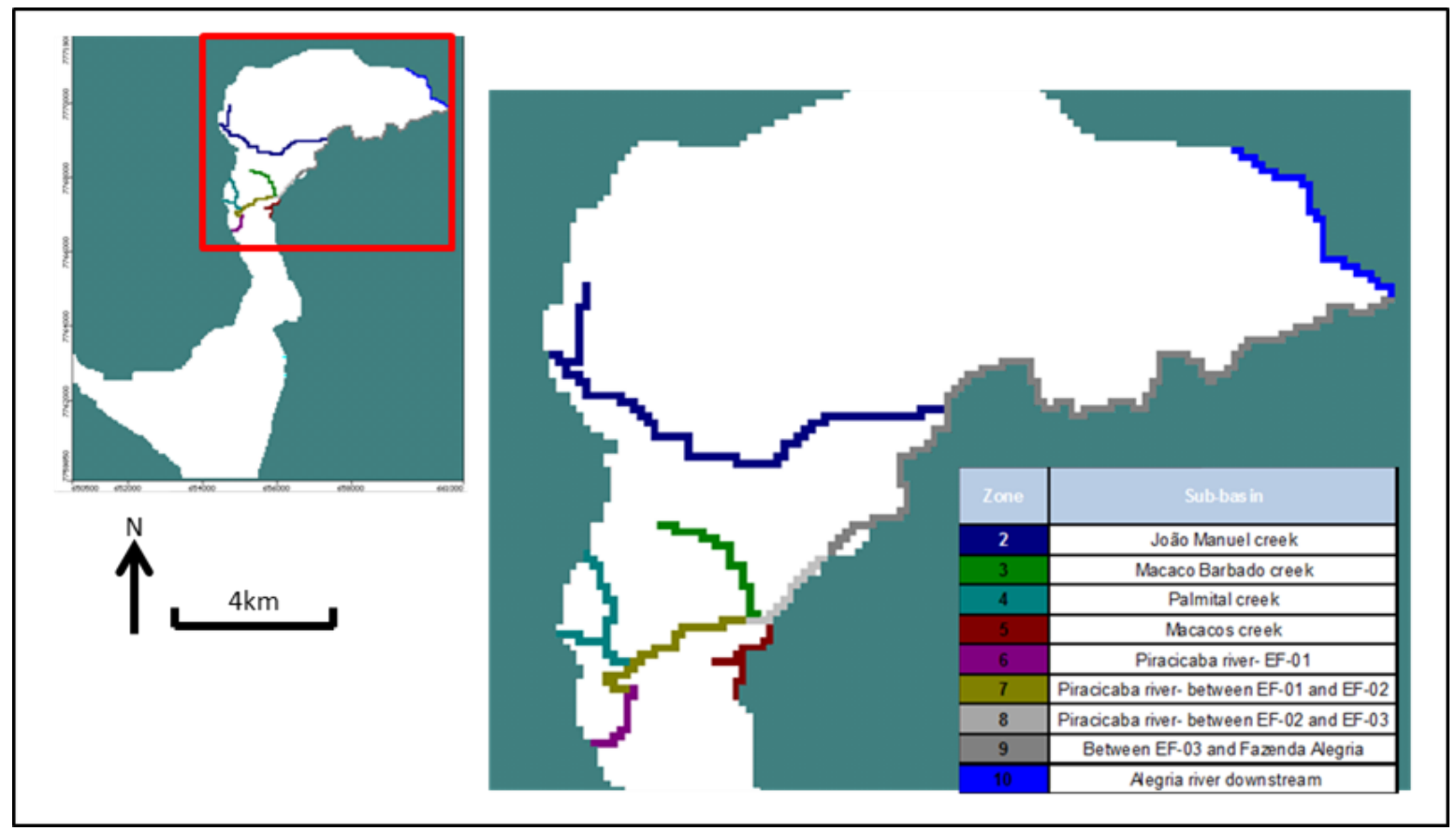

Figure 89 - Sub-catchments considered for base-flow monitoring

Simulation results indicate that base-flows of Piracicaba River and tributaries subject to Piracicaba River the area of influence of the Alegria Mine will significantly decline and, in some cases, even cease, except for Almas creek. However, it emphasizes that simulated impacts refer solely to segments of superficial water bodies flowing Piracicaba River over iron formation. 


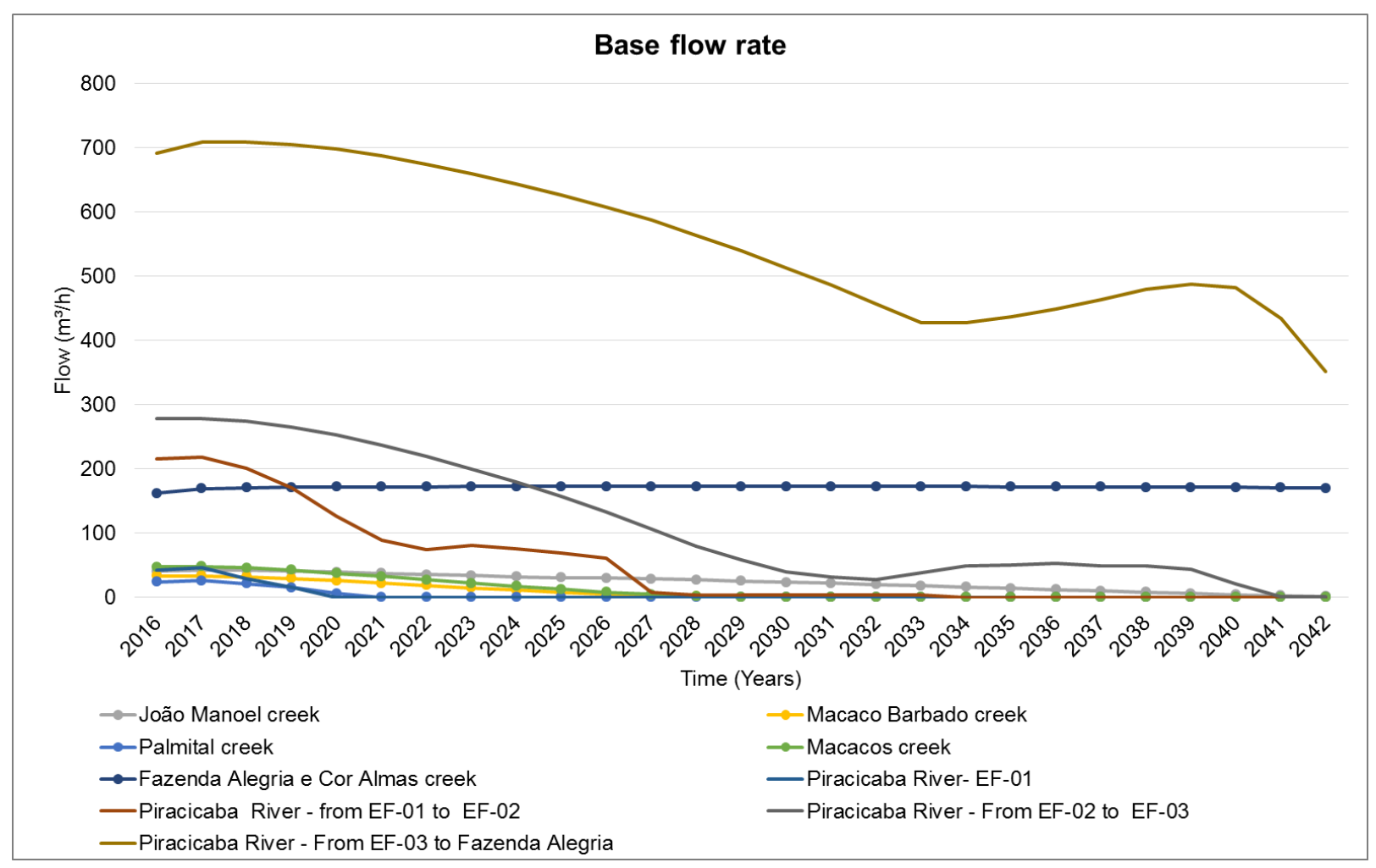

Figure 90 - Rivers and creeks baseflow reduction over time due to mine dewatering.

\subsection{Cut-off Wall}

A cut-off has been designed along the Piracicaba river to evaluate its capacity to keep base-flow rate in its both sides. This structure may have a hydraulic interception function, and it consists of a low permeability barrier built by a simple or reinforced concrete, bentonite slurries and polymers (POWERS et al, 2007). According to rock hardness and abrasiveness, especially in igneous and metamorphic rocks, cut-off wall construction can be quite complex. Normally cutoff construction is performed by excavation and drilling using special equipment, reaching depths between 3 and $50 \mathrm{~m}$.

Based on the transient model used to simulate Alegria Mine dewatering from 2017 to 2042 , cut-off walls $2 \mathrm{~m}$ thick and with hydraulic conductivity of $1.0 \times 10^{-8} \mathrm{~m} / \mathrm{s}$ were inserted using Wall (HFV) Boundary Conditions. This tool allows such features to be simulated without reducing grid spacing the model. During the remodel process, the wall face was inserted paralel to main Piracicaba River direction in both sides between Alegria South and Alegria Center (Figure 91). This river segment, monitored by two fluviometric stations, EF01 (upstream) and EF02 (downstream), has a $4^{\circ}$ slope that increases run-off gradient on Piracicaba River. Due to this characteristic, walls boundary conditions were inserted in two layers with different thickness (40 $\mathrm{m}$ thick for layer 19 and $50 \mathrm{~m}$ thick, for layer 20). 


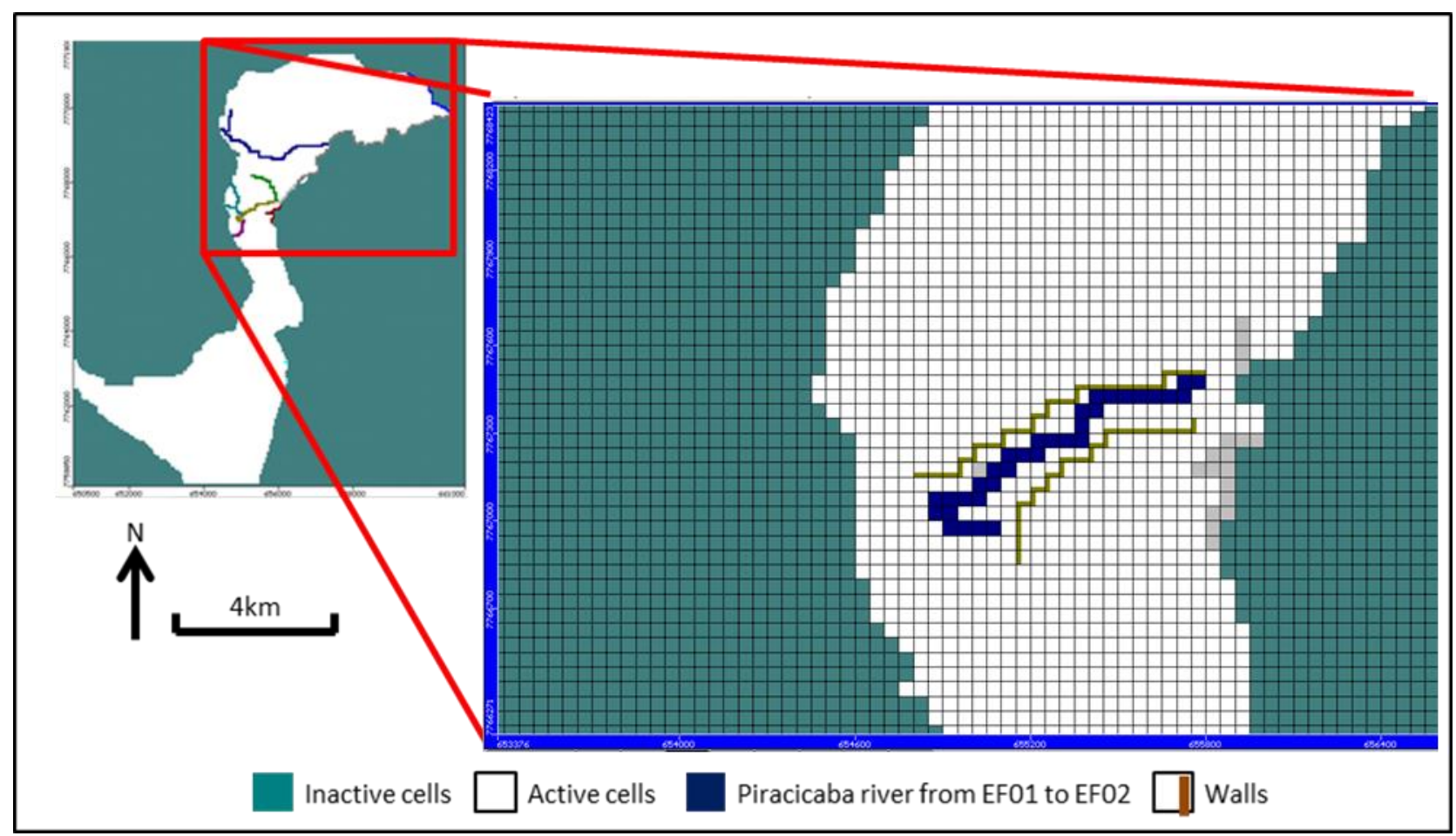

Figure 91 - Cut-off walls location along Piracicaba river (layer 20).

Cut-off simulation results show that flow lines that comprise discharge system of Piracicaba river segment are deep. In figure 92 (Steady State), before pumping starts in Alegria North and Alegria Center, one observes that river segment acts as an aquifer discharge zone. Simulations of the wells in operation have shown that equipotential surfaces change their positions over the years in response to the drawndown system. This situation occurs from 2019 to 2042 when new pumping wells are installed in Alegria North and Alegria Center.

Analysing baseflow reduction percentages, cut-off walls did not decreased leakage from Piracicaba river to aquifer on the segment between fluviometric stations (Figure 93). According to the hydraulic balance, river base-flow decreases in the same proportion as without cut-off wall application. 


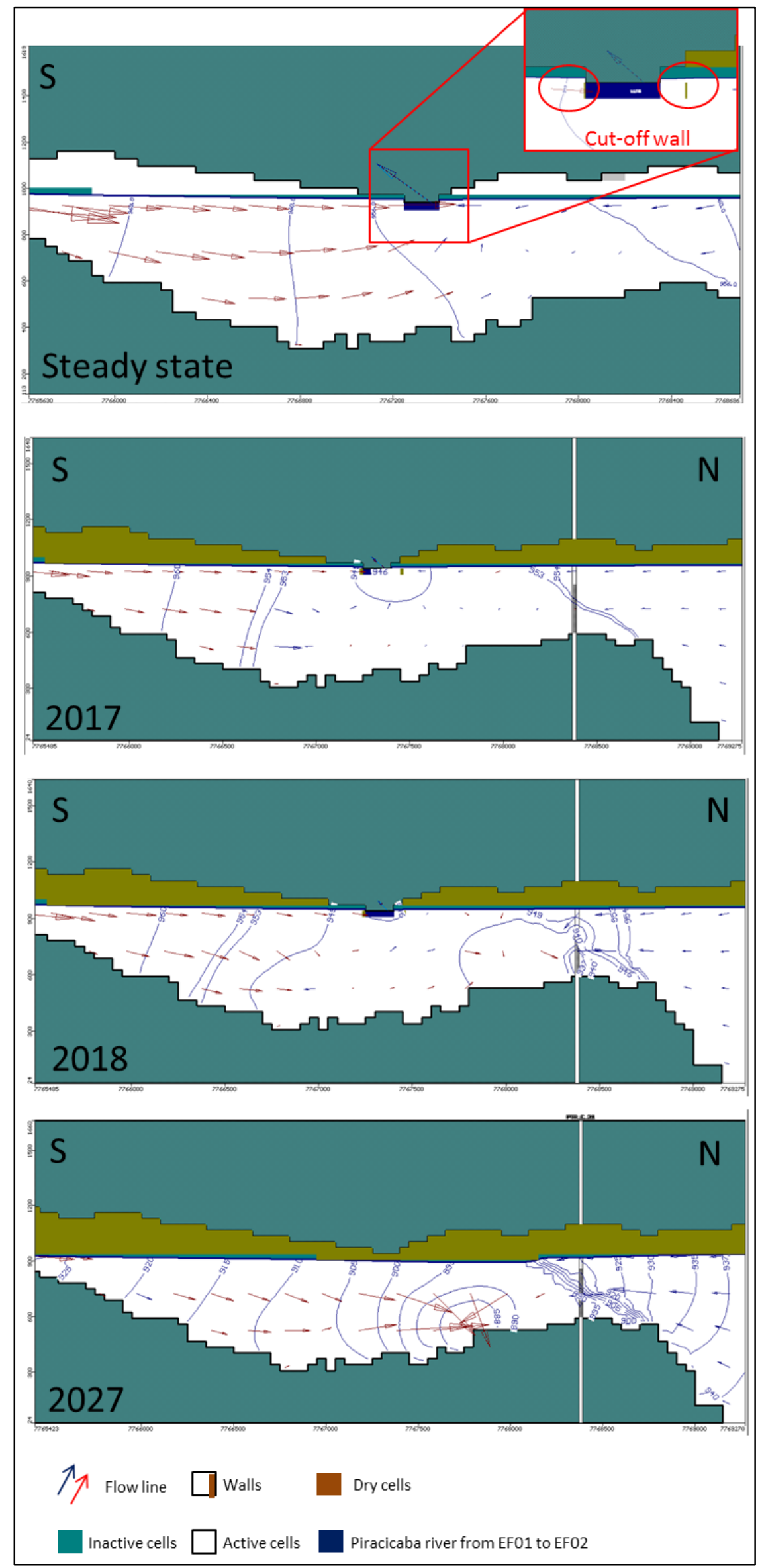

Figure 92- Drawdown simulation using cut-off walls on both sides of Piracicaba river (column 98) 


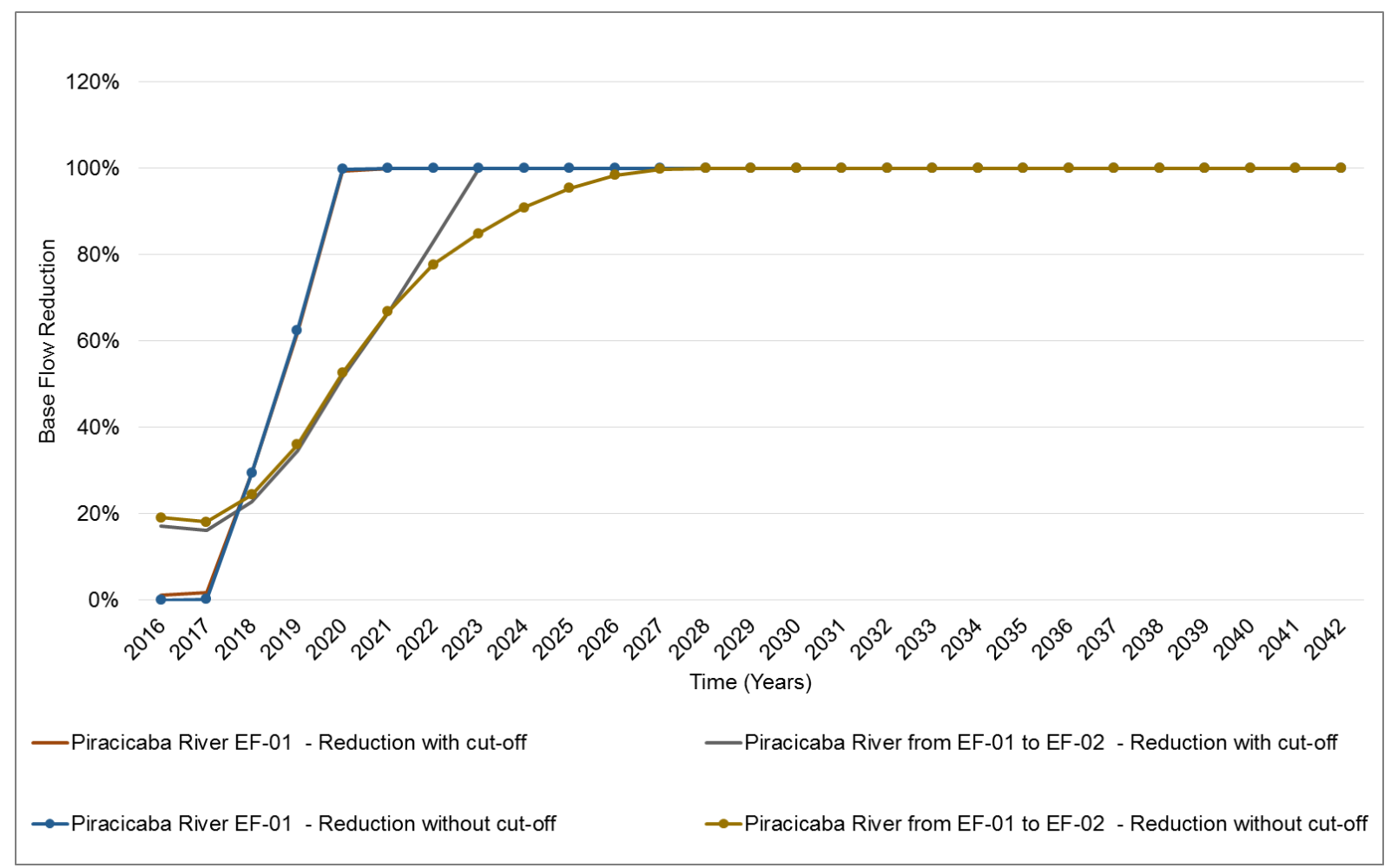

Figure 93- Baseflow reduction (\%) between fluviometric stations

\section{Conclusions}

A dewatering simulation model is crucial to support mine planning decisions. Mine planning projects and its expansion are very often conditioned to hydrogeological knowledge to develop groundwater drawdown and thus allowing access to ore reserves. The budged cost to promote mine dewatering is relative high and a pumping system implementation schedule can be planned using numeric groundwater flow simulation. Numerical simulations performed for Alegria Mine showed that a hyphotetic dewatering program should be executed by installing 96 pumping wells spread in entire mine to acess ore reserve below water table. Steady-state model was calibrated with normalized RMS errror of $4.68 \%$ and mass balance error of $0.001 \%$. Hydraulic conductivity calculated values showed a huge range from $2.0 \times 10^{-5} \mathrm{~m} / \mathrm{s}$ to $1.0 \times 10^{-8} \mathrm{~m} / \mathrm{s}$. Intrusive rocks and phyllites are impermeable barriers that condition the direction of groundwater flow. Results from the transient model calibrated for a 10 years pumping scenario refined the boundary conditions and hydraulic parameters of Cauê Aquifer. Specific yield calibrated values corresponded in average to $7 \%$, very close to the observed ones obtained by Chiste-Costa (in preparation, Chapter 6). To attend pit topography schedule to access ore reserves in the future, dewatering simulations through pumping wells installation were carried out from this simulated scenario. A total flow rate of $11,600 \mathrm{~m}^{3} / \mathrm{h}$ was estimated by operation of 98 pumping wells to achieve ore extraction goals. This study supports the general conclusion that numerical modeling should be considered to precede dewatering programs, reducing future financial expenses. 
Based on the dewatering transient model, cut-off simulations showed low efficiency to keep the natural surface water flow rates, mainly in Piracicaba River.

\section{Acknowledgements}

This work was support by Samarco Mineração SA. A special thanks for Waterloo Hydrogeologic support during this work.

\section{References}

Endo, I., Chemale, F. 1991 Projeto Sinclinal de Alegria aba NE. Convenio UFOP/Samitri, relatório interno, $13 p$

Endo, I., Fonseca, M. A. Sistema de cisalhamento Fundão-Cambotas no Quadrilátero Ferrífero, MG: geometria e cinemática. Revista Escola de Minas , v. 45, n. 1/2, p.15-17, 1992.

Freeze R.A., Cherry J.A., 1979: Groundwater. Prentice Hall Inc., NJ, USA.

GEOVIA, 2015, Software GEMS 6.7, 20Vancouver, B.C., Canada, V6E 3X1.

Guiguer, N., Thomas, F. Visual MODFLOW. Waterloo Hydrogeologic, Inc., Waterloo, Canada. 1998

Januzzi, A., Alkmin, F.F. 1989. Geologia estrutural da Mina de Alegria. Convenio UFOP/Samitri, Relatório interno. 32p.

Powers, J.P., Corwin, A.B., Schmall, P.C., Kaeck, W.E., Herridge, C.J., Morris, M.D., 2007: Construction Dewatering and Groundwater Control - New Methods and Aplications. 3를 Edição. USA.

Rosière, C.A., Chemale Jr., F., 2000: Brazilian iron formations and their geological setting. Revista Brasileira de Geociências, São Paulo, v. 36, n. 2, p. 274-278.

Veríssimo, C.U.V., 1999: Jazida de Alegria: Gênese e Tipologia dos Minérios de Ferro; Minas 3, 4 e 5 Porção Ocidental. 2vol. Tese de Doutorado. Rio Claro: Instituto de Geociências e Ciências Exatas da Universidade Estadual Paulista. 


\section{CHAPTER 8 - CONCLUSIONS AND RECOMMENDATIONS}

\section{Conclusions}

After all, the feasibility evaluation of expanding mine should be based on numeric simulations and hydrogeological knowledge of the study area. The budged cost to promote mine dewatering is relative high and a pumping system implementation schedule can be planned using numeric groundwater flow simulation.

To feasibility the iron ore extract in Alegria Mina below water table, it was necessary first to build a $3 d$ geological-typological model based in mineralogical/textural evolution. In addition of using the model for common activities of mine planning, geological-typological model is used as fundamental basis for hydrogeology studies. Some important applications and good results are being achieved by Samarco's team, due to very good correlations of the geological genesis and mineralogical features. Visualization of ore body geometry and major structures in the Alegria Mine allowed the subdivision into four geological domains: specularitic itabirite, martitic itabirite, indistrict itabirite and amphybolitic itabirite.

These domains in Alegria Mine correspond to Cauê aquifer, predominantly composed by diferents types of itabirites. Surrounded by phyllites and quartzites with low permeability, itabirites from Cauê Aquifer were grouped in three hydroestratigraphic units: Upper Aquifer, Intermediate Aquifer and Lower Aquifer. Accordind to pumping, slug and recovery tests in diferents itabirites, Upper Aquifer is composed mainly by specularitic itabirite with hydraulic conductivity values up to $10^{-5} \mathrm{~m} / \mathrm{s}$. The intermediate Aquifer is constituted by martitic itabirites with hydraulic conductivity in average $10^{-6} \mathrm{~m} / \mathrm{s}$ and Lower Aquifer basically composed by amphybolitic itabirites varing from $10^{-6}$ to $10^{-7} \mathrm{~m} / \mathrm{s}$.

Using a automatic monitoring system composed by metheorological station, fluviometric station and spillways, observation wells and pumping wells, some interpretations were done using hydrograms, isoieta and evapotranspiration data to estimate the effective recharge. In average effective recharge in Cauê Aquifer in Alegria Mine is $700 \mathrm{~mm} /$ year. Using the same instruments, it was possible to evaluate the boundary conditionals in Alegria Mine.

Using the conceptual hydrogeological model, numerical simulations performed for Alegria Mine showed that a dewatering program should be executed by installing 96 pumping wells spread in entire mine to acess ore reserve below water table. The steady-state and transient models were calibrated using the monitoring data and it allows to prepare in advance the pumping well drilling plan. In the same simulated dewatering model can be calculed more than $10,000 \mathrm{~m}^{3} / \mathrm{h}$ peak pumping rate. This simulation can also evaluate the impacts on the superficial drenage, due to the drawdown progress. 


\section{Recomendations}

The deterministic models, such as those carried out in the present study, do not indicate the uncertainty levels. This uncertainty can be a risk for the mining companies not to achieve the necessary dewatering program to acess the ore reserve, below the water table. Based on this premise, it is recommended to carry out a stochastic model to verify the degree of uncertainty and conduct qualitative and quantitative risk management as a strategic decision tool.

In addition to the stochastic models, conceptual and numerical models based on the geotechnical information of survey and mapping reports are recommended. In crystalline rocks, the degree of fracturing, alteration and cohesion can govern the flow of groundwater. 